
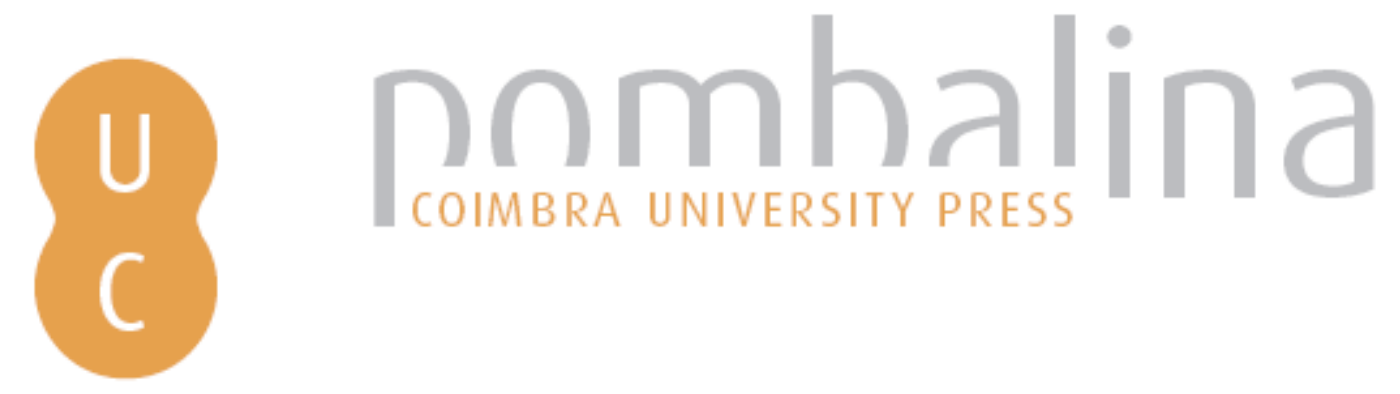

Oficinas de Muhipiti: planeamento estratégico, património, desenvolvimento

Autor(es): $\quad$ Rossa, Walter (org.); Lopes, Nuno (org.); Gonçalves, Nuno Simão (org.)

Publicado por: Imprensa da Universidade de Coimbra

URL

persistente: URI:http://hdl.handle.net/10316.2/44305

DOI: $\quad$ DOI:https://doi.org/10.14195/978-989-26-1556-1

Accessed : $\quad$ 14-Dec-2021 17:57:23

A navegação consulta e descarregamento dos títulos inseridos nas Bibliotecas Digitais UC Digitalis, UC Pombalina e UC Impactum, pressupõem a aceitação plena e sem reservas dos Termos e Condições de Uso destas Bibliotecas Digitais, disponíveis em https://digitalis.uc.pt/pt-pt/termos.

Conforme exposto nos referidos Termos e Condições de Uso, o descarregamento de títulos de acesso restrito requer uma licença válida de autorização devendo o utilizador aceder ao(s) documento(s) a partir de um endereço de IP da instituição detentora da supramencionada licença.

Ao utilizador é apenas permitido o descarregamento para uso pessoal, pelo que o emprego do(s) título(s) descarregado(s) para outro fim, designadamente comercial, carece de autorização do respetivo autor ou editor da obra.

Na medida em que todas as obras da UC Digitalis se encontram protegidas pelo Código do Direito de Autor e Direitos Conexos e demais legislação aplicável, toda a cópia, parcial ou total, deste documento, nos casos em que é legalmente admitida, deverá conter ou fazer-se acompanhar por este aviso. 


\section{OFICINAS DE \\ MUHIPITI \\ planeamento estratégico \\ património \\ desenvolvimento}

organização:

Walter Rossa

Nuno Lopes

Nuno Simão Gonçalves

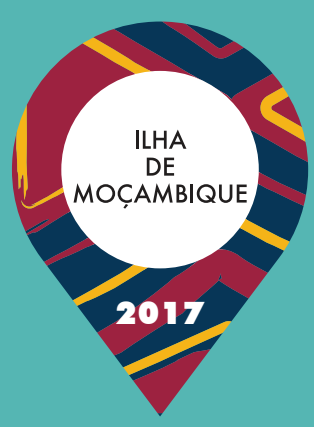


De 19 a 29 de julho de 2017, numa iniciativa conjunta das universidades de Lúrio e de Coimbra, teve lugar na llha de Moçambique o Oficinas de Muhipiti: planeamento estratégico, património, desenvolvimento. Decorrendo em ambiente académico com assumidos propósitos pedagógicos, teve como desafio estudar formas de potenciar o impacto da instalação da universidade na Ilha com a criação da nova Faculdade de Ciências Sociais e Humanas da Unilúrio, utilizando o seu património como ativo para o desenvolvimento sustentável e, assim, para o bem-estar dos seus habitantes.

O evento foi constituído por 6 oficinas integradas por estudantes de arquitetura e professores de várias áreas disciplinares de ambas as universidades, tendo cada uma de dar resposta ao desafio que lhe fora lançado. Na tarefa contaram com o contributo de especialistas convidados, dos agentes e instituições com ação na Ilha e, principalmente, da população.

Este livro e a exposição que com ele foi produzida, visam fixar e divulgar o processo e os resultados do Oficinas como algo que não só demonstra um futuro possível e desejável através do património, mas também testemunhar o compromisso recente da universidade com a Ilha. 
O L H A R E S 


\section{TÍTULO DO LIVRO}

Oficinas de Muhipiti: planeamento estratégico, património, desenvolvimento

\section{EDIÇÃO}

Imprensa da Universidade de Coimbra

Email: imprensa@uc.pt | URL: http://www.uc.pt/imprensa_uc

Vendas online: http://livrariadaimprensa.uc.pt

\section{PRODUÇÃO}

Cátedra UNESCO Diálogo Intercultural em Patrimónios de Influência Portuguesa http://www.patrimonios.pt

\section{ORGANIZAÇÃO}

Walter Rossa, Nuno Lopes, Nuno Simão Gonçalves

\section{AUTORES}

Aldevina Brito, António de Amurane, Bernardo Xavier, Fernando Pires, Francisco Noa, Helena Soares Rebelo, Isequiel Alcolete, Jaime Aguacheiro, Jens Hougaard, João Vaz, Júlio Carrilho, Luís Lage, Lisandra Franco de Mendonça, Luísa Trindade, Margarida Relvão Calmeiro, Milton Novela, Momade Ali, Nuno Lopes, Nuno Simão Gonçalves, Renata de Araujo, Solange Macamo, Valdemiro Aboo, Victor Mestre, Walter Rossa

\section{REVISÃO}

Graça Pericão (versão original do texto), Nuno Lopes (sobre maquetas)

\section{DESIGN}

Helena Soares Rebelo

\section{INFOGRAFIA}

Helena Soares Rebelo e Nuno Simão Gonçalves

EXECUÇÃO GRÁFICA Diário do Minho

ISBN 978-989-26-1555-4

ISBN DIGITAL 978-989-26-1556-1

DOI https://doi.org/10.14195/978-989-26-1556-1

DEPÓSITO LEGAL 442098/18

(C) 2018, IMPRENSA DA UNIVERSIDADE DE COIMBRA 


\section{OFICINAS DE \\ MUHIPITI \\ planeamento estratégico \\ património \\ desenvolvimento}

organização:

Walter Rossa

Nuno Lopes

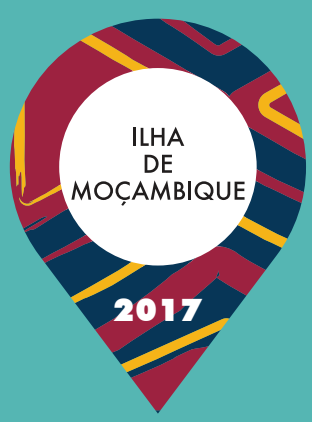

Nuno Simão Gonçalves 


\section{APOIOS}




\section{AGRADECIMENTOS}

- Autores e alunos

- Camões, Instituto da Cooperação e da Língua, IP

- Fundação Calouste Gulbenkian

- União das Cidades Capitais de Língua Portuguesa

- Instituto de Investigação Interdisciplinar da Universidade de Coimbra

- Centro de Estudos Sociais da Universidade de Coimbra

- Departamento de Arquitetura da Faculdade de Ciências e Tecnologia da Universidade de Coimbra

- Faculdade de Arquitetura e Planeamento Físico da Universidade Lúrio

- Jens Hougaard

- Carlos Brito

- Vasco Ribeiro

- António Giquira (Gito)

- Maria João Padez de Castro

- Carlos Costa

- Margarida Calafate Ribeiro e Miguel Bandeira Jerónimo 


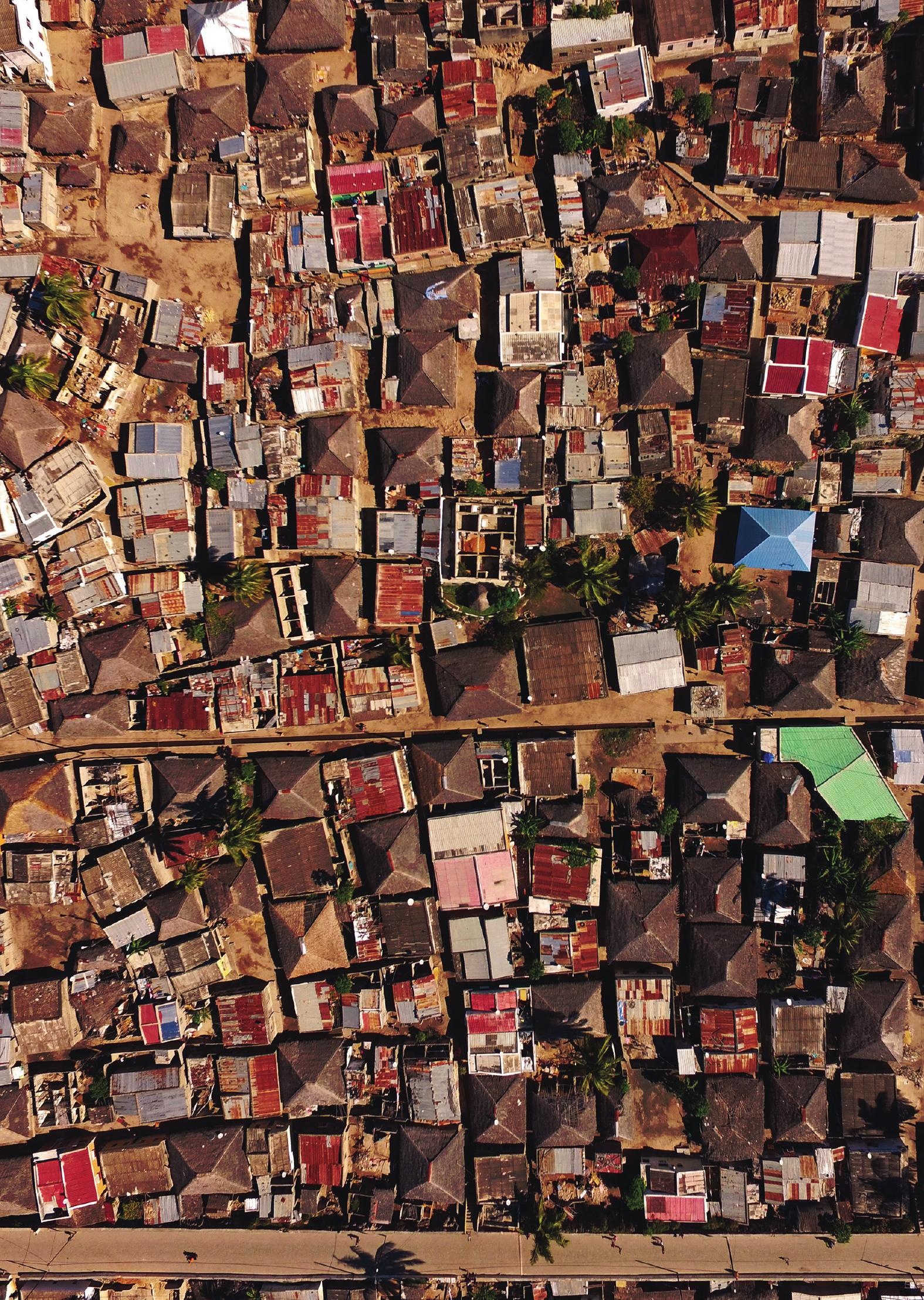


11 | UM LIVRO DE CRUZAMENTOS, verde

Walter Rossa, Nuno Lopes e Nuno Simão Gonçalves

17 | AS OFICINAS DE MUHIPITI E A UNILÚRIO

Francisco Noa e Isequiel Alcolete

\section{Oficinas}

[caminhos]

\section{INTRODUÇÃO | 51}

Walter Rossa

\section{ESTRATÉGIAS PARA O DESENVOLVIMENTO SUSTENTADO | 67}

Margarida Relvão Calmeiro e Valdemiro Aboo

ESPAÇO PÚBLICO | 107

António de Amurane e Fernando Pires

PLANO DIRETOR DA REFUNCIONALIZAÇÃO DA FORTALEZA | 123

Jaime Aguacheiro e Nuno Lopes

PLANO PARA CENTRO COMUNITÁRIO NA FAIXA CENTRAL DA ILHA| 155

Aldevina Brito e Lisandra Franco de Mendonça

CASAS DE MACUTI | 171

Bernardo Xavier e Victor Mestre

CENTRO DE INTERPRETAÇÃO DE MUHIPITI | 219

Luísa Trindade, Milton Novela e Renata de Araujo

MARCA-LUGAR MUHIPITI| 233

Helena Soares Rebelo e Nuno Simão Gonçalves 


\section{Muhipiti}

[perspetivas]

\section{5 | SOBRE A PRESERVAÇÃO}

DO PATRIMÓNIO CULTURAL EDIFICADO EM MOÇAMBIQUE Júlio Carrilho e Luís Lage

89 | O SISTEMA DE GESTÃO DA ILHA DE MOÇAMBIQUE:

IMPLEMENTAÇÃO DA LEGISLAÇÃO

NA ÁREA DO PATRIMÓNIO EDIFICADO

Solange Macamo

137 | ILHA DE MOÇAMBIQUE: GERIR O QUÊ E COMO?

UMA LEITURA DO PATRIMÓNIO

HISTÓRICO, CULTURAL E EDIFICADO

Jens Hougaard

193 | ILHA DE MOÇAMBIQUE: PERFIL SOCIOLÓGICO

Momade Ali

205 | ILHA DE MOÇAMBIQUE SALUBRE E FRESCA

EM TEMPO DE ALTERAÇÕES CLIMÁTICAS

João Vaz

ÍNDICE DE IMAGENS | 257

NOTAS BIOGRÁFICAS | 267

EXPOSIÇÃO | 273

DOCUMENTÁRIO | 279 


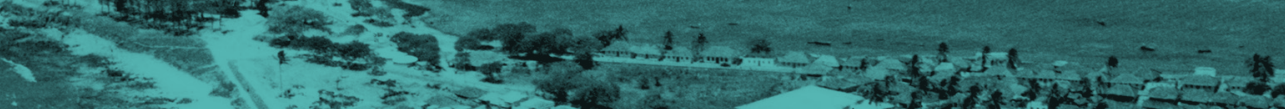

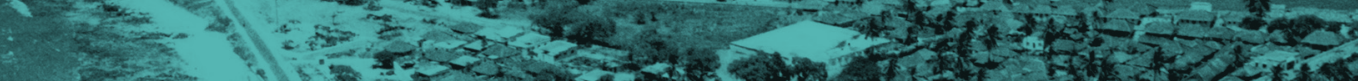

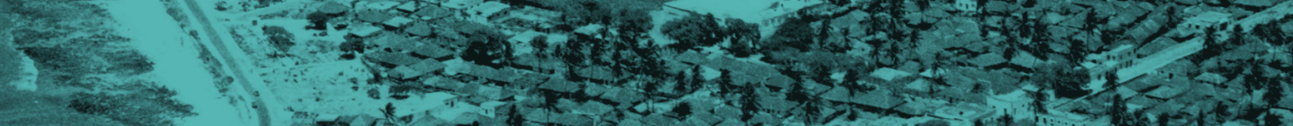

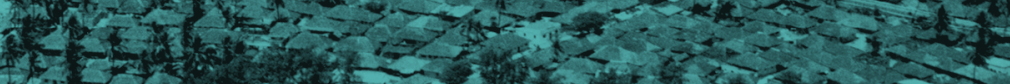

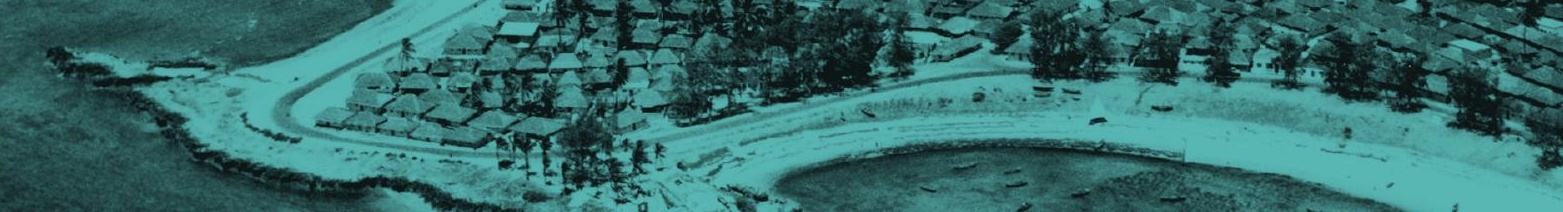

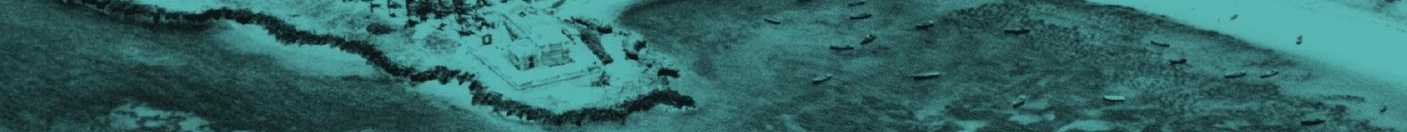

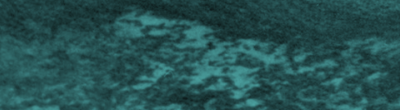

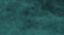

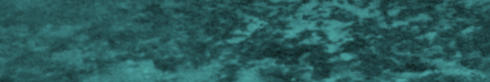

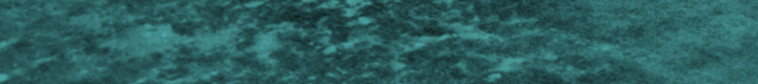

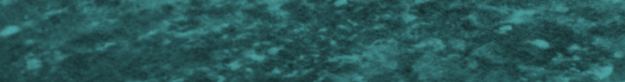

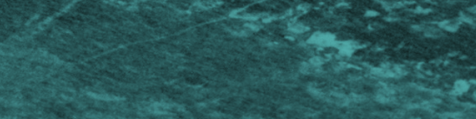

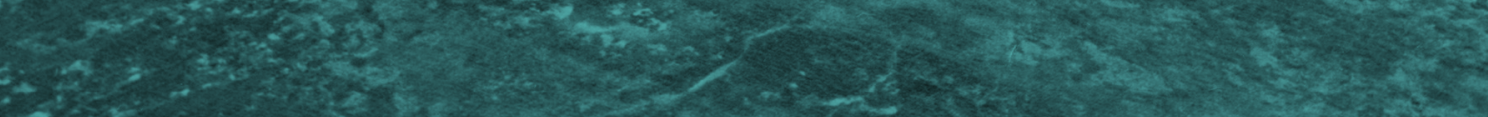

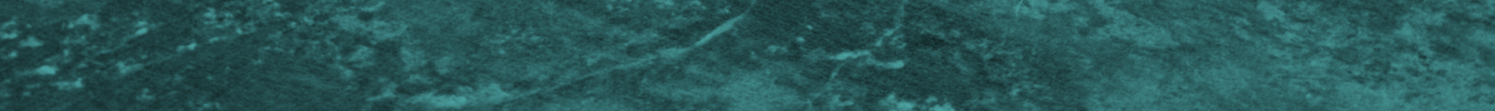

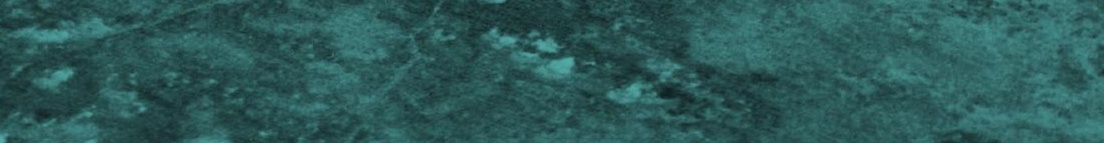




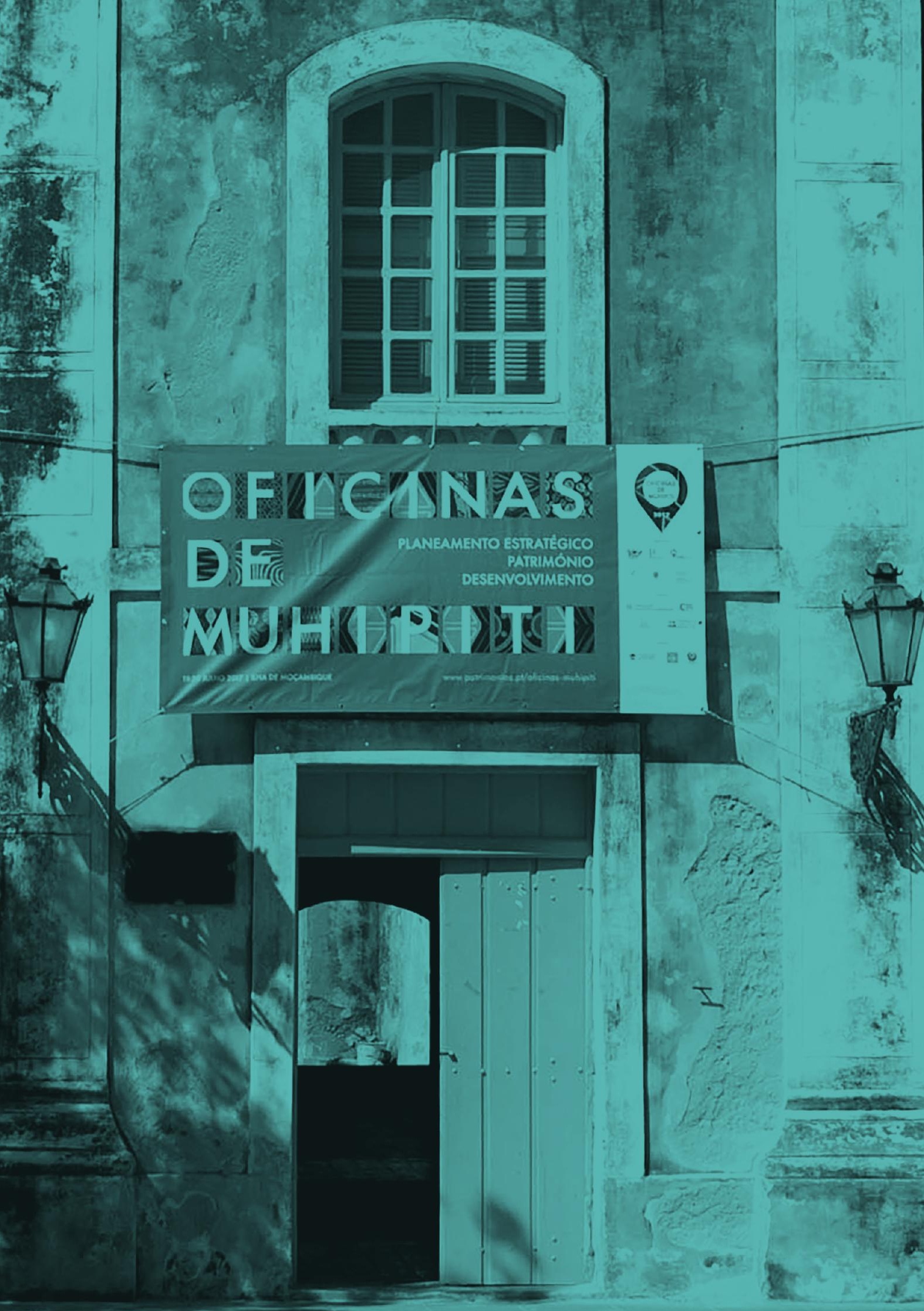




\title{
UM LIVRO DE CRUZAMENTOS, verde
}

\author{
Walter Rossa \\ Nuno Lopes \\ Nuno Simão Gonçalves
}

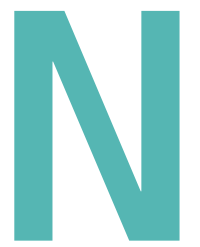

a esteira de inúmeros contributos para

o conhecimento e salvaguarda da Ilha de Moçambique, de que ganharam estatuto familiar um livro azul (1985) e um livro amarelo (2012), este livro verde regista e visa difundir os principais aspetos e resultados do evento que as universidades de Lúrio e de Coimbra levaram a cabo na Ilha de Moçambique, entre os dias 19 e 29 de julho de 2017, intitulado Oficinas de Muhipiti: planeamento estratégico, património, desenvolvimento. Muhipiti é o nome em língua Macua para a Ilha, bem inscrito desde 1991 na Lista do Património Mundial da UNESCO. A edição do livro cruza-se com a exposição de cartazes homónima, concebidos de forma a surgirem como um conjunto sem, contudo, pôr em causa as respetivas autonomias. Competiu-nos conduzir esses dois processos editorais, que só por isso aqui apresentamos, não se devendo iludir o facto de a produção do evento ter também estado a cargo dos colegas da UniLúrio, a quem desde logo agradecemos na pessoa do inexcedível Diretor da Faculdade de Arquitetura e Planeamento Físico, Isequiel Alcolete. 


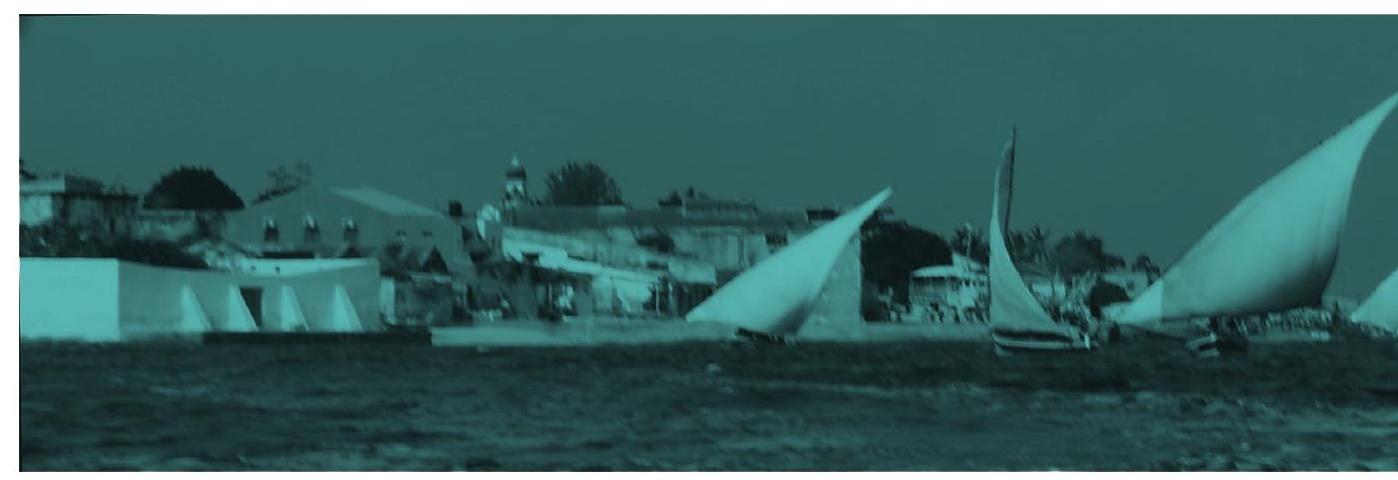

A ação foi espoletada pelo desafio que o Reitor da Universidade Lúrio lançou, em setembro de 2016, aos então coordenadores do projeto e curso de doutoramento Patrimónios de Influência Portuguesa da Universidade de Coimbra para, de forma cruzada, pensarem como potenciar a instalação, em curso, da universidade na llha com a criação da Faculdade de Ciências Sociais e Humanas, em prol da preservação do seu património e bem-estar dos seus habitantes. A ideia rapidamente evoluiu para o estabelecimento de uma discussão com os colegas da Universidade Lúrio com vista à definição e implementação dinâmicas e integradas de um modelo de desenvolvimento sustentável, através da preservação dos seus bens e valores patrimoniais, o que acabou por levar a um compromisso de cooperação académica também de intercâmbio docente e formação avançada.

A llha tem vindo a contar com múltiplas cruzadas nacionais e internacionais para a preservação do seu património, das quais há resultados nem sempre fáceis de percecionar, pois o desejo tem sido superior à capacidade de realização e o sucesso de uma ação setorial não sobrevive à inação nos demais setores. Numa perspetiva em macro escala, externa, comparativa e de tempo longo, muito se tem perdido ou degradado no quarto de século decorrido desde o reconhecimento do valor excecional da Ilha pela UNESCO. Porém, o essencial permanece, sendo inegável o crescimento de uma consciência geral do seu valor e do potencial que tem para uma melhoria das condições de vida dos seus atores quotidianos. Foi com esse entendimento que, entre outras coisas, nos pareceu essencial alertar para a necessidade de se estudarem, definirem e implementarem diversas ações de forma cruzada, na sua maioria relativamente simples e exigindo poucos recursos, cuja resultante seja mais do que a soma das respetivas partes, 


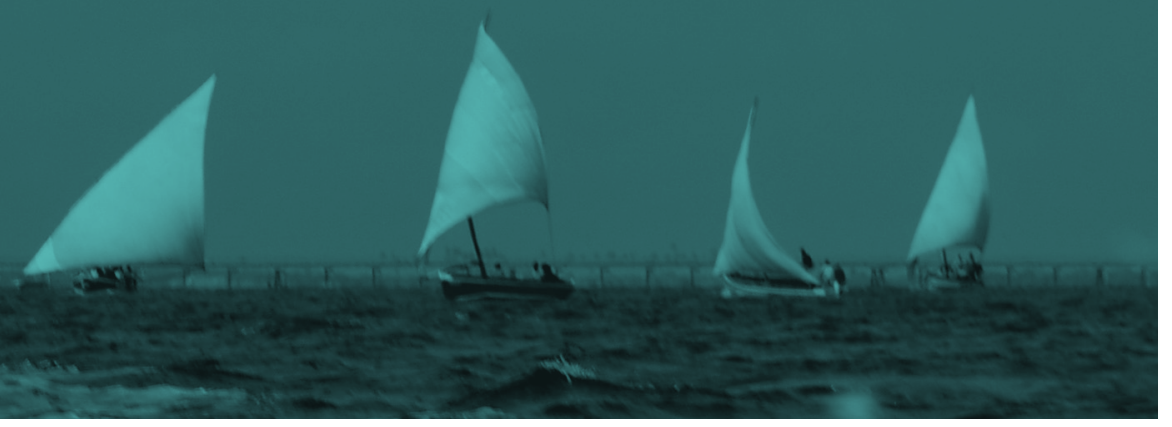

gerando-se, assim, uma dinâmica irreversível no médio e longo prazos. Por outras palavras, discutir e disseminar o potencial metodológico que políticas de ação estratégica têm para concretizar o que todos querem para a llha. Não temos dúvidas de que isso tem vindo a ser proposto - basta ver o que tem sido feito no âmbito do Cluster da Cooperação Portuguesa da Ilha de Moçambique (Camões e UCCLA) —, mas entendemos que a instalação da UniLúrio na Ilha é um dado novo com um extraordinário potencial estratégico, ou seja, suscetível de alavancar a definição e implementação, finalmente, de um modelo de desenvolvimento.

Tal como a preparação, funcionamento e orgânica do evento, tudo isso surge convenientemente explicado nas páginas que se seguem. Devemos, porém, realçar que o que esteve em causa e que agora é o objetivo central deste livro, consiste num contributo e ação serenos dentro do espaço da academia, com a projeção para o exterior que os agentes com responsabilidades de gestão territorial, política e cultural da Ilha entendam apropriada, e nunca um movimento com vista à sua substituição. Aconteceu, por exemplo, pouco depois, com o convite feito à Faculdade de Arquitetura e Planeamento Físico da Universidade Lúrio para integrar a equipa responsável pela elaboração do Plano de Conservação e Gestão da Ilha de Moçambique 2018-2022, o que tem vindo a fazer com grande diligência e adquire especial significado, se tivermos em conta que não participou na elaboração do Regulamento de Classificação e Gestão do Património Construído e Paisagem Ilha de Moçambique, aprovado em 2016, e do Catálogo do Património Construído Classificado da Ilha de Moçambique que o acompanha. Em suma, compete à academia investigar e disponibilizar-se para informar as políticas, não defini-las. 
Esse princípio teve expressão central na orgânica do evento, no qual se procurou, por todos os meios, recolher informação, opinião e envolver o maior número possível de todos quantos contribuem ou contribuíram para a preservação patrimonial da Ilha, desde logo no processo de permanente interação com a UNESCO. E vem, assim, muito a propósito agradecer e prestar homenagem a Jens Hougard, Júlio Carrilho, Luís Lage e Solange Macamo, que mais uma vez não se fizeram rogados em se cruzarem connosco no Oficinas e neste livro. Foi também com base nesses princípios que fomos construindo a base de dados sobre a llha com que informamos os participantes no evento - e que, esperamos, o Centro de Estudos e Documentação da Ilha de Moçambique [CEDIM] venha a disponibilizar em linha —; que fizemos múltiplas visitas e entrevistas aos habitantes, agentes e instituições políticas e culturais; que promovemos os debates públicos, muito participados, sobre os trabalhos em curso; que abrimos a exposição provisória dos resultados e a grande festa final que foi a regata de dhows. Em suma, procurou-se fazer um evento da universidade em cruzamento com as pessoas e não apenas para as pessoas.

A exposição e este livro, que agora passam a ser a ata definitiva dos resultados do Oficinas, procuram refletir tudo isso. Por isso o imaginámos com o ritmo, a cor e a vida do evento, desde logo estruturando-o com base nas suas duas componentes essenciais: Muhipiti [perspetivas] - 0 conjunto de conferências proferidas, que individualizamos num papel verde e impressão monocromática; Oficinas [caminhos] — os resultados dos trabalhos desenvolvidos pelas oficinas, em papel branco e impressão a cores. Todavia, simbolicamente e não só, pareceu-nos ainda que tudo isso deveria ser composto por forma a exprimir a simbiose perfeita que, por mérito de todos, foi atingida durante os trabalhos, pelo que ambas as partes surgem sucessivamente cruzadas. É um livro não meramente composto, mas desenhado, que se desejou tão alegre quanto sério.

É um livro que dedicamos aos 50 colegas de várias origens e estatutos que trabalharam no Oficinas, que também o fizeram e que, connosco, o oferecem à comunidade de Muhipiti, com quem para sempre estarão juntos. 


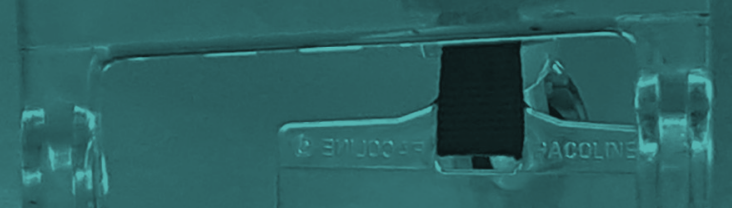

r

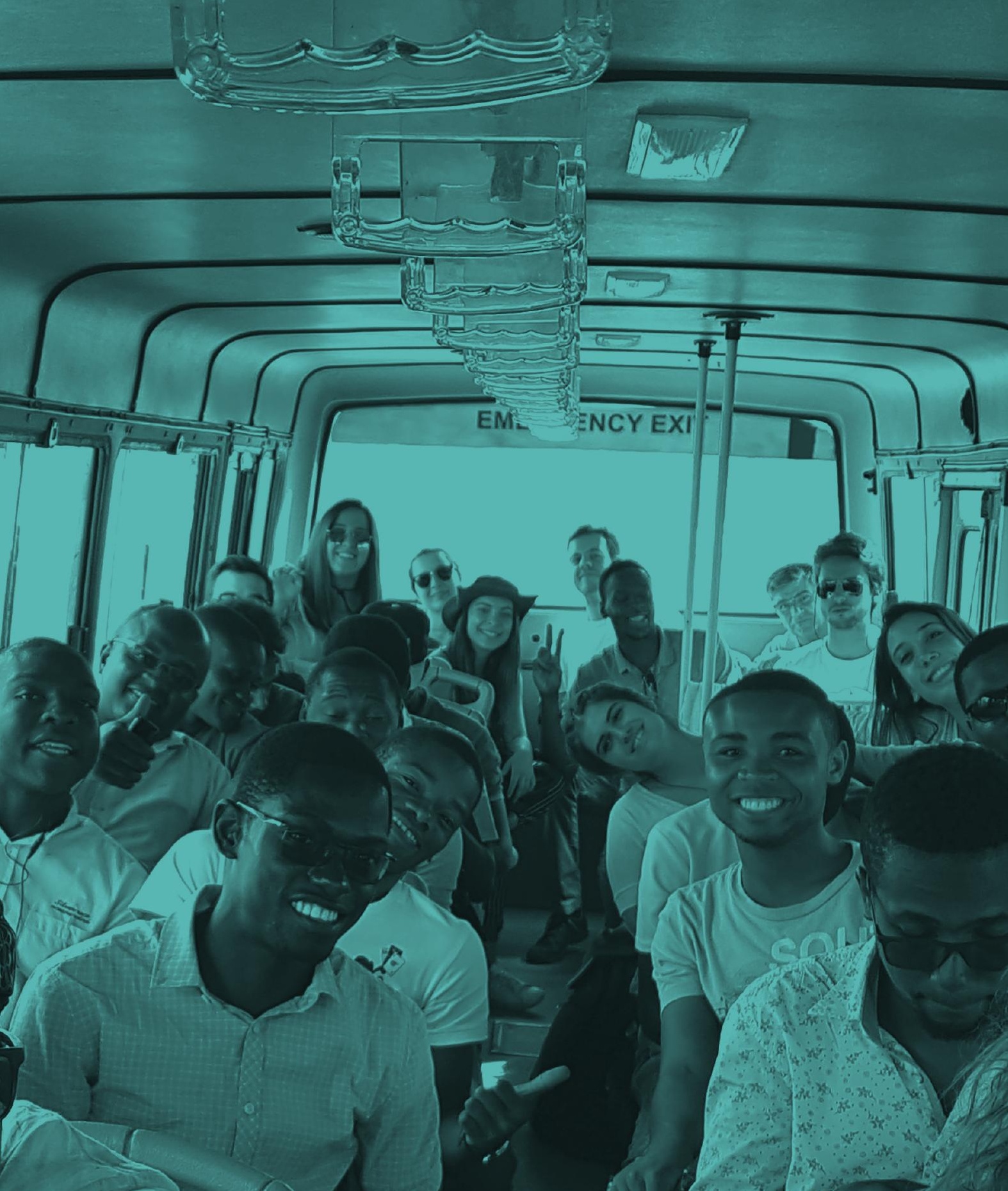





\section{AS OFICINAS DE MUHIPITI E A UNILÚRIO}

Francisco Noa

Reitor da Universidade Lúrio

Isequiel Alcolete

Diretor da Faculdade de Arquitetura e Planeamento Físico da Universidade Lúrio

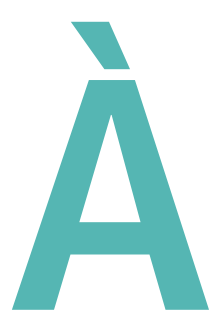

luz da missão da Universidade Lúrio [UniLúrio], "Educar e formar uma nova geração de profissionais competentes, comprometidos com a ciência, o desenvolvimento e o bem-estar das comunidades locais", o Magnífico Reitor da UniLúrio, Francisco Pedro dos Santos Noa, lançou o desafio aos coordenadores do projeto e curso de doutoramento em Patrimónios de Influência Portuguesa [PIP] do Instituto de Investigação Interdisciplinar e Centro de Estudos Sociais da Universidade de Coimbra [UC] para, em conjunto com a Faculdade de Arquitetura e Planeamento Físico da UniLúrio [FAPF], equacionar modelos de otimização do impacto catalisado pela instalação da Faculdade de Ciências Sociais e Humanas [FCSH] e do Centro de Estudos de Documentação da Ilha de Moçambique [CEDIM] da UniLúrio na llha de Moçambique.

A UniLúrio tem profunda e clara consciência da sua inserção e responsabilidade na Ilha de Moçambique, nesta designada era da globalização. Nela, a política e, sobretudo, a gestão ligada à cultura e, em particular, ao património, determinam e gerem âmbitos que têm a peculiaridade de cativar interesse mundial. A valorização crescente do património cultural e natural em Moçambique, no geral, e na llha, em particular, com a inscrição desta, em 1991, na Lista do Património Mundial da UNESCO, acentua a inserção do país nos caminhos da 
globalização. Fica cada vez mais claro que, tal como as políticas, a economia e o património Ihe estão ligados, é necessário que o ensino também esteja. Uma primeira adaptação do ensino superior a essa necessidade torna-se necessária para construir uma nova atitude nos âmbitos da investigação e inovação, fomentando parcerias qualificadas com a sociedade, as indústrias, as empresas, os centros tecnológicos e as instituições gestoras e culturais.

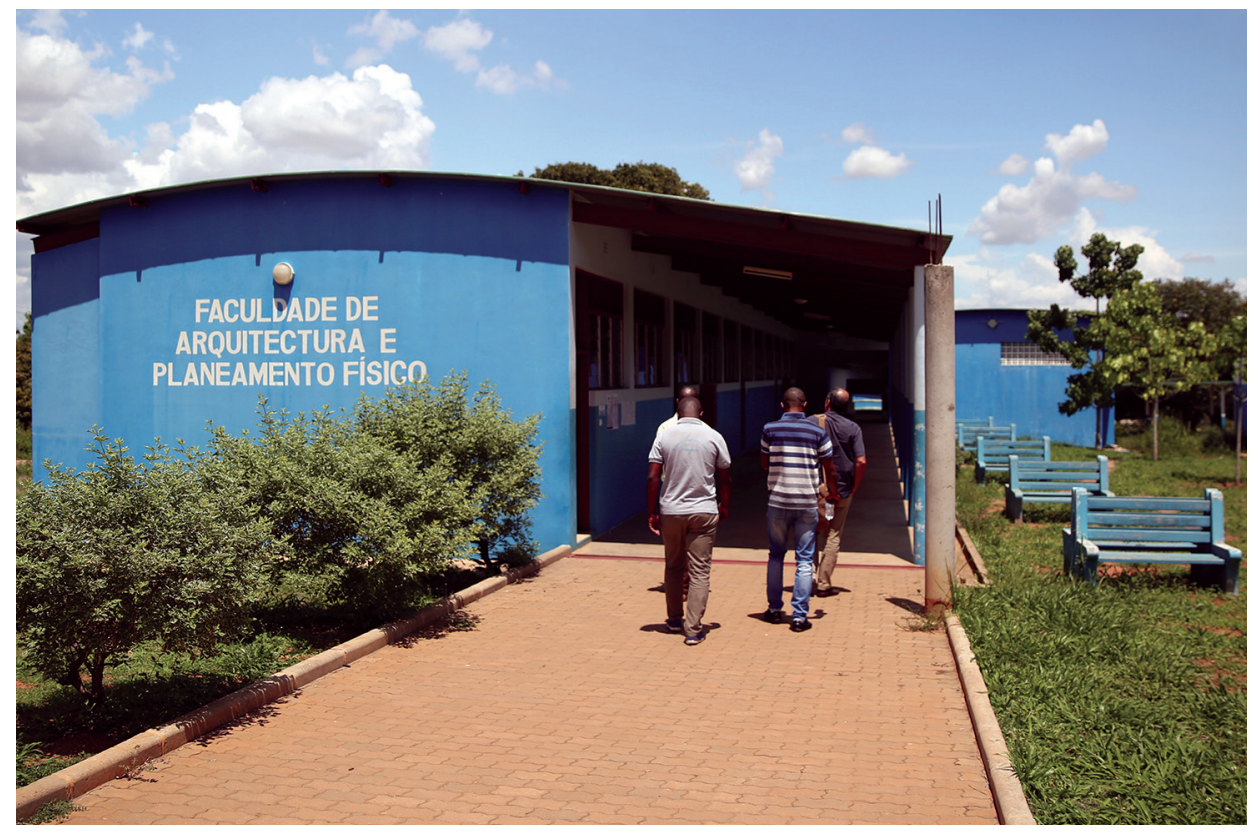

Este modelo pretende integrar igualmente a mobilidade dos alunos e dos docentes, favorecendo a empregabilidade e soluções no mercado alargado, tanto moçambicano como do resto do mundo, através da prática no processo de investigação. O aprofundamento da investigação aplicada em temas específicos relacionados com o património, implica que se definam conteúdos diversificados e transversais em vários domínios do saber científico. Conhecimentos e aprofundamentos que devem ser aplicados nas propostas de intervenções em formas metodologicamente certas e exequíveis.

As condições atuais da Ilha, as estruturas institucionais e legais, as condições socioeconómicas e mesmo a presente fase do 
desenvolvimento, justificam a produção frequente de eventos práticos com conteúdos relacionados com o património, conferindo, portanto, intervenções com competência e responsabilidade.

A adoção de métodos alternativos de aprendizagem e intervenção centrados no intercâmbio e mobilidade de estudantes, professores e investigadores, por via da participação em programas de pós-graduação e workshops, está a ser implementado entre as Universidades Lúrio e de Coimbra, de modo a tornar o processo de ensino capaz de apresentar soluções materializáveis na área de intervenção. Tais métodos vão ao encontro da real filosofia de mobilidade e internacionalização da Unilúrio, dos docentes e discentes. A UniLúrio adotou, desde o seu início, métodos de ensino e aprendizagem em que ao estudante é colocado o desafio de ser responsável na busca de soluções.

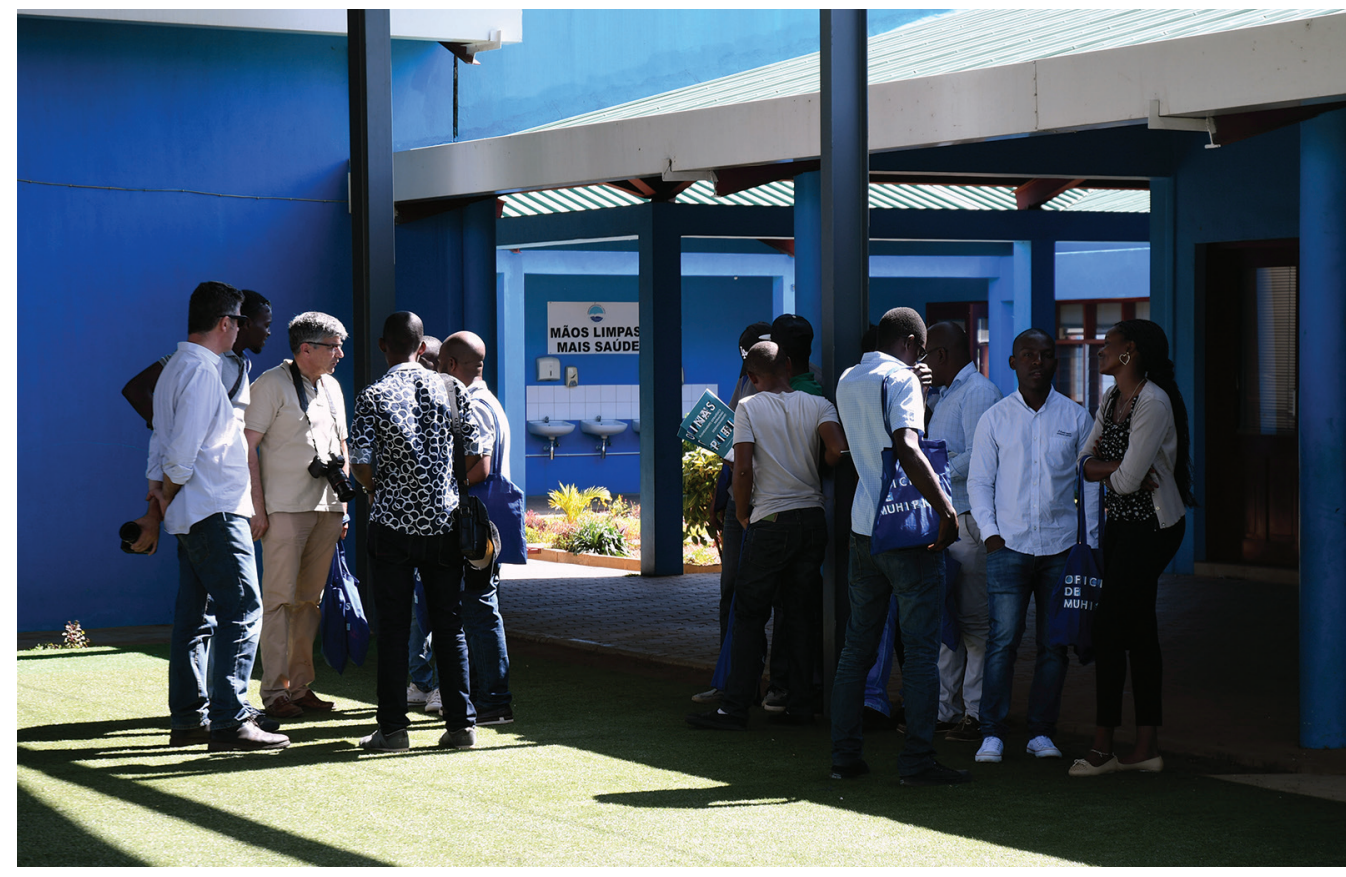

Um dos exemplos desta abordagem é o Mestrado em Património e Desenvolvimento que está a ser planeado para decorrer na llha e será oferecido com vista a poder realizar intercâmbios com instituições nacionais e internacionais dedicadas às questões do património cultural. 
A sua estrutura está a ser pensada de forma a servir também de veículo para a realização de doutoramentos por docentes da UniLúrio, oferecendo assim formação académica ao mais alto nível e, ainda, a criação de uma rede de trocas de experiências e conhecimentos que, decerto, contribuirá para o desenvolvimento do pensamento crítico e estratégico sobre as diversas vertentes das práticas patrimoniais, potenciando ações independentes, inovadoras e sustentáveis de celebração da identidade e da memória. Outro exemplo foi, precisamente, o workshop Oficinas Muhipiti: planeamento estratégico, património, desenvolvimento [Oficinas], que proporcionou um grande momento em que os estudantes foram confrontados com a dimensão interdisciplinar das matérias da Arquitetura e do Planeamento Físico e da transversalidade dos problemas no contexto do património.

Paralelamente ao alcance desse objetivo, existe a expectativa de se atingirem outros, tais como: a integração de atores locais no processo, através da participação e abordagens de aprendizagem viradas para a resolução de problemas específicos; a colocação de estudantes no centro do processo de aprendizagem; e a colocação da comunidade no processo das soluções, tendo sempre em conta a realidade local. Este processo didático enfatiza o propósito que as competências desenvolvidas pela universidade devem contemplar: não somente a aquisição de habilitações mas, acima de tudo, a união dos compromissos social e profissional. 
O Oficinas, alinhado com os programas de aprendizagem de Arquitetura e Urbanismo da UniLúrio, evidenciou que a diversidade no uso de estratégias de aprendizagem amplia a interdisciplinaridade, pela abordagem de outros campos disciplinares e pela integração de abordagens transversais de vários saberes. Consequentemente, os estudantes foram levados a confrontar-se com problemas de escala e valores diversos, à experimentação do incerto, ao estímulo da sua criatividade, à visualização diferenciada de problemas específicos. Aquele permanente contacto de contextos sócio-político-culturais, possibilitou aos estudantes experimentarem a vivência da realidade local que se inscreve nas experiências quotidianas da llha, facto que contribuiu e contribuirá consideravelmente para a preservação do seu património.

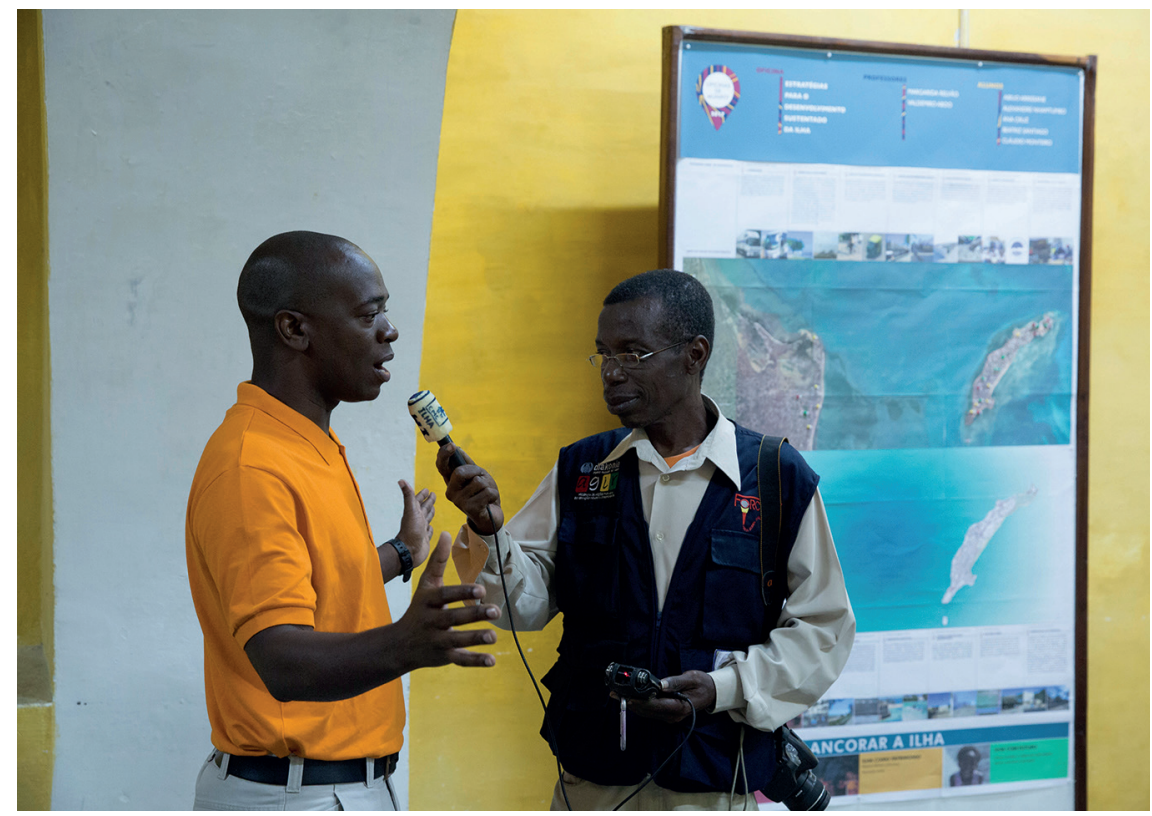

A intervenção no património impõe também um novo domínio de conhecimentos científicos que têm a ver com a sustentabilidade e a regeneração ambiental e que se adicionam, indispensavelmente, aos domínios que se prendem com os aspetos culturais, naturais, tipológicos, topológicos, topográficos, físico-químicos, antropológicos, sociológicos e dos domínios psicofisiológicos e estéticos. Pretendeu-se que o Oficinas fosse e continue a ser uma atividade inserida no conhecimento profundo 
do meio físico e cultural, pelo que se pode enraizar e estruturar uma cultura do espaço, autóctone e endógena, com base na investigação e no trabalho científico, através da FAPF, no geral, e do CEDIM, em particular.

Um dos resultados concretos e mais imediatos deste workshop será a criação, numa estrutura polinucleada, do Centro de Interpretação Muhipiti [CIM], uma plataforma integrada no CEDIM que atua na investigação, preservação e divulgação do património cultural, com base em métodos cientificamente validados, tendo em conta os tipos de património que a llha detém. A exposição preliminar dos resultados do Oficinas foi o momento zero do CIM, que em breve será substituída pela montagem do primeiro polo temático. Trata-se, pois, de um centro de interpretação dinâmico, que terá outros polos, quer na llha insular, quer no Lumbo, conforme o potencial patrimonial de cada local.

Foi assim que o Oficinas foi estruturado, de forma a responder a uma filosofia de ensino que centra no estudante a mais-valia no processo de aprendizagem, de forma a garantir o desenvolvimento sustentável, assim como melhorando e requalificando os assentamentos humanos, o desenho urbano, o restauro, a reabilitação, a manutenção de edifícios e o design de equipamentos. Os participantes foram sensibilizados para a história da realidade construída e a transformação da natureza pelo homem, para a ocupação social do espaço geográfico e mesmo dos elementos intangíveis dessas realidades, isto é, da própria personalidade do povo da llha, o seu ethos cultural.

O nosso anseio é que a experiência e resultados adquiridos ao longo do Oficinas auxilie a constituir uma ferramenta que integre os vários atores no seu processo, especificamente a Direção Nacional do Património Cultural [DNPC], o Gabinete de Conservação da Ilha de Moçambique [GACIM], e as autoridades locais, por forma a trabalhar com a comunidade e a servi-la melhor, tendo em conta o seu lema planeamento estratégico, património, desenvolvimento, segundo o qual decorreu o evento. 



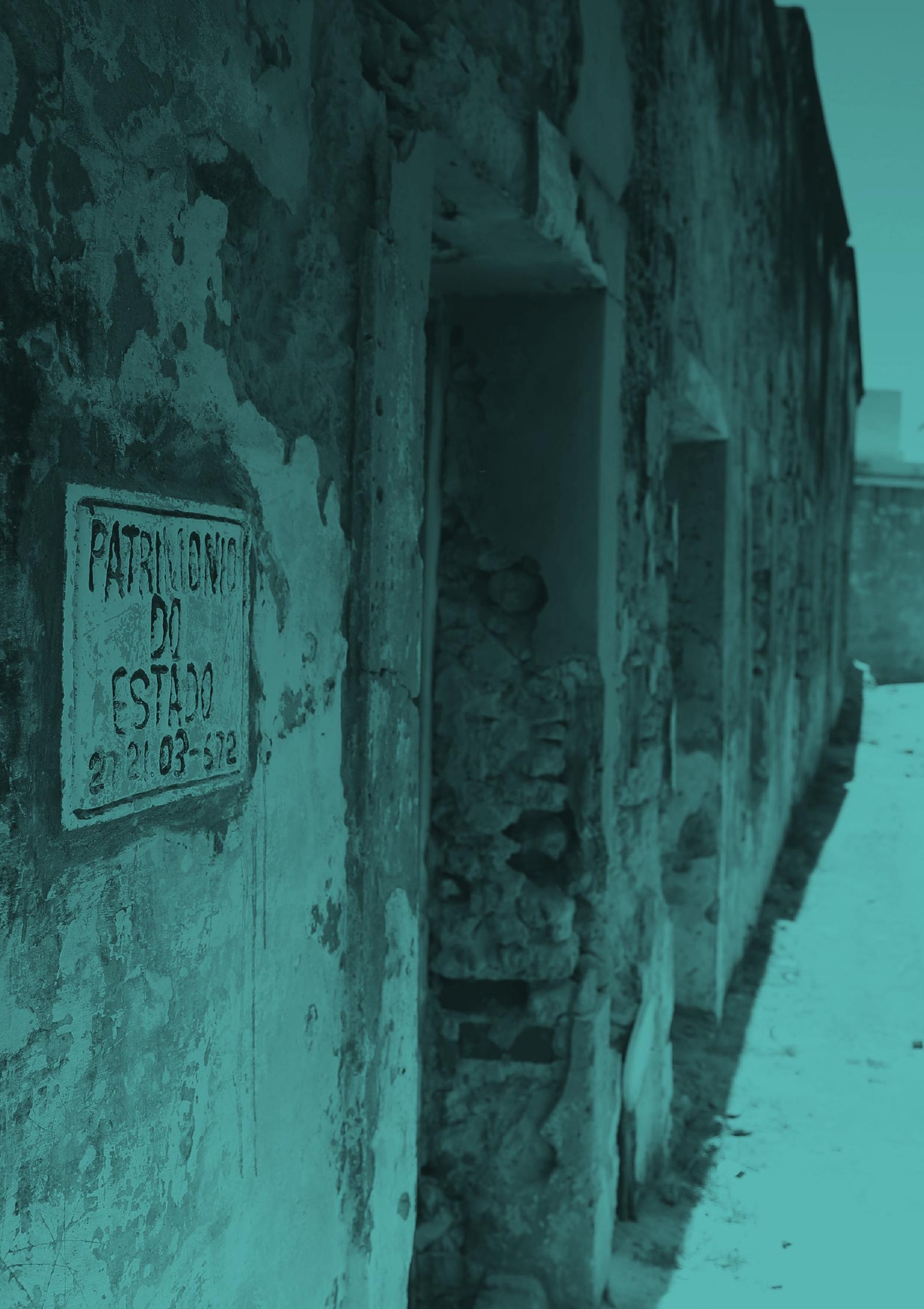




\section{SOBRE A PRESERVAÇÃO DO PATRIMÓNIO CULTURAL EDIFICADO \\ EM MOÇAMBIQUE}

Júlio Carrilho

Luís Lage

\section{INTRODUÇÃO}

Até à Independência Nacional, em 1975, alguns imóveis do património cultural e natural de Moçambique já tinham sido declarados como Monumentos Históricos. Em Maputo, através de uma portaria de 1964, tratou-se dos casos da antiga residência do Governador e da Fortaleza de Nossa Senhora da Conceição, respetivamente o atual Museu da Moeda ou Casa Amarela e a atual Fortaleza de Maputo.

No pós-independência, o primeiro passo no âmbito dos procedimentos legais para a salvaguarda do património cultural deu-se com a aprovação da Lei de Proteção do Património Cultural, em 1988, em que foram classificados os seguintes bens: todos os monumentos e elementos arqueológicos; todos os prédios e edificaç̃es erguidas em data anterior a 1920; as principais bases operacionais da Frente de Libertação de Moçambique [FRELIMO].

A Direção Nacional do Património do Ministério do Turismo e Cultura, com a colaboração da Faculdade de Arquitetura e Planeamento Físico da Universidade Eduardo Mondlane [FAPF-UEM], foram efetuando, ao longo do tempo, a recolha sistemática do património edificado das cidades e pequenos centros populacionais do país. Esta recolha foi realizada através de atividades de investigação e extensão com o objetivo de inventariar e adequar o edificado às eventuais exigências de uso pelos diversos utilizadores emergentes (municipalidades, autoridades delegadas à tutela do património, arquivos históricos, entre outros). 


\section{A VONTADE RECORRENTE DE APAGAMENTO DO PASSADO E O AFÃ DE NOVAS REFERÊNCIAS}

Transformações profundas de contexto sociopolítico, traduzidas por profundas mudanças de regime, são frequentemente acompanhadas de processos de reafirmação das novas realidades e valores que se considera importante exaltar. Estes processos de reafirmação transportam consigo algo subjacente de apagar do passado, que é sujeito de recusa. A independência de Moçambique do domínio português revelou fenómenos deste tipo, designadamente: a substituição de topónimos por todo o país; o desmonte ou derrube de estátuas e marcos de exaltação de valores, personagens ou acontecimentos históricos do colonialismo; o abandono de lugares simbólicos da afirmação colonial. Nalguns casos tais atos foram realizados de modo a, publicamente, se manifestar uma alter-individualidade que se sobrepõe a uma história de humilhação e de domínio.

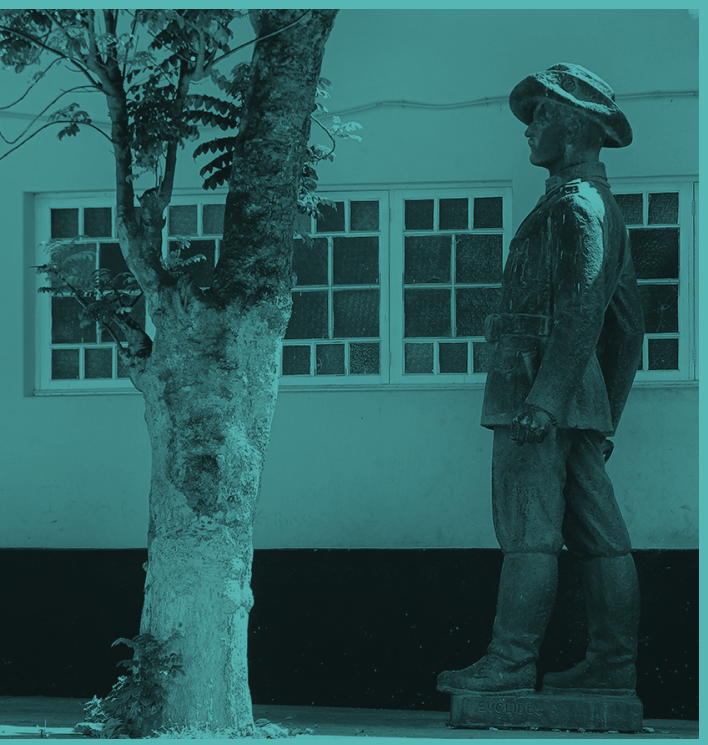

Mudar um nome ou derrubar uma estátua é mais do que uma mera substituição de personagens e símbolos urbanos, é, sobretudo, uma afirmação de novas presenças. Presenças de entidades concretas ou simbólicas que, secundarizadas durante muito tempo, renascem e se apresentam à luz do dia como valor local a ser realçado na sociedade, no tempo e no espaço. Estes processos de transformação foram rápidos, quando as lembranças subjacentes do passado eram ainda muito evidentes. É o caso das estátuas ou conjuntos esculturais em lugares centrais das cidades, sendo os exemplos mais marcantes o derrube do conjunto escultórico exaltando Mouzinho de Albuquerque, na cidade de Maputo, e do conjunto escultórico dedicado a Neutel de Abreu, na cidade de Nampula. 
Mas nem sempre o apagamento da história se fez através do derrube dos símbolos urbanos. Outra forma de afirmação da nova realidade foi a ocupação de espaços com elementos reveladores do seu uso como lugar e/ou instrumento de dominação. É o caso da transformação de espaços que foram lugares de práticas de subjugação e tortura realizadas no período colonial, em espaços de memória e exposição dessas práticas, como o caso da Vila Algarve, em Maputo, logo após à proclamação da independência.

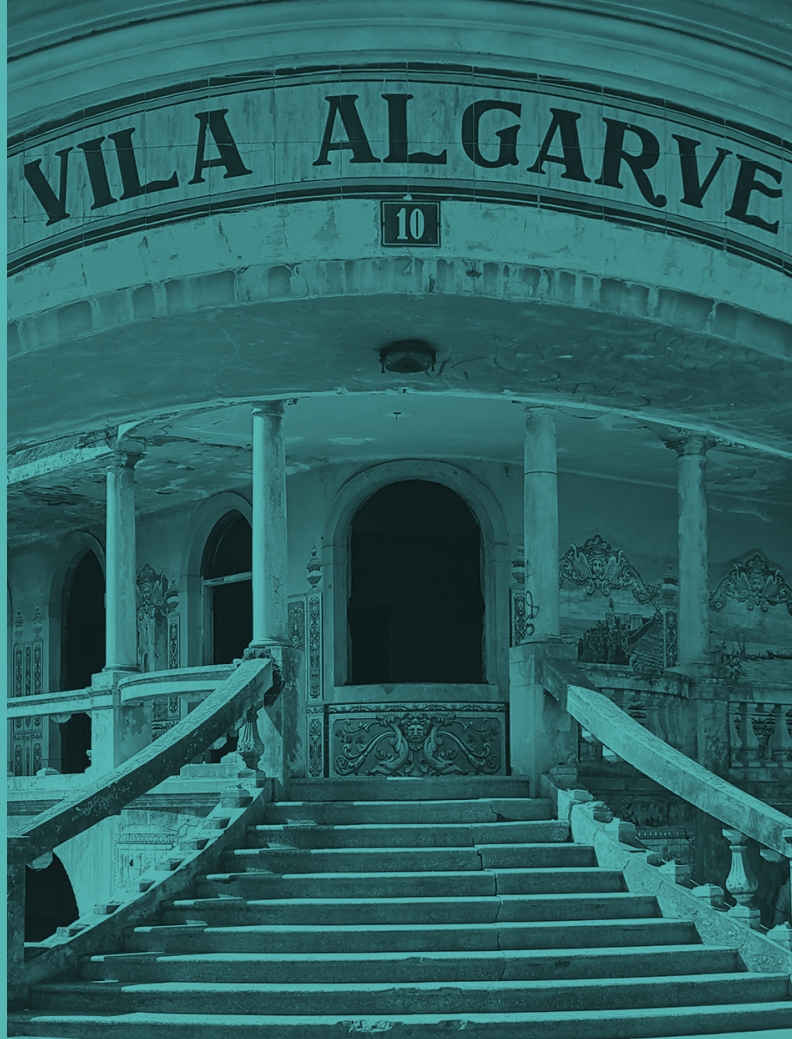

Convém referir que, no domínio do simbólico, a apropriação de espaços em que a representação não está diretamente ligada a processos de expressão de poder, não se verificaram processos de recusa ou de indiferença. Temos como exemplo os espaços de representação de natureza etnológica (Museu de Nampula) ou de carácter ambiental, ligada à fauna ou flora (Museu de História Natural de Maputo), que foram naturalmente agregados ao novo sistema de valores, mesmo quando a arquitetura exprime muito claramente valores de afirmação tipicamente colonial (neo-manuelino, Estado Novo ou, ainda, de extração popular-regionalista da metrópole), ou mesmo quando a representação etnológica do africano aparece, de forma indireta, associada à fauna, flora e costumes "bizarros" (Serra, 2015).

Um exercício esquemático da abordagem geral pós-independência pode revelar 5 períodos de ênfases relativamente distintos: (1) o período imediatamente após a declaração da independência, de 25 de junho de 1975 até 1977, no qual se verifica o abatimento dos símbolos edificados do poder colonial e se enfatiza a importância da preservação do edificado ligado à luta de libertação nacional e ao resgate de valores culturais populares intangíveis (através dos grandes festivais nacionais 
de música, canto e dança tradicionais/populares, movimento que se estendeu por todos os períodos); (2) um período curto em que se inicia o estudo e a apropriação do património edificado preexistente, procedendo-se, com naturalidade, à sua incorporação no corpus do património edificado como coisa nacional, como são disso exemplo os casos da Ilha de Moçambique e da Baixa de Maputo; (3) o período de 16 anos da guerra pós-independência, em que a governação se concentra na realidade militar, passando as preocupações de gestão do património edificado para um plano secundário; (4) o período pós Acordo Geral de Paz, assinado em Roma a 4 de outubro de 1992, em que se retomam os processos normais de gestão do país, incluindo os aspetos culturais em que se insere a problemática do património edificado. Neste período avulta de novo a necessidade de afirmação de elementos simbólicos nacionais através da presença de personagens, sítios e acontecimentos relevantes da gesta da luta pela independência - é o caso das Praças dos Heróis, das bases político-militares da luta de libertação nacional, como Matcheje (onde, em 1978, foi realizado o II Congresso da FRELIMO) - e as estátuas de Samora Machel e de outros combatentes (replicadas em praças de cidades capitais provinciais); (5) o último período, incluindo o presente, é caracterizado por uma busca mais aprofundada de definição do património cultural edificado, centrado nos processos metodológicos específicos, de negociação e consciencialização, que inclui as etapas de levantamento, inventariação, registo, legitimação e divulgação em que se enquadram várias publicações. A urgência da afirmação de novos símbolos edificados endógenos para a nova realidade pós-independência, condicionada pela falta de tempo e tradição nos processos da sua definição (conceção, legitimação, projeto e construção), levou a que se instalassem atitudes de repetição, de inspiração e cópia direta do que se produzia na capital do país. Isto evidencia que, no domínio da criação de novas referências simbólicas nacionais de património edificado e espacial urbanos, se está ainda numa fase embrionária de aprendizagem, caracterizada por comportamentos locais de mimetização face aos escalões mais altos de decisão, capital ou governos central e provincial, por vezes sem intervenção local. 


\section{UMA CONSTRUÇÃO COLETIVA REITERADA PELOS ANTIGOS EX-PROPRIETÁRIOS COMO SUA}

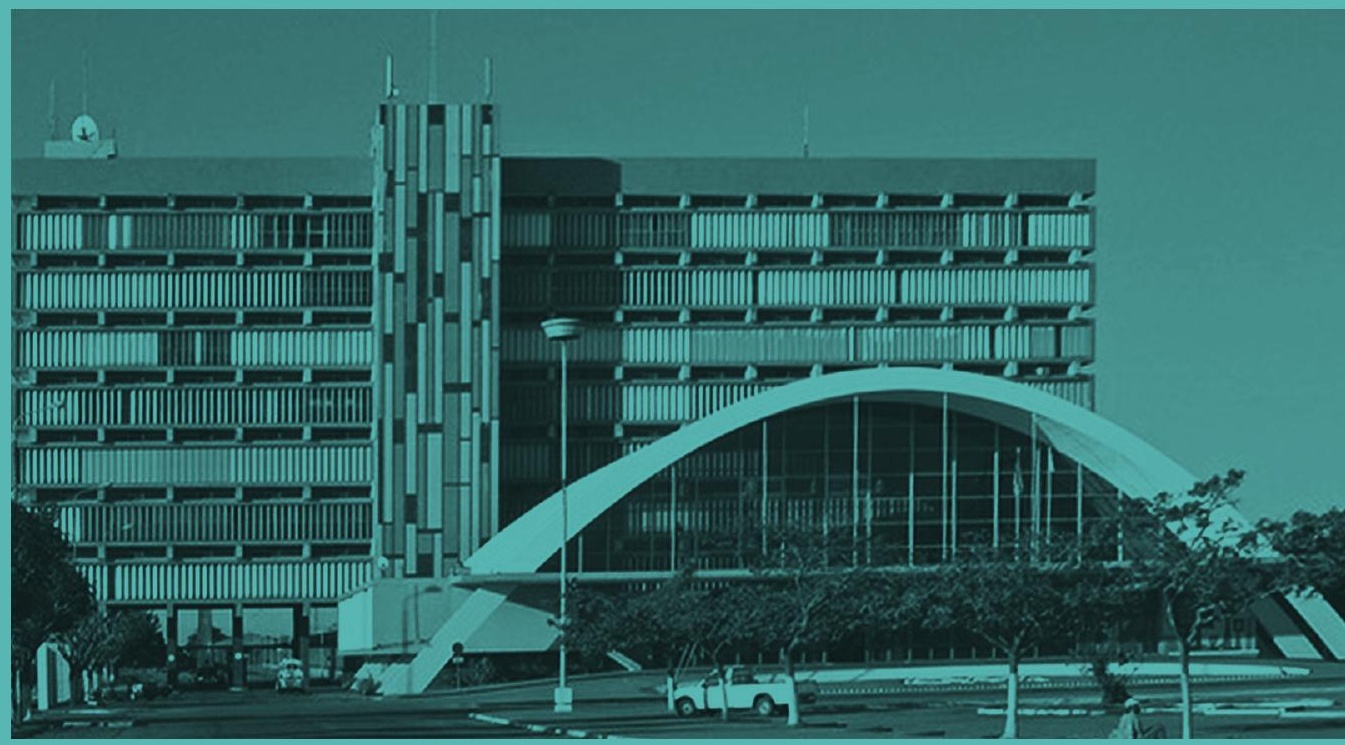

Relativamente aos estudos ligados à herança arquitetónica, avulta a ideia errónea de que o que foi construído no período colonial é legado do colonialismo, é património do colonizador e, em última análise, produto e pertença de outrem. Estamos num campo em que os próprios teóricos de arquitetura contemporâneos dos países outrora dominadores reclamam para a sua cultura os louros da originalidade das abordagens espaciais, de qualidade inquestionável, de objetos construídos em território estranho à sua metrópole. Quer dizer: os construtores são apenas vistos como meros instrumentos da realização de uma ideia; o clima, a realidade ambiental, os desafios do território são apenas factos técnicos; os contrastes de luz, o apelo da cor, o carácter icónico dos objetos, os simbolismos iconográficos do imaginário popular, são apenas fruto do exercício de descoberta e da genialidade dos projetistas do tempo colonial, sem nada que os ligue à natureza, às vontades e às culturas em que os objetos se inserem na contemporaneidade. A visão do outro é fruto de uma espécie de cegueira quanto à sua existência. Assim, torna-se impossível a reclamação da propriedade desses bens por quem os construiu, a compreensível apropriação pelos que possibilitaram 
a sua existência, pelos que os possuem como propriedade sua e nacional. É provável que também daqui resulte a dúvida quanto à pertinência histórica da sua conservação e valorização como património nacional dos países em construção e afirmação. É por isso que o exercício e a apropriação desse património edificado, que a nível académico tanto se defende, se transforma num exercício muito condicionado pela política, pelas perceções das elites, pelas dinâmicas das forças em presença, por vezes feitos à margem dos critérios de qualidade, inovação e de contribuição para o futuro que esses objetos podem constituir para a sociedade e gerações vindouras.

\section{A PERSUASÃO DA MODERNIDADE}

O levantamento de elementos da arquitetura popular permitiu constatar o impacto da imagem do moderno, não apenas nas periferias das cidades, mas também em pleno contexto rural. No contexto rural, a imagem do que é moderno, também associada à ideia do novo, vai ser apropriada pelos moradores a partir da cidade moderna. Vai-se buscar à forma a ideia de modernidade a adotar na arquitetura, muitas vezes sem se ter acesso aos materiais e a outros elementos que a conformam no contexto urbano. A dimensão do construído e a utilização da linha direita fascinam como novidade num ambiente de formas orgânicas e, frequentemente, de natureza curvilínea. Nas periferias das cidades, os elementos construtivos (como as lajes e as palas de proteção em betão e os elementos de ventilação e as varandas) são usados como elementos decorativos ou da busca de segurança e durabilidade. Se no âmbito político se reafirma a necessidade, de certo modo passadista, de se buscar a inspiração na arquitetura rural como elemento de identidade e afirmação da nossa tradição, os construtores dos objetos da arquitetura vão buscar os exemplos de como fazer, precisamente na forma, nos materiais e técnicas exógenas. É no equilíbrio entre o mais adequado e apropriado, o mais durável e económico, a tradição e a modernidade, que se trava a batalha da transformação da arquitetura popular naquilo que se percebe como sendo a afirmação da superioridade da arquitetura moderna. 


\section{O DESAFIO DO USO}

O uso dos espaços está intimamente ligado à carga cultural de quem os concebe e daqueles que deles se apropriam. A desconexão e tensão entre estes sujeitos pode conduzir a incompatibilidades de uso com efeitos negativos na manutenção e na durabilidade do edificado. É verdade que há uma dimensão económica no binómio projetouso, mas parece não haver dúvida de que os modos de vida que os usuários transportam consigo têm uma grande importância na eficácia da apropriação das propostas de espacialidade disponíveis.

O objetivo político de contrariar a segregação urbana do período colonial foi, em parte e momentaneamente, alcançado com a ocupação da cidade pela população indiferenciada, independentemente da natureza socioeconómica dos novos moradores, quer eles fossem provenientes das áreas pericentrais marginalizadas, quer fossem oriundos do mundo rural (sobretudo através da lei da nacionalização dos prédios de rendimento, em 1976). Este fenómeno de disfuncionalidade entre a cidade desocupada e os seus novos moradores foi sendo corrigido pela reversão da nacionalização dos imóveis de rendimento, em 1991 (Decreto $n^{\circ} 2 / 91$ ), e da atividade

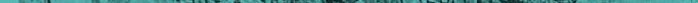


do mercado, permanecendo um desajuste em muitos casos. Um dos resultados desta disfuncionalidade é o envelhecimento precoce do edificado, que atinge também edifícios de grande valor patrimonial arquitetónico, bem como o impacto negativo da valorização dos espaços em que eles estão inseridos no conjunto urbano, e que conduz à sua destruição e substituição por edificações com resultados económicos imediatos mais apetecíveis. Isto é potenciado por uma perceção em que muitas vezes está ausente o imperativo de proteção desse património, frequentemente associado a uma realidade de sofrimento que ninguém quer ver repetido historicamente.

Num contexto de grande volatilidade e de rápidas transformações, valia a pena ponderar-se se a única atitude de preservação do património deveria limitar-se a garantir a sua sobrevivência como elemento da paisagem urbana, ou se se poderia recorrer a outros métodos que assegurassem a permanência da sua memória, ou seja, resgatá-lo da sua morte excecional quando for impossível manter fisicamente o bem edificado. Um exemplo interessante desta abordagem pode ser dado pelo seguinte facto: há alguns anos um edifício que era geralmente considerado como tendo valor patrimonial foi destruído pelo concessionário do terreno, muito bem localizado, em que ele estava inserido. As autoridades da Cultura com tutela, bem como a imprensa, deram destaque ao caso, mas já não era possível repor o edifício. Qual foi a atitude tomada? Foi a de persuadir o novo concessionário a considerar este facto, criticado geralmente pelos círculos conservacionistas, e, no projeto para o edifício de rendimento a erigir no local, considerar um espaço de memória com acesso ao público, em que se reproduzisse tecnicamente o edifício demolido, contratando para o efeito uma equipa especializada que procedesse ao seu levantamento e execução rigorosos de uma maqueta. No caso, similar, do novo edifício-sede da administração aduaneira, localizado no limite do conjunto protegido da Baixa de Maputo, esta prática já tinha sido ensaiada com resultados positivos, tendo o promotor financiado o levantamento rigoroso do conjunto urbano, que teve de se demolir e que foi realizado sob a direção da FAPF-UEM. 


\section{O DESAFIO DA APROPRIAÇÃO}

Em relação ao património cultural edificado de Moçambique, a sensibilidade institucional que se tem vindo a construir, em particular junto do Ministério da Cultura e, por extensão, junto dos responsáveis por este assunto ao nível das instituições governamentais, permitiu, entre outras ações, que se tivesse conseguido:

- a elevação da Ilha de Moçambique à qualidade de conjunto edificado a proteger;

- $\quad$ a proteção do conjunto edificado da Baixa de Maputo;

- a criação do Conselho Nacional do Património Cultural para, numa situação em que se verificam muitas lacunas legais e regulamentares, aconselhar os órgãos do Estado sobre matérias especializadas no âmbito da preservação do património cultural tangível e intangível;

- a realização de várias conferências nacionais dedicadas a assuntos culturais, em que se discutiu a preservação do património cultural, como o património edificado, a ser um dos temas tratados;

- a criação no Ministério da Cultura de um departamento especificamente dedicado à problemática da preservação do edificado no quadro do património cultural;

- a permanente articulação com a FAPF-UEM no que respeita à análise, qualificação, salvaguarda, proteção e regulamentação do património edificado, tendo a faculdade colaborado na redação da Lei de Proteção do Património Edificado e do Regulamento dos Bens Classificados na llha de Moçambique, recentemente (2016) aprovados pelo Conselho de Ministros;

- a realização de seminários multidisciplinares com especialistas de diversas áreas do conhecimento, bem como de pessoas notáveis e cidadãos interessados, para se promover a inventariação, seleção e eleição de edifícios com valor patrimonial a destacar, através de um sistema de discussão e votação; seminários deste tipo foram realizados em Maputo, Beira, Ilha do Ibo e llha de Moçambique.

Este tipo de intervenção, com o patrocínio ou anuência das autoridades pertinentes, permite elevar a consciência do valor do património edificado, assinalar a importância da sua salvaguarda, proteção e valorização e, principalmente, a apropriação e gradual empatia com o edificado a proteger. 


\section{O DESAFIO DO SENTIDO DE PERTENÇA}

O sentido de pertença é um dos fios que tece o pano de fundo de perceções e problemas que enquadram, encorajam ou limitam a discussão da problemática do património cultural em Moçambique. Por exemplo: 1) para alguns, salvaguardar o património tangível referente à presença colonial pode ser considerado desnecessário por não se estar confortável com essa realidade desqualificante que se sente não ser nossa. A verdade é que os elementos tangíveis criados nesse período representam processos complexos, por vezes únicos, de interação ao longo da história, sendo claramente justificada a sua preservação (DNPC, 1993: 2). Quer dizer, o dever de preservação do património refere-se não apenas àquilo que se considera pertencer ao país, mas também a bens de valor que, percebendo-se como sendo alheios, se imbricaram na realidade nacional, ficando à responsabilidade dos moçambicanos; 2) para outros, a recuperação de património tangível autóctone com maior grau de efemeridade, nomeadamente construções e objetos de materiais naturais, é também desnecessária pela dificuldade que isso representa e porque se trataria de agir sobre uma realidade precária e em constante mudança que, mesmo sendo importante para compreender o que virá no futuro, é demasiado oneroso e complexo. A este propósito convém, no entanto, referir a Carta de Veneza (1964) que, logo no seu primeiro artigo, postula que o conceito de monumento histórico se aplica não apenas a grandes obras mas também a obras modestas do passado que adquiriram significado cultural.

É recorrente a discussão da problemática do sentido de pertença, no âmbito do património cultural, desembocar na questão de "quem é o possuidor do passado?" (apud Egan, 2010). Nalguns debates que se têm feito no país, alguns participantes de círculos diferenciados da sociedade sugerem que uma maior consciencialização neste domínio poderia facilitar a definição e aplicação de políticas sustentadas de salvaguarda e conservação do património edificado. É provável que a presença, ainda fresca, das lembranças dos processos dolorosos de dominação e discriminação coloniais explique muitas das reticências, alguma indiferença, um certo oportunismo e a falta de empatia que por vezes se verifica entre alguns dos moçambicanos perante o património originado nesse período conturbado da história do país. 


\section{QUESTÕES METODOLÓGICAS}

Partindo de uma abordagem transversal, o método utilizado definiu-se pelas condições disponibilizadas e pelos recursos existentes no país, tendo como objetivo a chegada de consensos para a apresentação de propostas de classificação de determinados edifícios de Maputo e da Beira aos seus respetivos Conselhos Municipais. Adotaram-se, assim, as seguintes etapas:

- definição das equipas de trabalho e chefias, efetuado pela FAPF-UEM;

- inventariação preliminar dos edifícios que constituiriam o universo da amostra sobre a qual se trabalharia, e reunião preparatória de toda a informação disponível de interesse;

- seleção expedita dos edifícios considerados;

- recolha preliminar de informação bibliográfica e iconográfica visando a caracterização geral dos edifícios selecionados na amostragem preliminar;

- visitas de campo para testar as hipóteses colocadas, com levantamentos arquitetónicos e iconográficos complementares feitos por equipas técnicas qualificadas;

- definição hipotética de uma lista restrita de edifícios a salvaguardar;

- preparação do dossier a ser submetido aos consultores durante os seminários multidisciplinares de consulta pública;

- preparação dos seminários multidisciplinares de consulta pública;

- realização dos seminários de consulta para apresentação, análise e discussão dos critérios e das opções preliminares estabelecidas com vista à definição final do universo da amostra;

- definição por consenso ou votação da lista estrita de edifícios selecionados a proteger, na base de um número reduzido de edificações ou objetos urbanos definidos após consultas multidisciplinares do processo preliminar. 


\section{- Regulamento sobre a Gestão de Bens Culturais Imóveis}

A FAPF-UEM colaborou com o Ministério da Cultura, prestando apoio na elaboração do Regulamento sobre a Gestão de Bens Culturais Imóveis aprovado pelo decreto 55/2016 de 28 de novembro de 2016. O regulamento visa a classificação, proteção adequada, conservação e gestão sustentáveis dos bens culturais imóveis, sendo estes estruturados consoante o seu valor relativo nas seguintes classes:

- A+, património e bens culturais do Estado Moçambicano com categoria de Património Mundial com valor universal excecional;

- A, património e bens culturais de valor elevado nacional, incluindo aqueles que têm o potencial de contribuir significativamente para objetivos de pesquisa e investigação nacional;

- B, património e bens culturais de valor médio local, incluindo aqueles que têm o potencial de contribuir significativamente para objetivos de pesquisa e investigação local;

- C, património e bens culturais de valor limitado local, incluindo aqueles que têm o potencial de contribuir para os objetivos de pesquisa e investigação no âmbito local;

- D, património e bens culturais de limitado valor individual relativo, que, como parte de um contexto ou conjunto mais vasto, contribui positivamente para o carácter do ambiente urbano ou rural local em que se insere. Incluem-se neste contexto bens que apresentem um uso característico de desenho, técnicas e materiais de um período ou tipo particulares de edificação.

O Regulamento define também os níveis de intervenção para cada uma das classes, assim como a criação de Comissões de Gestão de Bens Culturais Imóveis, com o objetivo de garantir a proteção do património cultural pelas comunidades locais, como legítimos guardiões e beneficiários. 


\section{- Plano de Urbanização da Vila do Ibo}

Este plano foi elaborado em 2008, através de um contrato entre a Direção Provincial para a Coordenação da Ação Ambiental de Cabo Delgado e a FAPF-UEM. A importância deste plano justificava-se pelo valor patrimonial, histórico e cultural da llha do Ibo e das Quirimbas. Preconizaram-se ações de restauro de conservação para todos os edifícios monumentos através da reposição do seu estado original, com eventuais melhorias ou modernizações das suas funcionalidades e de ações de reabilitação, com ou sem refuncionalização, mantendo-se a imagem e o traçado originais no exterior, optando-se, quando necessário, por processos de modernização em tecnologias e materiais, de modo a garantir maior longevidade e conforto.

O regulamento do plano define também as normas para a recomposição do tecido urbano, a manutenção da escala humana típica do conjunto edificado da vila, o respeito pela criação de espaços de transição entre a rua e o espaço interior através do sistema de varandas com colunatas, a manutenção da simetria das fachadas, a preferência pela cobertura em telha e também o uso, nas fachadas, de paletas cromáticas coerentes com a cor do conjunto.

O regulamento procura também restringir, de uma maneira geral, o uso de certos materiais locais que se traduzam em destruição, a prazo, de recursos naturais com impacto negativo no equilíbrio ecológico insular.

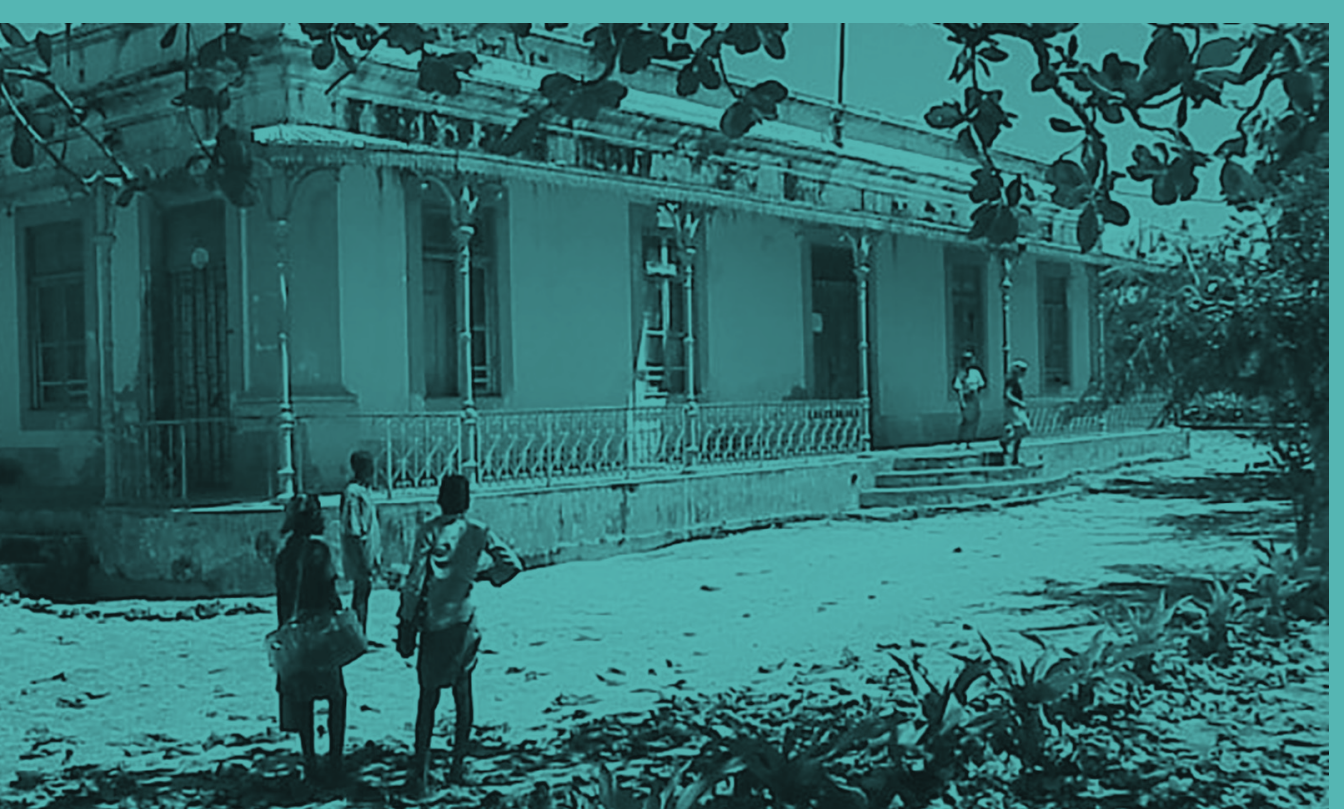




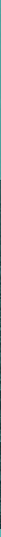

\section{- Plano Parcial de Urbanização da Baixa de Maputo}

Este plano foi executado em 2015 pelo Conselho Municipal de Maputo e o consórcio entre a Cardno Emerging Markets, a Design Convergence Urbanism e a FAPF-UEM.

Tendo em conta esse fator, o crescimento rápido da cidade e uma vez que o tecido histórico de ruas residenciais, edifícios e espaços públicos fornecem à cidade o seu carácter distinto, procurou-se estabelecer, através da regulamentação do plano, uma agenda imediata para a sua preservação. O plano classificou 314 edifícios distribuídos pelas classes estabelecidas pelo Regulamento sobre a Gestão de Bens Culturais Imóveis. O regulamento define duas zonas delimitadas de proteção: a do núcleo inicial da cidade e a industrial. Novas intervenções deverão garantir o respeito pelas delimitações e padrões dos talhões existentes, pelo carácter e pela escala das fachadas dos quarteirões e do edificado na envolvente dos bens históricos classificados individualmente, e pelas cérceas definidas nas respetivas fichas de ordenamento do plano. Preconiza também as linhas de vista-mar, através das vias da malha urbana no núcleo inicial da cidade, impedindo a sua obstrução. Foram também designadas interconexões especiais de praças da zona da Baixa, através das vias de circulação, relacionando as suas três principais praças de épocas diferentes. Qualquer nova intervenção deverá respeitar e realçar a composição planeada da malha, incluindo o traçado arquitetónico predominante, e garantir que sejam de materiais apropriados ao carácter do espaço. O Regulamento confere ainda destaque aos espaços públicos com interesse patrimonial. 


\section{- Regulamento sobre Classificação e Gestão do Património Edificado e Paisagístico da Ilha de Moçambique}

Por contratação do Ministério da Cultura através do Conselho Nacional do Património Cultural, a FAPF elaborou, em 2014, o Regulamento sobre Classificação e Gestão do Património Edificado e Paisagístico da llha de Moçambique, aprovado pelo Decreto 54/2016 de novembro de 2016. Foram classificados 510 edifícios de pedra e cal, estabelecendo-se que qualquer intervenção sobre o património edificado da cidade da Ilha de Moçambique deverá obedecer aos critérios gerais de autenticidade, integridade, legibilidade, reversibilidade, identidade cultural e ambiental do edificado preexistente. Estes critérios deverão ser considerados nos processos de intervenção, no conjunto ou isoladamente, relativamente aos processos de requalificação do edificado no contexto urbano, aos diferentes elementos construtivos, salvaguardando o traçado original aparente dos edifícios e das fachadas, e respeitando a escala e a continuidade de desenho de imagem.

Neste regulamento deu-se também importância, tal como na llha do Ibo, ao uso dos materiais para a conservação e restauro, devendo ser preferencialmente originais ou precedentemente aplicados para as construções de pedra e cal, abrindo a possibilidade, em novas construções, de introdução de materiais diferentes sempre que se respeite o espírito do lugar.

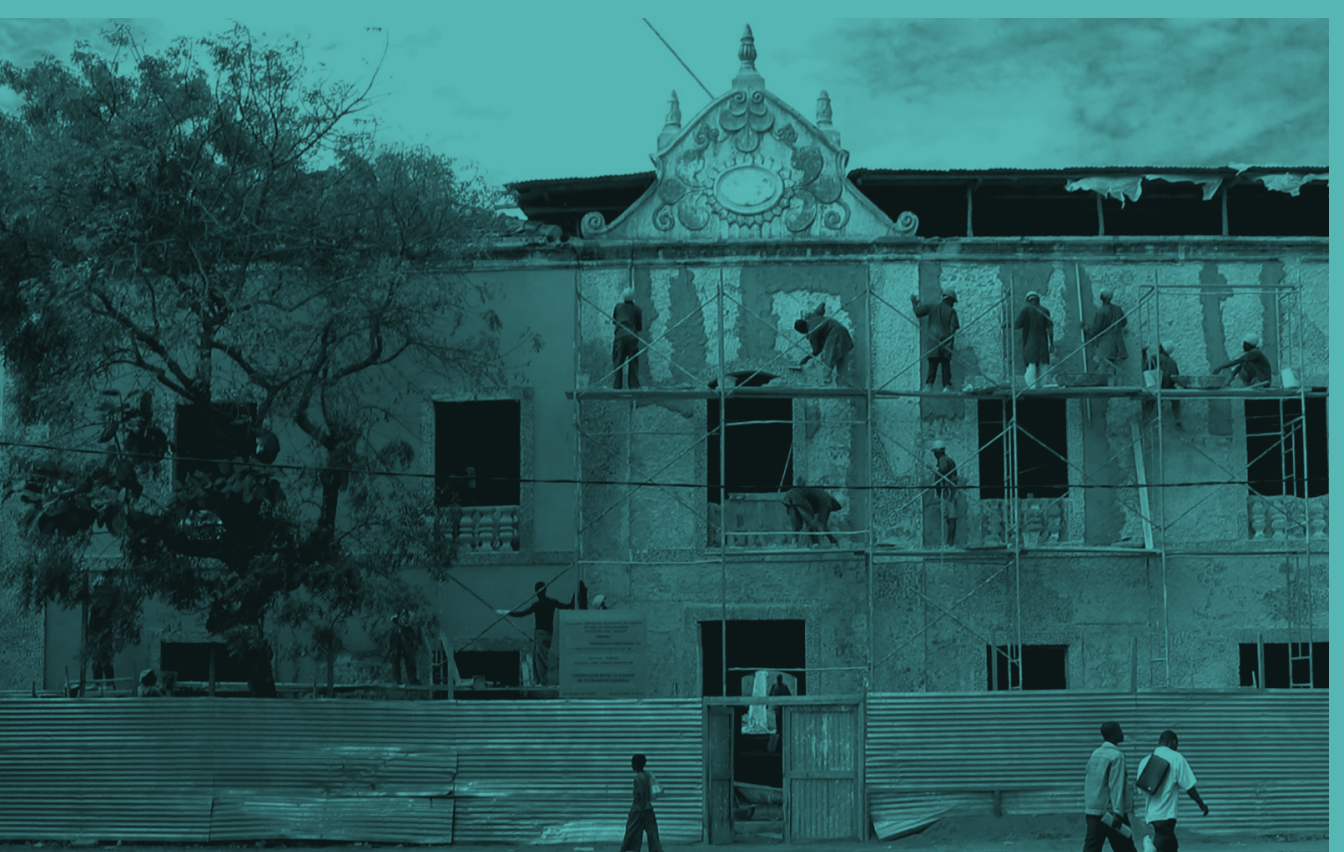




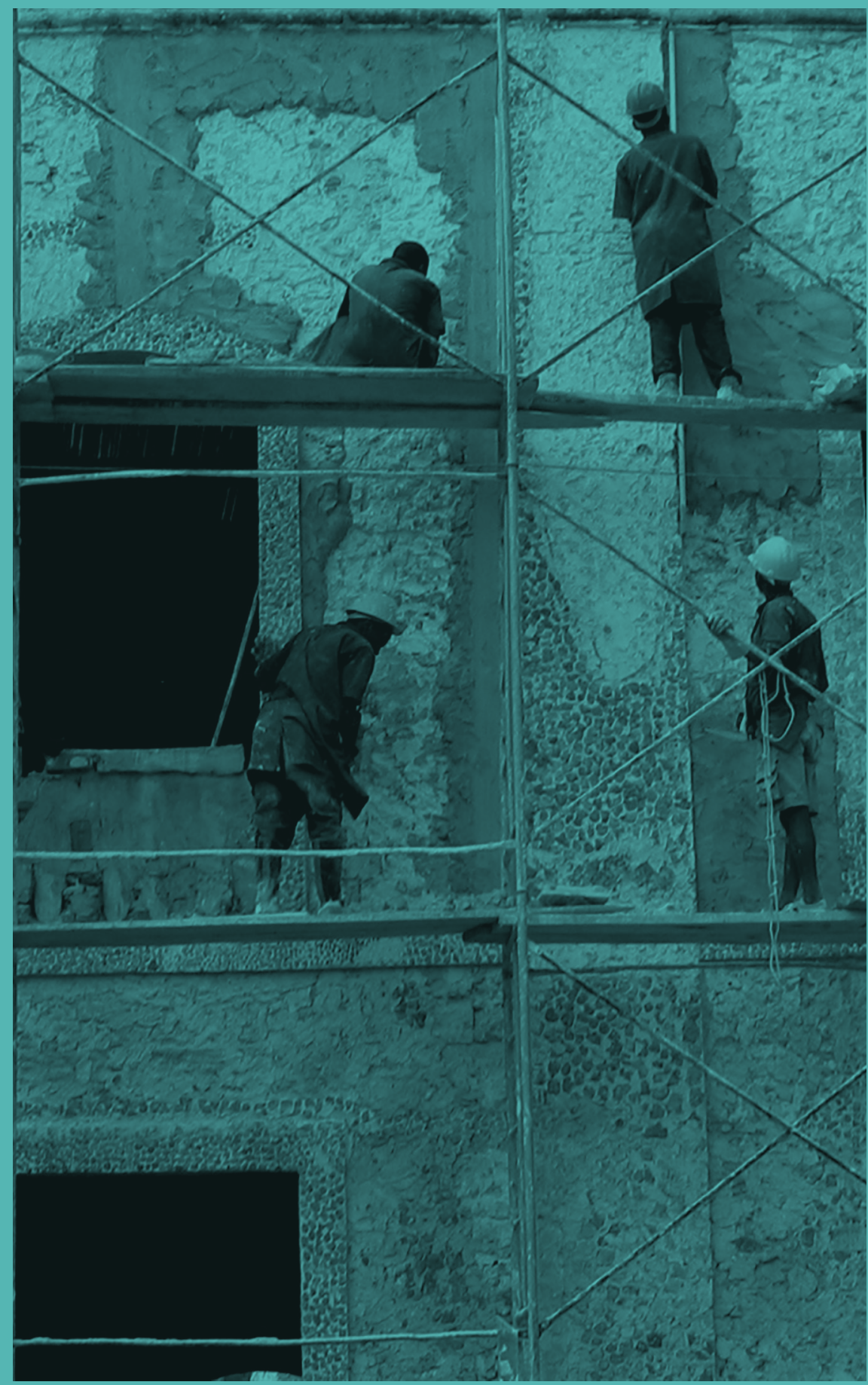




\section{CONCLUSÕES PRELIMINARES}

Os principais desafios que Moçambique enfrenta estão ligados à formação e treino nas práticas de preservação e conservação, à elevação das capacidades institucionais para o estudo, regulamentação e monitorização, bem como ao estabelecimento de mecanismos de envolvimento dos diferentes tipos de agentes económicos e sociais, incluindo os proprietários individuais de edifícios com valor patrimonial. Mas também à carência de fundos dedicados ao estudo, salvaguarda, preservação e manutenção do património; à consciencialização e educação permanente do público para a importância do património edificado; à descentralização regulada de atividades, com a consequente elevação do significado do sentido de pertença, de partilha coletiva e de sustentabilidade em relação às atividades ligadas à preservação do património cultural, incluindo o edificado.

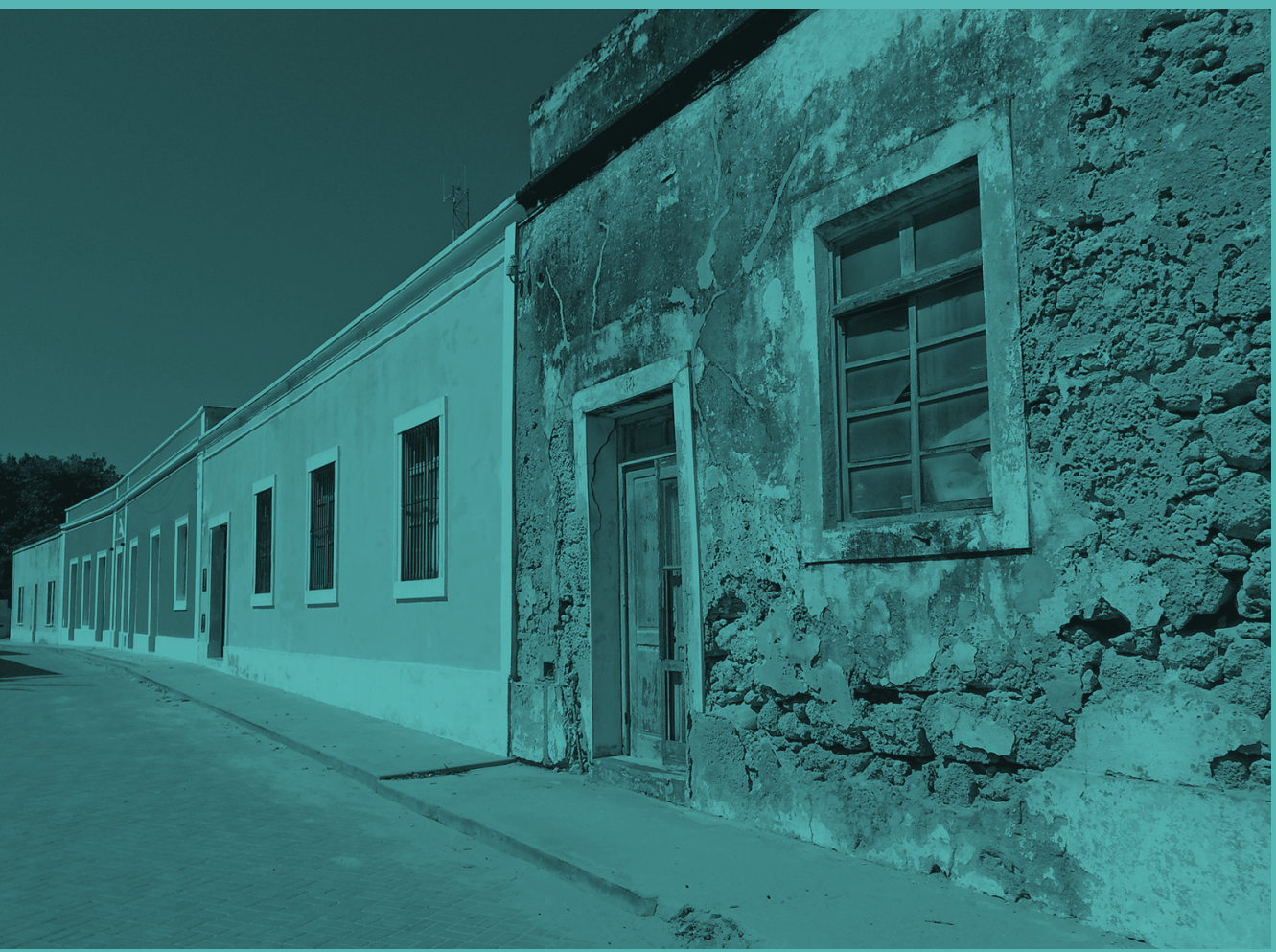


Como estratégia integrada de salvaguarda e preservação do património cultural é ainda importante referir, de forma sintética, a experiência indiana, cujos cinco princípios foram expressos por Ambika Soni (2008), respetiva Ministra da Cultura e Turismo, que aqui partilhamos:

$1^{\circ}$ o património é um recurso e um activo valioso. Não há contradição entre a preservação do património e o desenvolvimento; $\mathbf{2}^{\circ}$ uma parceria entre a sociedade civil, em geral, e as comunidades locais pode ajudar a criar apego e sentido de pertença quanto ao património e à sua preservação. A educação e o trabalho de consciencialização são instrumentos valiosos para tal; $\mathbf{3}^{\circ}$ a mitigação das carências financeiras exige abordagens criativas e determinadas. A criação de parcerias de diversas naturezas, nomeadamente público-privadas pode ser um caminho fecundo, envolvendo-se instituições públicas, empresas e outro tipo de organizações na angariação de fundos para atividades conjuntas de preservação do património, bem como a criação de um Fundo Nacional para o património Cultural que acolha tais iniciativas pode ser uma via; $4^{\circ}$ o papel fundamental do governo deve centrar-se no desempenho do seu papel de catalisador da atividade de preservação do património, através de políticas e medidas legislativas adequadas, bem como de mecanismos de controlo e preservação dos monumentos e sítios não protegidos e em perigo; $\mathbf{5}^{\mathbf{0}}$ a escassez de especialistas e mão-de-obra no domínio da preservação e da gestão dos recursos culturais exige a tomada de medidas específicas de capacitação institucional e de formação especializada.

Nenhum destes princípios de estratégia está em contradição com aquilo que está definido para o país (Macamo, 2009). Trata-se de consolidar, completar, articular, operacionalizar e tornar sustentável o processo, através dos mecanismos legais adequados, bem como através da divulgação e participação do máximo de atores interessados.

Um elemento importante no âmbito da preservação do património edificado é a dimensão colaborativa que se consiga obter, fazendo com que, para além do Estado, participem igualmente organizações da sociedade civil, empresas públicas e privadas, associações, grupos 
de cidadãos e outros. Isto permite descentralizar as atividades de salvaguarda e proteção, reservando-se às instituições do Estado o papel regulador, promotor, mediador, encorajador e, inclusivamente, de premiação das iniciativas autorizadas de preservação do património cultural pelos diferentes agentes sociais.

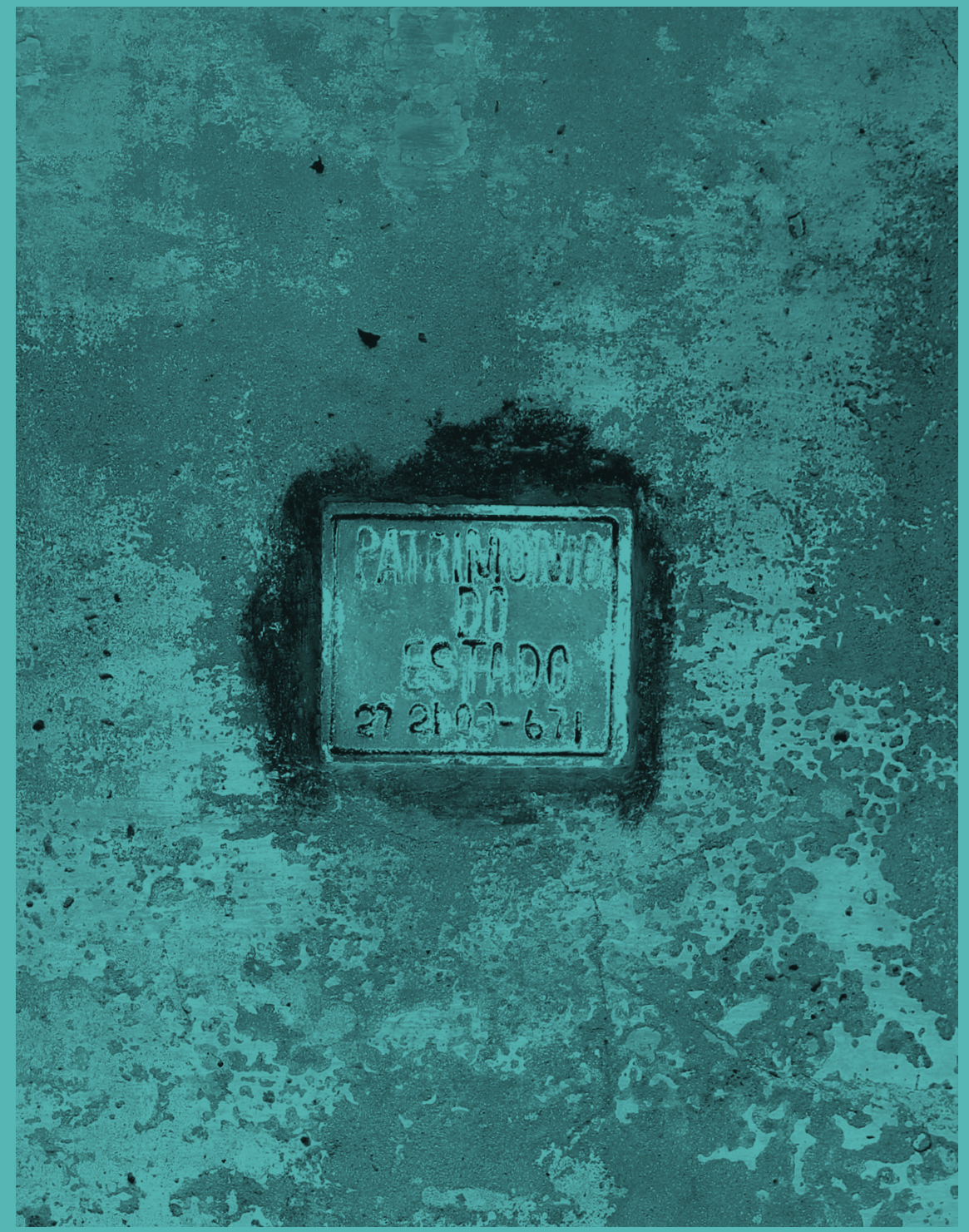




\section{REFERÊNCIAS BIBLIOGRÁFICAS}

BATTLE, Stephen; STEEL, Tony (2001), Conservation and Design Guidelines for Zanzibar Stone Town. Tanzania: Aga Khan Trust for Culture e Unesco, Relatório/manual de boas práticas. Consultado a 20.03.2009, em http:// www.archnet.org/library/documents/one-document.jsp?document_ $i d=9483$.

BELTRÃO, Ana Raquel (2002), "Patrimônio cultural: novas fronteiras", Prim@ Facie, ano 1, n. ${ }^{\circ}$ 1. Consultado a 03.04.2009, em http://www.estig. ipbeja.pt/ ac_direito/artigo_3.pdf.

BRUSCHI, Sandro; SONDEIA, Benjamim (coords.) (2003), Inhambane: elementos de história urbana. Maputo: Edições FAPF, Universidade Eduardo Mondlane

CARRILHO, Júlio (2005), Ibo, A casa e o tempo. Maputo: Edições FAPF, Universidade Eduardo Mondlane.

CARRILHO, Júlio et al. (2000), Um Olhar para o habitat informal moçambicano: de Lichinga a Maputo. Maputo: Edições FAPF, Universidade Eduardo Mondlane.

CARRILHO, Júlio et al. (2005), Era uma vez uma palhota... História da casa moçambicana. Maputo: Edições FAPF, Universidade Eduardo Mondlane.

CHAVEZ, Roberto et al. (2002), Cultural Heritage \& Slum Upgrading. World Bank's Experience and good Practice. Massachussetts: MIT.

COSTA, Aline de Caldas (2007), Reflexões sobre Cultura e Bens Simbólicos: abordagens sobre produção cultural e poder social. Trabalho apresentado no III ENECULT - Encontro de Estudos Multidisciplinares em Cultura, realizado entre os dias 23 a 25 de maio de 2007, na Faculdade de Comunicação/UFBa, Salvador, Brasil. Consultado a 05.04.2009, em: www.cult.ufba.br/enecult2007/AlinedeCaldasCosta.pdf.

Decreto n. ${ }^{\circ}$ 54/2016, de 28 de novembro que aprova o Regulamento sobre a Classificação e Gestão do Património Edificado e Paisagístico da Ilha de Moçambique. Boletim da República n. ${ }^{\circ} 142$.

Decreto n. ${ }^{\circ}$ 55/2016, de 28 de novembro que aprova o Regulamento sobre a Gestão de Bens Culturais Imóveis. Boletim da República n. ${ }^{\circ} 42$ (I).

Direcção Nacional de Património Cultural (1993), Definição de Procedimentos inerentes à Protecção do Património Edificado Classificado. Maputo: Ministério da Cultura e Juventude, Direcção de Monumentos e DNPC (documento orientador, de 30 de junho de 1993, com matéria ainda 
não legislada).

EGAN, Valerie (2010), Post-Colonial Politics and Cultural Heritage. Egyptian Repatriation Requests and European Museums, Master's Research Capstone. Oregon: University of Oregon.

FERNANDES, José Manuel (coord.) (2011), África. Arquitectura e Urbanismo de Matriz Portuguesa. Lisboa: Caleidoscópio e Universidade Autónoma de Lisboa.

FONSECA, Alice Registro; DÓRIA, Renato Palumbo (2008), Definindo o valor histórico: uma reflexão sobre património. Consultado a 05.04.2009, em http://www.ic-ufu.org/anaisufu2008/PDF/IC2008-0089.PDF.

FREY, Pierre (2010), Learning from Vernacular. Towards a New Vernacular Architecture. France: Actes Sud.

FRONER, Yacy Ara (2002), Patrimônio Histórico e modernidade: construção do conceito a partir da noção de revitalização de sítios, monumentos e centros urbanos. Consultado a 04.04.2009, em: http://www.patrimoniocultural.org/OLINDA2002/TRABALHOSSIMPOSIO/ YACYARAFRONER.HTML

GRAHAM, Brian; HOWARD, Peter (eds.) (2008), The Ashgate Research Companion to Heritage and Identity. England and USA: Ashgate Publishing Limited.

ICOMOS (1972), Resolutions of the Symposium on the introduction of contemporary architecture into ancient groups of buildings. Budapest: 3rd ICOMOS General Assembly.

LAGE, Luís et al. (coords.) (2010), Inventário do Património Edificado da Cidade de Maputo - Catálogo de Edifícios e Espaços propostos para Classificação. Maputo: Edições FAPF, Universidade Eduardo Mondlane.

LAGE, Luís et al. (2012), Maputo - Património Arquitectónico. Lisboa: Caleidoscópio.

LAGE, Luís et al. (2013), Beira - Património Arquitectónico. Lisboa: Caleidoscópio.

Lei n. ${ }^{\circ}$ 10/88 de 22 de dezembro, que determina a proteção legal dos bens materiais e imateriais do património cultural Moçambicano. Boletim da República $n{ }^{\circ} 50$ (I).

LINO, Raul (1992), Casas Portuguesas. Alguns Apontamentos sobre o Arquitectar das Casas Simples. Lisboa: Edições Cotovia.

LIRA, Sérgio (1999), Políticas museológicas e definição do conceito de Património: da norma legislativa à prática dos museus. Águas Santas. 
Consultado a 15.04.2009, em

http://www.ufp.pt/slira/artigos/coloquioapomnov99.htm.

LOPES, Flávio (2012), Património Arquitectónico e Arqueológico. Noção e Normas de Protecção. Lisboa: Caleidoscópio.

LOPES, Flávio; CORREIA, Miguel Brito (2014), Património Cultural. Critérios e Normas Internacionais de Protecção. Lisboa: Caleidoscópio.

MACAMO, Solange (2009), Politica de monumentos. Proposta. Maputo: Conselho de Ministros.

MENEGUELLO, Cristina (2000), A preservação do patrimônio e o tecido urbano. Parte 1. A reinterpretação do passado histórico (1). Consultado a 13.09.2017, em

http://www.vitruvius.com. br/arquitextos/arq000/esp007.asp.

Ministério da Educação e Cultura/ Direcção Nacional de Património Cultural

(2008), Classificação do Património Cultural Nacional. Maputo:

Ministério da Educação e Cultura e DNPC (documento em discussão).

Ministério da Educação e Cultura/ Direcção Nacional de Património Cultural (2009), Política de Monumentos. Maputo: Ministério da Educação e Cultura e DNPC (documento em discussão).

Plano de Urbanização da Vila do Ibo (2008). Pemba: Governo da Província de Cabo Delgado.

Plano Parcial de Urbanização da Baixa de Maputo (2015), Regulamento de Protecção de Bens Culturais Imóveis. Maputo: PROMAPUTO II.

ROSSA, Walter (2015), Fomos Condenados à Cidade. Uma década de Estudos Sobre Património e Urbanismo. Coimbra: Imprensa da Universidade de Coimbra.

ROSSA, Walter; RIBEIRO, Margarida Calafate (orgs.) (2015), Patrimónios de Influência Portuguesa: modos de olhar. Coimbra, Lisboa e São Paulo: Imprensa da Universidade de Coimbra, Fundação Calouste Gulbenkian e Editora da Universidade Federal Fluminense.

Secretaria de Estado da Cultura de Moçambique; Arkitektskolen i Ãrhus, Danmark (1986), Ilha de Moçambique, relatório - Report. Moçambique e Dinamarca: Secretaria de Estado da Cultura e Arkitektskolen i Ãrhus. SERRA, Carlos (2015), "Introdução: africanidade que luta" in O que é Filosofia Africana?, Cadernos de Ciências Sociais. Lisboa: Escolar Editora.

SIMONE, AbdouMaliq (2004), For the City Yet to Come. Changing African Life in Four Cities. Durham and London: Duke University Press.

SONI, Ambika (2008), An integrated approach is required for a successful 
movement of heritage preservation and promotion. Comunicação feita na Asian Regional Cooperation Conference, representando o Ministério do Turismo e Cultura da Índia. Consultado a 02.12.2008, em http://www.ifacca.org/national_agency_news/2008/12/02/integratedapproach-required-successful-movement-h/

VELOSO, António Matos et al. (2008), João José Tinoco - Arquitecturas em África. Lisboa: Livros Horizonte.

VICENTE, Joaquim et al. (2002), Antigo Bairro Militar de Maputo. Maputo: Edições FAPF, Universidade Eduardo Mondlane. 

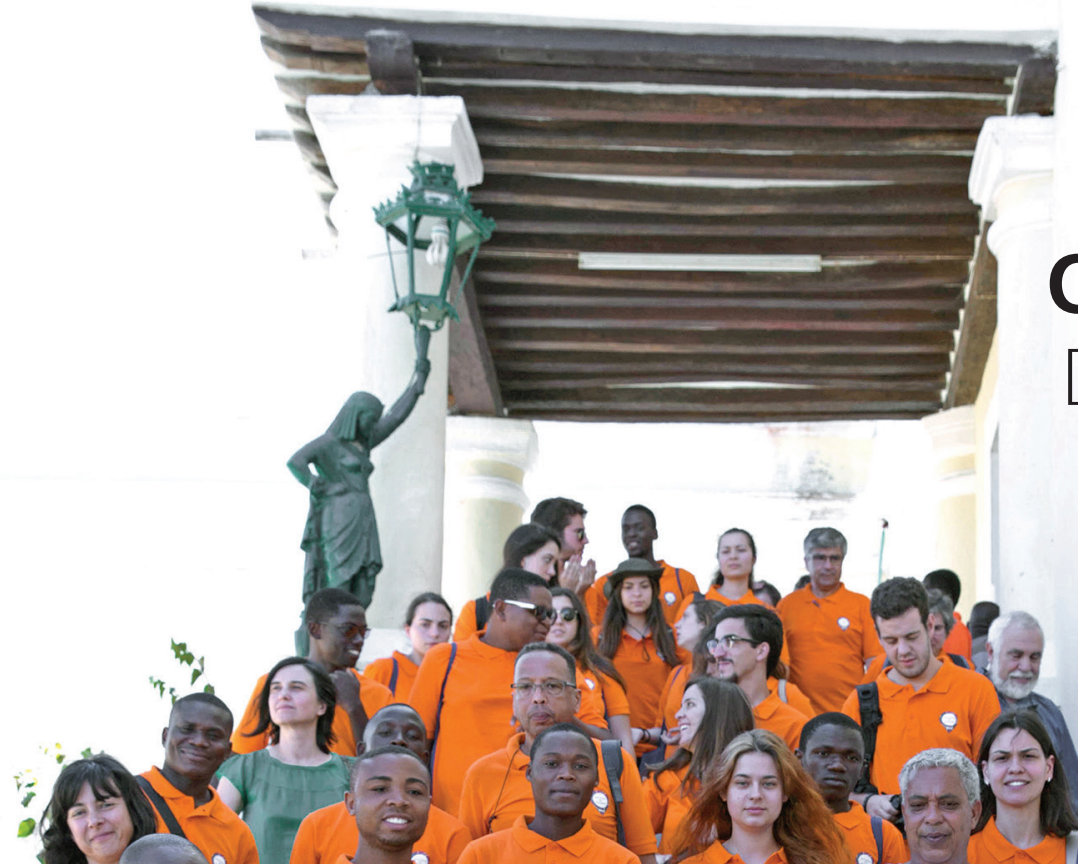

Oficinas [caminhos]

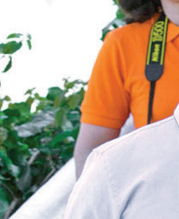

\section{fin}





\title{
INTRODUÇÃO
}

\author{
Walter Rossa
}

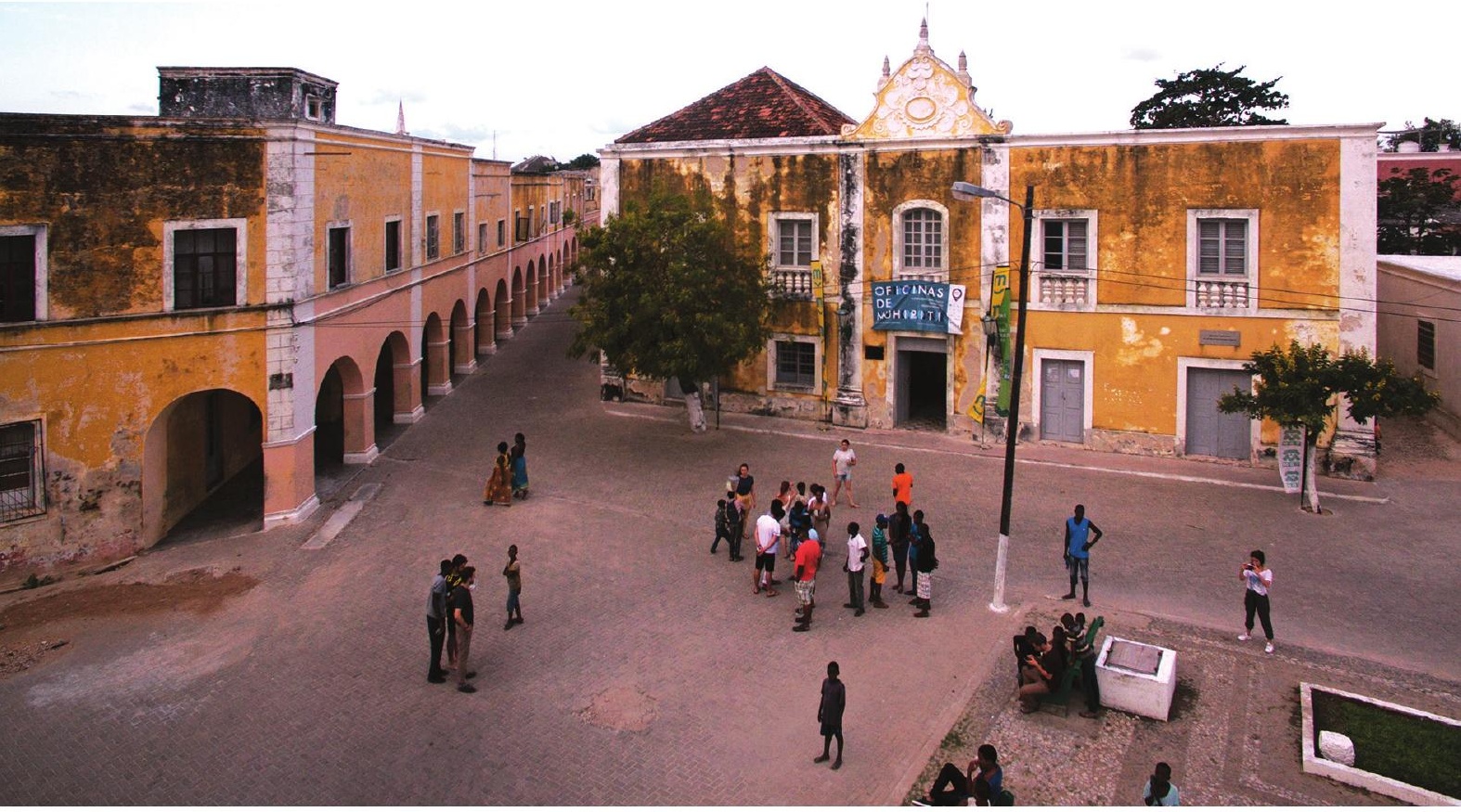

\section{A UNIVERSIDADE FOI À ILHA. TERÁ FICADO?}

As oficinas foram, necessariamente, o motor da ação que levou à produção deste livro. Não faz sentido repetir aqui o que foi registado nos dois textos de apresentação (dos organizadores e dos responsáveis da UniLúrio) sobre o que levou à sua estruturação e montagem, bem como o objetivo estratégico geral do projeto que, contudo, se resume à expressão simples do seu título, mas que agora reformulo para mais o reforçar: potenciar a riqueza do património cultural da Ilha de Moçambique de forma a proporcionar uma boa vida aos seus cidadãos e, por isso mesmo, dotar esse ativo estratégico de sustentabilidade e resiliência. 
Não era uma experiência nova para todos nós pois, entre outros, eu próprio já participei em vários workshops deste género, tendo coorganizado um em Arzila (Marrocos) e dois em Cabo Verde (Mindelo e Santa Maria), sendo que de um dos últimos também resultou uma publicação. Todavia, nenhum deles tinha as condições de enraizamento da universidade que este teve e tem. Também em nenhum deles foram tão claramente assumidos os princípios de ciência aberta e ensino aberto.

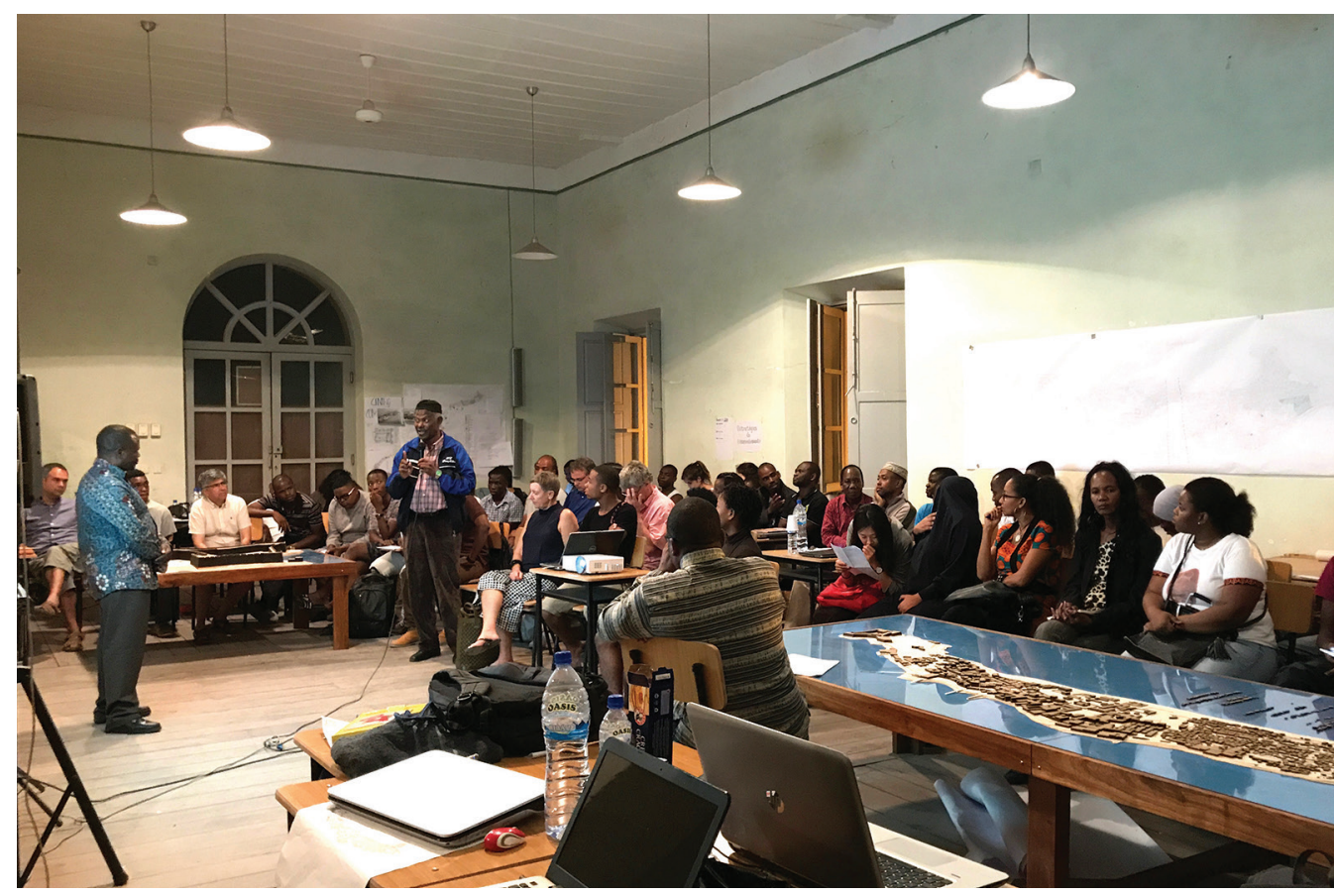

A fórmula metodológica consistiu na criação de 6 equipas de trabalho, oficinas, cada uma responsável por uma tarefa específica com ligações sinérgicas aos outros, asseguradas no programa por vários momentos de cruzamento, pela realização do trabalho num só espaço e, claro, pela coordenação e especialistas convidados. Cada oficina foi integrada por 2 a 3 alunos dos anos finais de graduação de cada um dos cursos de arquitetura das universidades de Lúrio e de Coimbra, e por um professor ou, pelo menos, doutorado, com formações disciplinares diversas, de cada universidade (arquitetos, historiadores, geógrafos, urbanistas), que coordenaram a respetiva oficina. 
O potencial obstáculo da falta de vínculos e hábitos de trabalho anteriores entre os 49 participantes, ou os 7 a 8 membros de cada equipa, constituiu-se numa vantagem pelo ritmo imposto pelo apertado calendário (e, diga-se, saudável concorrência implícita) de pontos de situação abertos à participação pública, e pela determinação de uma exposição final de síntese. Tudo isso pressionou a superação de eventuais divergências e a criação de um fantástico ambiente de trabalho. Por outras palavras, com apenas 9 dias completos para cumprir as tarefas, não houve tempo para conflitos ou expressões de idiossincrasias.

\section{Foram cruciais:}

i) a preparação meticulosa da logística e da acessibilidade de materiais, suportes e ferramentas;

ii) a montagem gradual e coerente de uma imagem de marca para o evento, o que agora se propõe continuar a fazer para a llha, acabando por corporizar, pós-evento, mais um tema-oficina;

iii) a disponibilização de todo o tipo de dados sobre as questões abordadas por todas as oficinas;

iv) um texto de encomenda da missão conciso e claro (que aqui também publicamos) sobre o desafio colocado a cada oficina, lançado e discutido com antecedência por todos os participantes;

v) o conjunto de conferências proferidas por especialistas moçambicanos, sempre com foco na llha, sobre questões como planos de conservação e gestão de património, gestão de meio ambiente e resíduos, arqueologia subaquática, caracterização sociológica e desafios;

vi) o trabalho de campo (onde a interação com as comunidades, além de muito produtivo, foi humanamente compensador), complementado por visitas públicas e acesos debates em pontos de situação abertos a todos.

Foi ainda relevante a explicação sobre as ações realizadas pela Cooperação Portuguesa com a UCCLA (União das Cidades Capitais de Língua Portuguesa) no âmbito do projeto Cluster da Cooperação Portuguesa para Moçambique, lançado em 2009. Outros dois aspetos que também contribuíram de forma sensível para a criação do profícuo ambiente de 
trabalho entre os professores e alunos, convidados e a população, foram: a montagem das duas maquetas (agora em exposição no (EDIM) ao longo do evento e no seio do espaço onde decorreu, o que está bem patente nas fotografias das sessões públicas, pois todas tiveram lugar em torno dessas, também, oficinas; a realização de quase todas as refeições em comum no pátio do edifício de trabalho, a Casa Girassol.

Conforme já inicialmente registado e profusamente ilustrado ao longo do livro, o Oficinas terminou em festa, com a abertura da exposição provisória de resultados num fim de tarde e, na manhã seguinte, uma regata de dhows (barcos tradicionais), ambos momentos com expressivo envolvimento de habitantes da região e da Ilha. Construir confiança pública entre os agentes e a população, e desenvolver a autoestima é difícil, leva muito tempo e exige persistência.
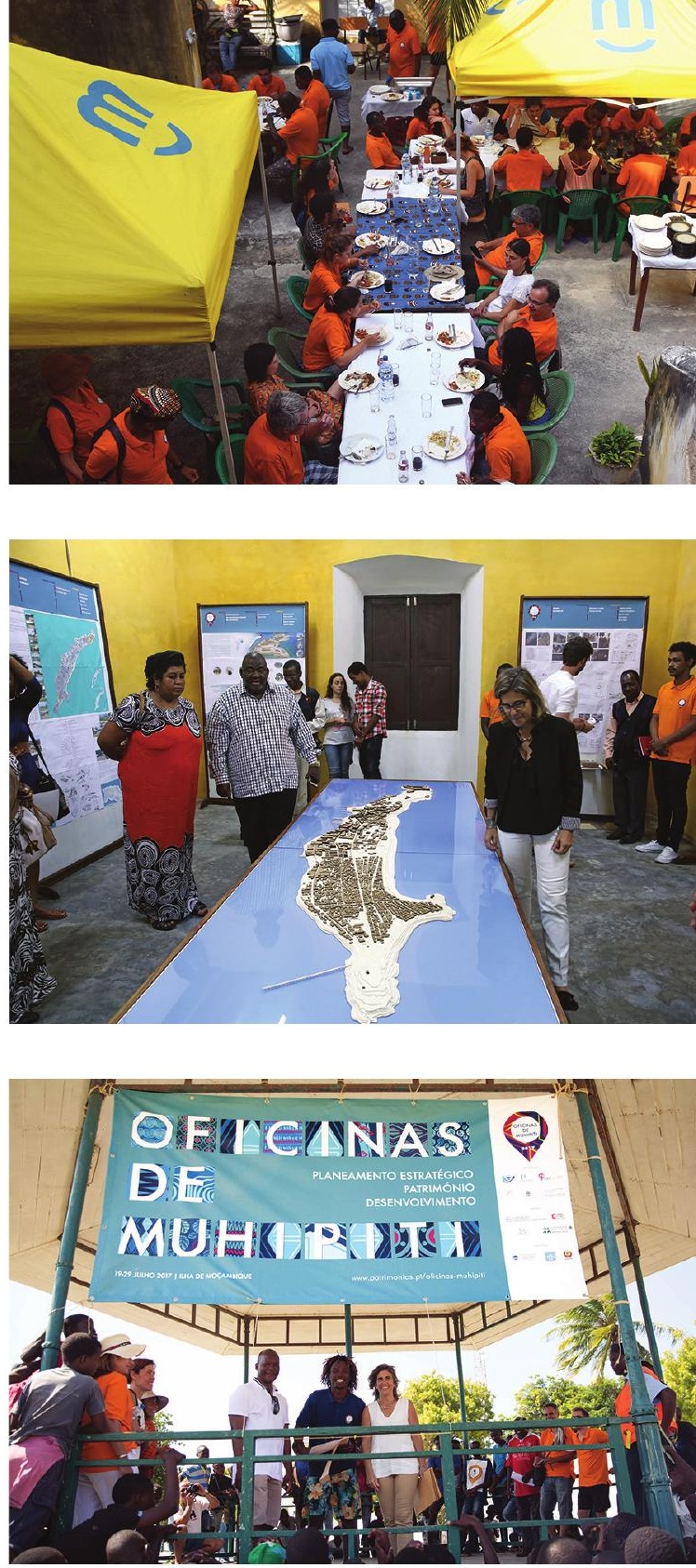

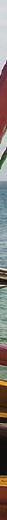


Com efeito, percebemos e estabelecemos desde o início que seria muito importante, não só envolver a população tanto quanto possível, mas também dar-lhes algo de concreto, um sinal de que realmente não estávamos lá apenas para perguntar coisas, invadir a privacidade dos seus lares, pensamentos e desejos, para lhes dizer o que eles deveriam fazer (na verdade, principalmente o que não convém fazerem), como muitos outros fizeram durante as últimas décadas, com igual boa vontade e, provavelmente, maiores competências em políticas patrimoniais. Porém, no final, a população geralmente mantém a ideia de que, para esses especialistas, o património é mais importante do que eles, um resultado e uma imagem de uma academia distante que, definitivamente, queremos evitar.

Por tudo isso, tendo em conta o desafio da UniLúrio de dar vida ao CEDIM, criado em 2011 e ainda em estado embrionário, e percebendo que será uma tarefa ciclópica implementar o objetivo inicial de nele montar uma biblioteca e arquivo de cópias físico e útil, foi decidido enquadrá-lo não apenas como uma base de dados virtual, mas também como plataforma operacional de diálogo entre a UniLúrio, a população e os agentes públicos. Por outras palavras, o CEDIM deve tornar-se a plataforma de investigação \& desenvo/vimento de serviços e transferências de conhecimento entre a UniLúrio e a llha. O primeiro passo foi capacitá-lo como destino e repositório dos resultados do Oficinas e continuidade dos respetivos trabalhos.

Não pode, porém, estabelecer-se qualquer confusão entre esses resultados e a consubstanciação de uma premente estratégia de conservação patrimonial, de gestão ou de outros planos e regulamentos para a Ilha, que somente os órgãos públicos governamentais, regionais ou municipais podem e têm competências para desenvolver e implementar (ver os três primeiros textos da parte MUHIPITI). Não é uma competência da universidade, mas esta pode empreender, especulativamente, simulação e estímulo, e disponibilizar os seus resultados para discussão e integração nas soluções institucionais já avançadas. Isso e, claro, no âmbito da sua progressiva implantação na Ilha, a UniLúrio pode pautar a sua ação pelo pensamento que ela própria vai desenvolvendo e confrontando com a opinião pública e institucional. Apontar e trilhar de alguns caminhos... 


\section{OFICINA A OFICINA}

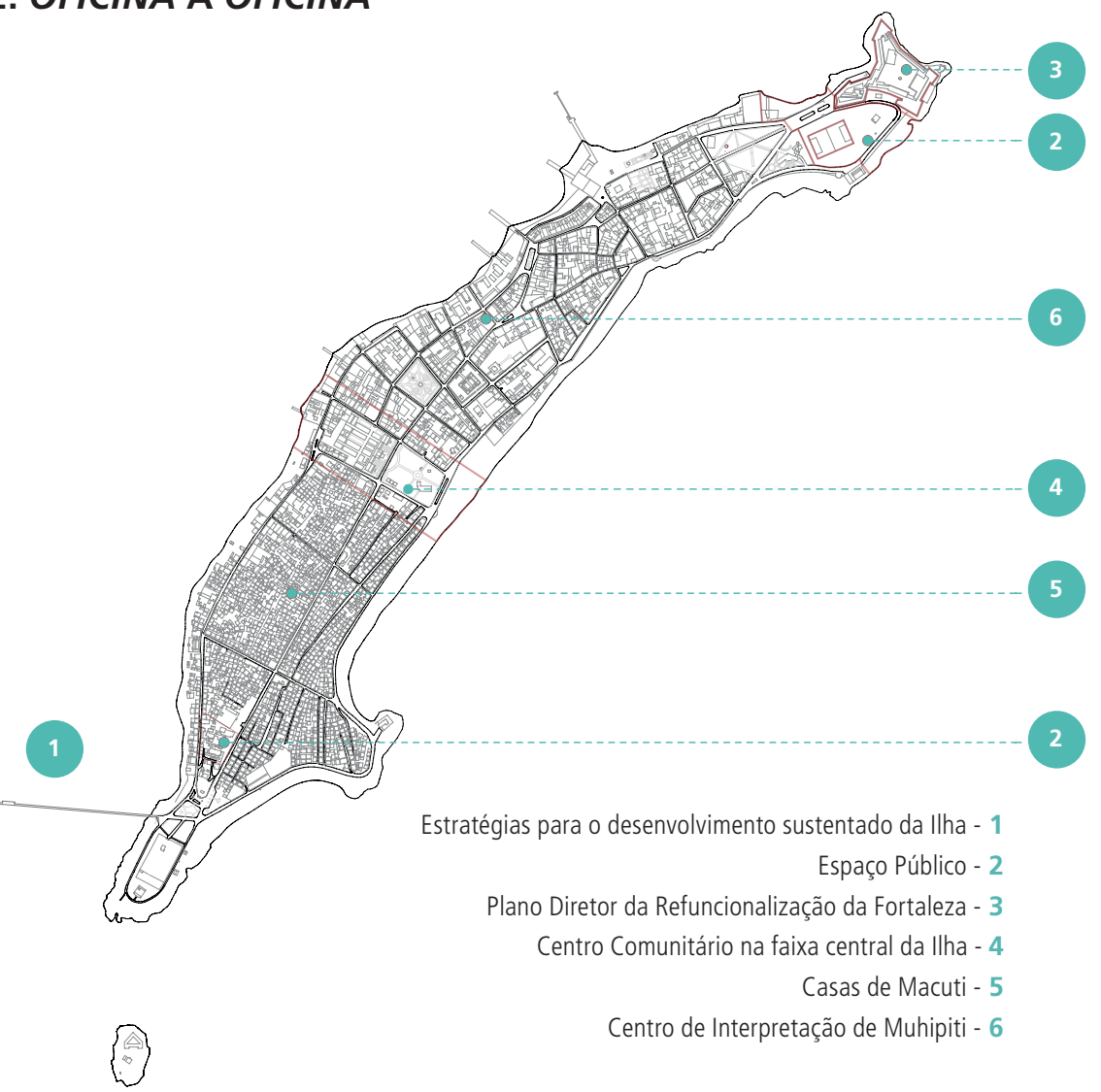

Uma vez clarificado o contexto teórico, prático e institucional cabalmente apresentado até aqui, caberá agora ao leitor apreciar os resultados alcançados pelo Oficinas, oficina a oficina. Nesse sentido, acrescento ainda algumas breves notas, muito em função da missão inicialmente distribuída a cada um, cujo texto é publicado em caixa própria no início de cada um dos relatórios elaborados pelos respetivos professorescoordenadores. Ficamos, assim, dotados de condições para a avaliação das respostas em função das encomendas, incluindo os incontornáveis e, por vezes, bem-vindos desvios, catalisados pela realidade concreta dos objetos e limitações das condições oferecidas para o desenvolvimento dos trabalhos. 
A simulação de planeamento estratégico realizada pelo Oficinas, também sob as palavras-chave património e desenvolvimento, tem dois polos opostos por entre os seus seis temas oficinas, ambos com um alcance holístico e métodos inter e transdisciplinares, mas propósitos operacionais absolutamente diversos. Se a oficina Estratégias para o desenvolvimento sustentável da llha esteve diretamente à procura da formulação clara de ações que podem/ devem ser inscritas em planos de ação estratégica com perfis de gestão integrada, a oficina Centro de Interpretação de Muhipiti [CIM], teria de procurar orientações para estabelecer esse centro como uma plataforma de diálogo privilegiado e permanente sobre a llha entre todos os agentes e as partes interessadas no local. Esperamos que seja claro que eles são absolutamente complementares, mas se podemos assumir que a missão e resultados da primeira não precisam de explicação além do seu próprio relatório, o mesmo não acontece com a segunda.

A criação do CIM foi empreendida como uma decisão chave no âmbito da agenda do CEDIM/UniLúrio. Não é algo inspirado em museus ou similar, mas numa estrutura dinâmica que deverá ter como principal objetivo um diálogo permanente com a população da Ilha. Interpretação da e para a população, não um centro de boasvindas ou explicação para os visitantes. Claro que, se os conteúdos se tornarem reais, atualizados, considerados fidedignos pela população, tornar-se-ão também a mais preciosa concentração de dados sobre a Ilha para os visitantes. Será uma estrutura polinuclear articulada com as mais diversas expressões culturais, dos grupos de tufo ao Museu da Ilha. Está-se a trabalhar na definição do layout e conteúdos do primeiro espaço, que se espera abrir até ao fim de 2018, substituindo na sala do CEDIM a exposição dos resultados do Oficinas, agora montada no edifício Municipal. Mas algum material da futura exposição já lá está. Refiro-me às duas maquetas que o Oficinas construiu antes e durante o evento, uma da Ilha à escala 1:1.000, outra da Fortaleza de São Sebastião à escala 1:200. Estes processos de construção foram também um levantamento e uma investigação, e a sua oferta à Ilha foi muito bem recebida no compromisso da UniLúrio com a llha e o seu desenvolvimento. 

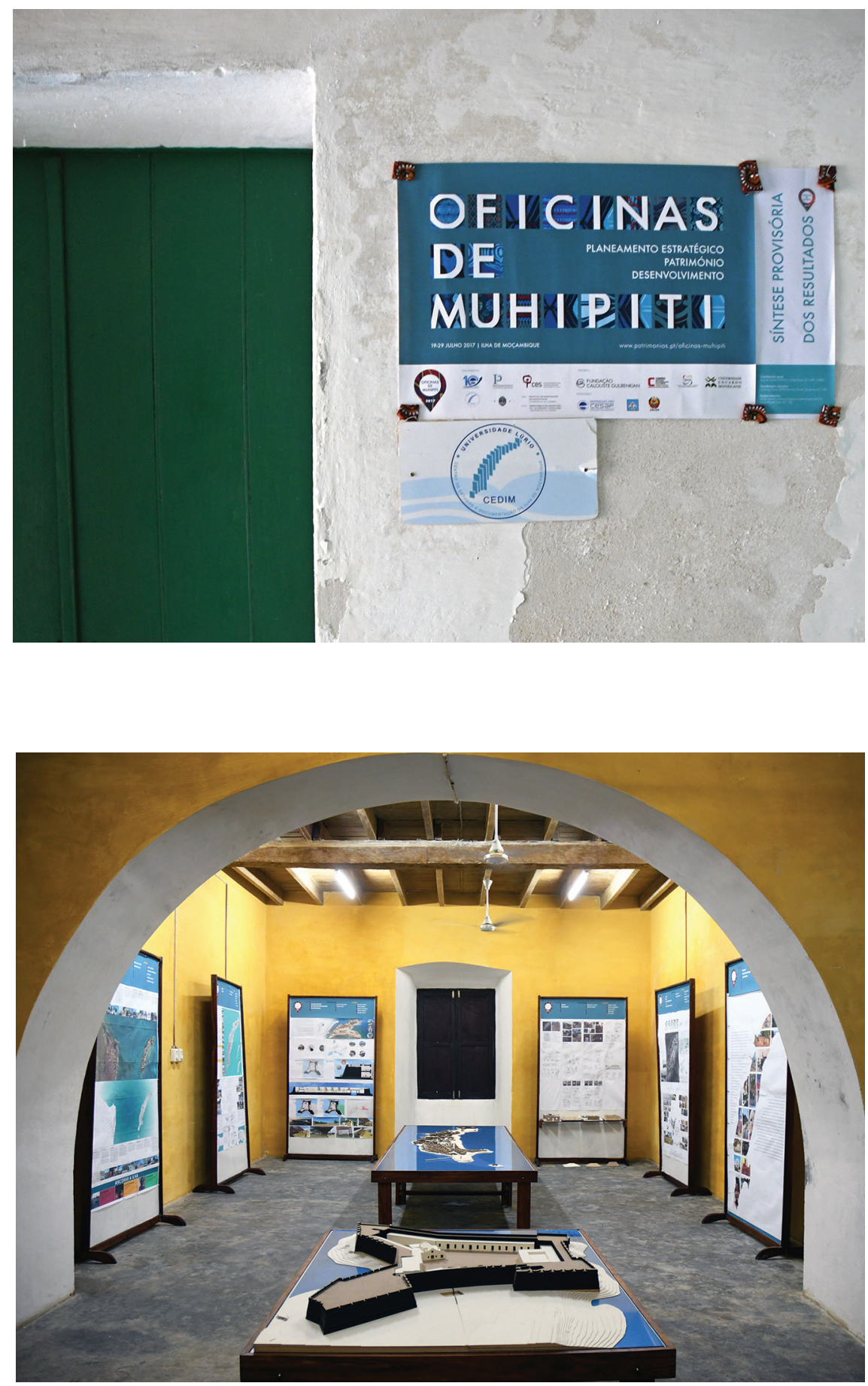
Regresso ao tema da oficina Estratégias para o desenvolvimento sustentável da Ilha para justificar e apresentar a inserção pós-evento de uma outra oficina, a Marca-lugar Muhipiti que, como antes apontei, é uma emanação da produção do evento. Com efeito, desde o início dedicámos algum cuidado à criação de uma imagem-marca para o Oficinas, que não só lhe desse visibilidade, como contribuísse para a sua coesão e coerência. Era inevitável que, mais cedo ou mais tarde, esse trabalho, num contexto global mais vanguardista de orientações estratégias para o desenvolvimento urbano sustentável, acabasse por impor o esboço de uma proposta para a criação de uma estratégia de marca para a Ilha que, não só a projete para o exterior, como estruture e oriente internamente a sua fruição. Resolvemos desafiar a equipa que nisso trabalhou, constituída por moçambicanos que residiram e bem conhecem a llha, a ousar produzir um registo que possa desencadear a concretização de mais esse desígnio estratégico, o que publicamos no fim desta parte do livro. A opção de manter a designação Muhipiti nesse ensaio é das coordenações do evento e deste livro, o que é explicado no início desse texto.

As outras quatro oficinas tiveram escopos mais concretos e áreas de intervenção delimitadas. A do Espaço público e do Plano para centro comunitário na faixa central da Ilha abordaram os espaços públicos (sempre uma questão de grande relevância numa estrutura urbana) e as do Plano diretor da refuncionalização da fortaleza e Casas de macuti (para programas específicos de construção). Ambos os pares denunciam a divisão estrutural do layout da llha entre a cidade de pedra e cal e a cidade de macuti. Embora isso se tenha esvanecido étnica e racialmente, continua a ser formal e urbanisticamente claro, como o é no dia a dia da última, uma área urbana viva sob um enorme e inevitável processo de transformação, não apenas pela pobreza dos seus habitantes, mas principalmente pelo seu layout colonial de cidade dos não cidadãos, com toda a falta de infraestruturas básicas que daí resultaram. A cidade de pedra e cal, em tempos o lugar dos negociantes, comerciantes e ocupantes coloniais, é hoje um equilíbrio entre a sede dos órgãos públicos, equipamentos turísticos e uma grande quantidade de ruínas e edifícios vazios. Apenas uma pequena parte da população aí vive, em muitos casos em piores condições do que a da cidade de macuti. 
A oficina do Espaço Público foi dotada da liberdade de selecionar os espaços de intervenção à medida que melhor os identificasse, levando em consideração três aspetos: a) casos de estudo eleitos de ambas as áreas; b) estabelecimento de conexão com outros projetos de espaços públicos da llha (como o que está a ser implementado pelo Conselho Municipal em conjunto com o Cluster da Cooperação Portuguesa para Moçambique, entre o mercado de Nália e o Paiol); c) o Estudo Preliminar sobre Espaços Públicos da Ilha de Moçambique, elaborado em 2011 pelo Centro de Estudos do Património Mundial da Faculdade de Design da Universidade de Minnesota. O trabalho desenvolvido por esta oficina levantou um conjunto considerável de problemas e, mais do que soluções atuais, sugere alguns métodos de abordagem e soluçõestipo. Seria impossível apresentar uma proposta estabilizada dentro da enorme variedade de problemas e extensão da área estabelecida entre a Fortaleza de São Sebastião e o limite construído no norte da cidade de pedra e cal.

A missão da oficina Plano para centro comunitário na faixa central da Ilha passava por redesenhar ou, melhor, reestruturar a área urbana, uma vez que se trata da praça-jardim situada entre o hospital, o litoral oeste, o limite norte da cidade de macuti e o limite sul da cidade de pedra e cal, hoje ocupada com uma escola semiarruinada, restaurantes-cabana, entre outras coisas. Não obstante a realidade caótica, continua a ser o espaço público preferido para os encontros informais dos habitantes, mas também para reuniões políticas, festas comunitárias, etc. O simbolismo e monumentalidade do edifício hospitalar e do espaço público como conexão entre as duas cidades, serão certamente razões para isso. Esta oficina desenvolveu um estudo profundo sobre o significado da comunidade e da identidade do espaço, novas funções desejáveis e cenários de desenho urbano. O mote não passava por um programa de construção, mas o potencial formal e simbólico para um espaço público como centro da cidade.

Conforme mencionado anteriormente, a instalação da nova faculdade da UniLúrio na llha ocorreu em instalações provisórias. É por isso que o lugar definitivo, a Fortaleza de São Sebastião, apesar de algumas intervenções de conservação feitas há alguns anos sob projeto de José Forjaz e financiamento japonês, não prova ser ajustada nem sustentável para uso. Há pouco tempo, a Faculdade de Arquitetura e Planeamento Físico 


\section{NOTA FINAL E PESSOAL}

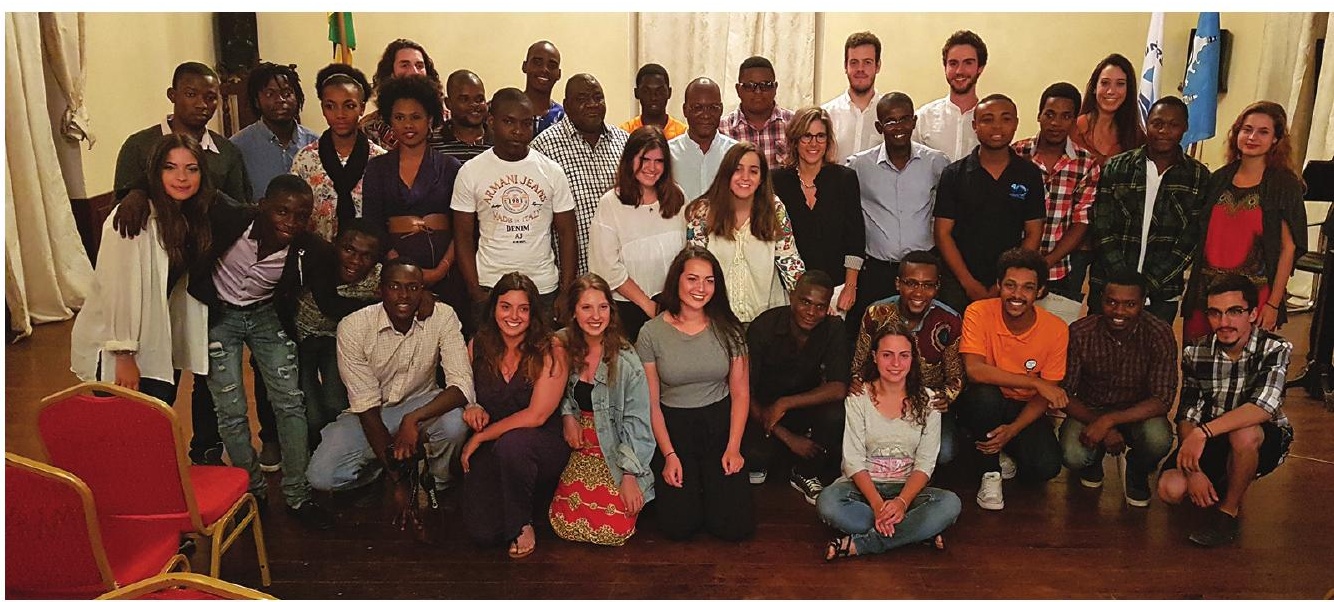

Na África Austral, os conceitos e métodos de conservação do património nascidos no Ocidente raramente chocam com situações como a que encontramos na llha de Moçambique. Não há dúvida de que a inscrição na Lista do Património Mundial há cerca de um quarto de século, evitou a perda dos seus valores culturais mais significativos. Esse marco foi alcançado devido ao empenho de alguns moçambicanos e das autoridades moçambicanas ao mais alto nível. Com o final da Guerra Civil, em 1992, a llha iniciou um lento processo de desocupação, pois o continente oferece mais terra e liberdade de instalação. Mas muitos mantiveram-se e a tímida atualização económica da última década incentivou-os a melhorar as suas condições de vida. Ninguém pode ser culpado por isso. Simultaneamente, a beleza da cidade-Ilha e da Baía de Mossuril atrai gradualmente mais visitantes e surgem novas infraestruturas. É também um processo não reprovável.

Ambos os processos (a melhoria das condições de vida e o desenvolvimento da indústria do turismo), se não harmonizados dentro de um processo integrado de planeamento e gestão com um maior/holístico alcance, levarão certamente à perda dos valores que desencadearam tudo isso. Por outras palavras, não são sustentáveis. Poderia listar mais algumas ações de melhorias não reprováveis em curso nesse território que não são sustentáveis. Poderia também fazer uma lista de dificuldades que devem ser ultrapassadas para permitir 
a implementação de iniciativas de planeamento (corrupção, falta de pessoal especializado em qualquer órgão público com jurisdição de gestão urbana, falta de estatística/recenseamento, etc.), mas quero apenas destacar a inexistência do levantamento cadastral e do registo, crucial para a gestão urbana, incluindo um sistema de receita fiscal pelo qual os órgãos públicos poderiam não só financiar os seus investimentos, mas também fomentar a adoção das suas políticas. Desde a independência moçambicana, em 1975, nunca a Ilha, ponto focal na sua identidade e coesão, esteve tão ameaçada de descaracterização como agora. Todavia os mesmos motivos levam-me a argumentar que é também uma oportunidade estimulante para se tornar um lugar sustentável, resiliente e desenvolvido (os 3 lemas do Sustainable Development Goal 11 e da New Urban Agenda), excelente para viver, descansar e estudar. A universidade tem agora uma enorme responsabilidade nessa mudança. Não só é o mais recente ator público da Ilha, como também possui o conhecimento e a independência necessários para agitar as partes competentes e interessadas, para reverter a restrição das ações inertes de conservação em políticas de planeamento estratégico com uma visão holística. Aliás, recorrendo ao modelo de várias experiências (algumas próximas) bem sucedidas, a UniLúrio tem todas as condições para criar um serviço local de planeamento estratégico e de apoio direto de projeto aos habitantes menos favorecidos. Na realidade o Oficinas só pode ter sido um momento inicial e, como se diz em Moçambique, estaremos juntos! 


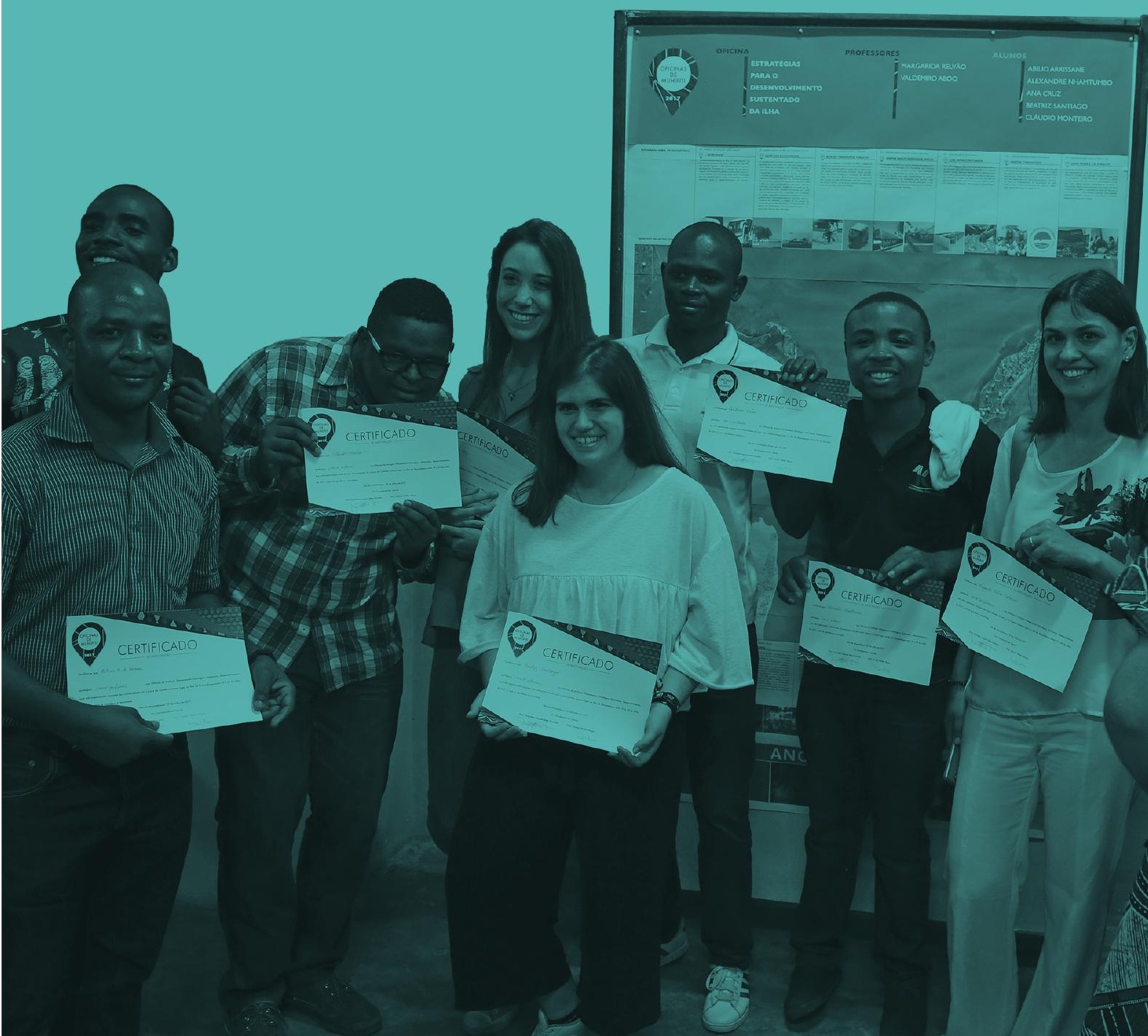




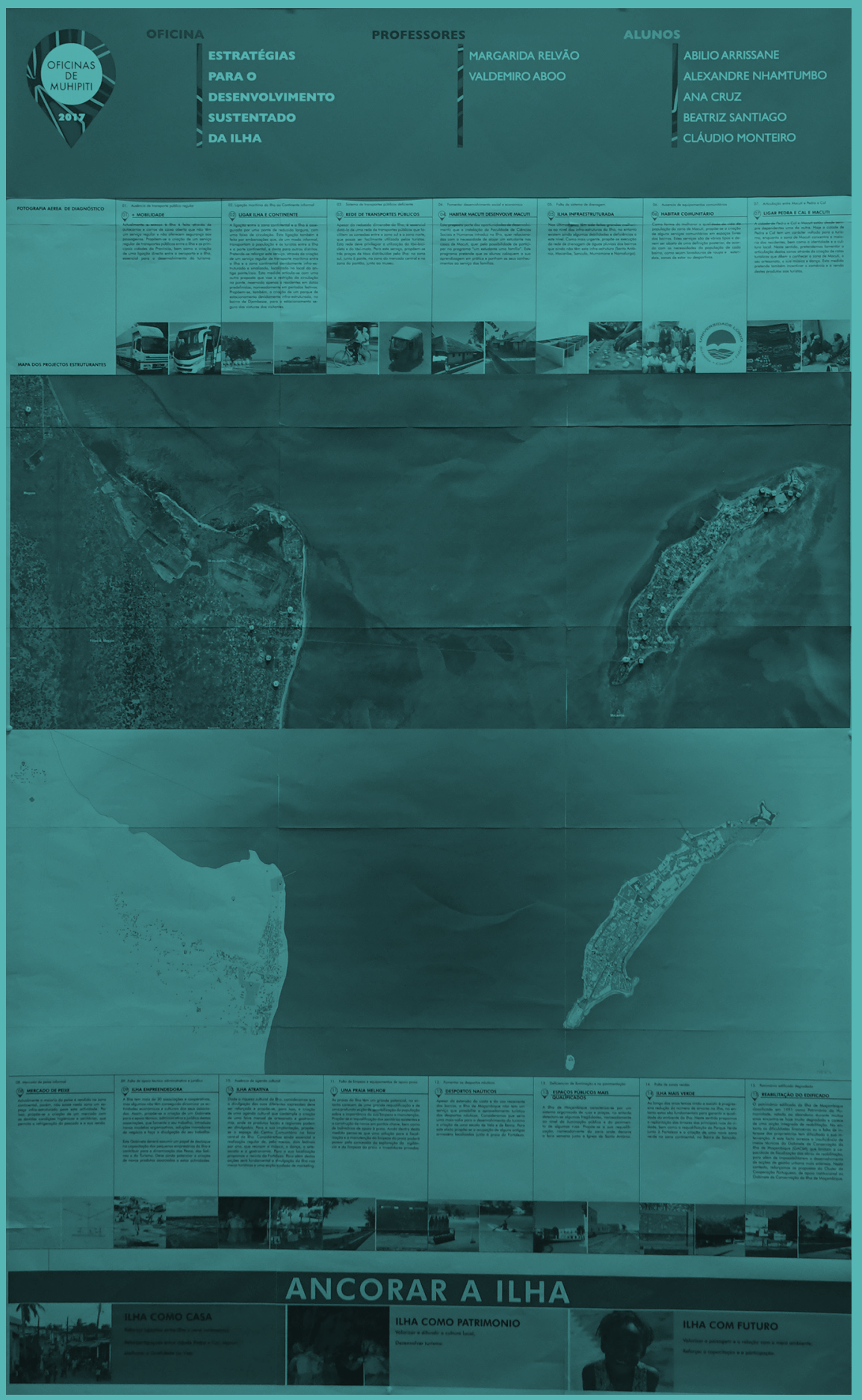




\title{
ESTRATÉGIAS PARA 0 DESENVOLVIMENTO SUSTENTADO
}

\author{
Margarida Relvão Calmeiro \\ Valdemiro Aboo
}

\section{Missão-encomenda previamente formulada}

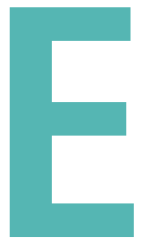

sta oficina tem como missão proceder a uma avaliação (provavelmente através de uma análise SWOT) das dinâmicas em curso no espaço de relação territorial da Ilha, por forma a definir enquadramentos e ações estratégicas vitais, para que a oportunidade constituída pela instalação, em curso, do polo de Ciências Sociais e Humanas da Universidade Lúrio seja potenciada para a definição e instalação da, há muito almejada, definição e implementação de um modelo que promova o seu desenvolvimento sustentado. É necessário conhecer as dinâmicas económicas locais existentes, como a pesca e o turismo, as características, pendularidade, tendências demográficas e da população residente, os rácios e características de visitantes, a localização ou deslocação de serviços e polos de atividade económica, etc. Define-se como resultados mínimos a atingir a definição sintética de um conjunto de ações (equipamentos, infraestruturas, serviços, etc.) e a sua priorização, devendo a indicação dos agentes e potenciais formas de financiamento para cada uma delas funcionar como teste preliminar à sua viabilidade. Dessa forma, os decisores locais poderão dispor de um quadro de referência para a definição das suas políticas 


\section{INTRODUÇÃO}

Esta oficina teve como missão a definição de um conjunto exemplar de ações estratégicas suscetíveis de alavancar o desenvolvimento sustentado da llha, com base numa avaliação das dinâmicas em curso no seu espaço de relação territorial.

A llha de Moçambique, declarada Património da Humanidade em 1991, caracteriza-se por uma grande riqueza cultural, fruto de uma história que remonta ao século VII e inclui influências chinesas, árabes, indianas e portuguesas. Esta diversidade é visível nas tradições, usos e costumes, bem como na língua e no espaço construído. A llha está dividia em duas zonas de morfologia urbana claramente distintas: a cidade de pedra e cal e a cidade de macuti. A cidade de pedra e cal corresponde, grosso modo, à área ocupada pela primeira sede 


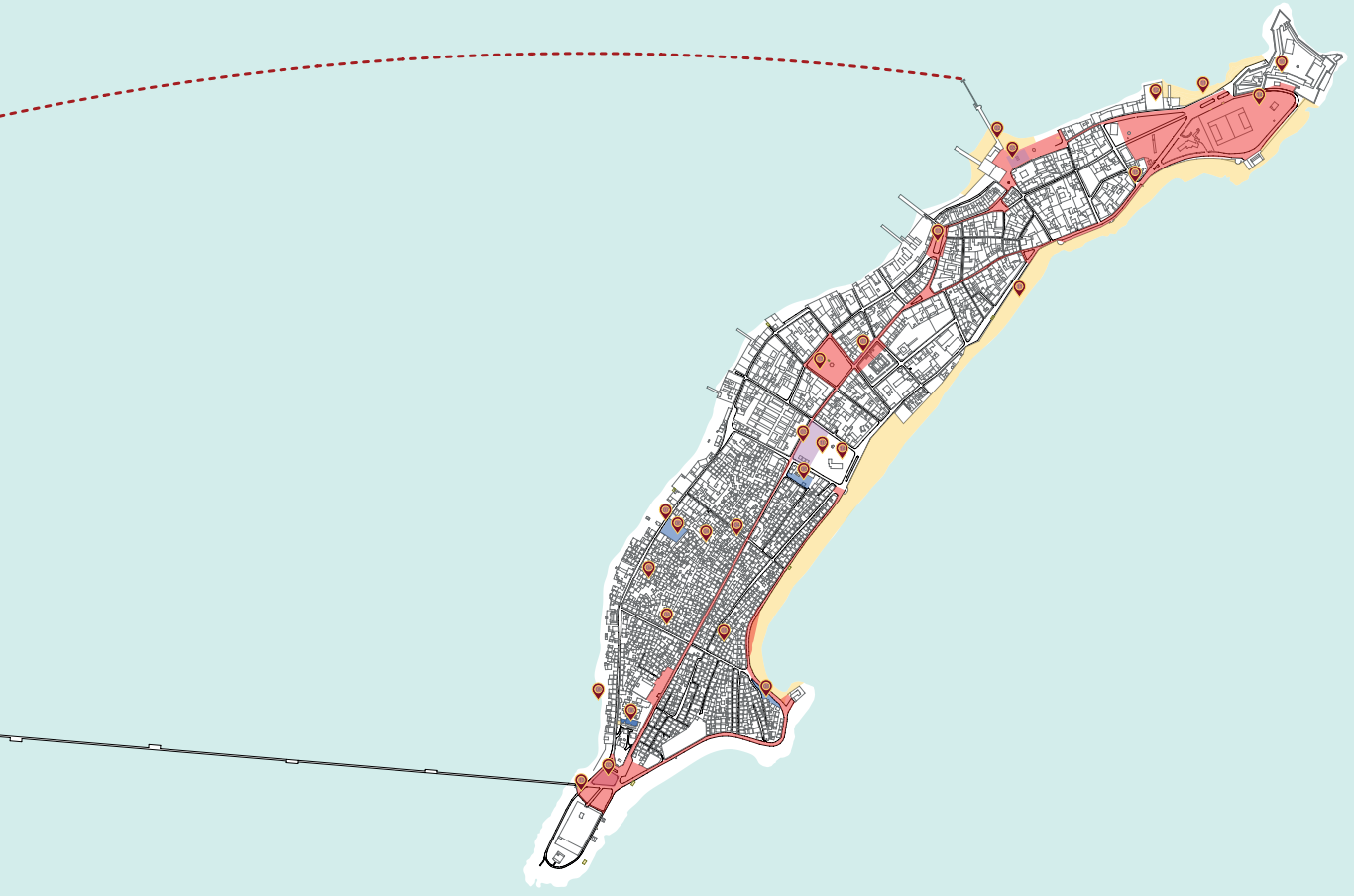

da Colónia Portuguesa entre 1507 e 1898. Por sua vez, a cidade de macuti é a zona mais densamente construída e ocupada, por oposição a grande parte dos edifícios da cidade de pedra e cal, devoluta. Atualmente, pese embora a inscrição na Lista do Património da Humanidade, os vários estudos e projetos já produzidos e a execução de algumas intervenções estruturantes para a llha, existem ainda muitas debilidades, quer ao nível do edificado, quer das infraestruturas e equipamentos públicos. Neste sentido, procurámos definir uma estratégia de planeamento sensível à preservação do património existente, mas fundamentalmente capaz de fomentar o desenvolvimento sustentável, tendo consciência de que no curto espaço de tempo disponível não seria possível mais do que definir um conjunto de ações de valorização, desenvolvimento e projeção da Ilha, materializadas num conjunto de 15 Projetos Estruturantes. 


\section{ENQUADRAMENTO E MÉTODO}

O município da Ilha de Moçambique corresponde não apenas ao território insular, mas também a uma vasta área continental, que tem vindo progressivamente a ser ocupada por novos bairros residenciais, com uma base maioritariamente informal, mas servidos por alguns equipamentos. Para delinear uma estratégia de desenvolvimento integrado, é essencial abranger esse território, pelo que a área da intervenção é todo o Município da Ilha de Moçambique.

Numa primeira fase, foi desenvolvido o estudo de caracterização e diagnóstico do território. Este processo começou antes do início formal do Oficinas, com a recolha e análise de elementos documentais e cartográficos fornecidos pela organização e com o levantamento das dinâmicas económicas e sociais a partir da consulta das Estatísticas do Distrito da Ilha de Moçambique, elaboradas pelo Instituto Nacional de Estatística (INE, 2012).

Ainda nesta fase, mas já no âmbito dos trabalhos na Ilha, seguiuse o reconhecimento efetivo do território, que incluiu o contacto direto com os secretários de cada bairro (figura que legalmente estabelece a articulação entre as entidades municipais e os habitantes de cada bairro), com representantes de algumas associações locais, nomeadamente a Associação dos Pequenos Empresários Hoteleiros da Ilha de Moçambique [APETUR], a Associação Cultural das Mulheres da Ilha de Moçambique [ACUMIM], a Associação Estrela Verde, bem como com alguns empresários de restauração, comerciantes, artesãos e guias turísticos. Complementarmente, foi sendo feita a caracterização urbanística, analisando-se os usos, as infraestruturas e os equipamentos. A concluir esta fase de caracterização, foi elaborada uma análise SWOT de forma a sintetizar e facilitar a leitura e comunicação dos dados apurados.

Este trabalho de reconhecimento direto do território e contacto com as comunidades proporcionou, a toda a equipa, a oportunidade de avaliar critica e rigorosamente a área de intervenção fundamental para a fase que se seguiu: a definição de uma visão de futuro da llha e das respetivas linhas de intervenção estratégica. 


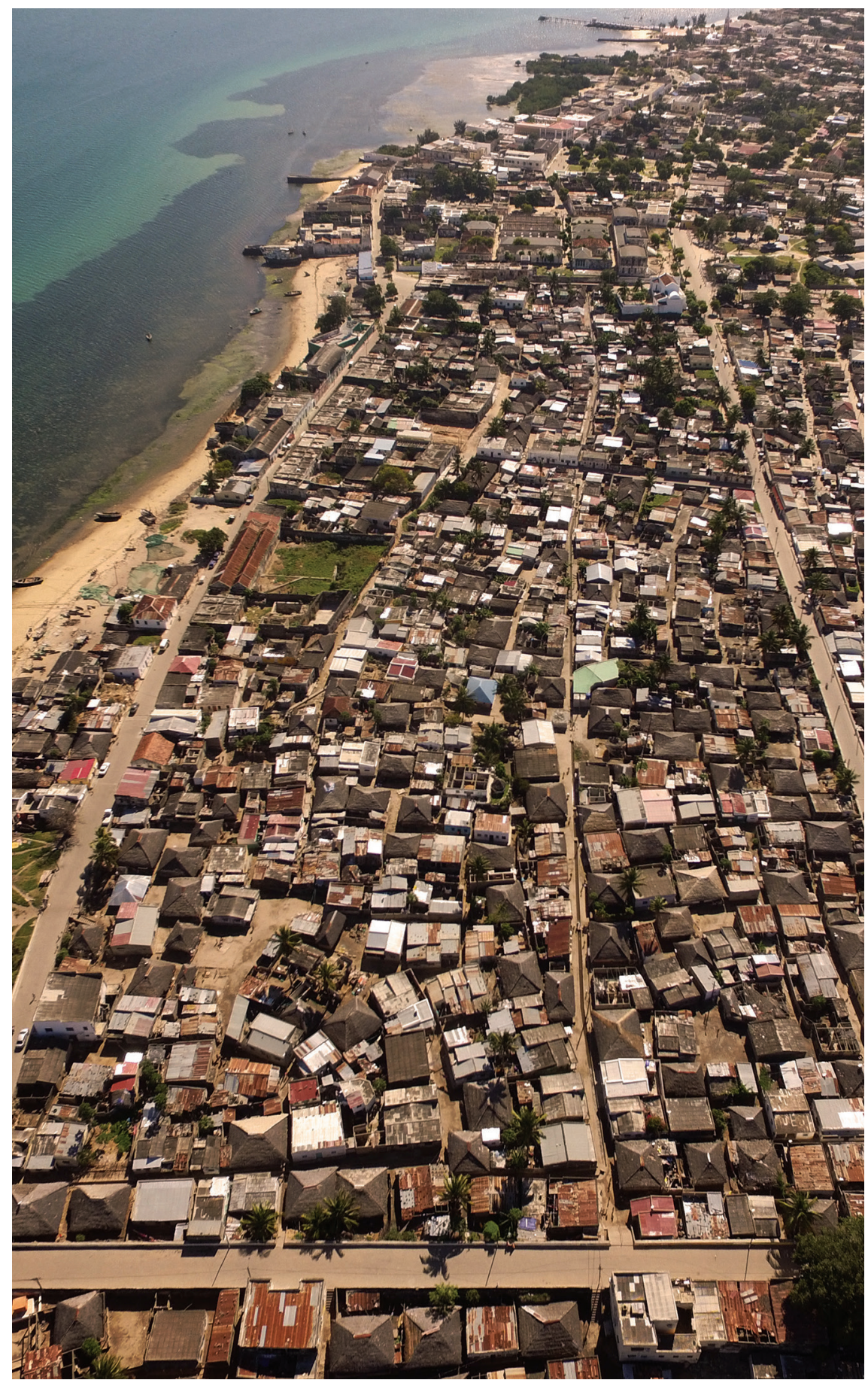




\section{ANÁLISE SWOT}

\section{PONTOS FORTES}

- Inscrição na Lista do Património Mundial

- Riqueza cultural

- Faculdade de Ciências Sociais e Humanas

- Crescimento populacional e população jovem

- Prática de Associativismo nas Comunidades

- Património Material e Imaterial

- Diversidade de Paisagem

- Experiência de gestão de serviços urbanos (recolha lixo)

- Segurança

\section{PONTOS FRACOS}

- Fraca promoção das potencialidades turísticas

- Fraca promoção das atividades

culturais

- Défice de formação em grande parte da população

- Pesca artesanal e informal

- Comércio informal

- Deficiente

distribuição de

equipamentos

- Ausência

de algumas

infraestruturas

- Fraco dinamismo

empresarial

- Fraca conexão

entre a ilha e o

continente

- Baixo

aproveitamento dos

recursos agrícolas

\section{OPORTUNIDADES}

- Capacidade atrativa

- Exploração do

turismo, praia e

mergulho

- Diversificação

das atividades

económicas da

população

- Valorização e

aumento do

alojamento local

associado à

Universidade

- Múltiplos acordos de cooperação

\section{AMEAÇAS}

- Atividades

turísticas em

Nacala porto

e Chocas Mar

(Na Baia de

Mossuril)

- Aumento do custo de vida

da população

da llha

- Tendência de deslocação das atividades económicas

para o

continente

- Fraca

capacidade de investimento

público-privado

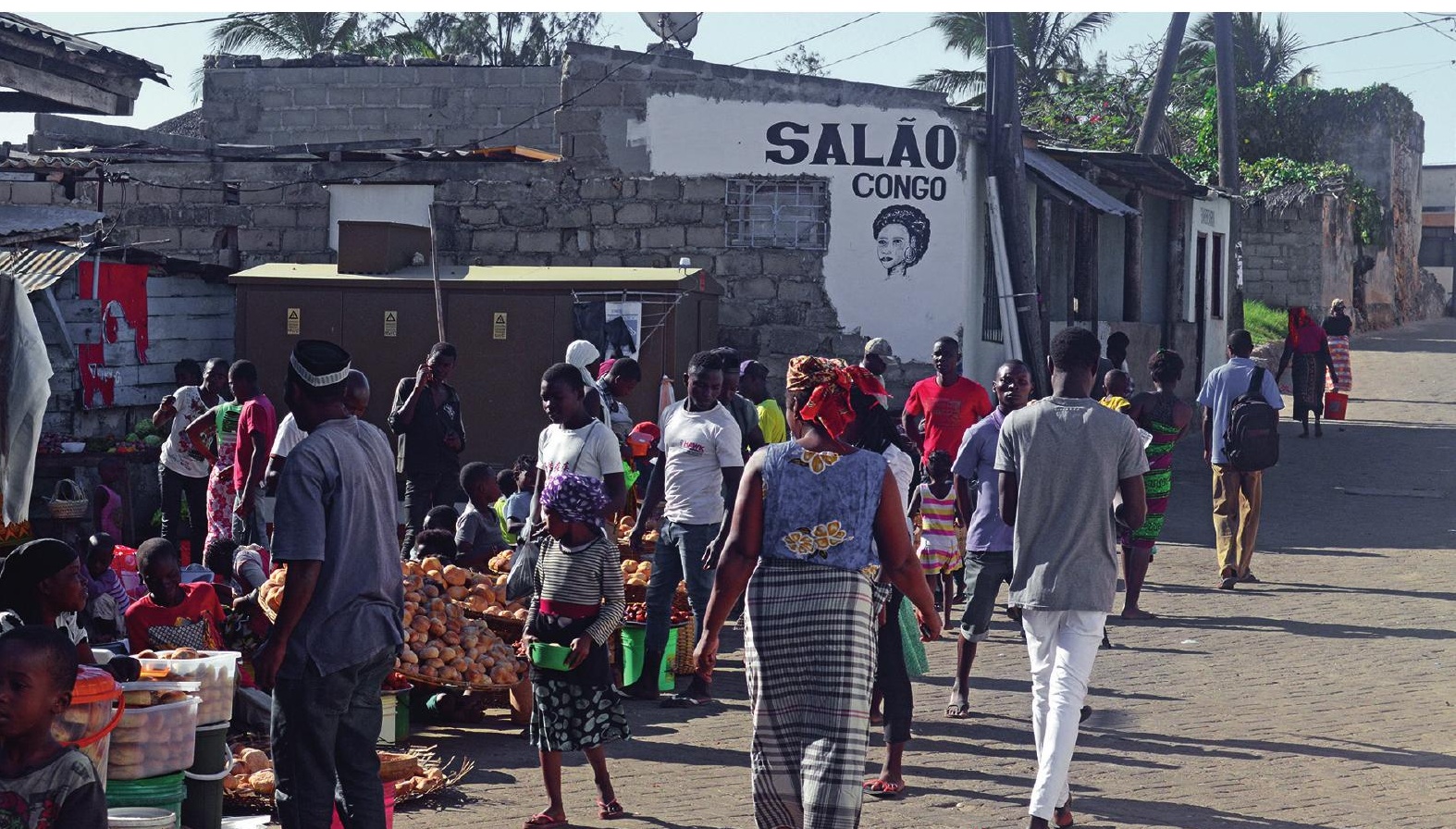




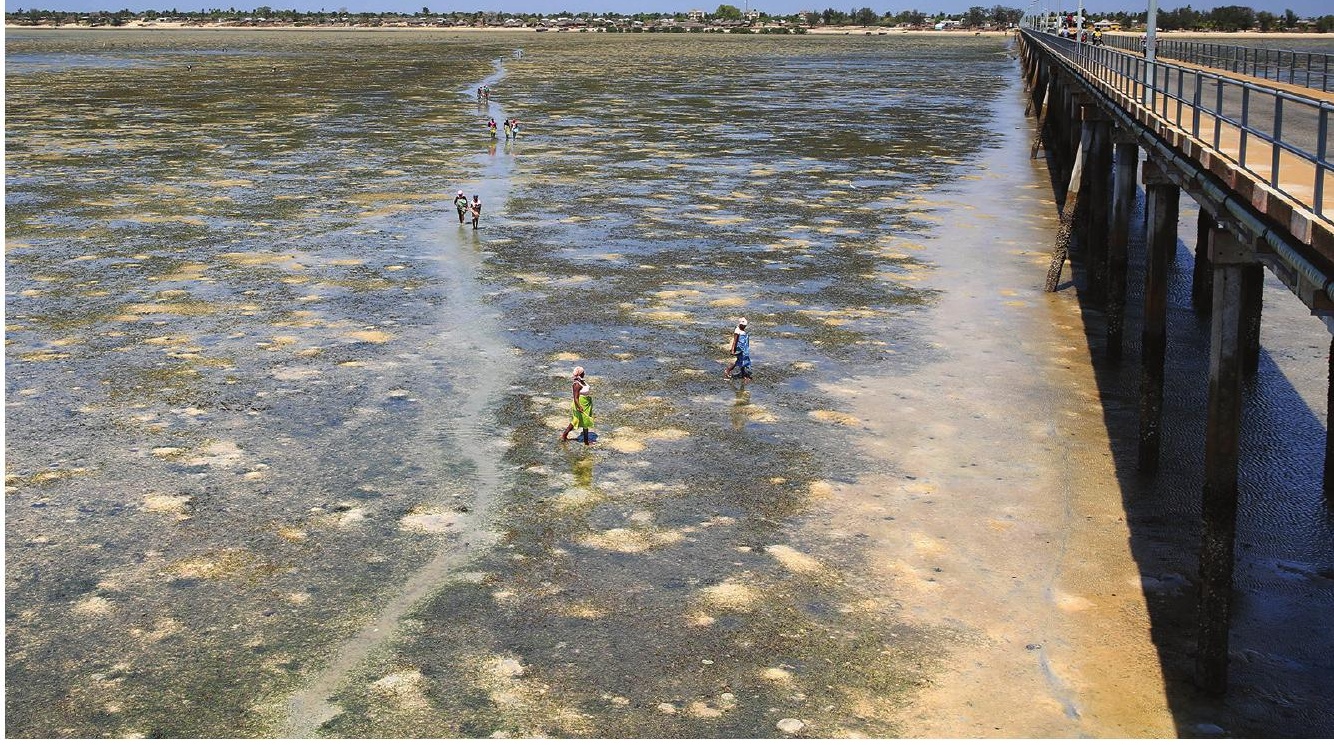

\section{A ILHA. SÍNTESE DA CARACTERIZAÇÃO E DIAGNÓSTICO}

A llha de Moçambique é sede de um distrito municipal, por isso é sede das autoridades governamentais (Assembleia Municipal e Governo da Cidade) e administrativas (Conselho Municipal). Esta estrutura é dividida num modelo de liderança comunitária constituído por 9 cabos e 31 secretários de bairro (8 na parte insular e 22 na zona continental). De acordo com o censo de 2007, a população do distrito era de 48.839 habitantes, dos quais 17.356 na parte insular (Governo do Distrito da Ilha de Moçambique, 2009). A língua mais falada é o emakhuwa e a maioria da população professa a religião islâmica, dividida em oito confrarias religiosas.

Os acessos à llha são feitos maioritariamente por via rodoviária, pela EN 105 que liga a ponte da Ilha à cidade de Nampula e Nacala. A ponte, constituída por uma única faixa de rodagem com várias bolsas de cruzamento, foi construída na década de 1960 e tem uma extensão de cerca de 3,5 Km. Antes da sua construção, as ligações eram feitas apenas por via marítima, a partir de um ancoradouro situado no Lumbo. 
Hoje também é possível chegar à Ilha por via marítima, no entanto, apesar de alguns produtos ainda serem diariamente transportados dessa forma, este sistema de transporte não se encontra organizado e o antigo ancoradouro já não existe.

A rede de abastecimento público de água é assegurada por furos de captação situados na zona continental e é distribuída com uma rede de subsolo na cidade de pedra e cal e com um conjunto de fontanários públicos em toda a ilha. Não existe rede pública de saneamento. Na zona da cidade de pedra e cal, existem sistemas individuais de fossas sépticas, mas na cidade de macuti este sistema é raro, mantendo-se a fossa tradicional e a prática de fecalismo a céu aberto. O escoamento das águas pluviais é uma das maiores fragilidades da Ilha, sobretudo na cidade de macuti, por se encontrar abaixo do nível do mar. Numa tentativa de solucionar este problema, foi criado um sistema de valas de escoamento de águas pluviais e bombas de escoamento em alguns bairros (Esteu, Lithine, Areal e Marangonha). No entanto, essencialmente por razões de manutenção, não é eficaz. Existe distribuição de energia elétrica em toda a ilha, tendo a rede sido recentemente melhorada, apesar de persistirem deficiências.

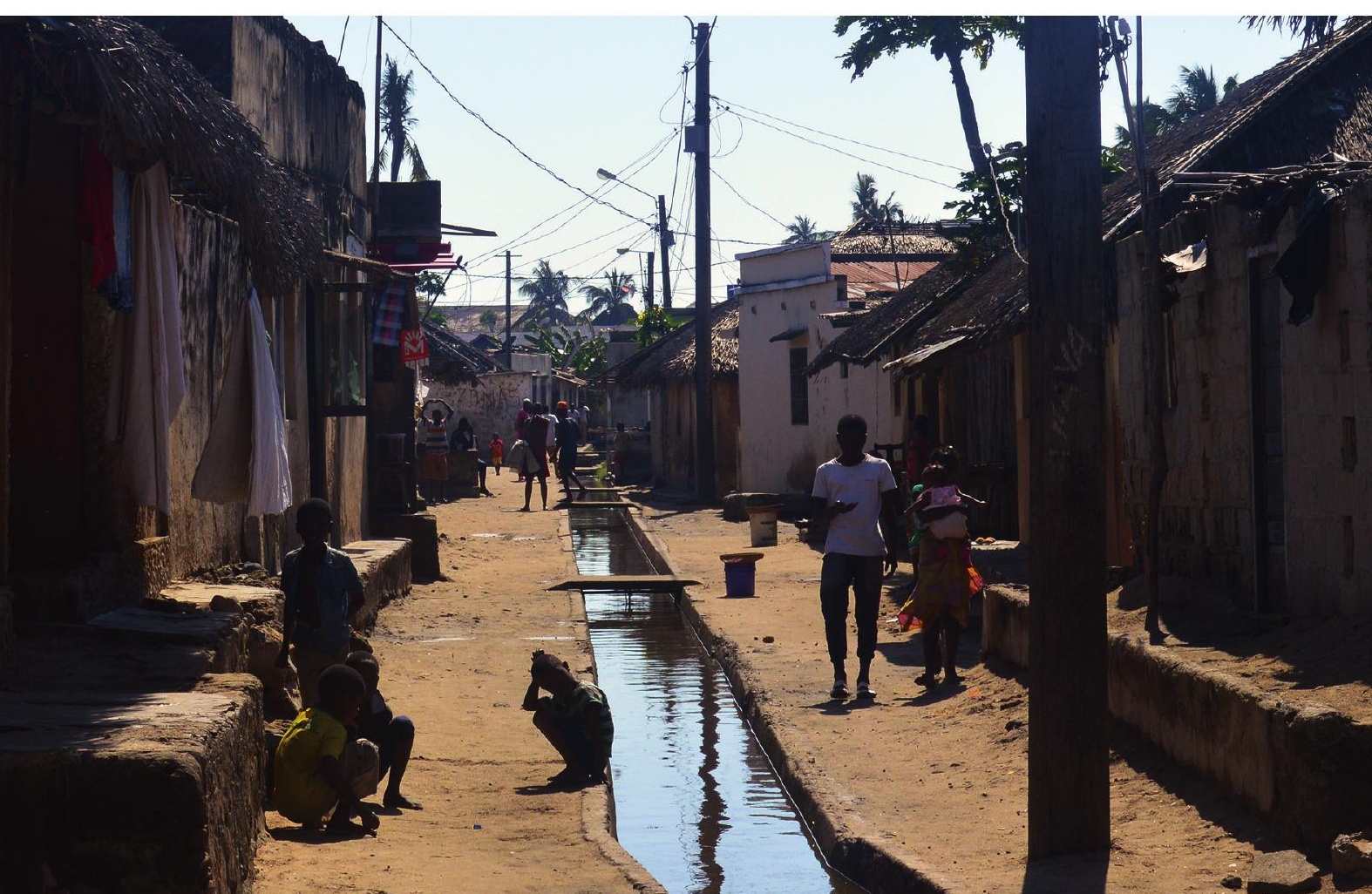


Relativamente a equipamentos de saúde, existe um centro de saúde na parte insular, a funcionar no edifício do antigo hospital, e dois na parte continental, juntamente com um posto de saúde. O distrito conta com dezasseis estabelecimentos de ensino, sete escolas primárias de $1^{\circ} \mathrm{grau}$, sete escolas primárias completas, uma escola secundária geral $\left(1^{\circ}\right.$ e $2^{\circ}$ ciclo), uma escola de ensino técnico profissional e, desde este ano, um polo da UniLúrio.

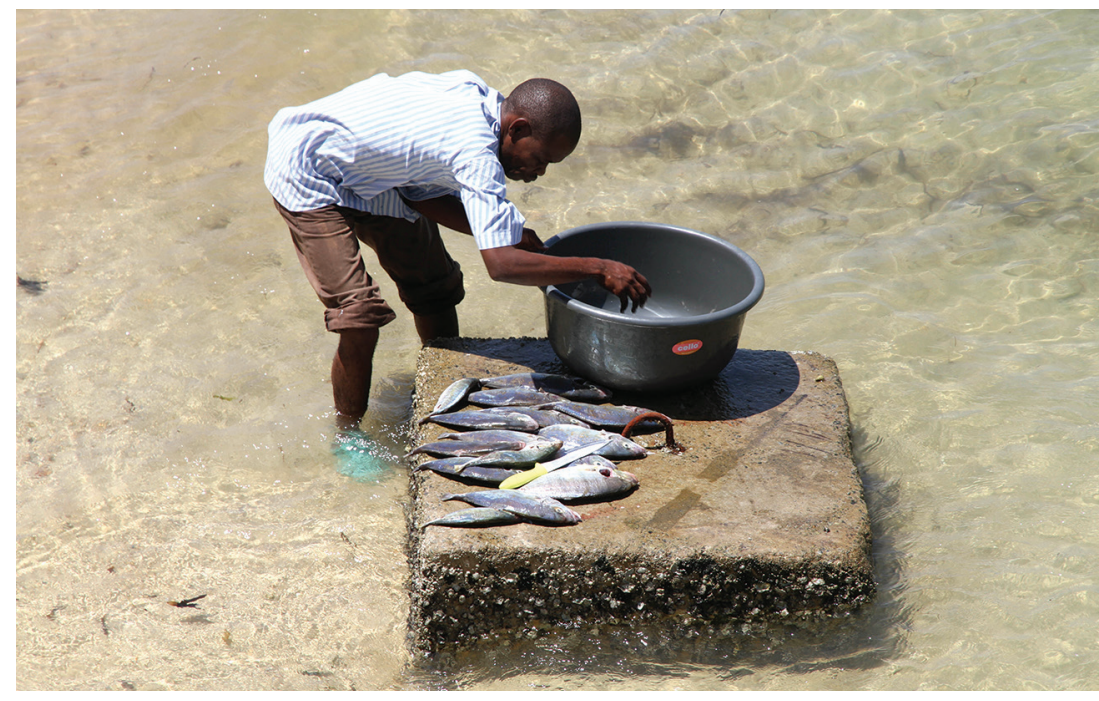

As principais atividades da Ilha estão ligadas ao mar, à pesca e à produção de sal, para além do comércio e de alguma atividade agrícola e pecuária. No entanto, e apesar do número de pessoas dependentes destas atividades, estas funcionam maioritariamente de modo familiar e informal, utilizando técnicas tradicionais. A pesca é desenvolvida pelos homens, com rede de arrasto com barcos à vela ou canoas, enquanto a apanha do marisco é geralmente efetuada por mulheres e crianças durante a maré baixa. Por isto, apesar da riqueza de peixe existente na zona, o volume de exportações é reduzido. De forma semelhante, o sal produzido nas salinas locais é maioritariamente vendido no mercado nacional e sem qualquer tipo de tratamento. Por sua vez, a agricultura existente é de reduzida dimensão e sobretudo de subsistência, incluindo o milho, a mandioca, a mapira, o arroz, a batata-doce, o feijão e as hortícolas (Governo do Distrito da Ilha de Moçambique, 2009: 26). 
A produção pecuária tem oscilado, mas existem algumas criações de gado caprino, ovino e aves, com base numa exploração doméstica. Existem mais de 30 associações e cooperativas na llha relacionadas com os âmbitos económico, social ou cultural. No entanto, a grande maioria destas associações tem um desempenho muito condicionado pelas grandes dificuldades técnicas e económicas locais.

O turismo tem vido a ganhar expressão. Em 2005 a llha tinha uma oferta hoteleira de 89 camas, em quatro anos este número subiu para 300, distribuído por 14 estabelecimentos hoteleiros ou similares (Governo do Distrito da llha de Moçambique, 2009: 25).

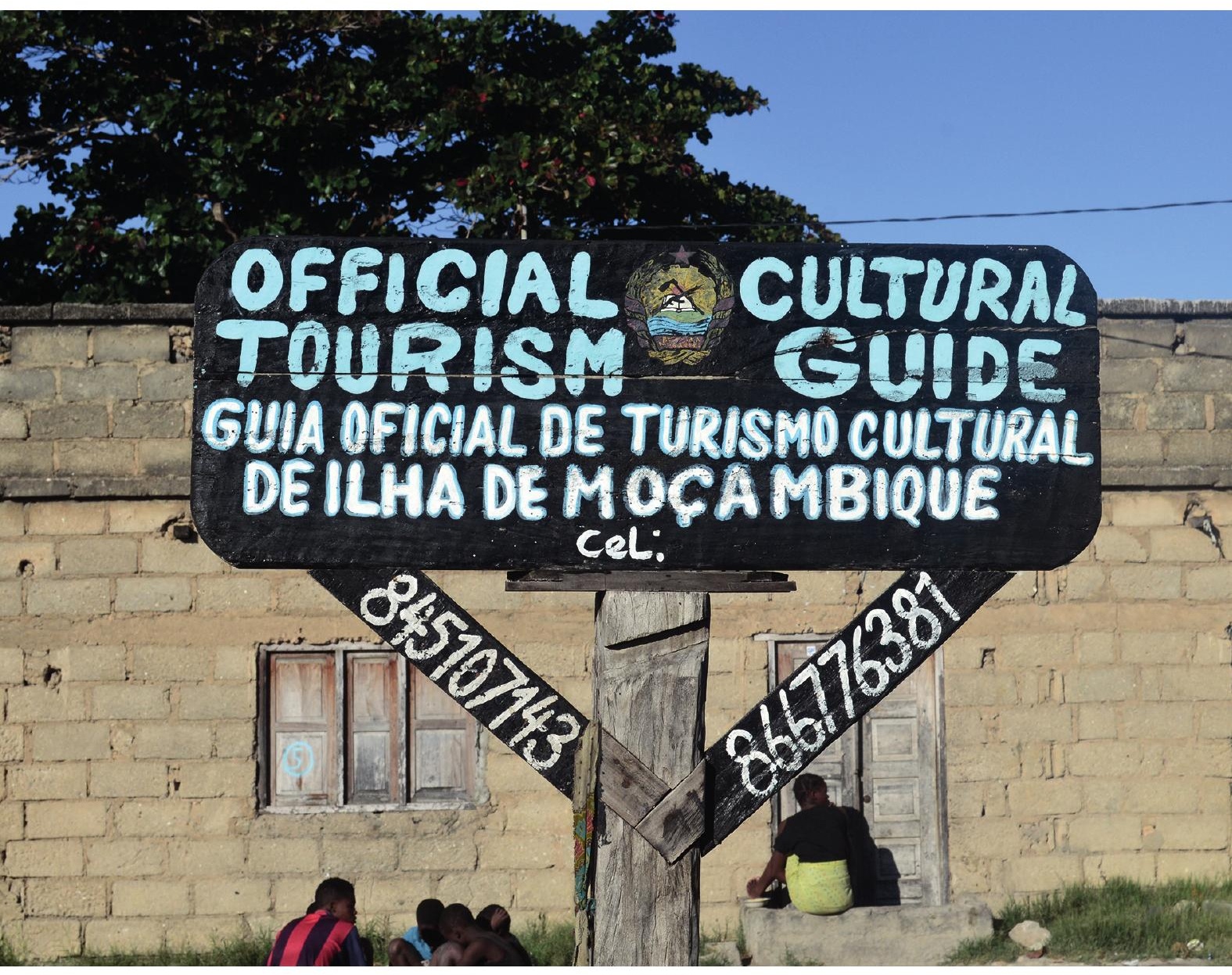




\section{ILHA. QUE FUTURO?}

A estratégia que propomos assenta no reconhecimento da importância do território e do património cultural da Ilha. Se no passado as condições naturais permitiram que se desenvolvesse como entreposto comercial e como primeira capital de Moçambique, hoje este património natural, social e cultural deve ser potenciado para promover o desenvolvimento sustentado da llha e para a afirmar como centralidade com carácter e, assim, como marca. No entanto, carece do reforço das relações com e pelo mar, mas também com o território continental e entre as várias zonas que compõem a llha. Assim, propomos como lema-visão de futuro Ancorar a I/ha, ideia assente na valorização e na promoção da cultura do mar e da cultura local como fator de desenvolvimento e no reforço da coesão territorial, articulando, por um lado, o território insular com o território continental e, por outro, a cidade de pedra e cal com a cidade de macuti. Esta visão divide-se em três grandes objetivos estratégicos:

1) Ilha como Casa, que visa a melhoria das condições de vida das populações. Dentro deste objetivo, propõemse: a) reforçar as ligações entre zona insular e zona continental; b) reforçar ligações entre a cidade de pedra e cal e a cidade de macuti; c) melhorar a qualidade de vida dos habitantes.

2) Ilha como Património, que visa a valorização e a promoção do património cultural. Dentro deste objetivo, propõem-se: a) valorizar e difundir a cultura local; b) desenvolver o turismo.
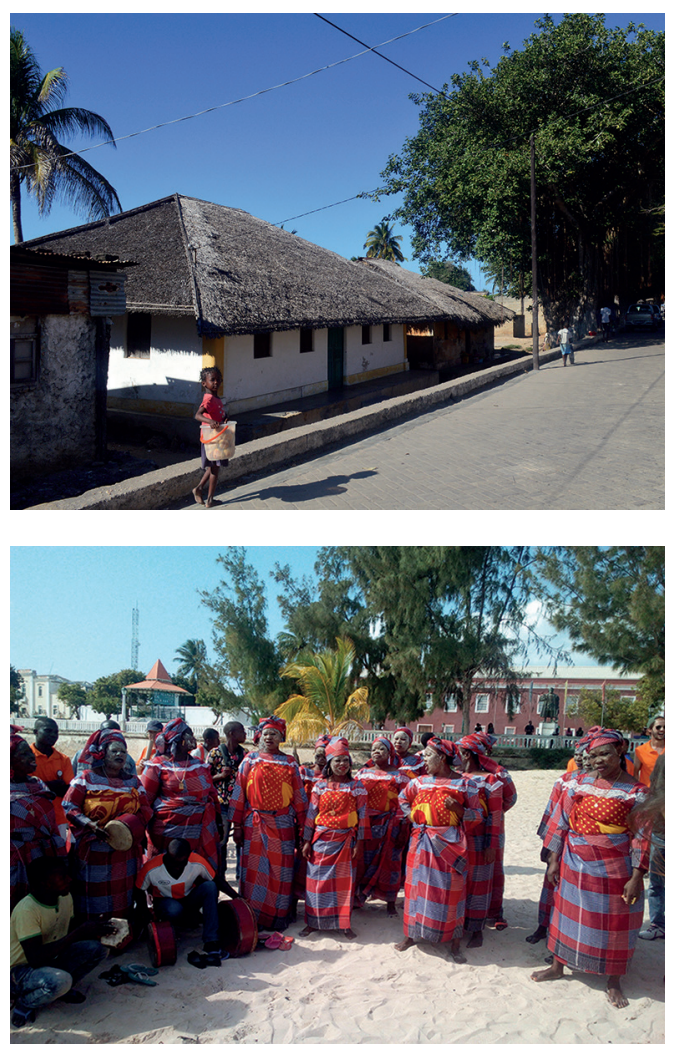
3) Ilha com Futuro, que visa o fomento do desenvolvimento socioeconómico e a valorização e proteção do ecossistema. Para concretizar este objetivo, propõem-se: a) valorizar a paisagem e a relação com o meio ambiente; b) reforçar a capacitação e a participação.

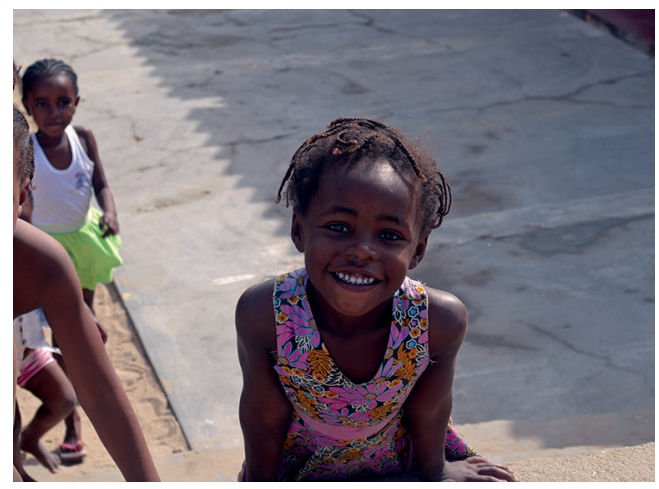

De forma a facilitar a prossecução destes objetivos estratégicos, definimos 15 Projetos Estruturantes que pretendem alavancar o desenvolvimento do território a partir da preservação e do aproveitamento dos seus recursos naturais e culturais:

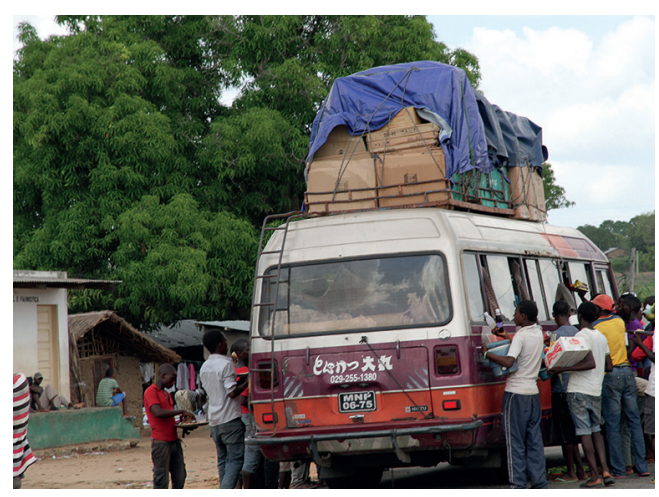

\section{Mais mobilidade}

Pretende-se a criação de um serviço regular de transporte público entre a llha e as principais cidades da Província, assim como a criação de uma ligação direta entre o aeroporto e a llha, considerada essencial para o desenvolvimento do turismo da llha.

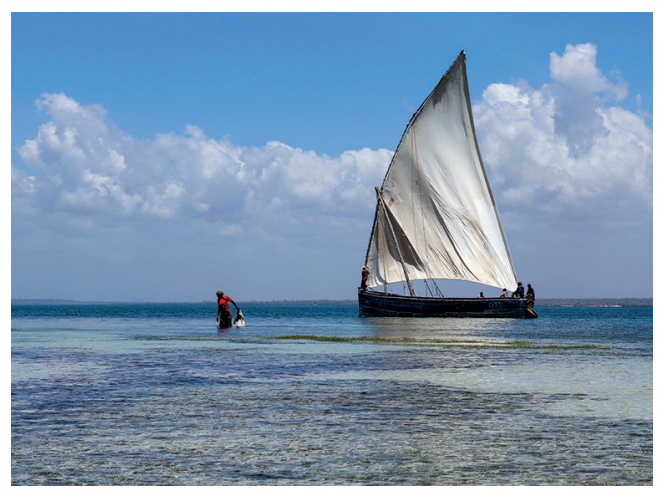

\section{Ligar a llha ao continente}

Propõe-se a criação de um serviço regular de transporte marítimo entre a Ilha e a zona continental, devidamente infraestruturado e sinalizado, localizado no local da antiga ponte cais. Esta medida permite o condicionamento da circulação na ponte, reservada apenas a residentes em datas 
predefinidas, nomeadamente em períodos festivos. Exige, contudo, a criação de um parque devidamente infraestruturado, no bairro de Djambesse, para o estacionamento seguro das viaturas dos visitantes.

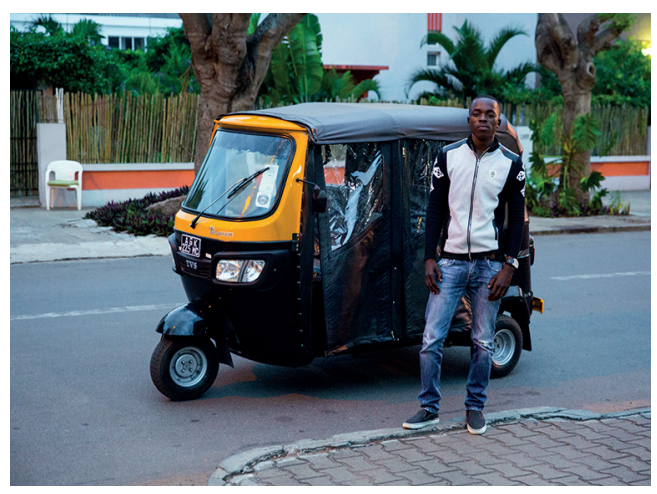

\section{Rede de transportes públicos}

Apesar da reduzida dimensão da Ilha, torna-se essencial dotá-la de uma rede de transportes públicos que facilite as conexões entre a zona sul e a zona norte e que possa ser facilmente utilizada pelo turista. Esta rede deve privilegiar a utilização do táxi bicicleta e do táxi mota. Para este serviço deverão criar-se três praças de táxis distribuídas pela Ilha: na zona sul, junto à ponte; na zona do mercado central; e na zona do pontão, junto ao museu.

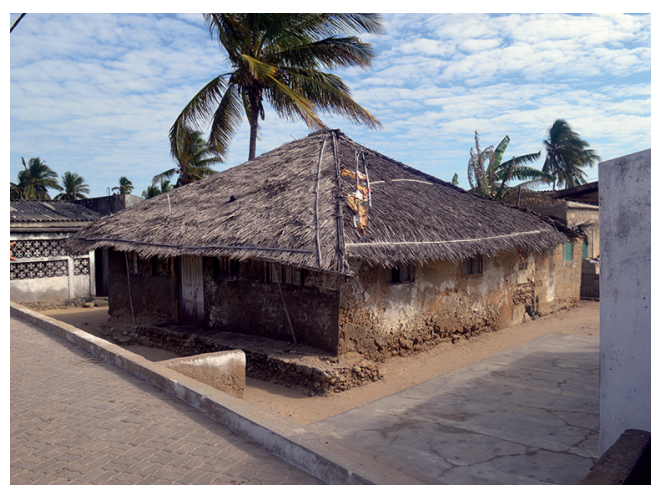

04. Habitar macuti, desenvolver macuti

Esta proposta parte da oportunidade que a instalação da FCSH introduz na Ilha, quer pela necessidade de alojar estudantes nalgumas casas de macuti, quer pela possibilidade de participar no programa "Um estudante uma família". Este programa pretende que os alunos coloquem a sua aprendizagem em prática e ponham os seus conhecimentos ao serviço de uma família. 

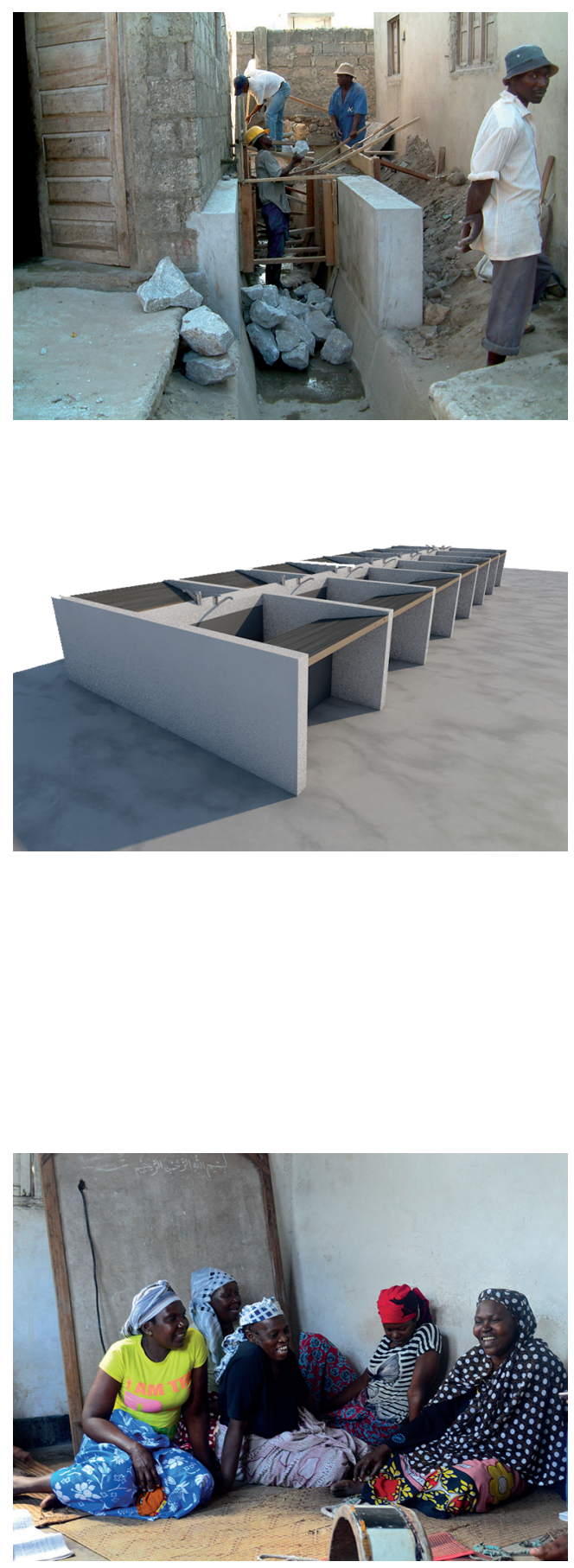

\section{Ilha infraestruturada}

Apesar de algumas melhorias, existem ainda deficiências nas infraestruturas da llha. Como mais urgente, propõe-se a execução da rede de drenagem de águas pluviais nos bairros que ainda não têm esta infraestrutura (Santo António, Macaribe, Sanculo, Murromone e Namalurgo).

\section{Habitar comunitário}

Como forma de melhorar a qualidade de vida da população da cidade de macuti e fomentar o sentido comunitário, propõe-se a criação de alguns serviços comunitários em espaços livres dos bairros. Estes serviços podem ser de vários tipos e carecem de uma definição posterior estudada de acordo com as necessidades da população, apontadas em cada bairro, nomeadamente lavadouros de roupa e estendais, zonas de estar ou desportivas, etc.

\section{Ligar pedra e cal e macuti}

As cidades de pedra e cal e de macuti estão desde sempre dependentes uma da outra. Hoje, a cidade de pedra e cal assume um carácter voltado para o turismo, enquanto a cidade de macuti concentra a maioria dos residentes, bem como a identidade e a cultura locais. 
Neste sentido, pretende-se fomentar a articulação destas zonas através da criação de rotas turísticas que deem a conhecer a cidade de macuti, o seu artesanato, a sua música e a sua dança. Esta medida pretende também incentivar o comércio e a venda destes produtos ao turista.
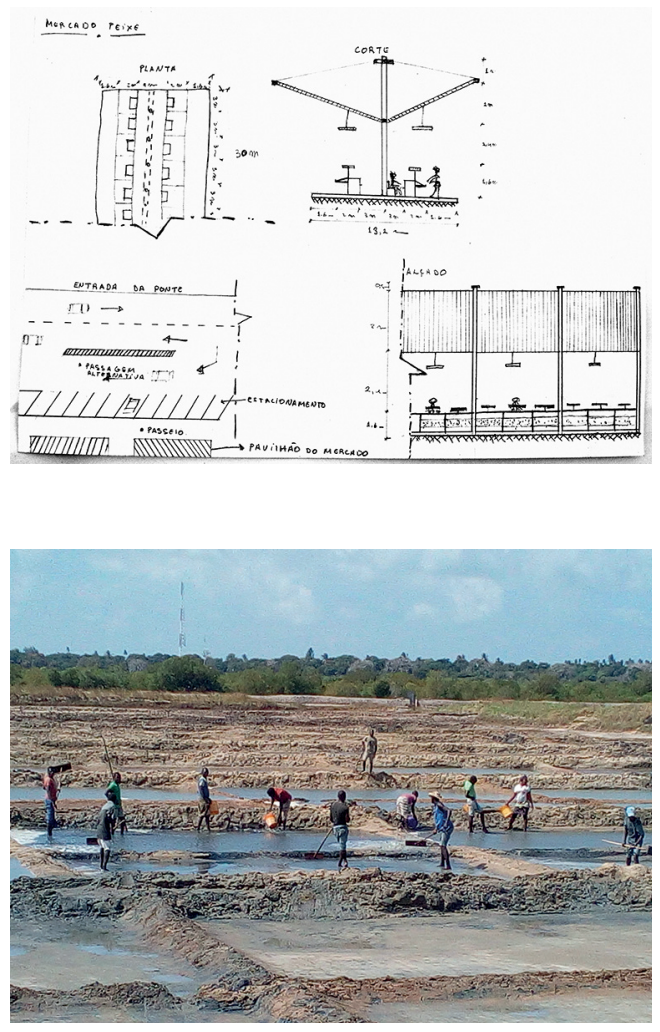

\section{Mercado do peixe}

Atualmente, a maioria do peixe é vendido na zona continental. No entanto, não existe nesta zona um espaço infraestruturado para esta atividade. É desejável a criação de um mercado com as devidas condições higiénicas e sanitárias que permita a refrigeração do pescado e a sua venda.

\section{Ilha empreendedora}

De forma a auxiliar a ação das associações ou cooperativas na Ilha, propõe-se a criação de um gabinete para o apoio técnico, administrativo e jurídico que fomente o seu trabalho, introduza novos modelos organizativos, soluções inovadoras de negócio e permita a divulgação do seu trabalho. Este gabinete deverá assumir um papel de destaque na capacitação dos pequenos empresários da llha e contribuir para a dinamização das pescas, das salinas e do turismo. Deve ainda potenciar a criação de novos produtos associados a estas atividades. 


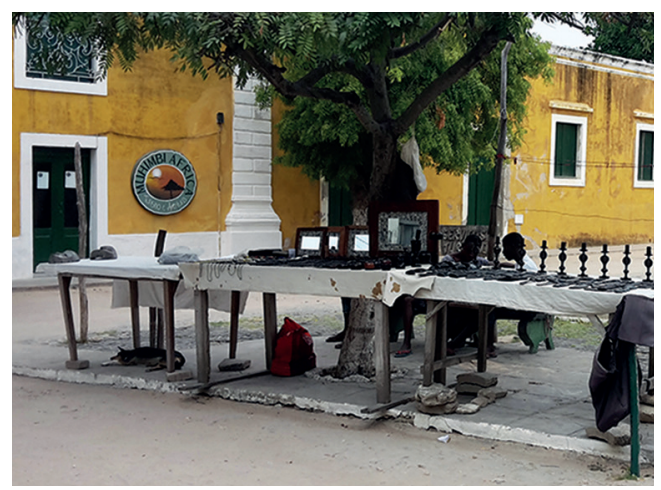

\section{Ilha atrativa}

Apesar da riqueza cultural da llha, consideramos que a sua divulgação não tem sido suficiente. Propõe-se a criação de uma agenda cultural que passe pela realização de uma feira mensal de artesanato e de gastronomia onde os produtos locais e regionais possam ser divulgados. Para a sua implantação propõe-se o espaço do Centro Comunitário na faixa central da Ilha. Consideramos ainda essencial a realização regular de, pelo menos, dois festivais por ano, que reúnam a música, a dança, $\mathrm{o}$ artesanato e a gastronomia. Para a sua localização é proposto o recinto da Fortaleza. Além destas ações, é fundamental a divulgação da llha nos meios turísticos e uma ação cuidada de marketing.

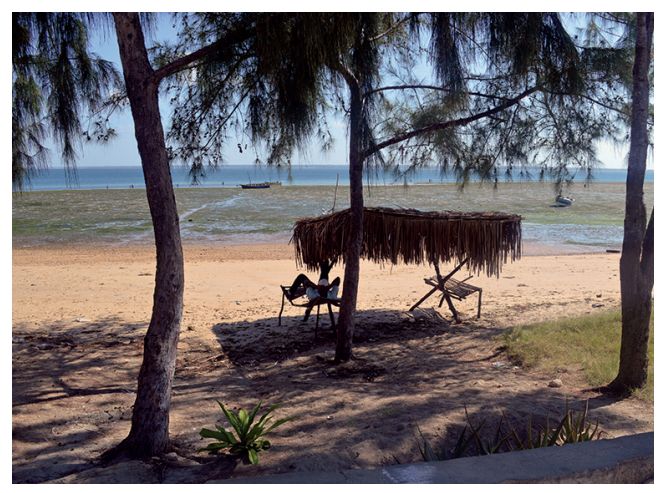

\section{Uma praia melhor}

Afigura-se fundamental a requalificação das praias (e ações de sensibilização à população sobre a importância da sua limpeza e manutenção), para além da requalificação dos sanitários existentes, a construção de novos, bem como de balneários de apoio às praias. Procurando garantir a fiscalização e a manutenção da limpeza das praias, propõe-se a concessão da exploração da vigilância e da limpeza das praias a investidores privados. 


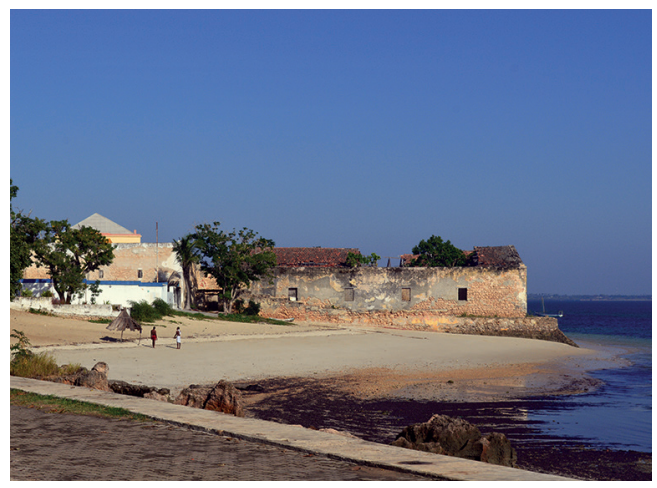

\section{Desportos náuticos}

Apesar da extensão da costa e da recorrente presença de barcos, a Ilha não tem um serviço para o aproveitamento turístico dos desportos náuticos. Consideramos que seria uma mais-valia para o desenvolvimento do turismo a criação de uma escola de vela e de remo. Para este efeito, propõe-se a ocupação de alguns antigos armazéns localizados junto à Praia da Fortaleza (Carramo).

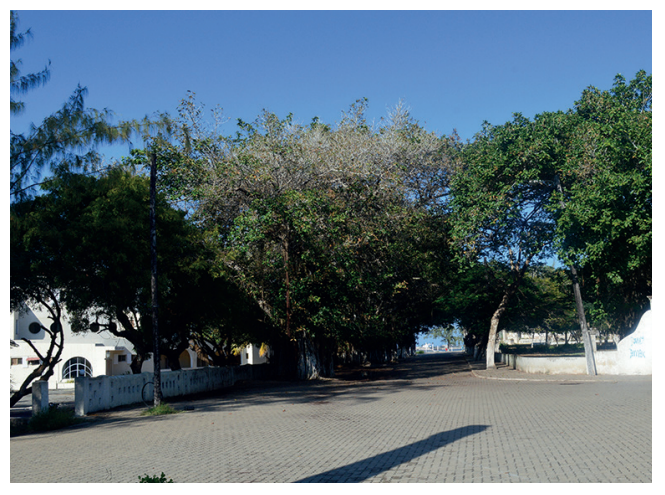

\section{Espaços públicos mais qualificados}

Propõe-se a requalificação dos espaços públicos, em especial ao nível da iluminação pública e da pavimentação de algumas ruas, bem como a requalificação da zona onde decorre a feira semanal, junto à Igreja de Santo António.

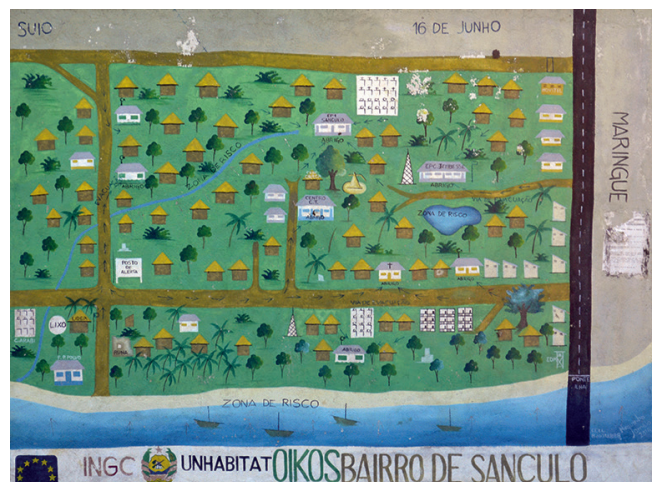

\section{Ilha mais verde}

Face à progressiva redução do número de árvores na Ilha, propõe-se a rearborização das ruas da cidade, bem como a requalificação do Parque Verde junto à fortaleza e a criação de uma nova zona verde no Sanculo. 


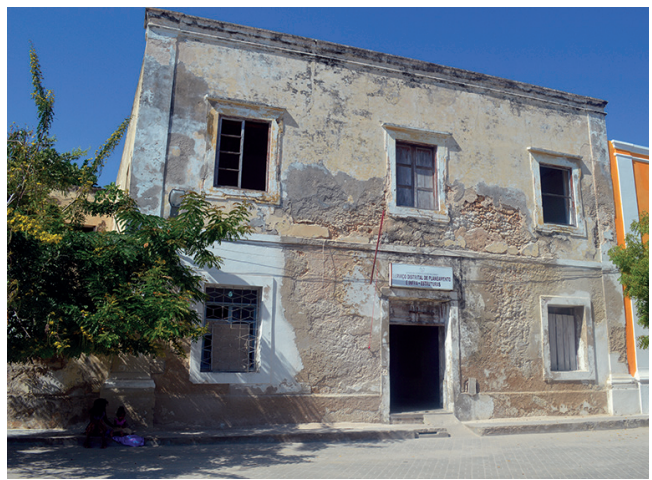

\section{Reabilitação do edificado}

O património edificado da Ilha encontra-se hoje muito degradado e carece de uma ação integrada de reabilitação, obstada pelas dificuldades financeiras ou pela falta de interesse dos proprietários, a que acrescem as debilidades humanas do GACIM que limitam a capacidade de fiscalização das obras de reabilitação e inviabilizam ações de gestão urbana mais extensas. Neste contexto e indo ao encontro das propostas do Cluster da Cooperação Portuguesa, propõe-se o apoio institucional ao GACIM.

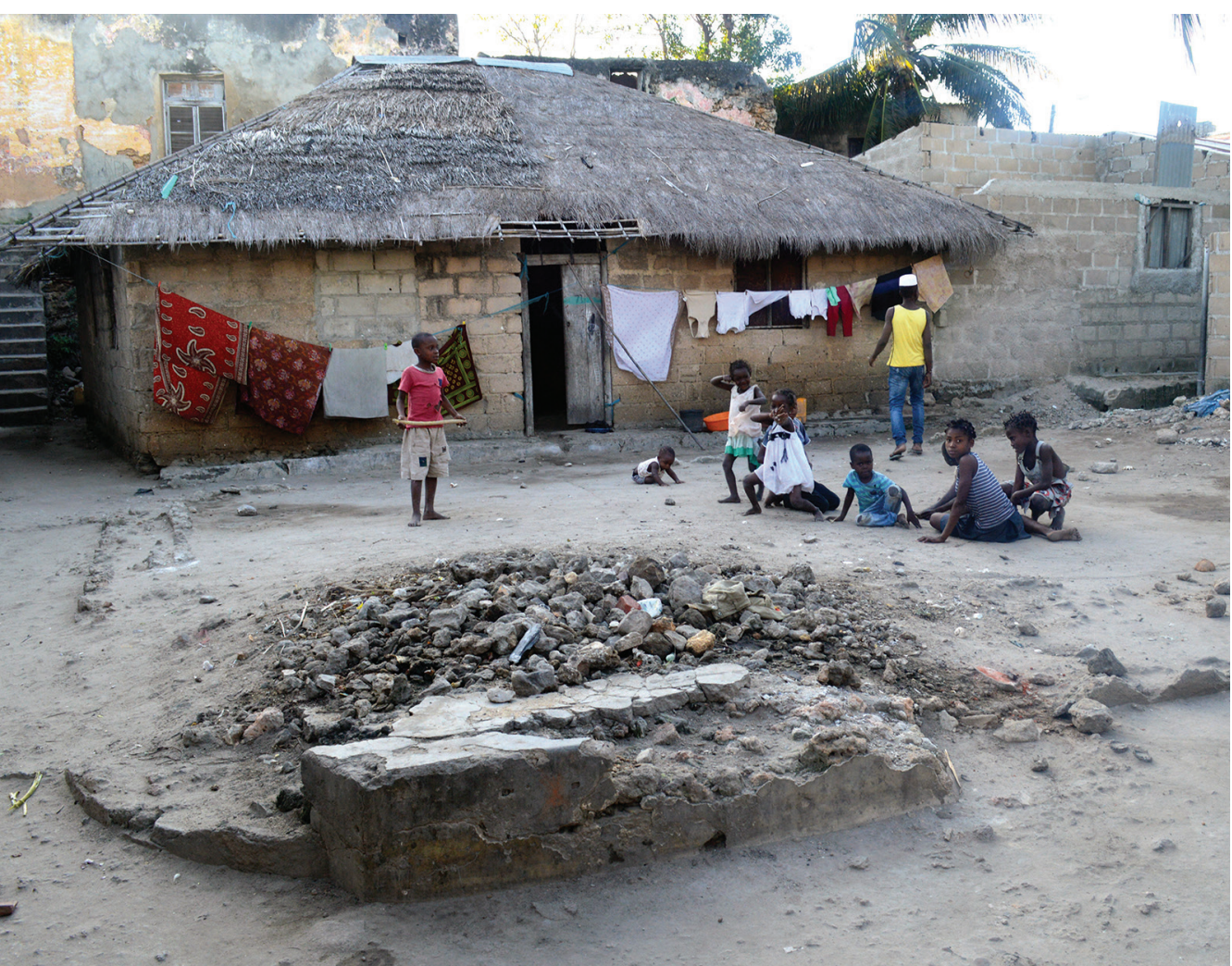




\section{NOTAS CONCLUSIVAS}

Importa ressalvar que os projetos estruturantes e as opções estratégicas esboçadas por esta oficina resultam de um trabalho académico, limitado ao período em que decorreu o Oficinas e não constituem nenhum documento de planeamento. Pretendem apenas apontar algumas medidas e reflexões que poderão ser aproveitadas pelos poderes instituídos e, por essa via, convertidas em documentos legais. Pese embora, importa acentuar a validade e a pertinência dos objetivos definidos: o desenvolvimento da llha a partir da melhoria das condições de vida da sua população, do turismo e do desenvolvimento económico. A inscrição da Ilha na Lista do Património Mundial, em 1991 constituiu uma oportunidade de desenvolvimento que, no entanto, não teve ainda os efeitos desejados. A maioria da população vive em condições de extrema pobreza e não reconhece na inscrição qualquer benefício ou melhoria da sua vida. Muitas vezes sente mesmo o oposto, dadas as limitações impostas aos proprietários. Por outro lado, as entrevistas efetuadas revelaram que grande parte da população de macuti não está sensibilizada, nem reconhece o seu papel na valorização e conservação do seu património cultural. É necessário um trabalho de sensibilização, de envolvimento da comunidade e de reconhecimento do que é a identidade e a cultura locais, provavelmente alargando o que tem vindo a ser divulgado e promovido como património.

A implantação do novo polo da UniLúrio na fortaleza permite a articulação da academia com os poderes locais públicos e privados e pode/deve potenciar o desenvolvimento, não só da economia (pelas necessidades de alojamento, alimentação e abastecimento de bens para estudantes, professores e funcionários), mas também o desenvolvimento de projetos, planos, consultadorias e ações que, de forma integrada, fomentem a utilização responsável dos recursos locais e do património cultural e promovam a melhoria das condições da llha, tanto para os que lá vivem como para todos os que a visitam. 


\section{REFERÊNCIAS BIBLIOGRÁFICAS:}

CARDUCCI, Guido (1998) Ilha de Moçambique. Património Mundial. Um programa de Desenvolvimento Humano Sustentável e Conservação Integral. Volume V- Legislação. Paris: UNESCO-PNUD.

GOVERNO DO DISTRITO DA ILHA DE MOÇAMBIQUE (2009-2012), Plano Estratégico de desenvolvimento distrital (com abordagem DEL incluída em abril de 2012) 2010-2014 (PEDD). Conselho do Distrito. Consultado a 30.06.2017, em: https://issuu.com/artpublications/docs/pedd_ilha_ de_mo__com_del_incluido

INE, Instituto Nacional de Estatística (2015), Estatísticas e Indicadores Sociais, 2013 -2014, Maputo: INE.

INE, Instituto Nacional de Estatística (2012), Estatísticas do Distrito da Ilha de Moçambique. Novembro 2012. Maputo: INE.

UNITED NATIONS (2016), Nova Agenda Urbana. Habitat III. Quito: 17-20 october 2016. Consultado a 30.06.2017, em: http://habitat3.org/wpcontent/uploads/NUA-Portuguese-Angola.pdf

SANDREMAN, Carlos; SILVA, Sandra (2012), "Os clusters como instrumento da cooperação internacional portuguesa para o desenvolvimento, o caso da llha de Moçambique", Working-Paper, WP 104/2012. Consultado a 30.06.2017, em: http://pascal.iseg.utl.pt/ cesa/index.php/ menupublicacoes/working-paper 



\title{
O SISTEMA DE GESTÃO DA ILHA DE MOÇAMBIQUE
}

\author{
Implementação da legislação \\ na área do património edificado
}

Solange Macamo

\section{INTRODUÇÃO: O SISTEMA DE GESTÃO DO PATRIMÓNIO CULTURAL}

O Plano de Gestão e Conservação da Ilha de Moçambique (20102014) (Jopela e Rakotomamonjy, 2014) define, no seu objetivo n. ${ }^{\circ}$ 1, a necessidade da entrada em vigor de um sistema de gestão do sítio de modo a conservar e valorizar o património cultural e natural da llha, salvaguardando o seu estatuto de sítio inscrito na Lista do Património Mundial da UNESCO. A exigência da salvaguarda desse estatuto da llha surge em cumprimento das condições da sua classificação, nomeadamente a integridade e a autenticidade.

De acordo com a UNESCO (2013), a expressão "sistema de gestão" pode ser entendida como uma série de processos que persegue um conjunto de resultados, alguns dos quais com retorno no sistema, e que permite o contínuo melhoramento das suas ações e realizações. Ndoro \& Kiriama (2008) utilizam a expressão "mecanismos de gestão", que podem ser formais ou informais, talvez no mesmo sentido que a designação aqui usada de "sistema de gestão".

Um sistema de gestão do património cultural ajuda a conservar e a gerir um dado imóvel ou conjunto de imóveis de maneira a proteger os valores do património, particularmente o seu Valor Universal Excecional, tratando-se de um bem do Património Mundial e, onde for possível, realça os seus amplos benefícios sociais, económicos e ambientais (UNESCO, 2013, tradução da autora). 


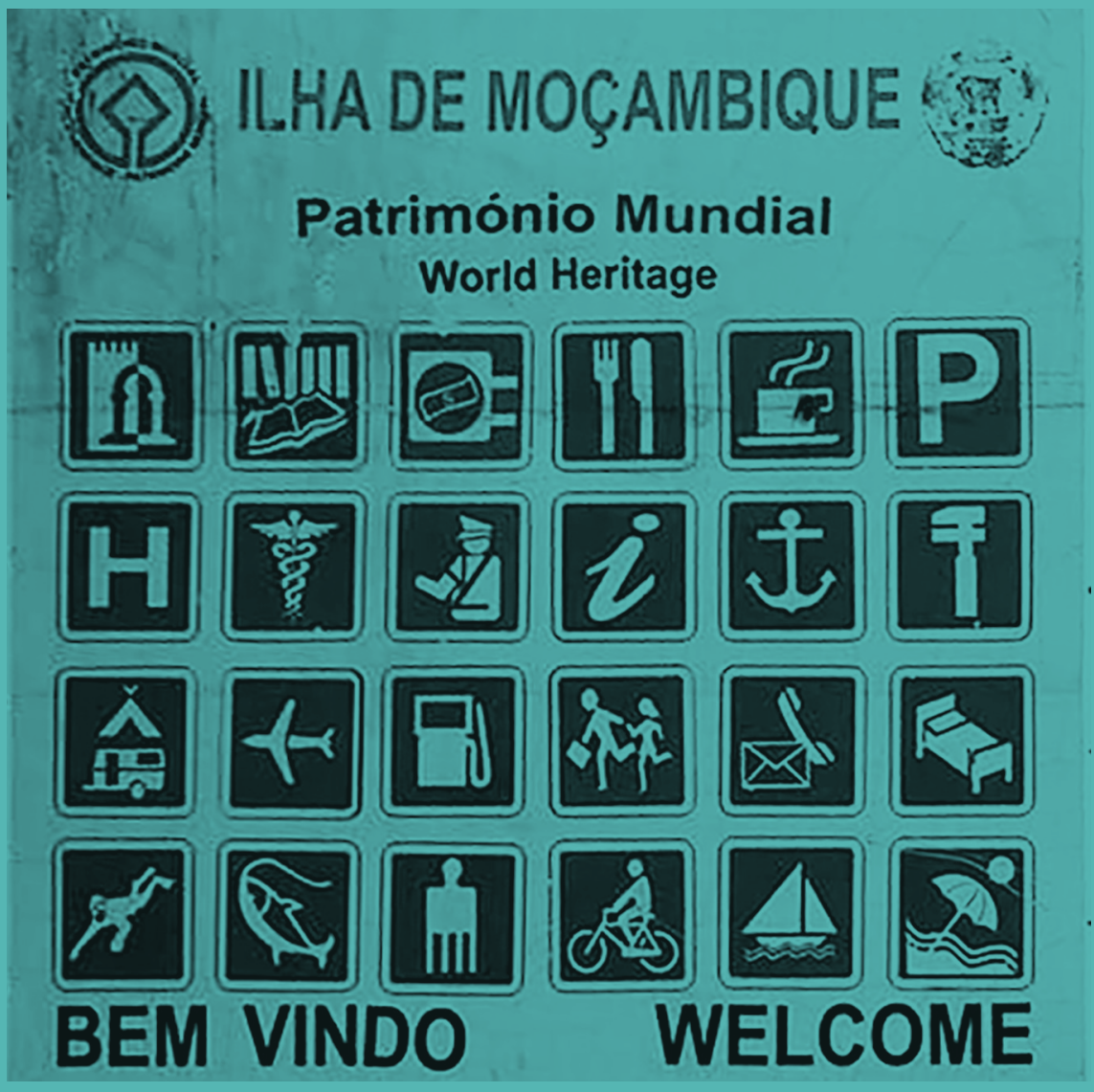

O conceito de valor universal excecional foi consolidado em 1972 pela Convenção sobre a Proteção do Património Mundial, Cultural e Natural da UNESCO. Esta convenção permitiu o entendimento de que determinados bens existentes no mundo são tão importantes que devem ser valorizados por toda a humanidade, cabendo a responsabilidade pela sua gestão a muitas nações, mesmo que a primeira responsabilidade seja de nações individuais (UNESCO, 2013: 29). Por isso, possuem significado cultural e/ou natural a valorizar pelas gerações atuais e futuras de toda a humanidade (Second Cycle of the World Heritage Periodic Reporting for Africa, 2010). Os pressupostos da Convenção foram formulados por um conjunto de países, visando a sua melhor implementação (Machado e Braga, 2010: 13). Alguns deles serão discutidos nas páginas seguintes. 


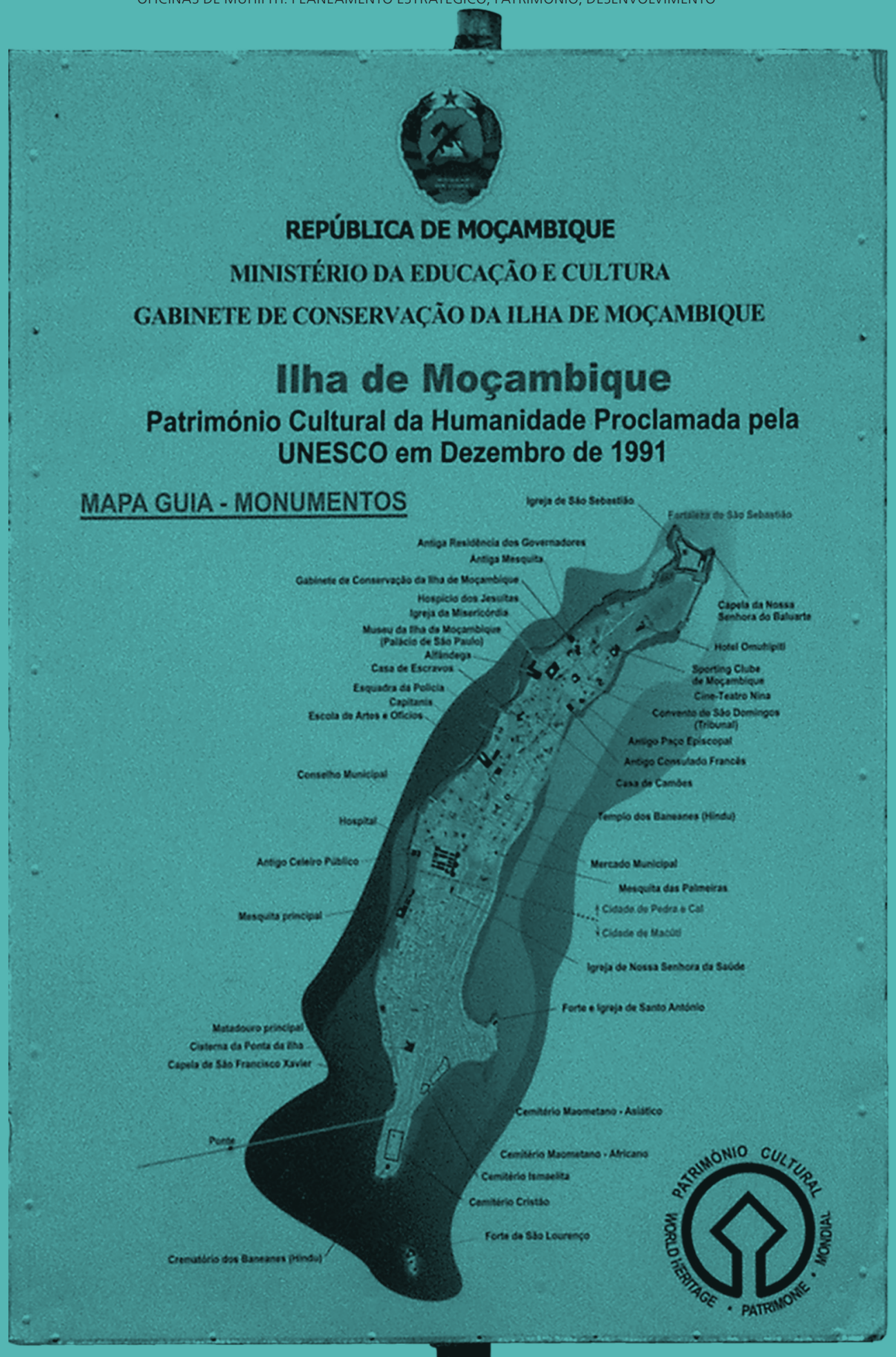




\section{A CONSTRUÇÃO DE UM SISTEMA ARTICULADO DE GESTÃO DO PATRIMÓNIO EDIFICADO}

\subsection{Introdução}

Em Moçambique existem mecanismos formais e informais que permitem a cristalização de um sistema de gestão do património edificado. Fazem parte dos mecanismos formais as instituições do governo, da base ao topo, através das ações programadas - Plano Anual de Atividades e Programa Quinquenal do Governo onde o património edificado é contemplado no contexto do património cultural. No caso dos mecanismos informais, são as comissões de gestão do património cultural que atuam a nível local, sobretudo nas zonas rurais onde, por exemplo, a gestão do património cultural é feita pelos líderes comunitários, por via da custódia tradicional (Jopela, 2006). O Governo de Moçambique tem uma política de monumentos que define prioridades para a conservação e gestão de monumentos, conjuntos e sítios (Resolução 12/2010, de 2 de junho). Esta política destaca a valorização dos monumentos para a educação e o turismo cultural, em benefício da sociedade, como formas de um sistema de gestão do património cultural. O Plano de Gestão da Ilha de Moçambique é implementado pelo Gabinete de Conservação da Ilha [GACIM]. O seu estatuto orgânico contempla uma comissão técnica, como órgão de aconselhamento, que agrega as instituições locais do governo, um representante da sociedade civil da Iha, assim como da UNESCO (Decreto n. ${ }^{\circ}$ 28/2006, de 13 de julho).

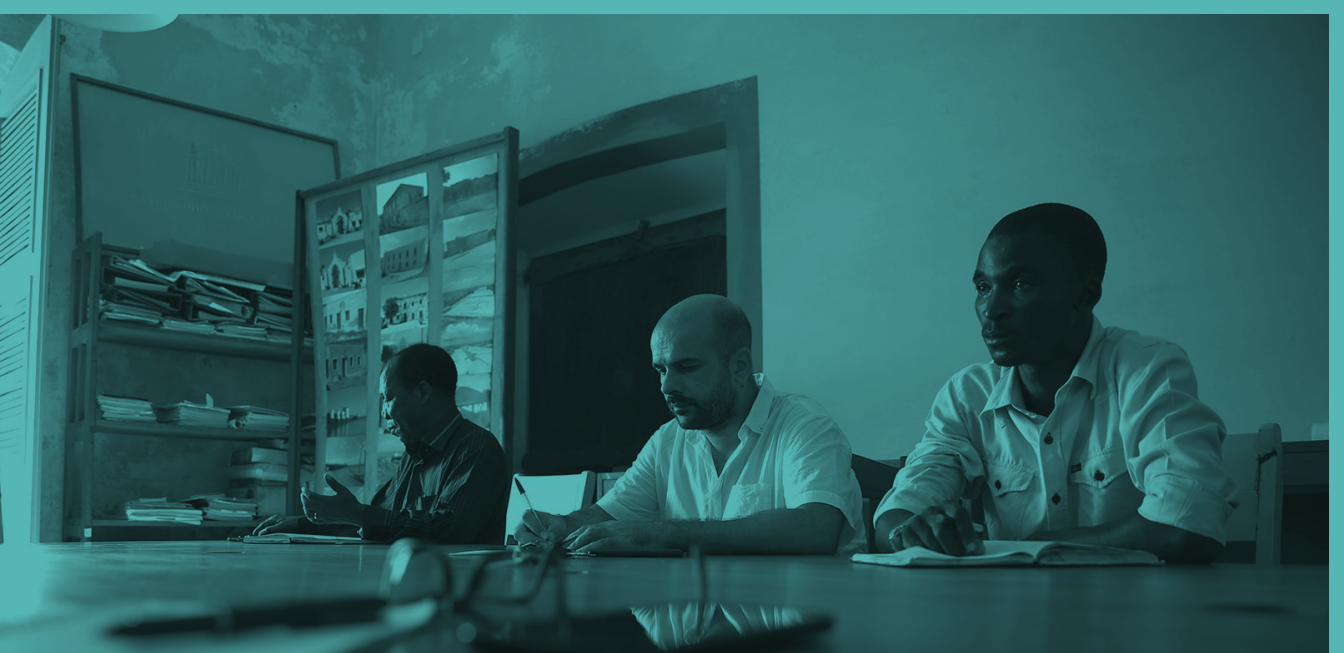


Nesta rubrica começarei por descrever os órgãos de gestão dos bens culturais imóveis a nível nacional, para, de seguida, apresentar o sistema articulado de gestão do património edificado, em particular para a llha, recorrendo à legislação.

\section{2. Órgãos de gestão}

O Regulamento sobre a Gestão dos Bens Culturais Imóveis (Decreto n. ${ }^{\circ}$ 55/2016, de 28 de novembro) prevê três níveis de gestão dos bens culturais imóveis:

i) a entidade superintendente da área da Cultura;

ii) o Conselho Nacional do Património Cultural;

iii) Comissões de Gestão. Os museus e os centros de interpretação podem, em determinadas circunstâncias, serem envolvidos pelo setor que superintende a área da cultura na gestão dos bens culturais imóveis, quando o seu perfil estiver relacionado com estes.

A entidade superintendente da área da cultura é o órgão do Estado responsável pela direção e coordenação da Política de Monumentos, a nível nacional, no que à gestão dos bens culturais imóveis diz respeito. Contudo, compete ao Conselho Nacional do Património Cultural, como órgão de consulta, emitir recomendações aos órgãos competentes sobre a proteção, financiamento e utilização dos bens culturais imóveis, entre outros. As comissões de gestão funcionam a nível local, sendo criadas pelas administrações de distrito e dos conselhos municipais, como depositários do património cultural (Lei 10/88, de 22 de dezembro), em coordenação com a entidade superintendente da área da cultura. As comissões de gestão, por atuarem a nível local, possuem maior relevância nesta comunicação, sendo a sua atividade aplicável ao caso da Ilha. Uma das suas responsabilidades é garantir que as comunidades locais, como depositárias legitimadas pelo direito costumeiro, sejam preferencialmente beneficiárias do uso do património cultural, no âmbito dos programas de educação e de turismo cultural (Decreto n. $55 / 2016$, de 28 de novembro). 


\subsection{Articulação do sistema de gestão do património edificado}

A articulação do sistema de gestão do património edificado está prevista no Decreto n. ${ }^{\circ}$ 55/2016, de 28 de novembro (com destaque para os arts. 39 e 42 sobre a gestão pública e privada de bens culturais imóveis, e sobre o uso compatível e sustentável de bens culturais imóveis, respetivamente).

Para o tema em questão, são relevantes os usos compatíveis aplicáveis para o património edificado da llha, entre outros, a educação, as atividades de pesquisa científica, o turismo, as atividades sociais (idem: art. 42).

Como acontece com outros bens do património cultural do país, a articulação do sistema de gestão do património edificado da llha é feita de acordo com a hierarquia estabelecida para o funcionamento dos ministérios, desde o nível central, provincial e distrital, com as devidas particularidades. Na llha funcionam dois principais órgãos de governo que são responsáveis pela gestão do património edificado: o Conselho Municipal, dependente do Ministério da Administração Estatal e Função Pública; e o GACIM, instituição do Ministério da Cultura e Turismo. As competências do GACIM estão detalhadas nos seus dois estatutos, específico (Decreto n. ${ }^{\circ}$ 27/ 2006) e orgânico (Decreto n. ${ }^{\circ}$ 28/2006) de 13 de agosto, como instituição responsável pela materialização das políticas do governo na área de conservação e gestão do património cultural e natural da Ilha. O diretor do GACIM, Celestino Girimula, em comunicação pessoal, enfatizou a necessidade de uma maior operacionalização destes instrumentos, designadamente através da clarificação de competências do GACIM na sua relação diária com os depositários e organismos de decisão a vários níveis, local e nacional. Neste contexto, o Regulamento sobre a Classificação e Gestão do Património Edificado e Paisagístico da Ilha de Moçambique (Decreto n. ${ }^{5}$ 5/2016, de 28 de novembro) específica, no seu artigo 4, que a proposta do uso do património edificado da ilha compete ao Município, em coordenação com o GACIM e com as partes interessadas. Contudo, a decisão sobre o seu uso compete ao setor que superintende a área da cultura, ouvido o Conselho Nacional do Património Cultural. Os artigos $41,42,43,48,51,52$ e 54 definem os procedimentos relacionados com a notificação, embargo ou demolição de obras, fiscalização, pagamento e atualização das multas, destino do valor das multas, a serem implementados de forma articulada. 


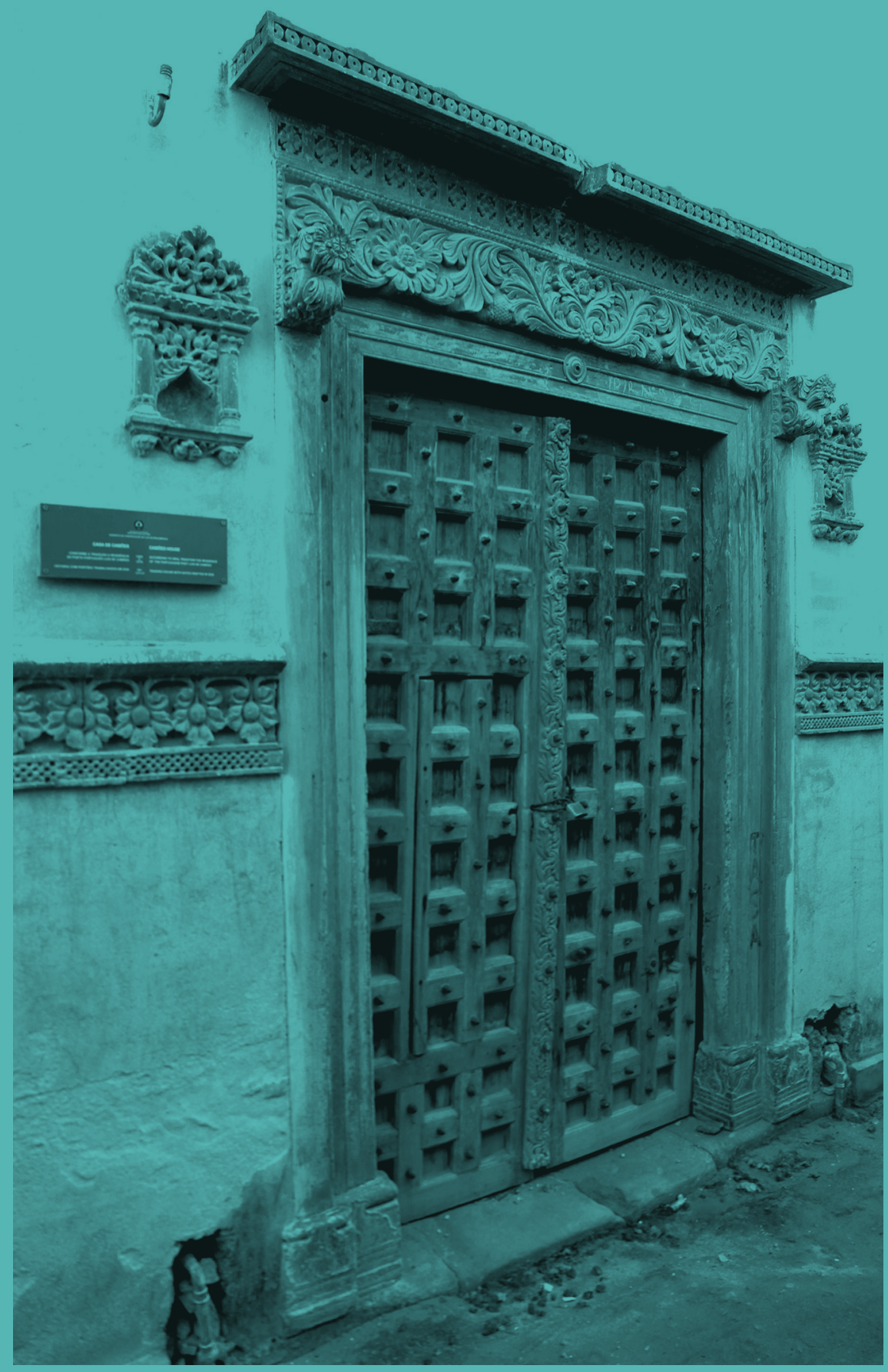




\section{A PRESERVAÇÃO DO VALOR UNIVERSAL EXCECIONAL DA ILHA DE MOÇAMBIQUE E AS CLASSES DO PATRIMÓNIO EDIFICADO}

\subsection{Introdução}

A área da llha de Moçambique classificada, inscrita na Lista do Património Mundial da UNESCO de acordo com os critérios iv) e vi), tem cerca de $1 \mathrm{~km}^{2}$ (fig. 1), perspetivando-se o alargamento da zona de proteção para o continente e a integração do Património Arqueológico Subaquático. Foi com base nesses critérios que foi também definido o valor universal excecional da llha de Moçambique, traduzido pela homogeneidade do seu tecido urbano, desde o século XVI até hoje.

O acompanhamento da UNESCO sobre a manutenção das condições da classificação do Património Mundial, como acontece com a llha, é feito através de relatórios periódicos e da monitorização reativa (Machado e Braga 2010: 18; Macamo 2014: 20). Cabe, por isso, aos gestores da Ilha acima referidos, prestar contas do trabalho realizado ao Centro do Património Mundial da UNESCO, pois esse é um dos deveres do Estado Moçambicano para que continue a manter as condições da sua inscrição, evitando, por conseguinte, ser integrada na Lista dos Bens em Perigo. Ao analisar as condições de integridade e autenticidade, importa fazer referência ao paradigma da conservação urbana que foi recentemente atualizado no âmbito da Recomendação sobre a Paisagem Urbana Histórica (UNESCO, 2011). Esta revisão permite introduzir uma nova visão de cidades históricas vivas contra a noção estática monumentalista do passado (Van Oers, 2013). Basicamente, esta nova visão está virada para a gestão do património em benefício das comunidades locais atuais e do futuro e inclui: (i) a necessidade constante de adaptação e modernização em reconhecimento dos ciclos de vida das cidades; (ii) o envolvimento comunitário e dos decisores na gestão do património, o que implica negociação e resolução de conflitos; (iii) a mudança da noção de património, que necessita do alargamento da sua abordagem (idem, 2013: 10). Esta visão tem relação com o conceito de proteção e transformação descrito por Ana Pereira Roders (2013) que, na prática, reconhece que a mudança pode ocorrer no tecido do património edificado, desde o período da inscrição na 


\subsection{As Classes do Património Edificado}

A definição das Classes do Património Edificado foi feita com a ajuda da Faculdade de Arquitetura e Planeamento Físico da Universidade Eduardo Mondlane [FAPF-UEM], cuja liderança coube ao seu anterior diretor, professor Luís Lage, com o apoio do professor Júlio Carrilho. O trabalho comportou a elaboração de dois regulamentos, entre 2014 e 2016: um geral e outro específico para a llha, sob a supervisão do jurista Carlos Serra, em colaboração com a Direção Nacional do Património Cultural e com o GACIM, ambos do Ministério superintende da área da cultura. Houve também trabalho de campo na llha, do qual resultou a elaboração do catálogo dos edifícios classificados da Ilha (Decreto n. ${ }^{\circ}$ 54/2016, de 28 de novembro). A fase final da elaboração dos regulamentos, em 2016, contou com a supervisão do Gabinete Jurídico do Ministério da Cultura e Turismo.

A tabela que se segue resume as Classes do Património Edificado e os correspondentes níveis de intervenção permitidos de acordo com a Política de Monumentos (Resolução n. ${ }^{\circ}$ 12/2010). À Fortaleza de São Sebastião (fig. 2) foi atribuída a Classe $A+$, onde são permitidas a conservação e o restauro que visa garantir a preservação do seu significado cultural.

\begin{tabular}{|c|c|c|}
\hline Classes & Definição & Nível de intervenção \\
\hline A+ & $\begin{array}{c}\text { Com Valor Universal } \\
\text { Excecional }\end{array}$ & Conservação e Restauro \\
\hline A & Com Valor Elevado & Conservação e Restauro \\
\hline B & Com Valor Médio & Reabilitação \\
\hline C & Com Valor Limitado & Reconstrução \\
\hline D & Com limitado valor individual & Reconstrução \\
\hline
\end{tabular}

Tabela demonstrativa das Classes do Património Edificado e níveis de intervenção (tabela simplificada no âmbito da apresentação do Decreto ao Conselho de Ministros em 2016)

O modelo de atribuição de classes do património edificado pode ser facilmente usado e evita os riscos de subjetividade no ato da emissão de pareceres sobre as intervenções a serem efetuadas. Contudo, a implementação destas classes deve ser rigorosamente complementada pela observância das recomendações da UNESCO (2008), conforme 
previsto no Decreto 54/2016, de 28 de novembro, nomeadamente a necessidade de este órgão ser consultado pelo Estado Membro da Convenção antes de qualquer intervenção.

\section{CONCLUSÃO}

Não obstante o tema apresentado ser específico para o património edificado, foram levadas em conta outras designações de contextualização genérica e legal de património cultural, ou de bens culturais imóveis.

A reflexão sobre o sistema de gestão do património edificado da llha foi alvo de vários debates, particularmente a nível de um seminário temático promovido pelo Ministério da Cultura e Turismo, em 2015, em colaboração com a FAPF-UEM e com o apoio da Embaixada de Espanha. Participaram no seminário vários técnicos do património cultural vindos de quase todo o país, assim como os estudantes do Curso de Arqueologia e Gestão do Património Cultural da Faculdade de Letras e Ciências Sociais da UEM. A colaboração das universidades na gestão do património cultural, particularmente o edificado, é importante porque ajuda a resolver o problema da carência de quadros qualificados nesta área.

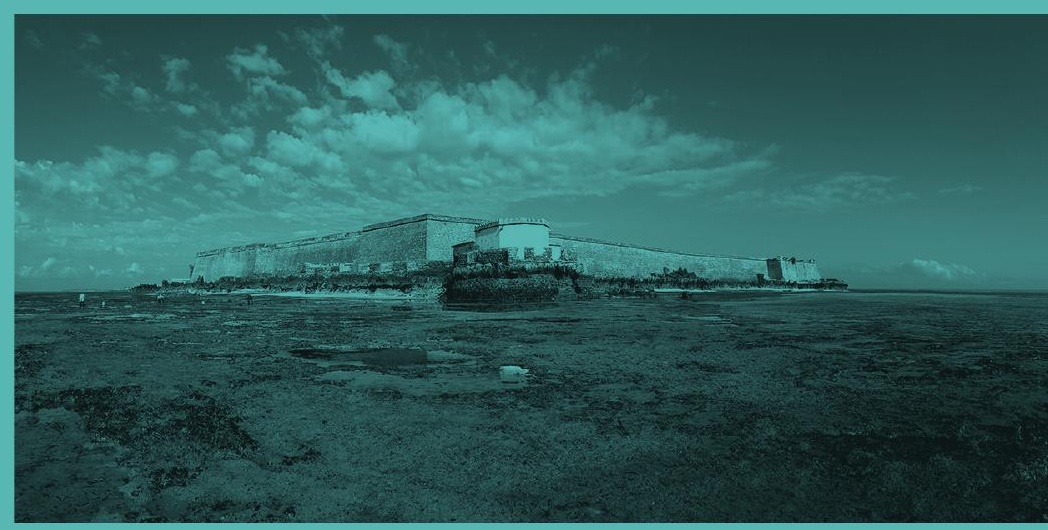

A Fortaleza de São Sebastião é um dos poucos monumentos da llha que beneficiou de uma intervenção substancial, embora numa fase inicial de estabilização da sua estrutura, por iniciativa do Governo de Moçambique, com o apoio do Governo do Japão, da União das Cidades Capitais de Língua Portuguesa [UCCLA], do Instituto 
Português de Apoio ao Desenvolvimento [IPAD], do Governo da Flandres e do Governo da Holanda (Eloundou \& Weydt, 2009). A fortaleza da Ilha, por também ser o maior monumento nacional, tem despertado o interesse de várias instituições, nomeadamente para fins socioculturais, didático-científicos e turísticos. O sistema de gestão aqui discutido possibilita a tomada de decisão de forma célere sobre o método de intervenção neste conjunto, com base nas classes do património, assim como sobre qual a instituição de gestão e os usos compatíveis, salvaguardando o seu valor universal excecional.

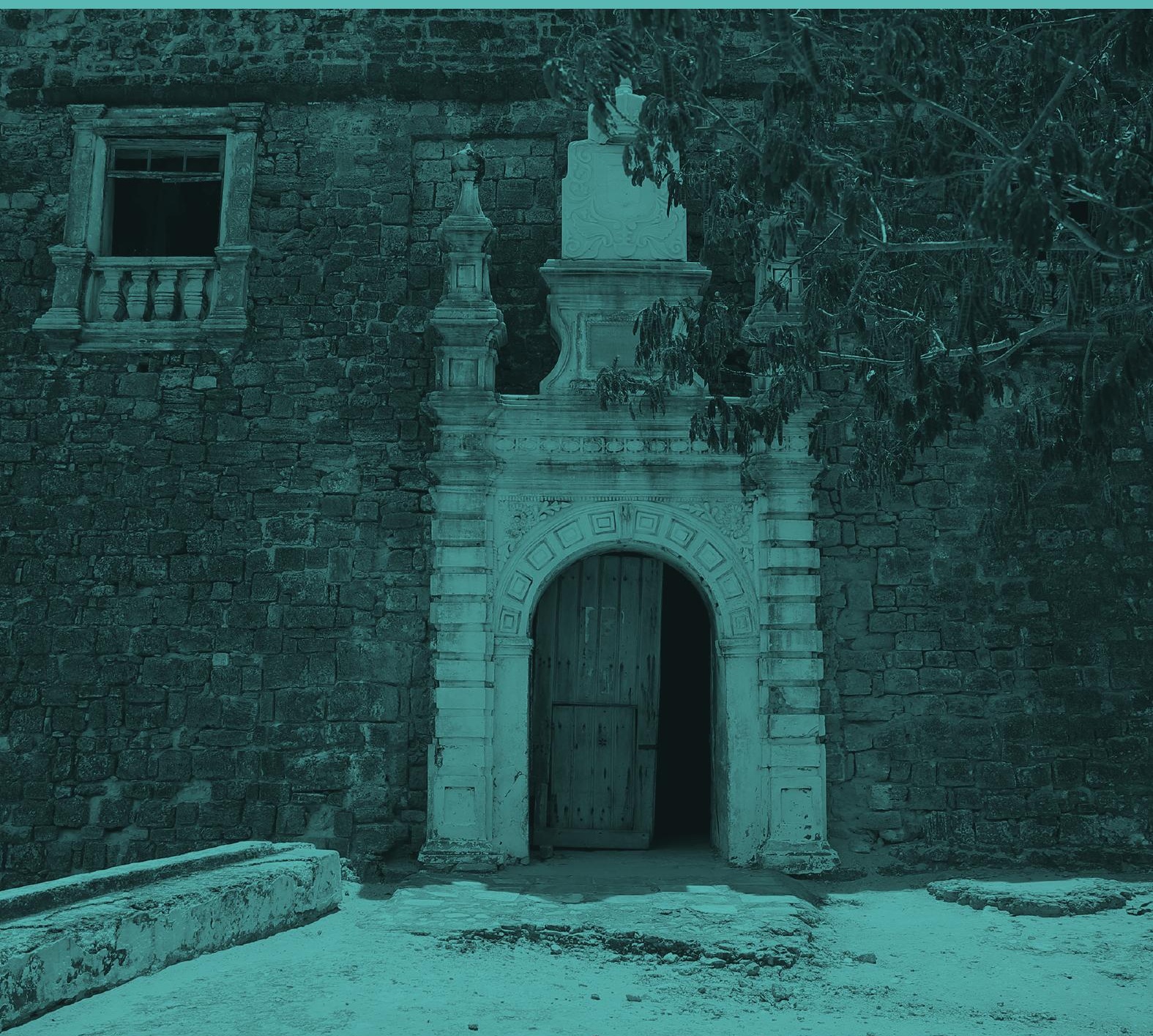




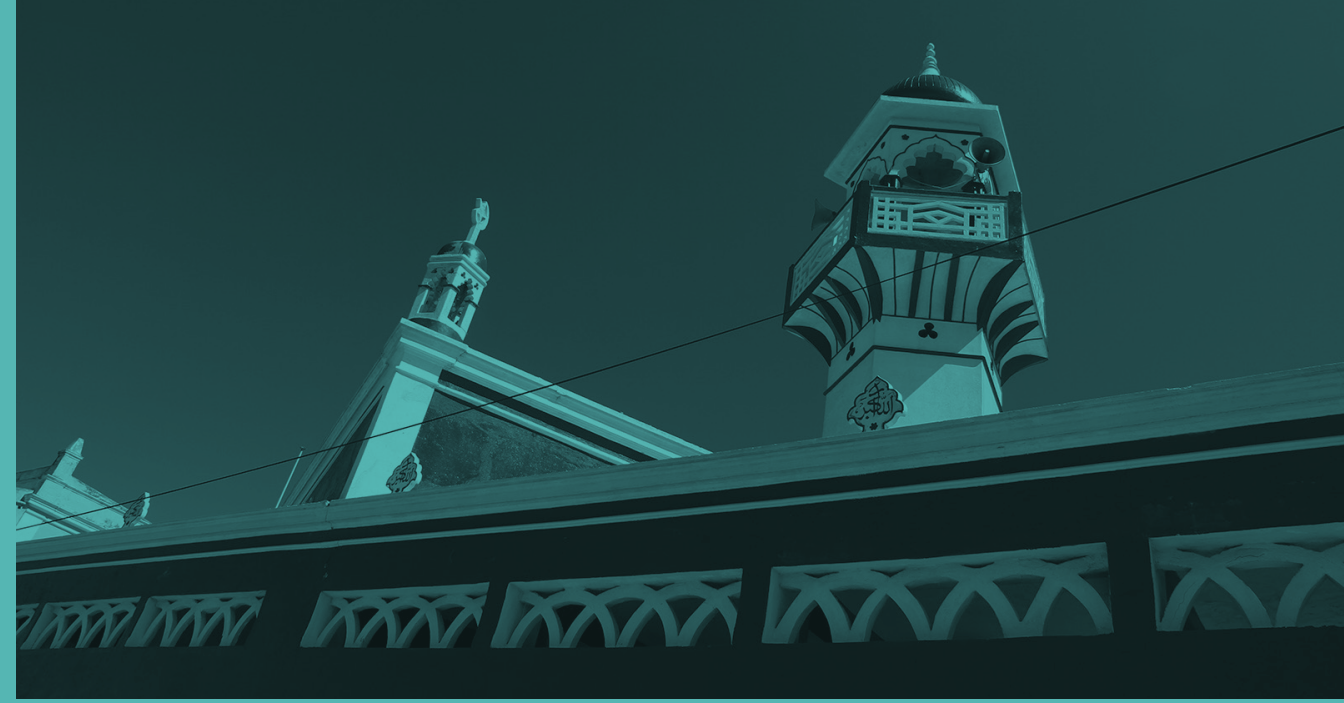

O sistema de gestão discutido levou em conta a atual abordagem da UNESCO, que considera as Cidades Históricas Vivas contra a visão estática monumentalista do passado, em benefício das comunidades locais. Contudo, é indispensável que esta nova abordagem seja monitorizada, mediando os limites entre a desejável mudança e a salvaguarda da integridade e da autenticidade, conforme definido com a inscrição da llha de Moçambique na Lista do Património Mundial da UNESCO.

A discussão sobre o sistema de gestão do património edificado da Ilha, aqui apresentada, não está concluída, devendo ainda contemplar a articulação de várias leis existentes em Moçambique nas áreas do património cultural e natural, alargando-se para os dispositivos normativos (como as posturas camarárias e as formas de implementação) através de memorandos, acordos e outras, no quadro das parcerias público-privadas.

Durante as celebrações do $10^{\circ}$ aniversário do Fundo Africano para o Património Mundial, que decorreu na África do Sul em 2016, foi também vincada a necessidade da combinação das várias convenções da UNESCO que protegem o património Mundial, para um sistema de gestão mais eficiente, nas suas vertentes tangível e intangível. Para além da Convenção de 1972 na discussão futura do sistema de gestão do património edificado, afiguram-se pertinentes outras convenções, designadamente sobre o Património Cultural Intangível (UNESCO, 2003) e sobre a Diversidade das Expressões Culturais (UNESCO, 2005). Estas Convenções são o veículo de transmissão de conteúdos e da interação cultural com vários povos, no que ao património edificado da llha diz respeito. 


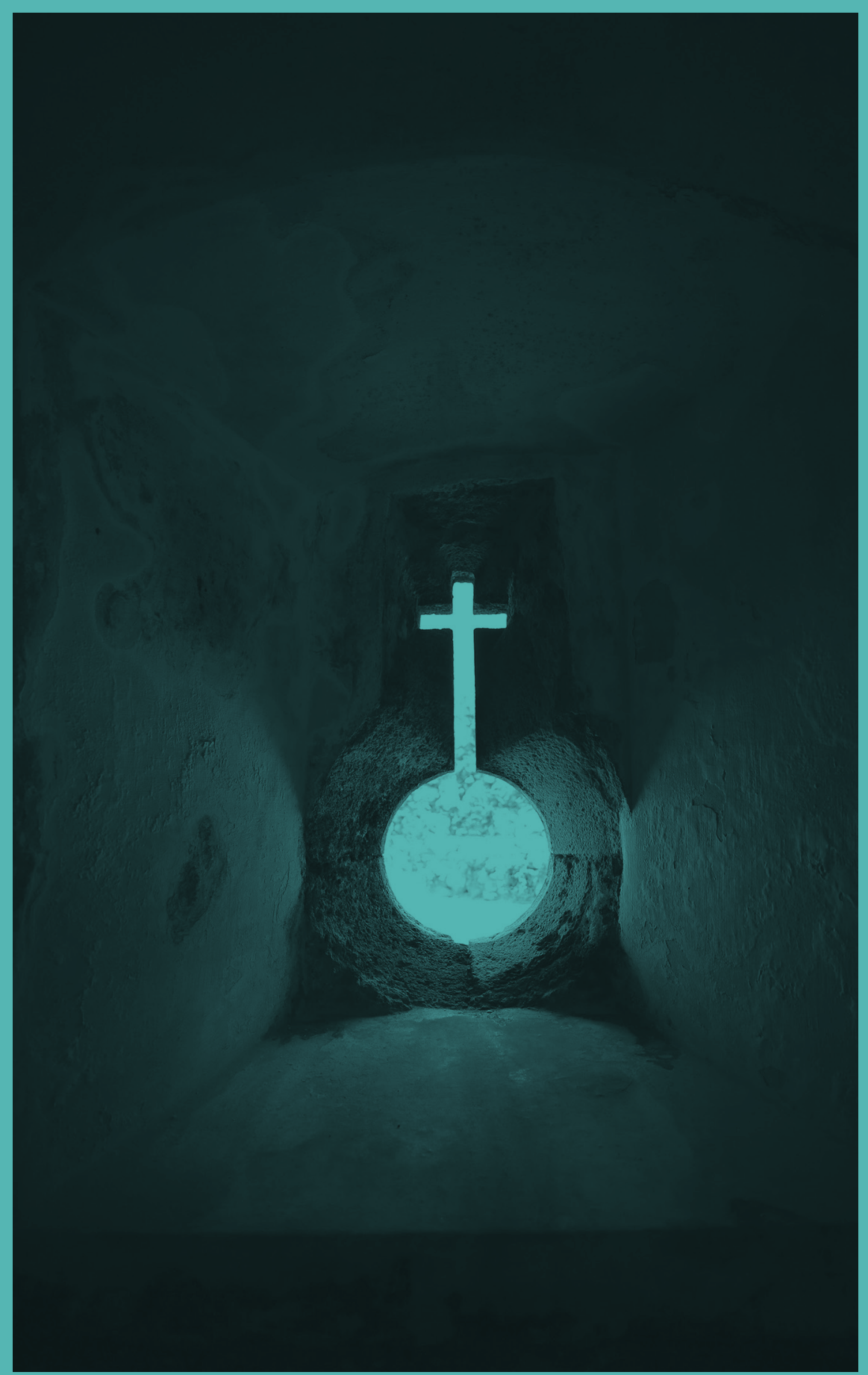




\section{REFERÊNCIAS BILBIOGRÁFICAS}

Decreto $n .{ }^{\circ}$ 27/2006 de 13 de julho (aprova o Estatuto Específico da llha de Moçambique).

Decreto $n .{ }^{\circ}$ 28/2006 de 13 de julho (cria o Gabinete de Conservação da llha de Moçambique e aprova o respetivo Estatuto Orgânico).

Decreto $n$. $^{\circ}$ 54/2016, de 28 de novembro (aprova o Regulamento sobre a Classificação e Gestão do Património Edificado e Paisagístico da llha de Moçambique. Boletim da República n. ${ }^{\circ} 142$ (I)).

Decreto $n$. ${ }^{\circ 5} / 2016$, de 28 de novembro (aprova o Regulamento sobre a Gestão de Bens Culturais Imóveis. Boletim da República n. ${ }^{\circ} 142$ (I)).

ELOUNDOU, Lazare; WEYDT, Jana (eds.) (2009), Reabilitação da Fortaleza da Ilha de Moçambique. Paris: UNESCO World Heritage Centre.

JOPELA, Albino (2006), Custódia tradicional do património arqueológico na província de Manica: experiências e práticas sobre as pinturas rupestres no Distrito de Manica, 1943-2005. Dissertação de Licenciatura, apresentada ao Departamento de História da UEM, Maputo.

JOPELA, Albino (2014), "Definição de conceitos-chave", in Solange Macamo e Albino Jopela (coords.), Manual de Conservação do Património Cultural Imóvel em Moçambique. Maputo: Ministério de Cultura, Direção Nacional de Património Cultural.

JOPELA, Albino; RAKOTOMAMONJY, Bakonirina (coords.) (2014) Plano de Gestão e Conservação da Ilha de Moçambique 2010-2014. Maputo: Ministério da Cultura.

Lei . $^{\circ} 10 / 88$ de 22 de dezembro (determina a proteção legal dos bens materiais e imateriais do Património Cultural Moçambicano. Boletim da República n. 50 (I Série)).

MACAMO, Solange (coord.) (2014), Ilha de Moçambique, Património Mundial. Maputo: Ministério da Cultura.

MACHADO, Jurema; BRAGA, Sylvia (2010), Comunicação e Cidades Patrimônio Mundial no Brasil. Brasília: MONUMENTA, IPHAN.

NDORO, Webber; KIRIAMA, Herman (2008), "Management mechanisms in heritage legislation" in Webber Ndoro et al. (eds.), Cultural Heritage and the Law. Protecting Immovable Heritage in English-Speaking Countries of Sub-Saharan Africa. Paris: UNESCO World Heritage Centre, 53-64.

NGUIRAZI, Teodato (2008). Conservation of Traditional Buildings on the Island of Mozambique: A Case Study of Macuti City. Harare: University of Zimbabwe. 
OERS, Ron van (2013), "Swahili Historic Urban Landscapes-Apllying HUL in East Africa" in Ron van Oers e Sachiko Haraguchi (eds.), Swahili Historic Urban Landscapes. Report on the Historic Urban Landscape Workhops and Field Activities on the Swahili Coast in East Africa 2011-2012. Paris: UNESCO World Heritage Centre, 6-19.

Resolução 12/2010 (aprova a Política de Monumentos, Boletim da República $\mathrm{n}^{\circ} 59$, de 27 de abril de 2010).

Retrospective Statement of Outstanding Universal Value for Island of Mozambique (2011). Paris: UNESCO World Heritage Centre.

RODERS, Ana Pereira (2013), "Lessons from the Island of Mozambique on Limits of Acceptable Change" in Ron van Oers e Sachiko Haraguchi (eds.), Swahili Historic Urban Landscapes. Report on the Historic Urban Landscape Workhops and Field Activities on the Swahili Coast in East Africa 2011-2012. Paris: UNESCO World Heritage Centre, 20-40.

ROSSA, Walter; RIBEIRO Margarida Calafate (2015), "Modos de Olhar" in Walter Rossa e Margarida Calafate Ribeiro (orgs.), Patrimónios de Influência Portuguesa: modos de olhar. Coimbra: Imprensa da Universidade de Coimbra, 11-35.

Second Cycle of the World Heritage Periodic Reporting for Africa (2010). Subregional meeting for Southern Africa. Windhoek: Namibia.

Secretaria de Estado da Cultura - Moçambique/ Arkitektskolen I Aarhus 1985. Ilha de Moçambique - Relatório/ Report 1982-85 ("Livro Azul").

UNESCO (1972), Convenção para a Protecção do Património Cultural e Natural Mundial. Paris: UNESCO World Heritage Centre.

UNESCO (2003), Convenção para a Salvaguarda do Património Cultural Intangivel. Paris: UNESCO World Heritage Centre.

UNESCO (2005), Convenção sobre a Diversidade das Expressões Culturais. Paris: UNESCO World Heritage Centre.

UNESCO (2008), Operational Guidelines for the Implementation of the World Heritage Convention. Paris: UNESCO World Heritage Centre.

UNESCO (2011), Recomendação sobre a Paisagem Urbana Histórica. Paris: UNESCO World Heritage Centre.

UNESCO (2013), Managing Cultural World Heritage. World Heritage Resource Manual. Paris: UNESCO World Heritage Centre. 


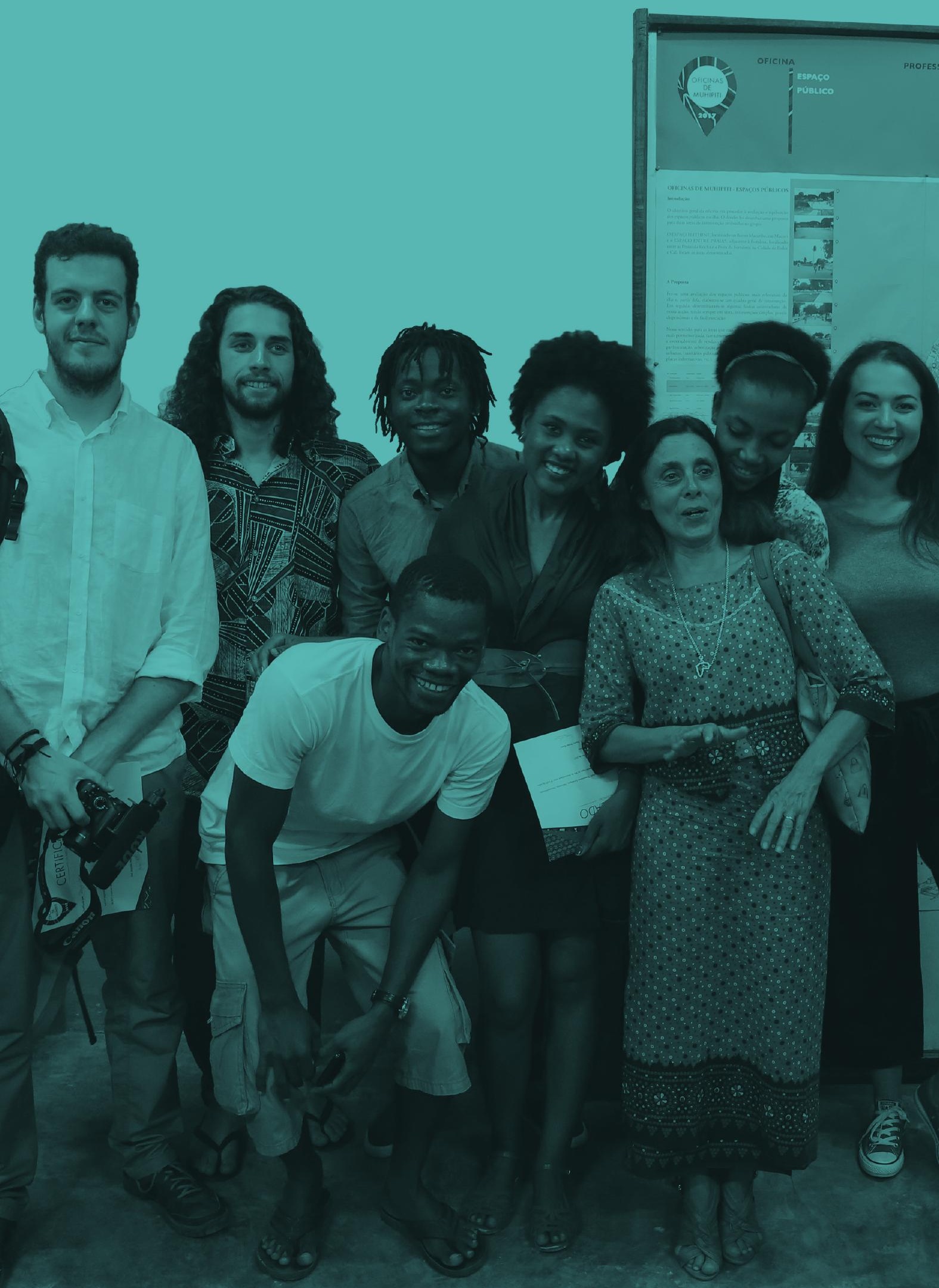



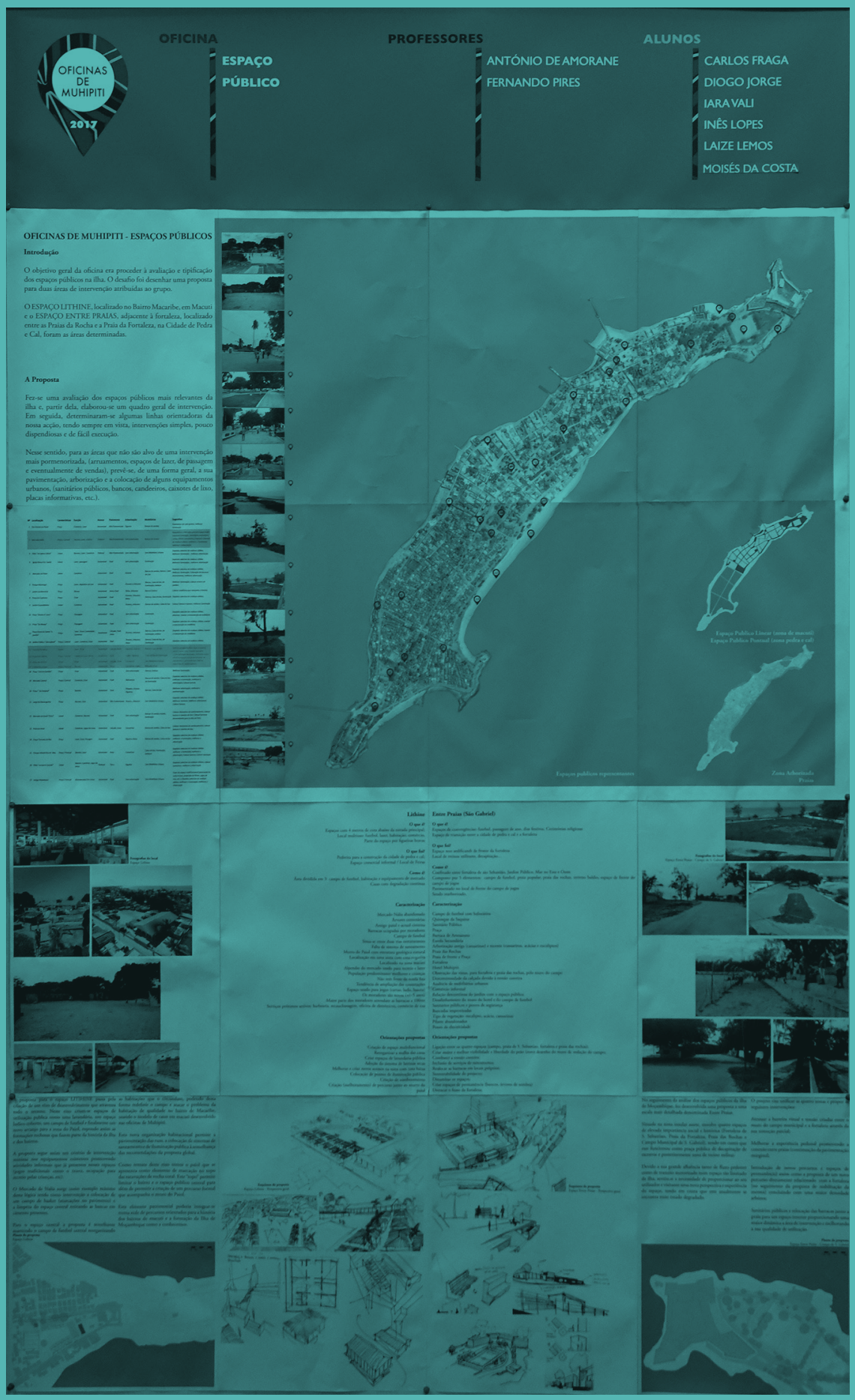


\section{ESPAÇO PÚBLICO}

\section{António de Amurane Fernando Pires}

\section{Missão-encomenda previamente formulada}

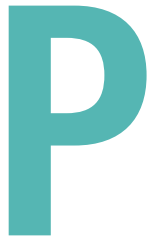

retende-se que, a partir de uma avaliação e tipificação de situações dos espaços públicos da Ilha, esta oficina produza um quadro de intervenção com exercícioscaso muito diversos que ilustrem o tipo e estratégia que se afiguram necessários empreender. É fundamental que, nessa avaliação prévia, sejam identificados os usos atuais e potenciais dos espaços existentes, no que não são de forma alguma descartáveis as questões de ordem simbólica e de representação. Chama-se a atenção para a necessidade de levar em linha de conta: custos das soluções, fácil acesso aos materiais e à mão de obra especializada necessária, durabilidade face aos requisitos locais, tipificação de soluções por forma a reduzir custos e dificuldades de gestão de estaleiro e armazém de reparações e reposições, impacto estético num bem com a distinção patrimonial detida pela Ilha, otimização e reutilização de materiais e/ ou soluções existentes. Em suma, um apelo ao bom senso em que a excelência do desenho deve resultar da aplicabilidade e não do efeito em projeto. Seria louvável que um dos resultados do trabalho desta oficina fosse um manual prático para a qualificação do espaço público da Ilha, à imagem de muitas que se conhecem, razão pelo qual a equipa se deverá ter previamente inteirado de alguns exemplos. 


\section{INTRODUÇÃO}

A partir de uma avaliação e tipificação de situações dos espaços públicos da Ilha, esta oficina teve como tarefa a produção de um quadro de intervenções, com dois exercícios-casos muito diversos, que ilustrem o tipo e estratégia que se afiguram necessários empreender. Nessa avaliação prévia seriam identificados os usos atuais e potenciais dos espaços existentes, incluindo as questões de ordem simbólica e de representação. Era, desde logo, importante levar em linha de conta os custos das soluções, a acessibilidade aos materiais e à mão de obra especializada necessária, a durabilidade face aos requisitos locais, a tipificação de soluções (reduzindo custos e dificuldades de gestão de estaleiro e armazém), o impacto estético num bem com a distinção patrimonial detida pela llha, a otimização e a reutilização de materiais e/ou soluções existentes.

Note-se que as características dos espaços públicos da llha abarcam, naturalmente, as várias dimensões temporais e espaciais que foram acompanhando a dinâmica de ocupação de diferentes povos que a cruzaram ou se foram estabelecendo nesta área, o que nos alerta para a existência de uma multiplicidade de culturas espaciais que é preciso ter em conta. Um segundo aspeto a não descurar é o facto de a llha ter um clima tropical húmido e um ecossistema próprio que, no seu conjunto, determinou características construtivas específicas do seu edificado, tanto ao nível de estruturas e materiais de construção, quanto à forma da distribuição dos espaços. Por isso, o desenho de uma estratégia de intervenção para os espaços públicos da Ilha passa, necessariamente, por ter em conta estes aspetos, constituindo uma ferramenta importante para a salvaguarda e desenvolvimento do seu património material e imaterial.

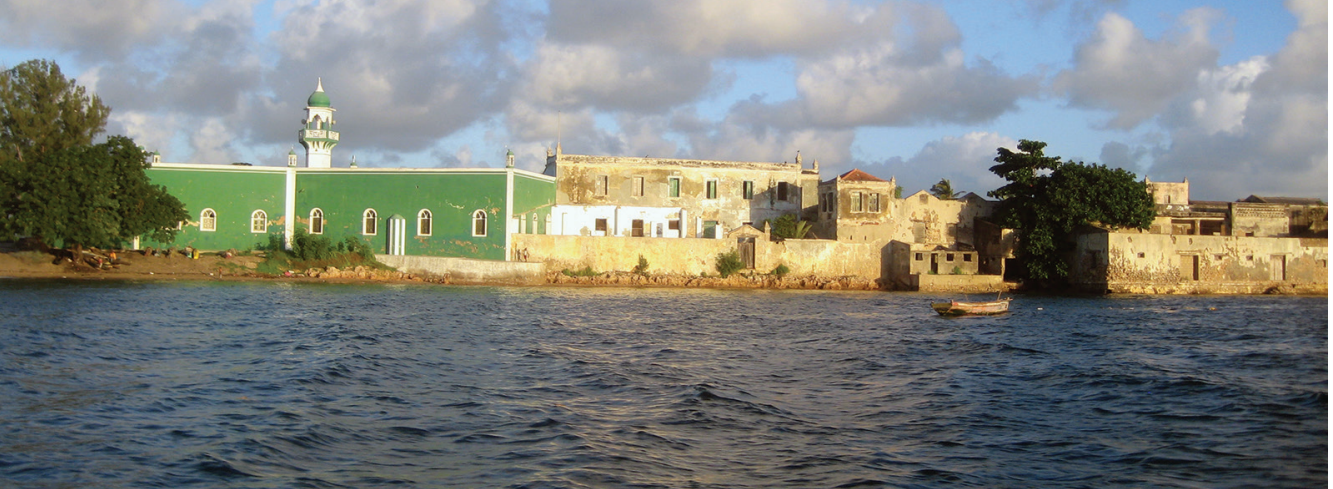


A estrutura urbanística da llha é composta por dois setores com características bem distintas: a cidade de pedra e cal e a cidade de macuti. A cidade de macuti ocupa a parte a sul do hospital, foi o espaço onde maioritariamente se instalou a população autóctone em casas de tipos tradicionais, cuja marca fundamental é, precisamente, as coberturas em macuti. A cidade de pedra e cal ocupa a área restante, a norte, onde não só se instalaram os colonizadores europeus e os seus equipamentos, mas também comerciantes das mais diversas origens. Por isso, ali se encontram os edifícios mais emblemáticos da cidade.

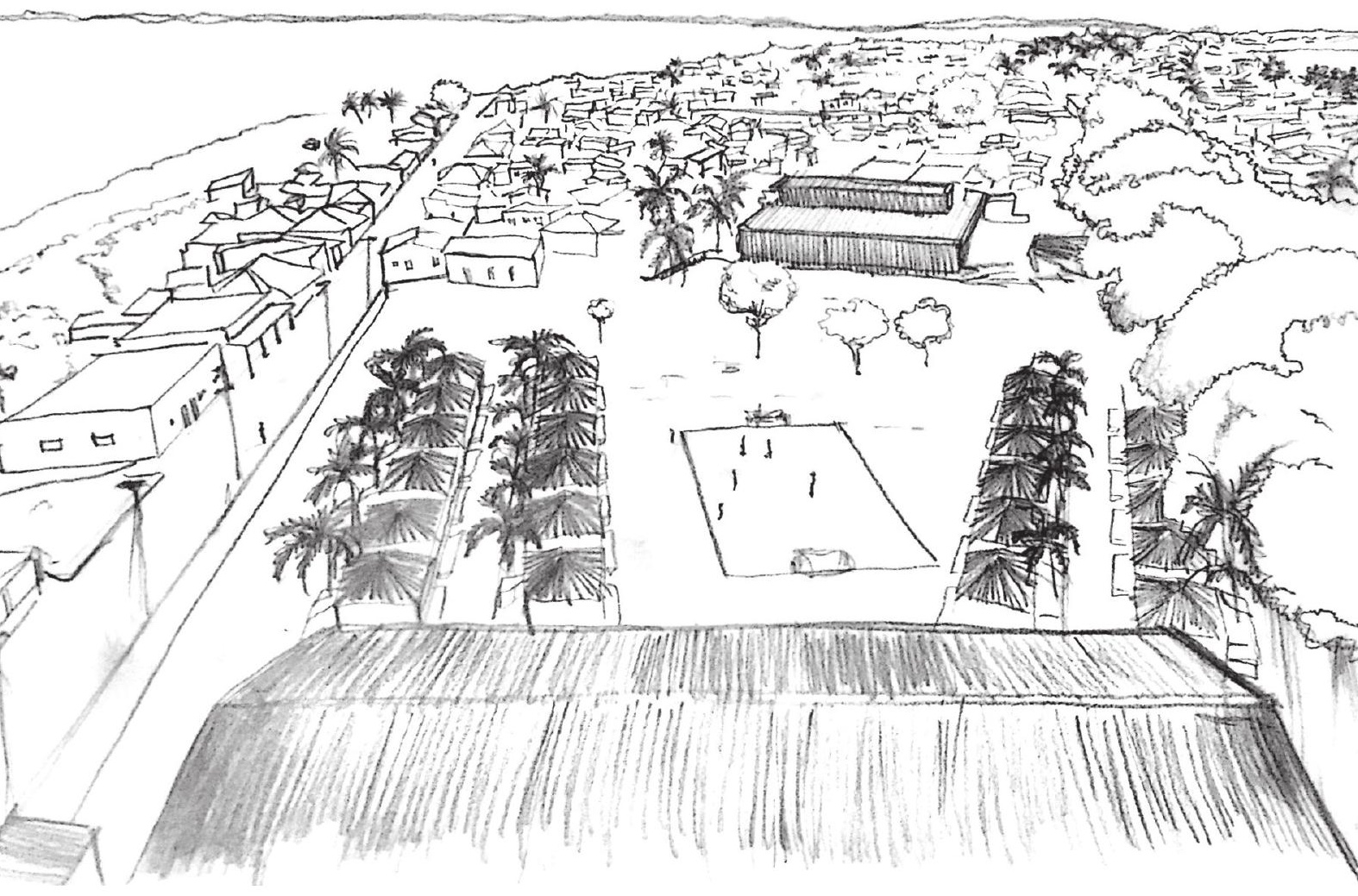


Perante esta realidade espacial, o desafio principal desta oficina foi encontrar respostas que levem em consideração essas diferenças, mas que também visem a integração da cidade, de forma a que a população usufrua dos espaços públicos como um todo. É ainda necessário potenciar e desenvolver a consolidação de diferentes tipos de espaços públicos servindo e estruturando toda a llha.

Da análise efetuada tornou-se claro que o elemento mais importante da rede dos espaços públicos da Ilha, até porque assegura a ligação entre as cidades, é o eixo formado pela avenida 25 de Junho. 0 troço que atravessa a cidade de macuti é, seguramente, um dos mais importantes lugares de vivência urbana, sendo também ali que se processa parte significativa do comércio informal. Já na cidade de pedra e cal, a avenida vai conectando os principais largos e praças.

Esse eixo funciona ainda como divisor longitudinal da Ilha.
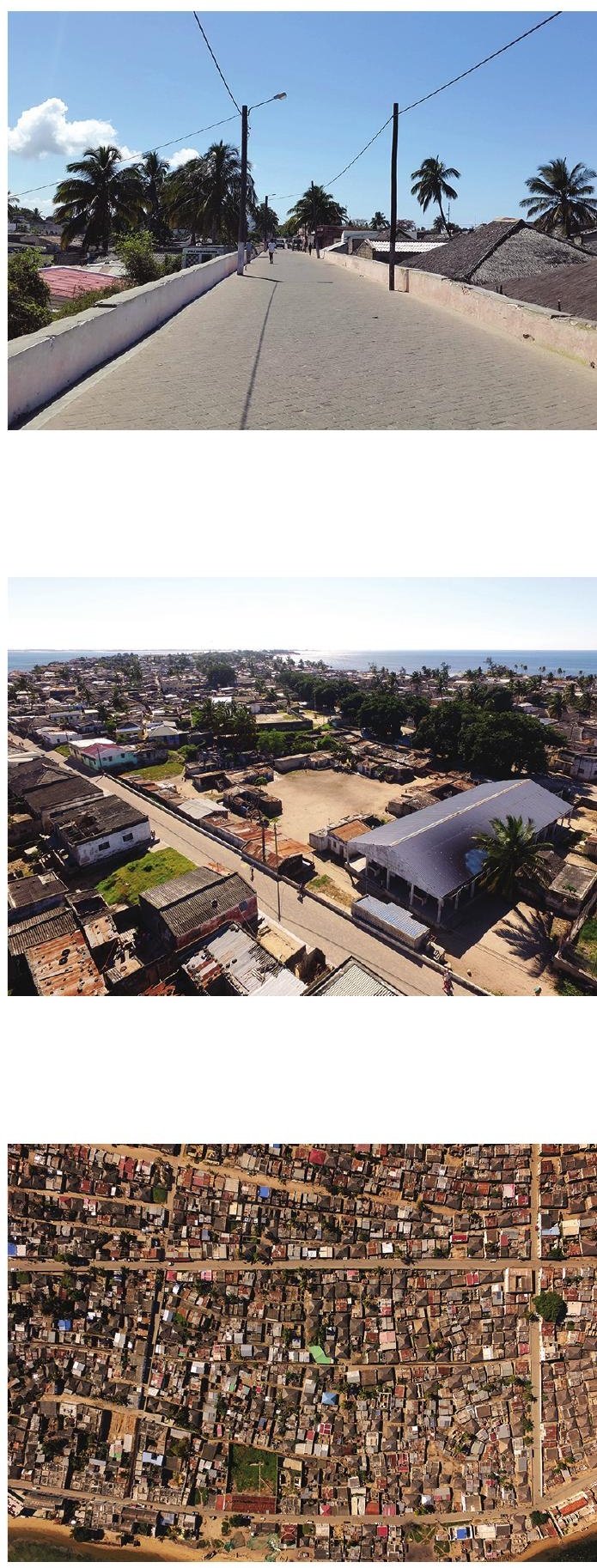
O tecido urbano da cidade de pedra e cal é formado por um sistema de quarteirões, largos e praças, estruturados e interligados por ruas e travessas que asseguram a conexão entre a costa e a contracosta. Os mais emblemáticos edifícios da cidade - Fortaleza de São Sebastião, Palácio, Capela e Torre de São Paulo, Igreja da Misericórdia, Convento de São Domingos, Câmara - tendem a articular-se com praças e largos como, por exemplo, o Campo de São Rafael, o Largo de S. Paulo ou o Largo do Mercado. São espaços públicos razoavelmente definidos, estruturados e equipados mas, conforme já registado, pouco usados pela população.

Foi a partir desta, aqui sumarizada, visão de conjunto, que a oficina teve de escolher os espaços sobre os quais desenvolver as suas propostas. Procuraram-se casos passíveis de intervenções simples e concernentes com a realidade local, levando-se ainda em conta o facto de estarem em curso ações do mesmo escopo por parte do Município, com o apoio da UCCLA, em relação às quais seria obviamente desajustado coincidir ou colidir.
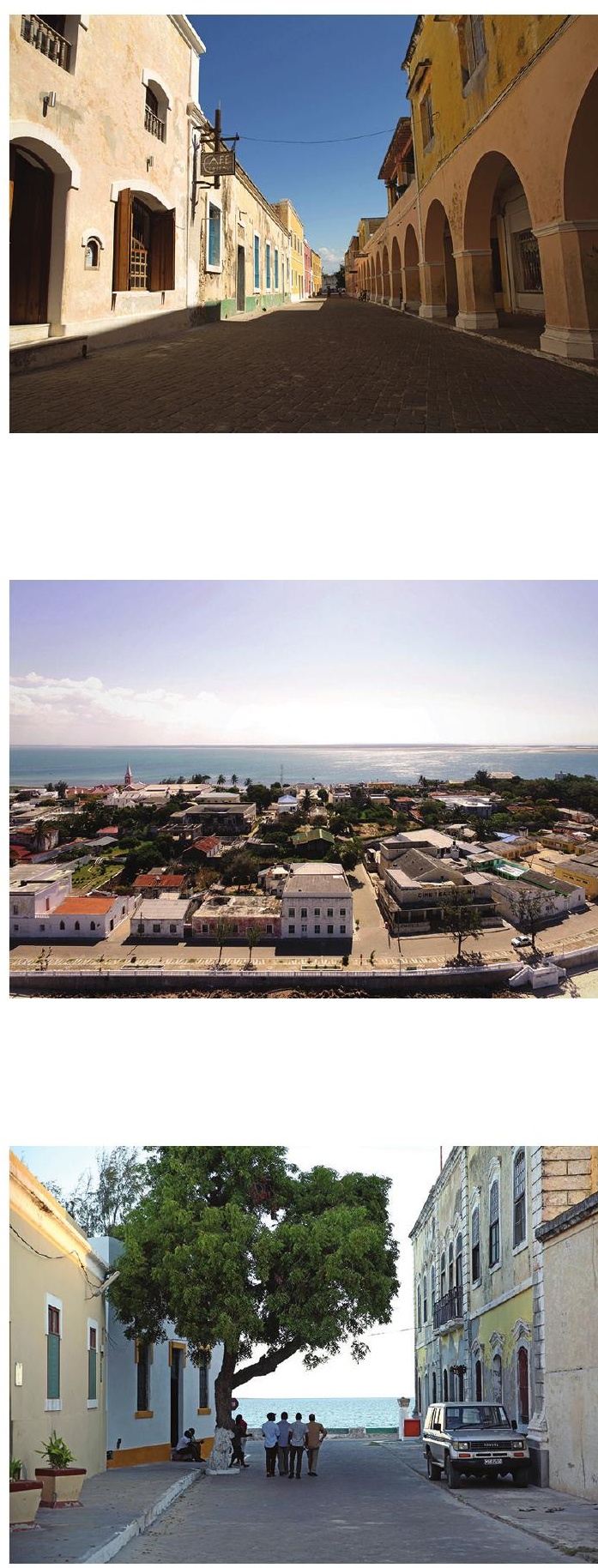
Foi assim que se selecionou o Campo de S. Gabriel, na cidade de pedra e cal (descampado adjacente à fortaleza, o qual foi denominado espaço entre praias), e o aqui designado espaço Nália (semear), no Bairro de Macaribe da cidade de macuti (constituído pelo mercado Nália e áreas adjacentes). São dois espaços que apresentam aspetos bastantes peculiares do ponto de vista dos seus processos de formação e das estruturas socioeconómicas e formais, requerendo, assim, diferentes formas de intervenção.

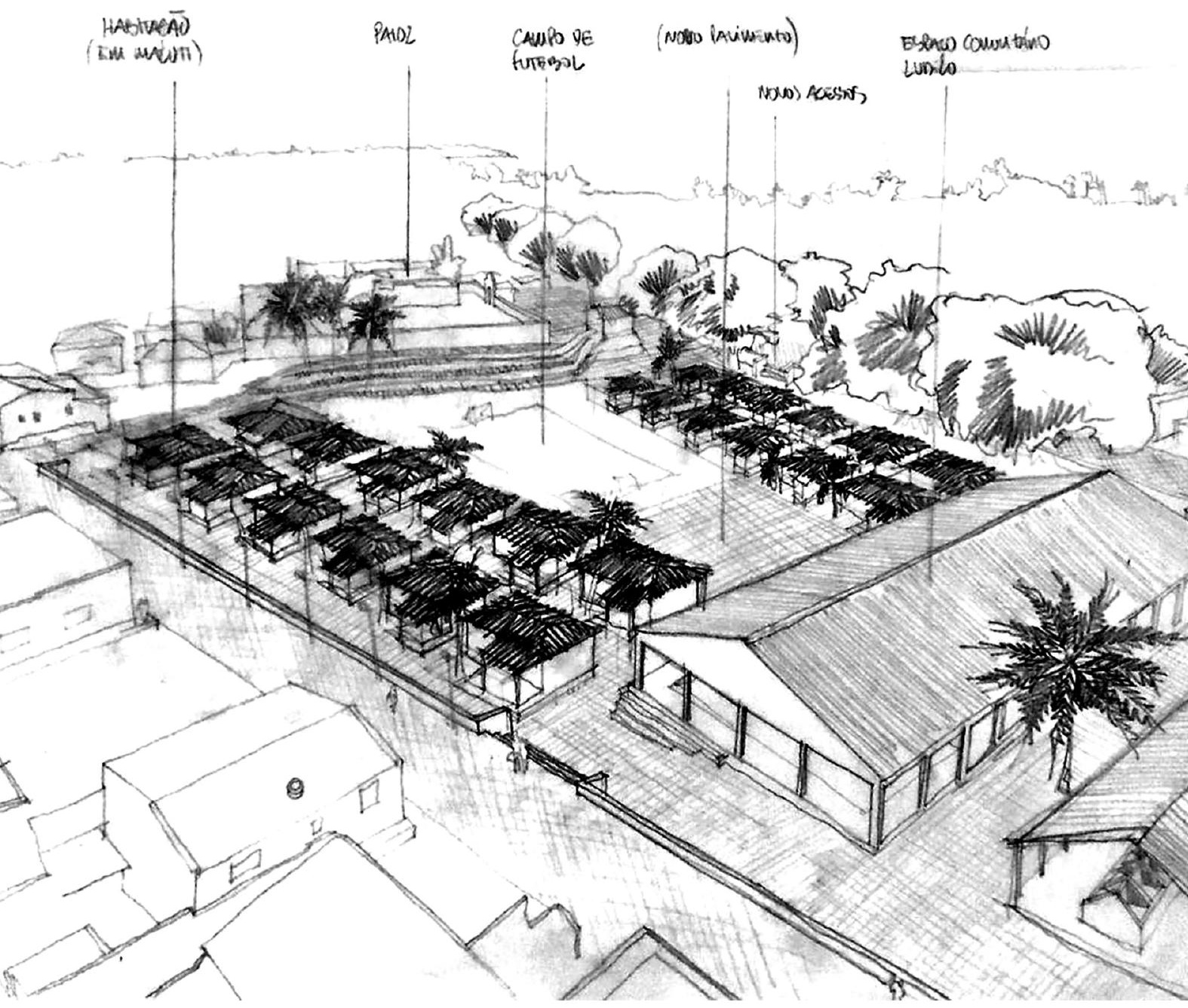




\section{AS PROPOSTAS}

\subsection{Espaço Nália}

O espaço Nália é delimitado a sudeste pela Avenida 25 de Junho, a noroeste pela Rua da Solidariedade, a nordeste pela Cisterna e a sudoeste pela antiga MCel. É um espaço bem contido, até porque está cerca de quatro metros abaixo das ruas que o circundam, o que dificulta a circulação de veículos, a sua drenagem e saneamento, em especial quando ocorrem chuvas intensas, sendo objeto de frquentes inundações. No espaço está construído o Mercado Nália, hoje inativo, correspondendo a um conjunto coberto de bancadas em betão utilizado por crianças e adultos como espaço de lazer e descanso. No perímetro existem várias construções precárias, por regra arrendadas. Mas o fulcro da área é um espaço vazio onde se pratica futebol.

A nossa proposta visa uma intervenção contida, integradora e controlada, tendo em conta os edifícios situados na periferia, como são os casos da cisterna e da Capela de São Francisco Xavier, mas também do mercado e até mesmo as construções mais precárias. Pretende-se criar um espaço multifuncional, arborizado e com boa acessibilidade.

Neste sentido e visando uma reorganização espacial, propõe-se a remoção de algumas das construções precárias e construção de novos edifícios para habitação com melhores condições de habitabilidade. Prevê-se a implementação de novos arruamentos que melhorem os acessos e a ventilação do local. Ao longo dos percursos e dos espaços mais desafogados, propõe-se a plantação de árvores de espécies endémicas na região.

Foi considerado fundamental manter o espaço central como lugar para a prática de futebol, acrescentando alguns equipamentos que viabilizem a realização de outros eventos desportivos e culturais. No antigo mercado Nália foi proposta a remoção da maioria das bancadas, com vista à conformação de um espaço amplo e coberto para reuniões comunitárias e prática de desportos de salão (basquetebol, futsal, etc.).

Propõe-se também a instalação de equipamentos públicos, nomeadamente uma lavandaria comunitária, sanitários públicos, bem como a instalação de iluminação pública e de um sistema de recolha de lixo. 


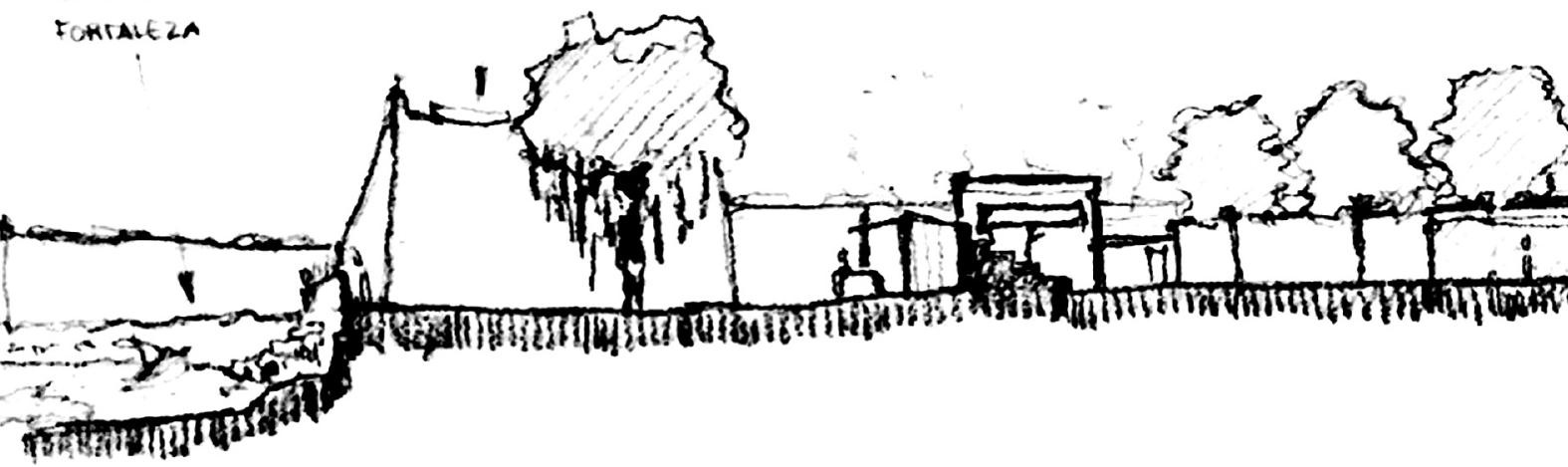

\subsection{Espaço entre praias/ Campo S. Gabriel}

O espaço entre praias aglutina quatro de elevada importância social e histórica: Fortaleza de São Sebastião, Praia da Fortaleza, Praia das Rochas e Campo Municipal de São Gabriel. Este espaço é limitado pela fortaleza, a nordeste, pelo parque, a sudoeste, pela Praia da Fortaleza, a nordeste, e Praia das Rochas, a sudeste. É um amplo descampado, sem construções, pouco utilizado pela população, exceto em dias festivos e de jogos de futebol, nos quais se verifica um elevado afluxo de pessoas e veículos.

A proposta visa catalisar novas perspetivas e experiências espaciais, sendo um dos objetivos centrais a interação das quatro zonas. Para isso, é fundamental atenuar a barreira visual e a tensão criadas entre o muro do campo municipal e a fortaleza, através da sua remoção parcial e o melhoramento da circulação pedonal.

Em termos de acessibilidade, a proposta desenvolve a ligação entre as duas praias, dando continuidade à já existente pavimentação da marginal. Propõe-se a abertura de novos percursos e espaços de permanência e lazer, diretamente relacionados com a fortaleza e de acordo com a proposta de reabilitação produzida pela respetiva oficina. Prevê-se a arborização de toda a área, a colocação de sanitários públicos, assim como a relocalização das barracas existentes junto à praia para um espaço interior, proporcionando maior dinâmica e atração de mais gente ao local.

Em suma, a intervenção pretende promover um espaço único, aglutinando os espaços contíguos de forma harmoniosa e cuidadosa, tendo sempre em conta o ambiente envolvente, as cargas histórica e simbólica e conferindo-Ihe legibilidade e fruição. 


\section{MPO DE}

STEBOL
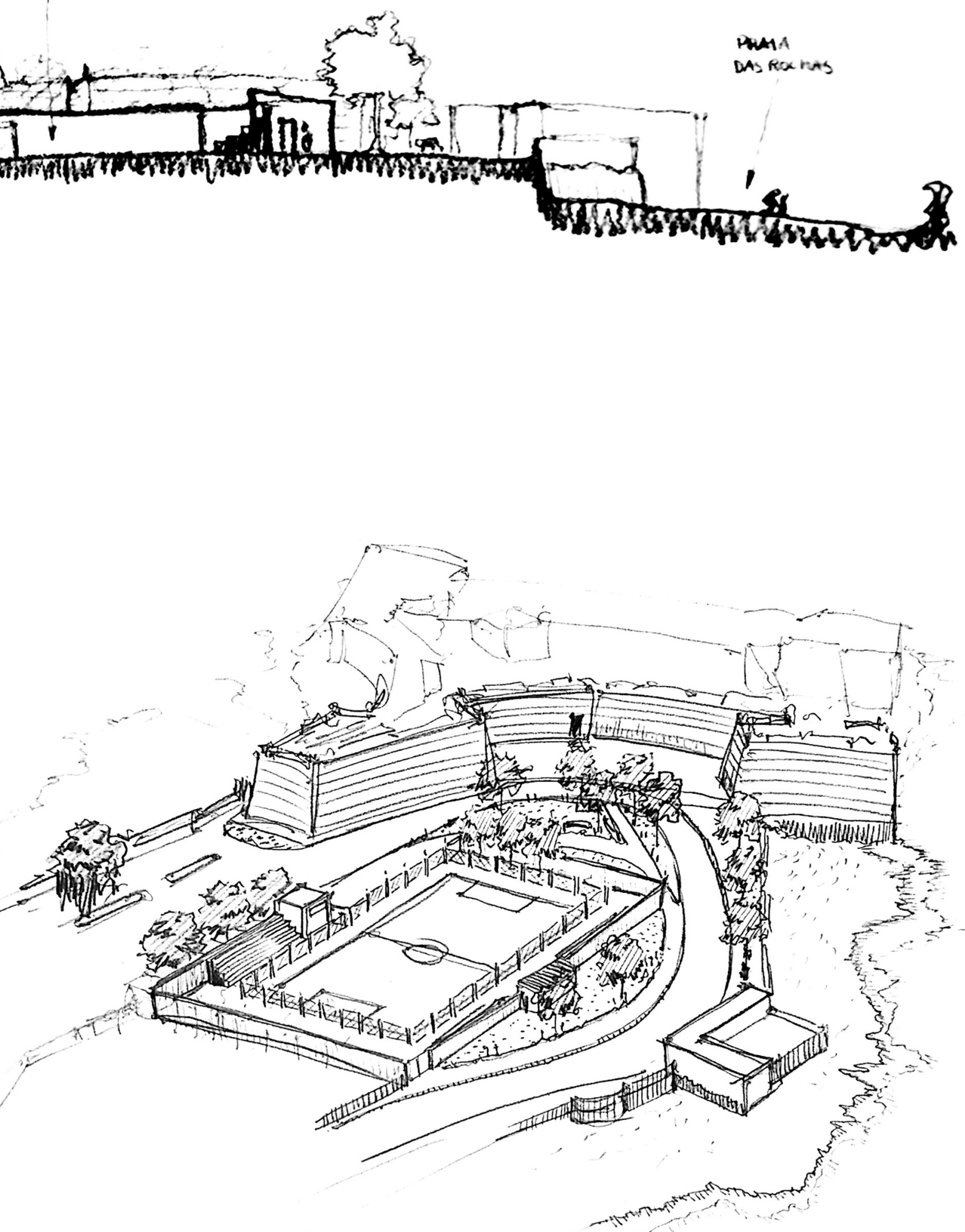


\section{NOTAS FINAIS GERAIS}

Em todo o processo de análise ficou patente que na cidade de pedra e cal os espaços públicos estão formalmente definidos, evidenciandose, porém, uma carência de elementos que potencializem a vivência urbana, mantendo-se a sua amplitude. Nesse sentido, as principais recomendações para a sua melhoria consistem numa seleção de mobiliário urbano, essencial para a vivência desses espaços, nomeadamente momentos de pausa, repouso ou lazer aos transeuntes e utentes habituais. Considerou-se também fundamental melhorar a iluminação pública e incrementar a arborização que é escassa, está doente e envelhecida.

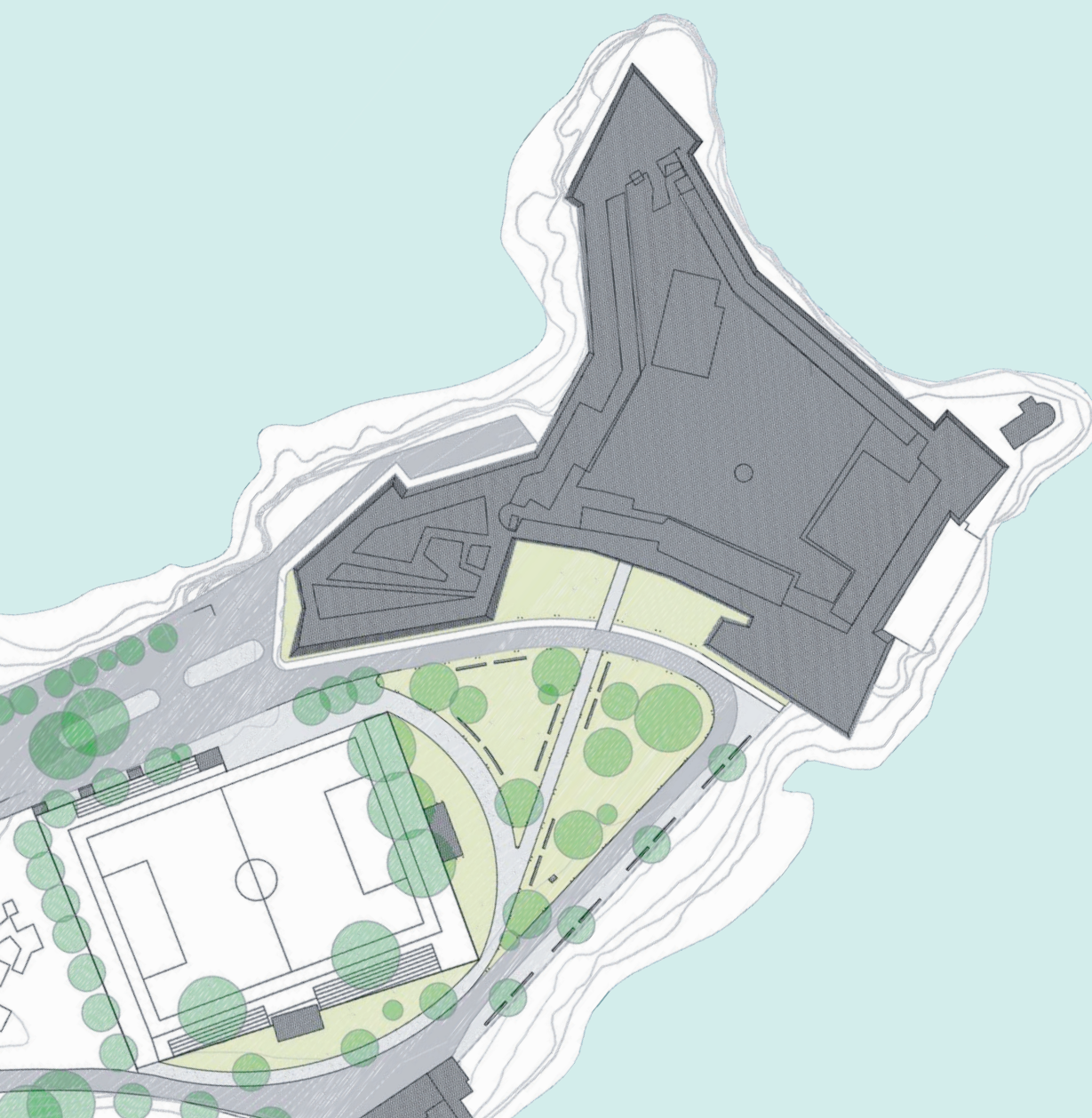


Na cidade de macuti, sem prejuízo das áreas de habitação, os espaços públicos precisam de ser reestruturados e ganhar dimensão. Neste caso, as recomendações são no sentido de se proceder à pavimentação de algumas áreas, evitando o estreitamento acentuado das ruas com novas construções, permitindo maior mobilidade. A arborização dos espaços é, também aqui, essencial para a criação de microclimas e espaços mais agradáveis, sendo também fundamental o melhoramento na iluminação pública.

As intervenções propostas consideram sempre os princípios de adequação técnica, ambiental e cultural, de modo a evitar transformações agressivas ao carácter da própria llha.

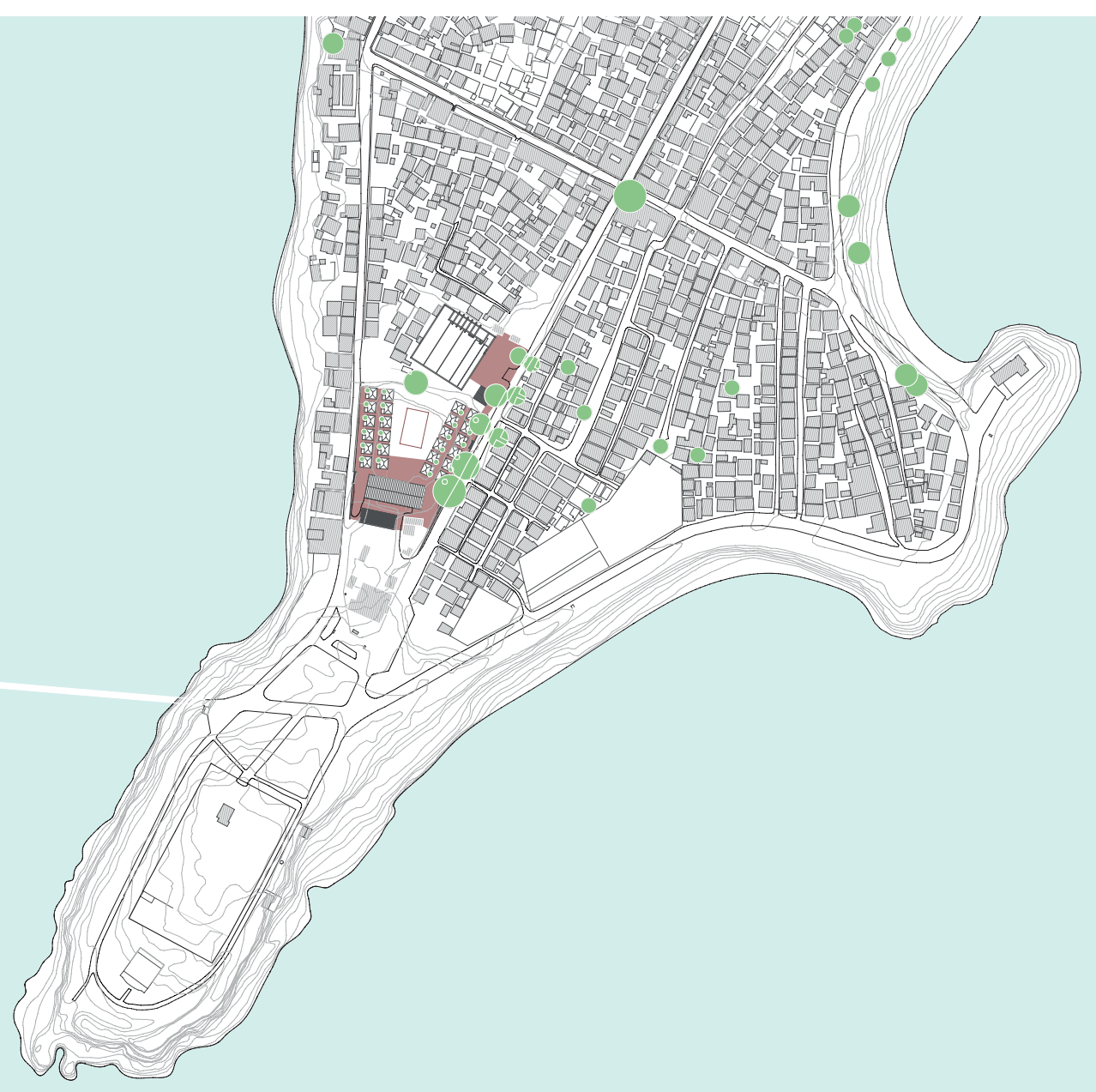




\section{REFERÊNCIAS BIBLIOGRÁFICAS}

CHEN, Arthur et al. (2011), Preliminary study on public spaces in Ilha de Moçambique. Center for World Heritage Studies: University of Minnesota.

LOBATO, Alexandre (1945), A Ilha de Moçambique (Monografia). Lourenço Marques: Imprensa Nacional.

SNPE, Secretaria de Estado da Cultura de Moçambique; Arkitektskolen i Ãrhus, Denmark (1986), Ilha de Moçambique, relatório - Report 198285. Moçambique e Dinamarca: Secretaria de Estado da Cultura e Arkitektskolen i Ãrhus. 


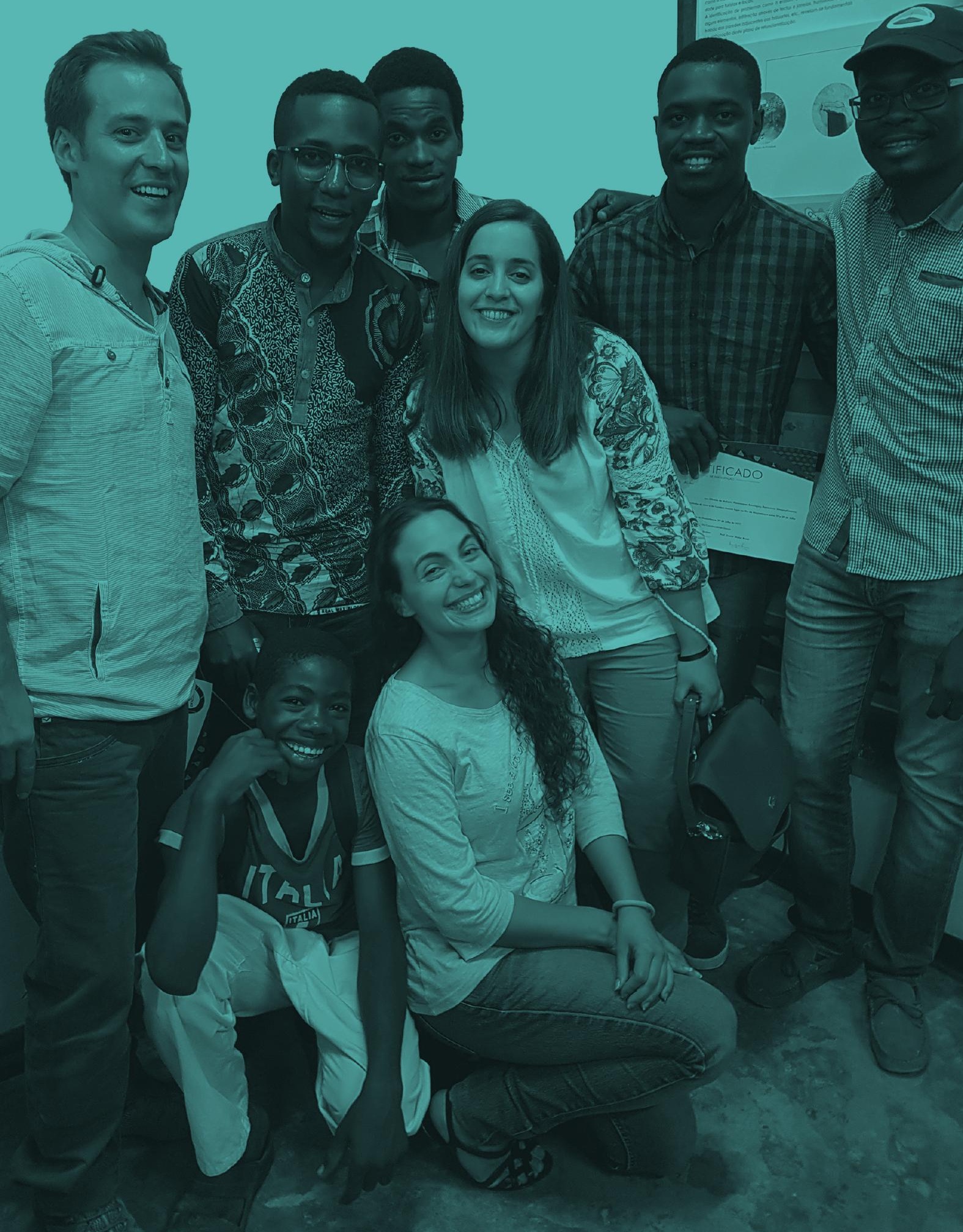




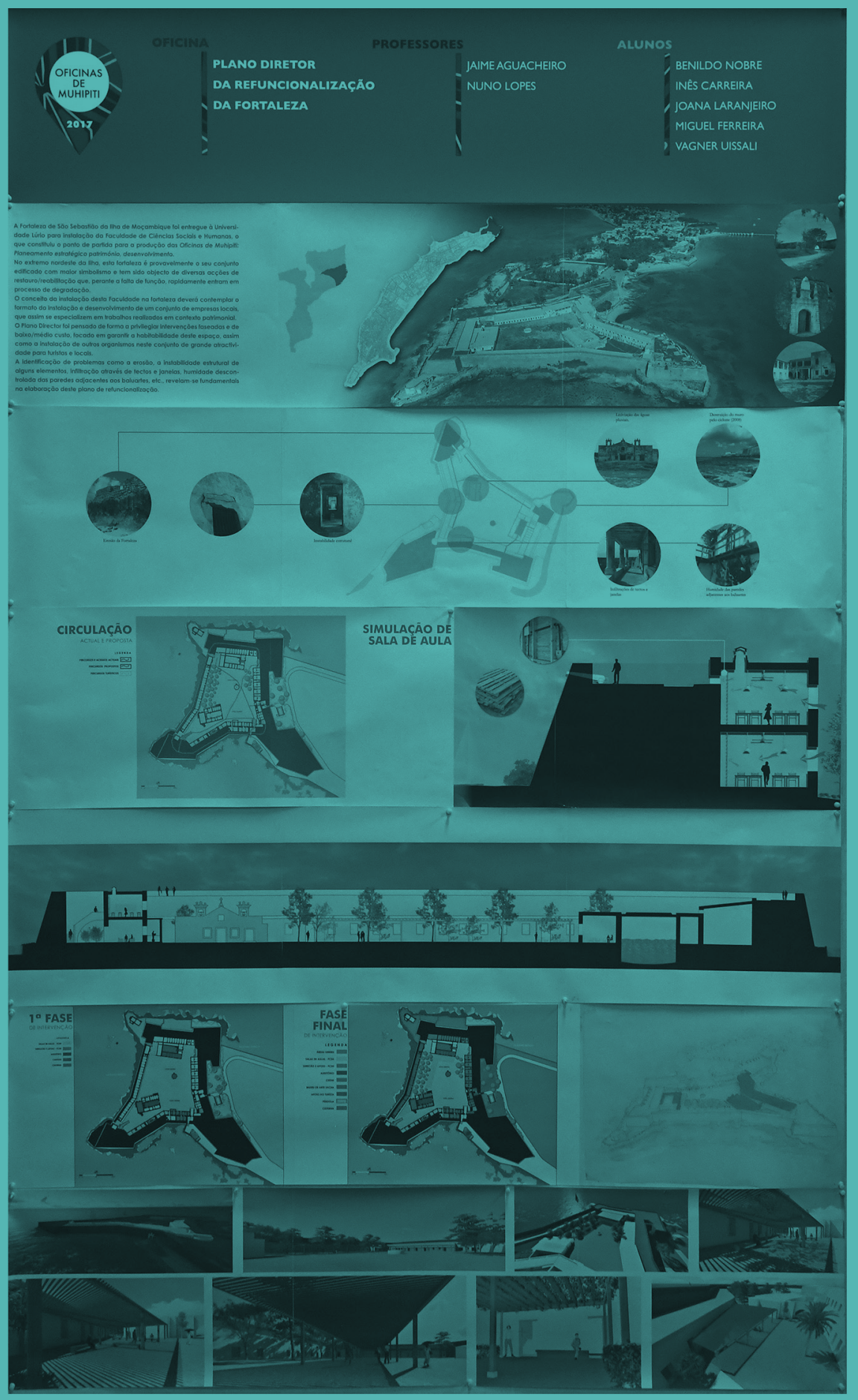




\title{
PLANO DIRETOR DA REFUNCIONALIZAÇÃO DA FORTALEZA
}

\author{
Jaime Aguacheiro \\ Nuno Lopes
}

\author{
Missão-encomenda previamente formulada
}

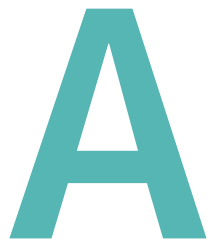

Fortaleza de São Sebastião da llha de Moçambique foi entregue à Universidade Lúrio para instalação da sua Faculdade de Ciências Sociais e Humanas, o que constituiu o ponto de partida para a produção deste evento. A fortaleza é, provavelmente, o conjunto edificado com maior simbolismo da llha e tem sido objeto de diversas ações de restauro elou reabilitação que, perante a falta de função, rapidamente entram em processo de degradação. A instalação da faculdade pode ser a solução ou mais um problema, tudo dependendo do conceito que vier a ser adotado na sua refuncionalização. Na conceção deste evento partiu-se do pressuposto de que o conceito da instalação daquela faculdade na fortaleza deverá contemplar o fomento da instalação e desenvolvimento de um conjunto de empresas locais, que assim se especializem em trabalhos realizados em contexto patrimonial de grande relevância e possam desenvolver a sua atividade não só na construção e manutenção deste conjunto, mas no muito que há para fazer em toda a Ilha. Para tal é crucial que o Plano Diretor que venha a ser adotado privilegie intervenções faseadas e de pequena e/ou média dimensão, e dê indicações muito concretas sobretudo de forma a que o resultado das diversas intervenções, muito provavelmente desfasadas no tempo, resulte harmonioso. Importa ter presente, recolher a informação e dinamizar a interação requeridas pelo facto de estar previsto que outros organismos, que não apenas a universidade, também se instalem na fortaleza e, claro, que se trata de um conjunto com grande atratividade para turistas e locais. 
A fortaleza tem sido objeto de diversas ações de restauro/ reabilitação (Eloudou e Weydt, 2009) que, perante a falta de função, entra rápida e repetidamente num processo de degradação, conforme registado pelo arquiteto José Forjaz no relatório Island of Mozambique: Architectural survey and study on local vernacular architecture (2010, 94-95). Com efeito, apesar das diversas intervenções realizadas há alguns anos (com destaque para o conjunto de ações dirigidas pela fundação japonesa) (Berti, 2014), estas parecem insustentáveis.

Em 2016, a pedido do Reitor da Universidade Lúrio, a FAPF, sob coordenação do arquiteto Maurizio Berti, elaborou um projeto de reutilização cujo elevado custo de obra o tornou inviável. Segundo o relatório Considerações preliminares às obras de restauro e de adaptação necessárias para acomodar a Faculdade de Ciências Sociais e Humanas nos espaços da Fortaleza de São Sebastião na Ilha de Moçambique, essa intervenção de reabilitação (uma área de $4.850 \mathrm{~m}^{2}$ ), teria um custo de USD\$7.275.000. As propostas de ocupação incluem o estabelecimento no complexo da fortaleza da referida faculdade e de outras instituições, assim como a reversão de alguns erros de conservação aí perpetrados.
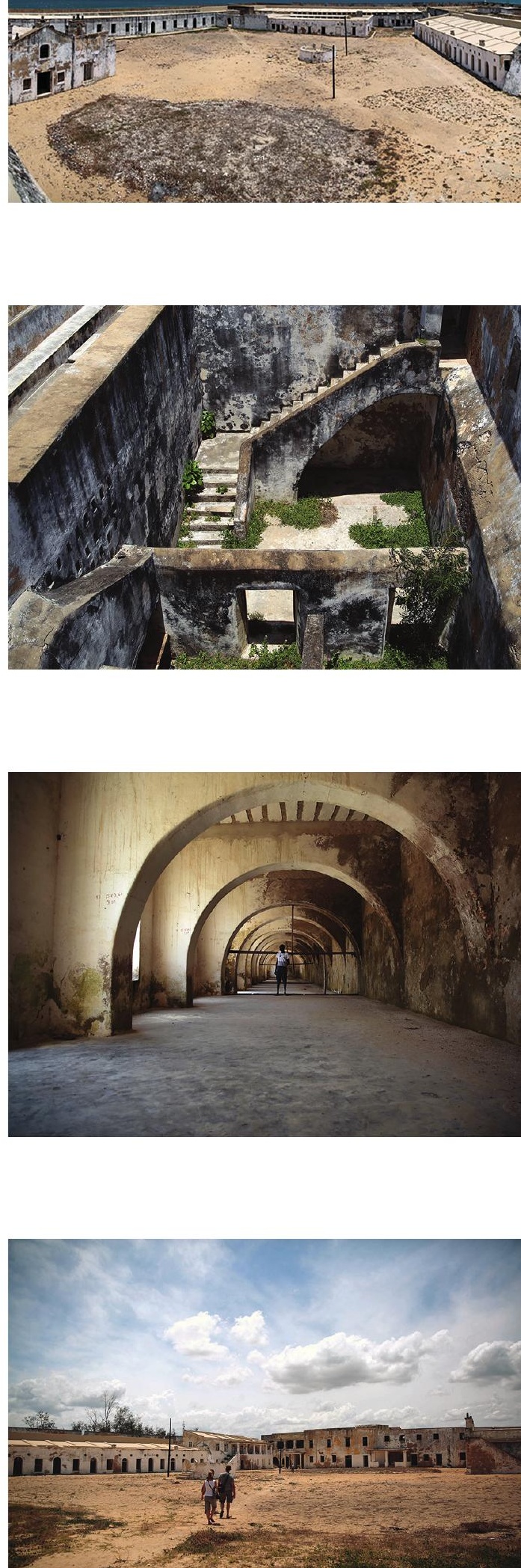


\section{ANÁLISE}

Foi com base nestes dados, na extensa quantidade de estudos sobre a Ilha e a fortaleza, e sensível às situações social, política e económica da Ilha e do país, que a oficina abraçou este desafio. Temos consciência de que a instalação deste polo universitário poderá vir a ser a solução para muitos dos problemas, ou um novo problema a juntar aos restantes, dependendo do conceito e método de implementação que vierem a ser adotados na sua refuncionalização.

A missão destinada a esta oficina consistiu numa espécie de encomenda: tomar como ponto de partida os projetos anteriores e cumprir os desígnios de salvaguarda patrimonial, propor soluções exemplificativas para uma execução de baixo custo e especialização, permitindo promover a contratação de pequenos empreiteiros da região. Nesse sentido, o conceito da instalação da faculdade deverá contemplar o fomento da instalação de um conjunto de empresas locais, que assim se especializem em trabalhos realizados em contexto patrimonial de grande relevância e permitam o desenvolvimento da sua atividade profissional, tanto na construção e manutenção deste conjunto, como no muito que há para fazer em todo o município.

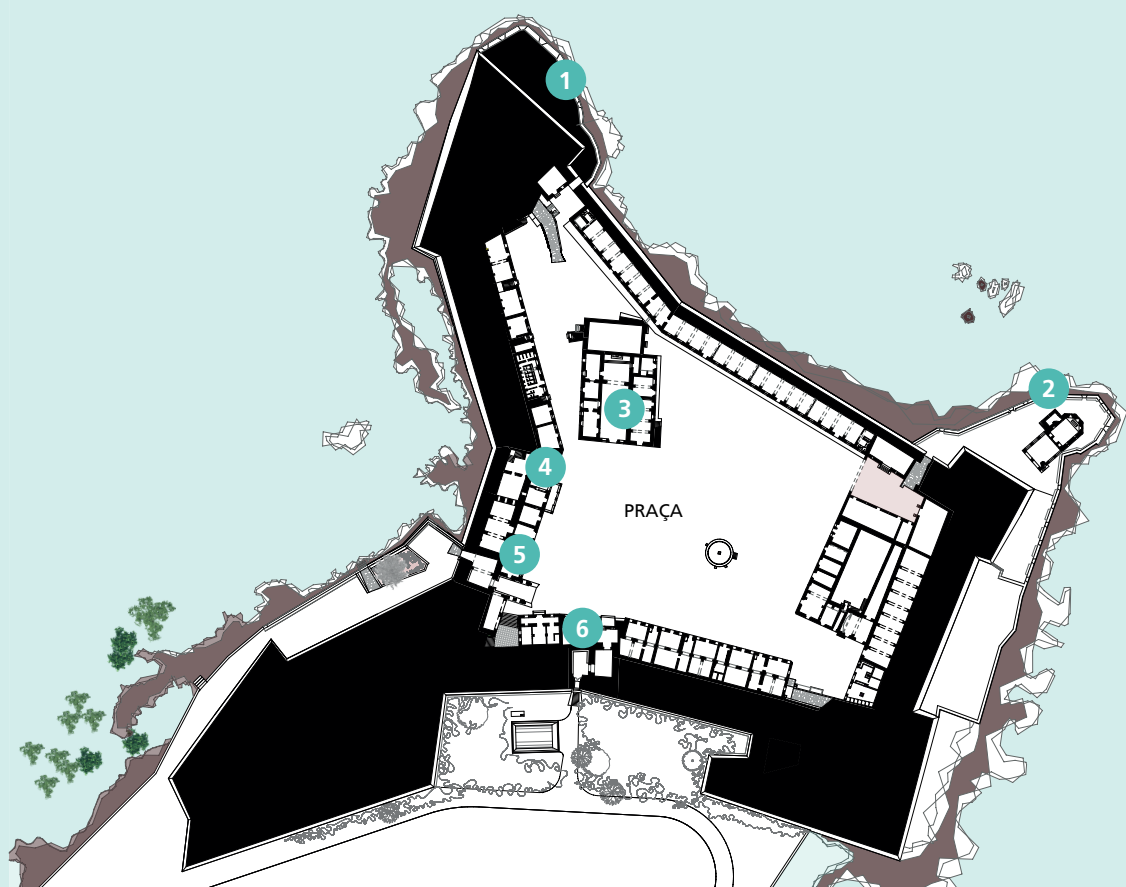


Na análise que a oficina fez às intervenções e propostas anteriores rapidamente percebeu que, embora nem tudo tenha corrido mal, os custos de intervenção, conservação e manutenção são demasiado elevados face aos recursos disponíveis. Verificou-se, com agrado, que as poucas estruturas em atividade - e, portanto, com uma mínima manutenção diária - mantiveram razoável estado geral de conservação. As instalações abandonadas, na grande maioria, apresentam, entre outros, problemas de erosão, instabilidade estrutural, infiltrações, humidade descontrolada (sobretudo em elementos adjacentes aos baluartes) e escassez de ventilação.

\section{LE GENDA}

(1) Erosão da base coralífera

(2) Destruição do muro pelo ciclone (2008)

(3) Lixiviação das águas pluviais

(4) Instabilidade estrutural

5. Infiltrações nos tetos e janelas

6 Humidade das paredes adjacentes aos baluartes
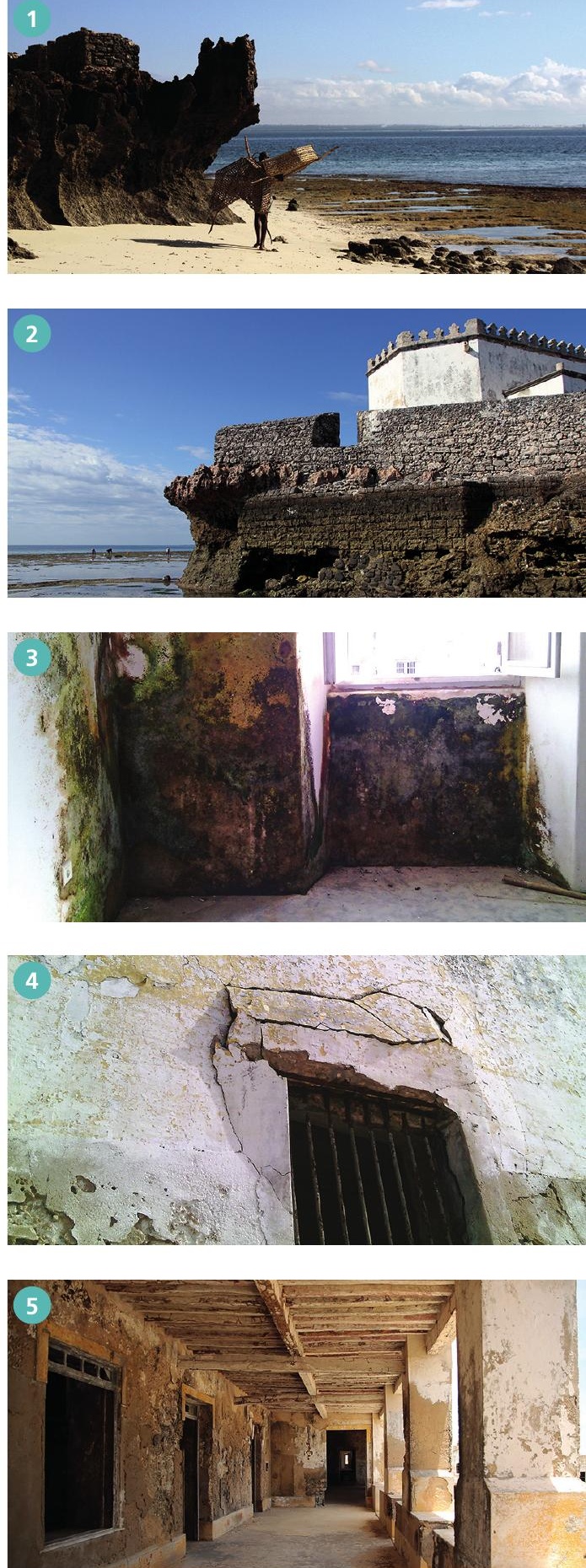

6

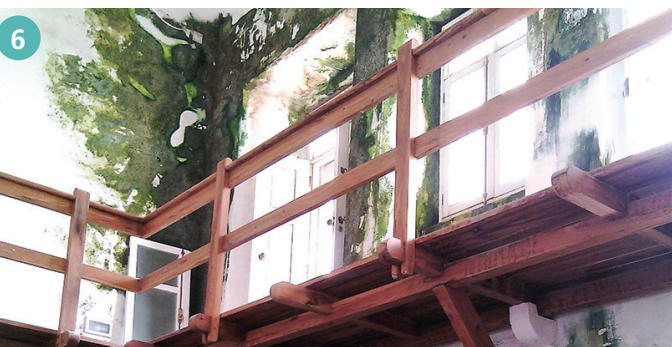




\section{PROPOSTA}

Apresentado e analisado o desafio, poderemos desde logo tirar duas conclusões:

- Que este conjunto de pressupostos permite à Universidade Lúrio gerir o processo inicial de refuncionalização da fortaleza, garantindo um controlo sobre a definição de intervenções futuras, faseadas segundo as suas prioridades institucionais, ao mesmo tempo que promove o desenvolvimento sustentável da construção, economia e emprego locais. Para tal, será crucial que o plano diretor a adotar apresente indicações muito concretas, garantindo um resultado final harmonioso;

- Que, numa segunda fase e para além da universidade, está previsto que outros organismos se instalem neste complexo, conjunto edificado de importância singular na identidade da llha, com grande atratividade para turistas e locais.

A proposta desta oficina concentrou-se, pois, numa tentativa de dar resposta aos diversos pedidos e expectativas de salvaguarda patrimonial, propondo soluções exemplares para uma execução de baixo custo e especialização, sob um ritmo faseado. Nesse sentido, identificados os principais problemas de conservação do edifício e algumas das prioridades de ocupação, foi desenvolvida uma proposta preliminar para um plano diretor de refuncionalização sob gestão direta da UniLúrio.

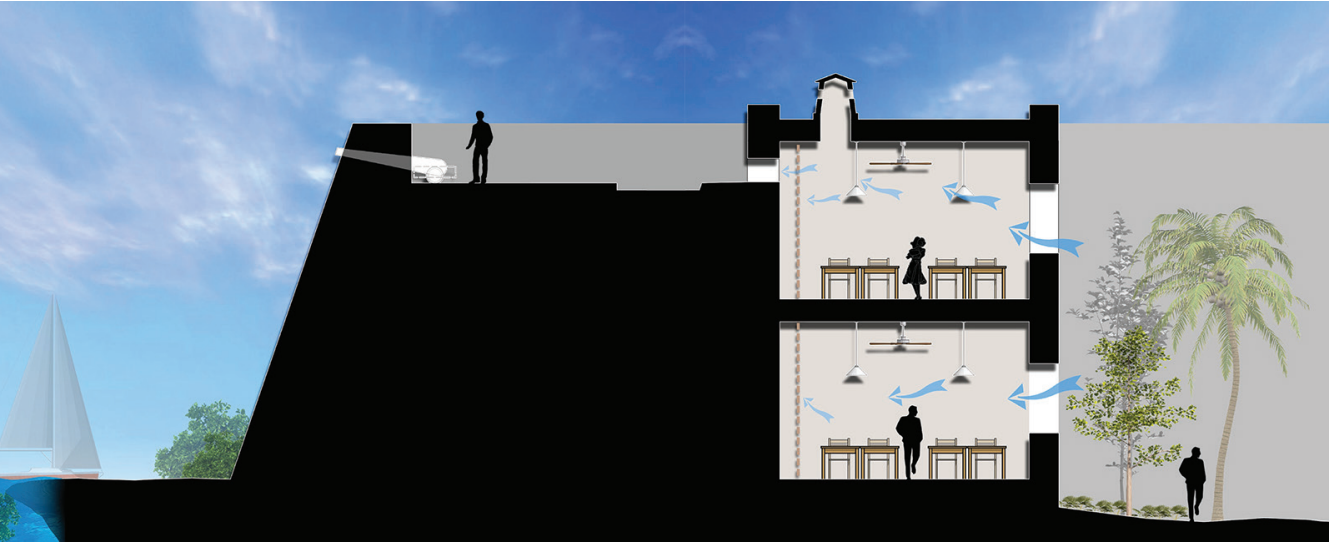




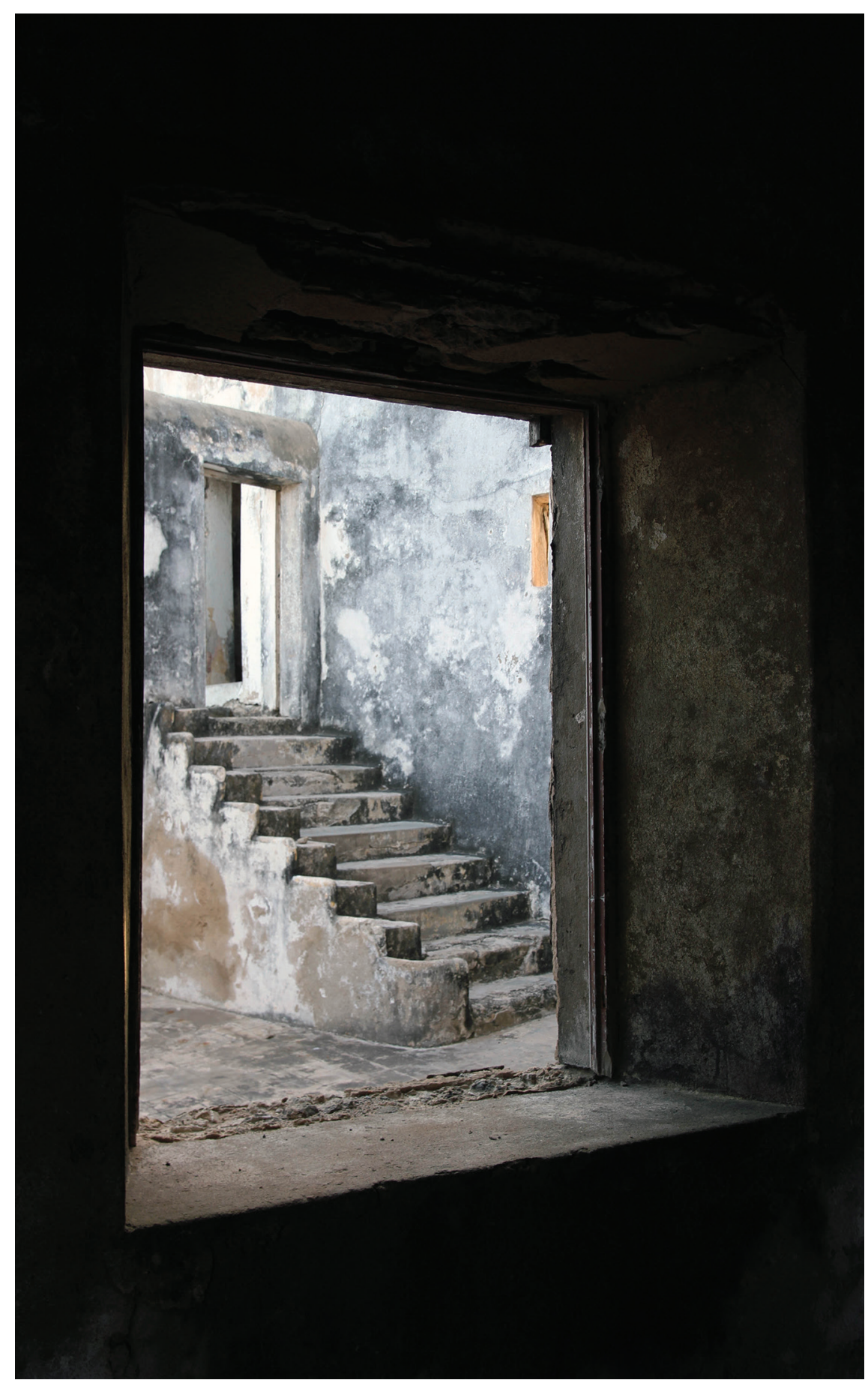




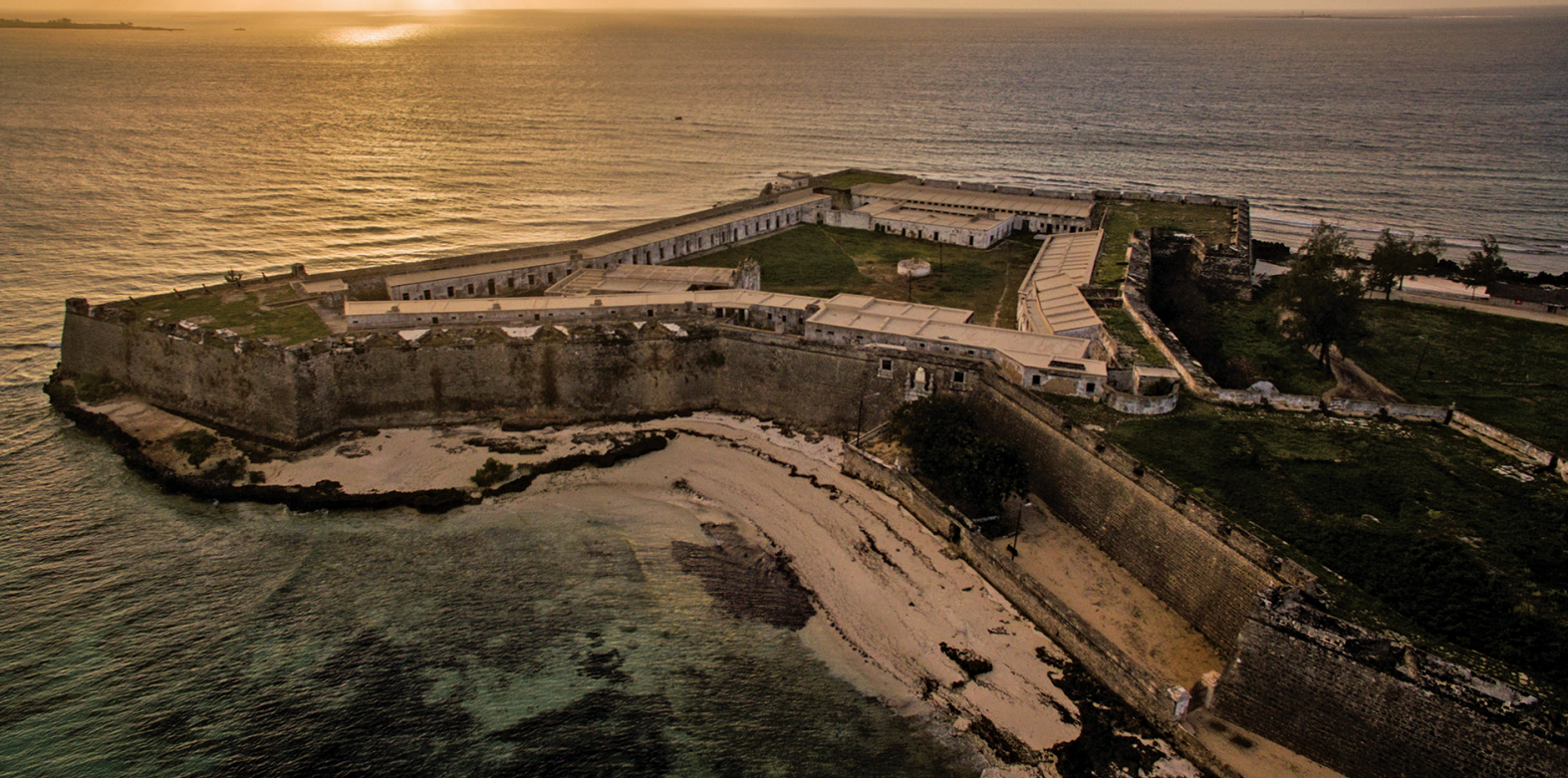

Está prevista uma ocupação inaugural no conjunto edificado da frente oeste. Foram consideradas as estruturas atuais, a necessitar da implementação imediata de trabalhos de acabamentos - pisos, paredes, tetos, portas, janelas, etc. - e de sistemas - água e eletricidade, com respetivos abastecimento, saneamento e drenagem, ligações às redes disponíveis e estudo de alternativas.

Nessa primeira fase de intervenção é proposta a organização do rés do chão de forma a receber pelo menos 10 salas (consoante as necessidades e respetiva adaptação das mesmas) das quais 6 seriam de aulas (com capacidade para acolher até 150 alunos) e as restantes destinadas à direção e apoio, atendimento ao turista e sanitários (já existentes, a precisar de uma reabilitação). No primeiro andar assumindo que poderia corresponder já a uma segunda fase de obras e em simultâneo com o decurso de aulas ao nível térreo - propõe-se a instalação de 10 novas salas de aula, de maior dimensão (com capacidade para acolher até 400 alunos), sala de estudo, reprografia e espaço expositivo (também importante para a distribuição de espaços e circulação dos utentes). Esta ampliação contemplaria a possibilidade de integração de novos cursos. 
No flanco oposto, a leste, encontra-se a principal cisterna da fortaleza. O conjunto de edifícios que a envolve foi escolhido para receber a cantina e respetivas áreas de apoio.

Para além destas duas frentes, está prevista a ocupação da antiga igreja, sendo proposta a sua reconfiguração como auditório, uma espécie de aula-magna, podendo vir a ser usado por outras instituições que se venham a instalar no complexo. As naves laterais serão facilmente convertíveis em áreas de apoio, incluindo a cisterna aí existente.

À frente dessa igreja está o flanco sul da fortaleza, outrora a entrada principal, ultrapassado o fosso que a separava de terra firme. É proposta a sua reabertura (sendo desmontada a cisterna mais recente e já desativada, ali existente) assim como a instalação do CEDIM e uma biblioteca-arquivo da FCSH, que poderiam vir a formar um organismo único. 


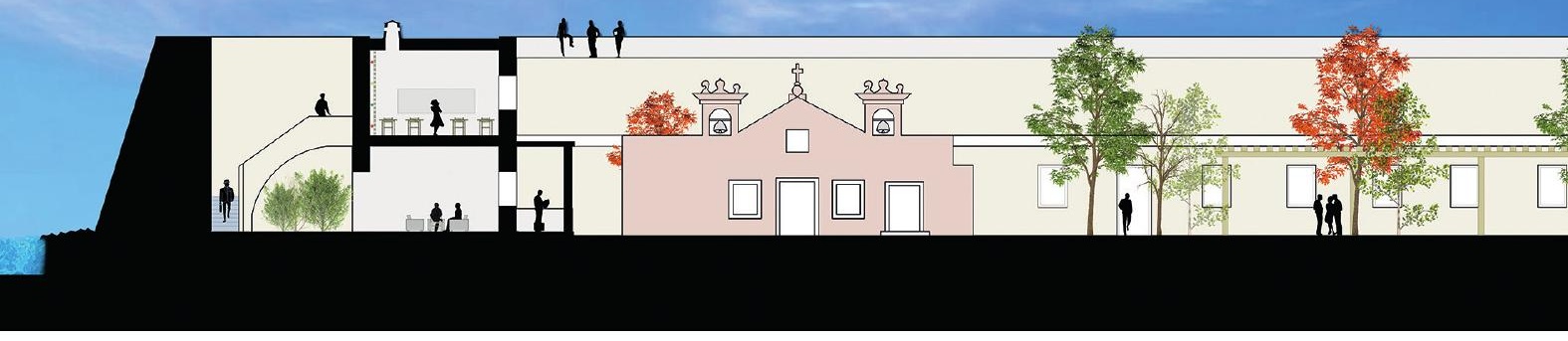

Como resposta aos principais problemas que afetam a conservação das diversas estruturas existentes, foram privilegiadas opções reversíveis, de baixo custo e fácil implementação. Delas são exemplo:

- A fixação de painéis à base de paletes de madeira, suportados por estruturas simples, também de madeira, à parede de alvenaria existente. Esta opção permite a simplificação de montagem/ desmontagem e gestão regular dos sistemas de água, energia e comunicações;

- Potencializar a circulação de ar no interior, reduzindo a temperatura e a concentração de humidade, sobretudo ao nível sensorial, melhorando a sua habitabilidade.

As propostas consideraram a articulação da faculdade com outros organismos, nomeadamente o CEDIM, o GACIM e o potencial Museu Marítimo, revelando- se fundamental a harmonia e bem-estar do e no conjunto. Para isso será ainda decisiva a intervenção de arranjo dos espaços exteriores, designadamente a criação de áreas verdes, percursos e zonas de estar, resultando numa proposta de reconfiguração global do pátio central. O recurso a elementos de construção ligeira (p. e., pérgulas em madeira) privilegiariam dois aspetos:

- A criação de percursos e zonas de estar, podendo ser utilizadas para aula ao ar livre, como esplanada junto à cantina, zonas de lazer, etc.

- A reconfiguração e redimensionamento do pátio central, abrindo-se sobre os flancos (que correspondem aos principais acessos da fortaleza), resguardando-se nos restantes e tornado o espaço exterior mais habitável. 


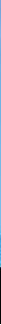

A colocação de vegetação em zonas estratégicas procura contribuir para esta reconfiguração da praça, privilegiando um maior conforto num clima particularmente difícil. A organização das circulações a dois níveis - pátio e caminhos de ronda - é também importante, tanto para os utilizadores assíduos desses espaços, como para os turistas ou habitantes da llha que pretendam fruir da fortaleza.

No curto espaço de tempo em que a oficina se pôde dedicar a este desafio, uma ideia ficou absolutamente clara: a Fortaleza de São Sebastião é o grande símbolo do património edificado da llha e deverá estar de portas abertas à comunidade. Esta proposta pretende contribuir para que tal aconteça.

LEGE N A

ÁREAS VERDES

SALAS DE AULAS - FCSH

DIREÇÃO E APOIO - FCSH

AUDITÓRIO

CEDIM

MUSEU MARITIMO

APOIO AO TURISTTA

PÉRGOLA

CISTERNA

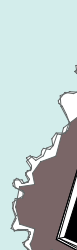

入 


\section{REFERÊNCIAS BIBLIOGRÁFICAS}

BERTI, Maurizio (2014), Conservation of the Fortress of São Sebastião, Ilha de Mozambique. Consultado a 01.05.2017, em: https://www.wmf.org/ blog/conservation-fortress-s\%C3\%A3o-sebasti\%C3\%A3o-ilha-demozambique.

BERTI, Maurizio (2016), Considerações preliminares às obras de restauro e de adaptação necessárias para acomodar a Faculdade de Ciências Sociais e Humanas nos espaços da Fortaleza de São Sebastião na Ilha de Moçambique. Nampula: relatório encomendado pelo Magnifico Reitor da Universidade Lúrio.

ELOUNDOU, Lazare; WEYDT, Jana (2009), Rehabilitation of the Saint Sebastian Fortress, Island of Mozambique. Paris: UNESCO.

FORJAZ, José (2010), Island of Mozambique - Architectural survey and study on local vernacular architecture. Maputo.

GONÇALVES, Nuno Simão (2011), O projecto para a fortaleza da llha de Moçambique atribuído a Miguel de Arruda. Coimbra: Dissertação de Mestrado em Arquitetura, apresentado à Faculdade de Ciências e Tecnologia da Universidade de Coimbra. 

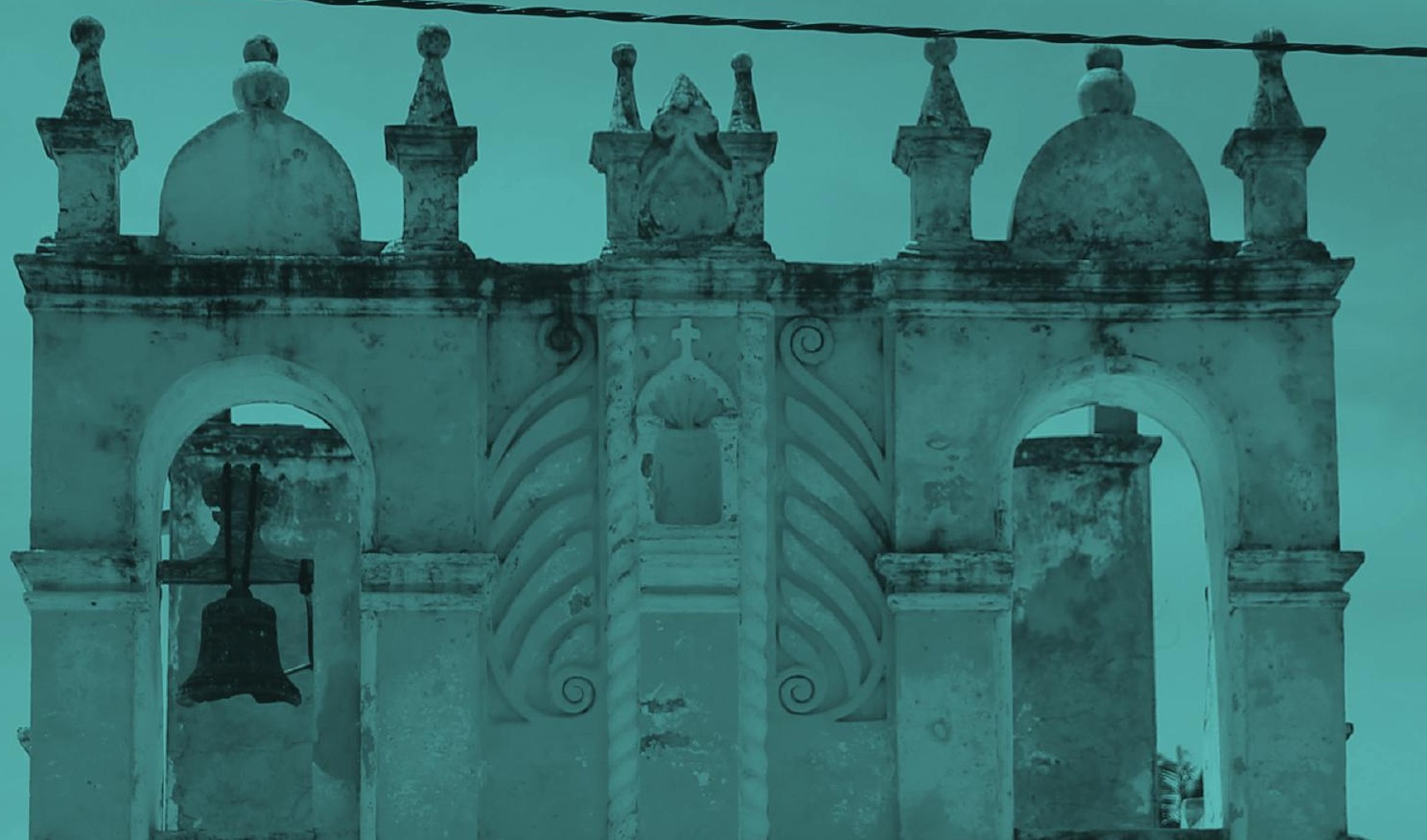

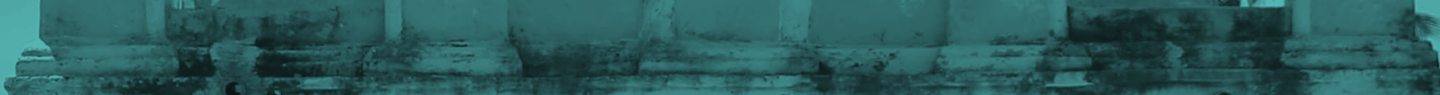

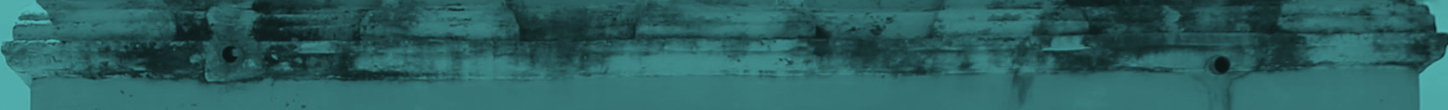
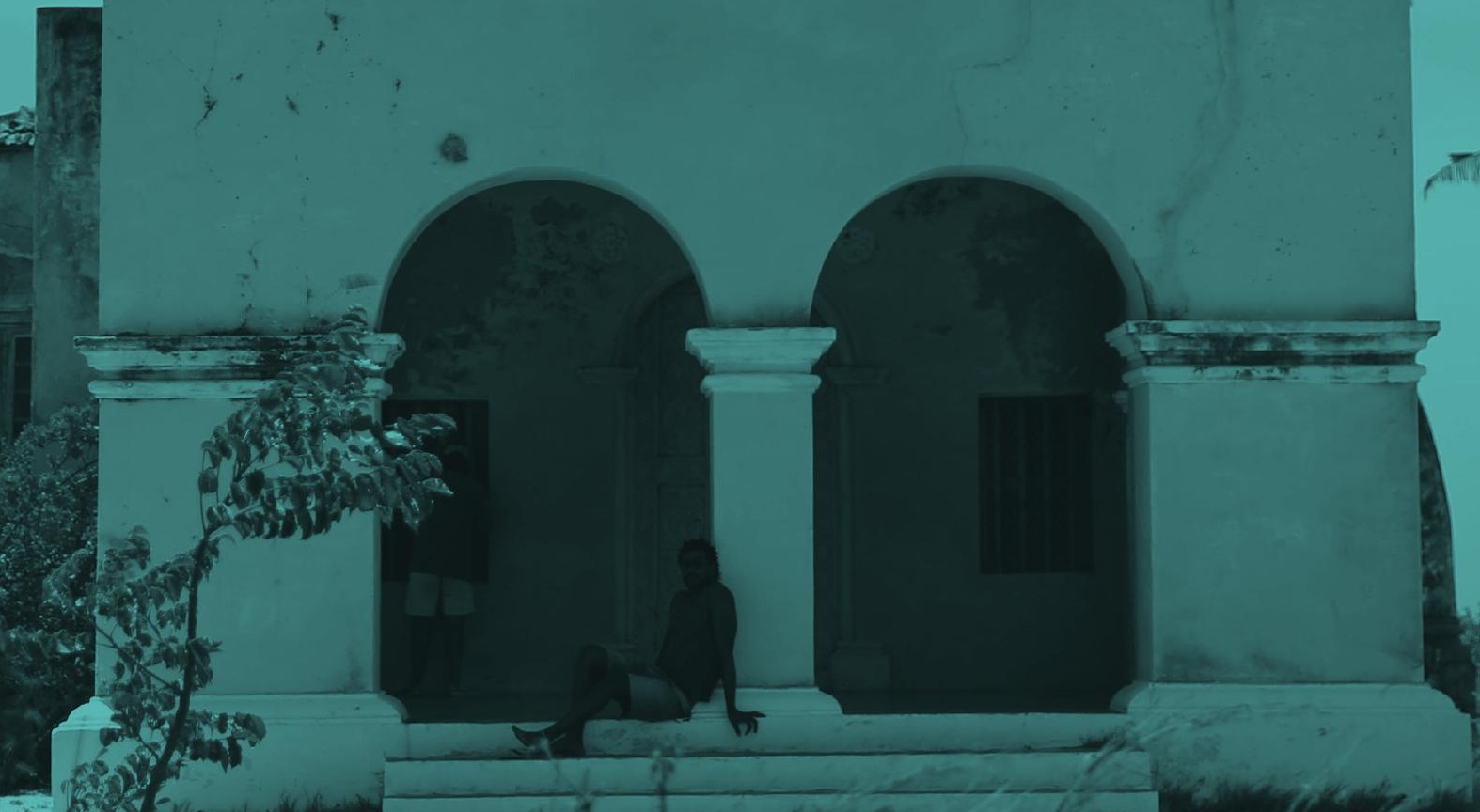

It)

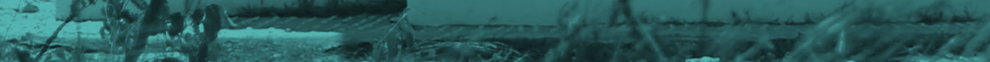

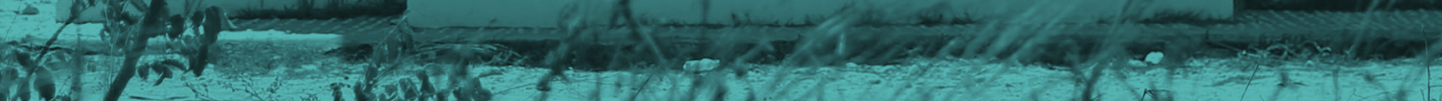

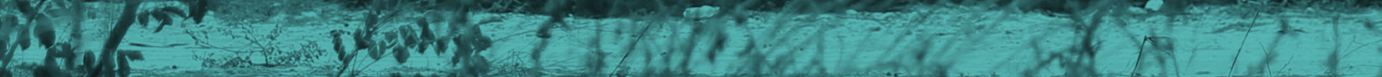
2. 7.

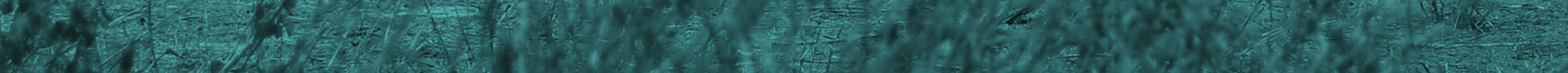




\title{
ILHA DE MOÇAMBIQUE: GERIR $O$ QUÊ E COMO?
}

\author{
Uma leitura do Património \\ Histórico, Cultural e Edificado
}

Jens Hougaard

\section{INTRODUÇÃO}

A pequena ilha, uma barreira de coral levantada do mar numa escala de tempo geológico de milhões de anos, tornou-se o palco de uma história dramática numa outra escala temporal: o da história humana. Protege a Baía de Mossuril do mar bravo e, a partir dela, pode-se controlar a entrada para o ancoradouro na baía. Desde tempos pré-históricos, o protegido ancoradouro, com fácil acesso a água doce e provisão na península de Mossuril, determinou o desenvolvimento da llha como um entreposto no comércio triangular da monção entre a Arábia, a Índia e a África Oriental.

Com a entrada dos Portugueses no Índico, em 1498, a Ilha tornou-se uma paragem obrigatória na rota para a Índia e além. A Baía de Mossuril foi palco de batalhas e a llha a central de comando.

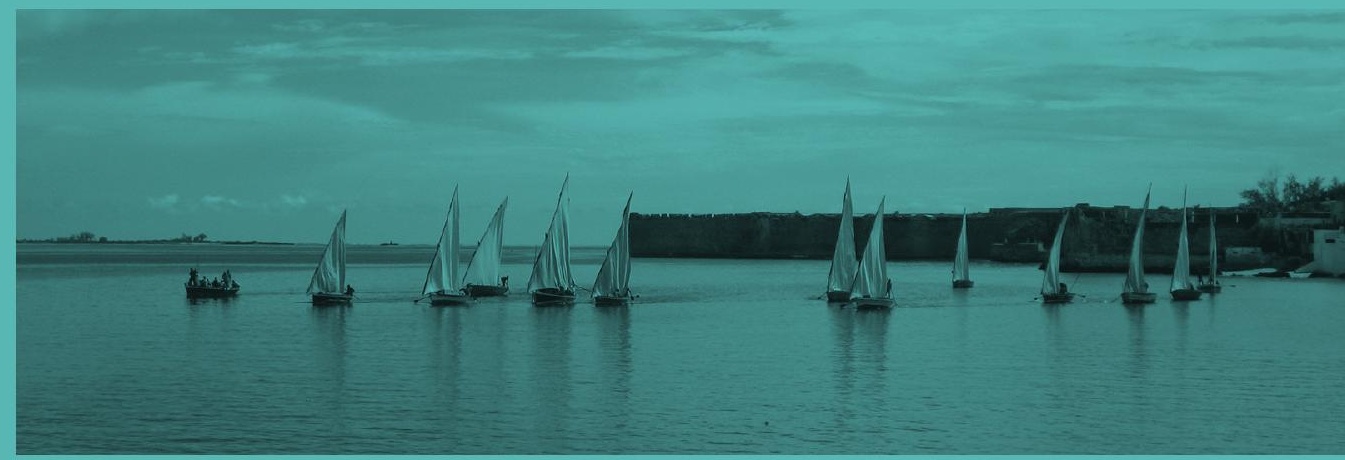


Assim, a llha tinha já a estrutura urbana e as características arquitetónicas que se mantêm, em grande parte, até hoje. Paralelo à segregação urbana, a população muçulmana começou a aderir a confrarias religiosas sob influência do Zanzibar. Uma nova grande mesquita foi construída na margem dos bairros indígenas.

\section{O LUSO-AFRICANISMO}

Numa altura em que a descolonização estava na agenda internacional, Portugal vinculou-se ainda mais às suas colónias. Em fevereiro de 1943, foi constituída a Comissão de Monumentos e Relíquias Históricas de Moçambique [CMRHM], à qual cumpria investigar, classificar, restaurar e conservar os monumentos e relíquias da colónia. Em 1951, o território da colónia, outrora concessionado à administração de diferentes companhias, tornou-se numa única Província de Moçambique, como parte integrada de Portugal.

A teoria luso-tropicalista defendia a mestiçagem de culturas sob o domínio cultural português e foi convenientemente adotada pelo regime português em resposta às emergentes reivindicações de independência das colónias. "Neste contexto, a Ilha de Moçambique representava [...] o paradigma da visão etnocêntrica dessa construção ideológica" (Leite, 2010).

A segregação étnica da população acalmou durante a última década antes da independência e a llha encarou um período curto de revivência como um paraíso tropical turístico, com novos hotéis, piscinas e campos desportivos. Em 1967, foi construída a ponte que liga a Ilha ao continente, permitindo a entrada de veículos. Os habitantes mais velhos da cidade ainda relembram este período como "os bons velhos tempos".

Todos os períodos pré-independentes deixaram camadas e vestígios no meio urbano e na memória dos habitantes que são agora alvo de diferentes interpretações.

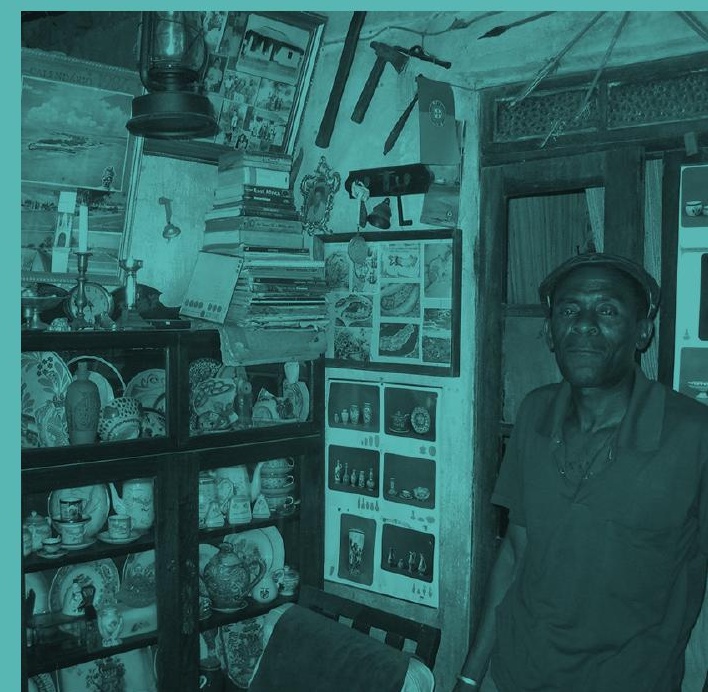


O Ministério de Educação e Cultura criou, em 1977, o Serviço Nacional de Museus e Antiguidades [SNMA] para investigar, divulgar e conservar o património cultural nacional. A brigada de restauro da Ilha deu continuação ao trabalho de manutenção de monumentos já classificados da Ilha. Em 1980, a brigada foi completada por um gabinete de restauro que iniciou estudos históricos urbanos na procura de uma nova interpretação do ambiente urbano.

O gabinete ficou inoperativo em 1985 devido à guerra que assolou o país até 1992. Os resultados das investigações realizadas foram publicados no mesmo ano, num relatório, o chamado Livro Azul, que constituiu a base para a candidatura da inscrição da Ilha na Lista do Património Mundial da UNESCO.

\section{ILHA DE MOÇAMBIQUE - PATRIMÓNIO MUNDIAL}

A llha de Moçambique foi inscrita na Lista do Património Mundial da UNESCO em dezembro de 1991 por recomendação do Conselho Internacional de Monumentos e Sítios [ICOMOS] com base nos critérios IV e VI do Guia Operacional da UNESCO de 1988, a saber:

Critério IV: A cidade e as fortificações na Ilha de Moçambique, e a pequena llha de S. Lourenço, é um exemplo excecional duma arquitetura em qual as tradições locais, a influência portuguesa e, um tanto menos, influências indianas e árabes estão entrançadas.

Critério VI: A Ilha de Moçambique mantém-se como testemunha importante do estabelecimento e desenvolvimento das rotas marítimas entre a Europa ocidental e o subcontinente indiano, a assim a toda a Ásia.

A inscrição ocorreu numa situação de guerra que tinha transformado a Ilha num autêntico campo de deslocados, com um crescimento da população de aproximadamente 7.000 para 17.000 pessoas, grande parte delas alojadas em condições precárias na abandonada cidade de pedra e cal. 


\section{A GESTÃO DO PATRIMÓNIO MUNDIAL}

Em 1992, menos de um ano depois da inscrição da Ilha na lista da UNESCO, foi assinado o Acordo de Paz entre as partes beligerantes. A consequente mudança política para uma economia do mercado e a alienação do imobiliário do Estado, complicou a situação. A Ilha enfrentou um período caracterizado pela degradação contínua e pilhagem do património edificado pela população empobrecida, em simultâneo com uma especulação imobiliária baseada na expectativa do desenvolvimento turístico. Se a llha antes era um barco encalhado, agora era um barco sem leme num mar bravo.

Com a introdução de autarquias, em 1997, a eleição de um novo Conselho Municipal [CMCIM] veio assumir a responsabilidade de gestão das zonas urbanizadas. Preocupada com a situação, a UNESCO elaborou, em 1999, um Programa de Desenvolvimento Humano Sustentável e Conservação Integral da Ilha de Moçambique.

Importará referir que a diferenciação entre a gestão urbana e a gestão do património edificado, sob tutelas diferentes, foi sempre um obstáculo para uma abordagem holística. Um plano integrado não teria viabilidade sem um financiamento externo expressivo.

\section{O PLANO DE AÇÃO}

A contínua degradação levou a uma monitorização proativa da UNESCO, procurando evitar a inclusão da llha na Lista de Património Mundial em Perigo. Em 2006, o Ministério da Educação e Cultura elaborou, finalmente, o Plano de Ação para a Gestão do Património Mundial da Ilha de Moçambique, 2007-2011. Como consequência, foram realizadas ações ao nível legislativo e institucional: 2007, criação do Gabinete de Conservação da Ilha de Moçambique [GACIM], sob a tutela do Ministério da Educação e Cultura; 2009, elaboração do Plano de Desenvolvimento Integrado da Ilha de Moçambique; 2010, elaboração do Plano de Gestão e Conservação 2010-2014, nesta data em processo de revisão.

A criação do GACIM e a contínua monitorização da UNESCO reiteraram a conservação do património edificado como um assunto a levar a sério na gestão urbana da llha. 
A articulação entre o GACIM e o Conselho Municipal nunca foi fácil, mas, apesar das dificuldades de coordenação, a Assembleia Municipal da Ilha de Moçambique aprovou, em 2010, o Código de Posturas Municipais (Resolução n. ${ }^{\circ}$ 22/AMCIM/2010) com posturas específicas sobre a conservação e restauro do património edificado (capítulo VII, arts. 102-112).

O Ministério da Cultura contou, durante anos, com o apoio da Faculdade de Arquitectura e Planeamento Físico da Universidade Eduardo Mondlane [FAPF-UEM], na apreciação de maiores projetos de reabilitação e, finalmente, na elaboração do Regulamento de Proteção do Património Edificado da Ilha de Moçambique, recentemente aprovado pelo Conselho de Ministros.

Continua, contudo, a faltar uma assistência profissional à gestão diária do património no terreno. A criação do Centro de Estudos e Documentação da Ilha de Moçambique [CEDIM] sob a tutela da Faculdade de Arquitectura e Planeamento Físico da UniLúrio [FAPF-UL] (deliberação n. ${ }^{\circ}$ 08/CUN/2011) tinha como um dos objetivos enfrentar esta lacuna. Alguns resultados foram alcançados: em 2014 foi elaborado o Diagnóstico para um Plano de Pormenor da Ilha de Moçambique Insular, numa colaboração entre o CMCIM e a FAPF-UL; um dos temas de tese de licenciatura da FAPF/UniLúrio do ano 2016 foi reordenamento e requalificação das zonas urbanas da entrada e da saída da ponte que liga a Ilha de Moçambique ao continente, sob a forma de um plano de pormenor para estas áreas de transição entre o que é património mundial e o seu subúrbio.

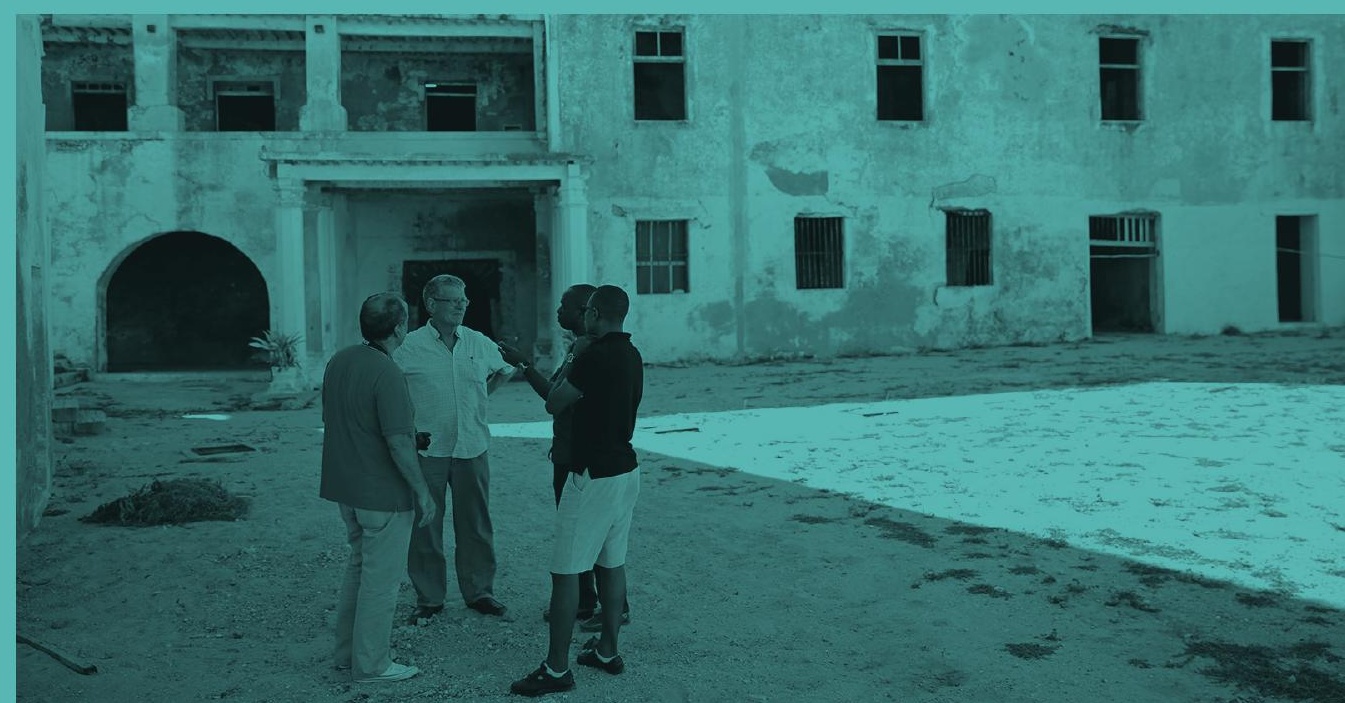




\section{SITUAÇÃO ATUAL}

Durante os últimos anos, a zona insular do município da llha tem visto uma melhoria de infraestruturas e da paisagem urbanas, incluindo a reabilitação de alguns edifícios para fins turísticos. Porém, no processo de requalificação de edifícios para novas funções, alguns perderam a sua autenticidade, fruto de reconstruções e remodelações que alteraram por completo a expressão do edifício. Por outro lado, continua a degradação de muitos edifícios de maior envergadura, sobretudo os que estão à guarda de instituições do Estado.

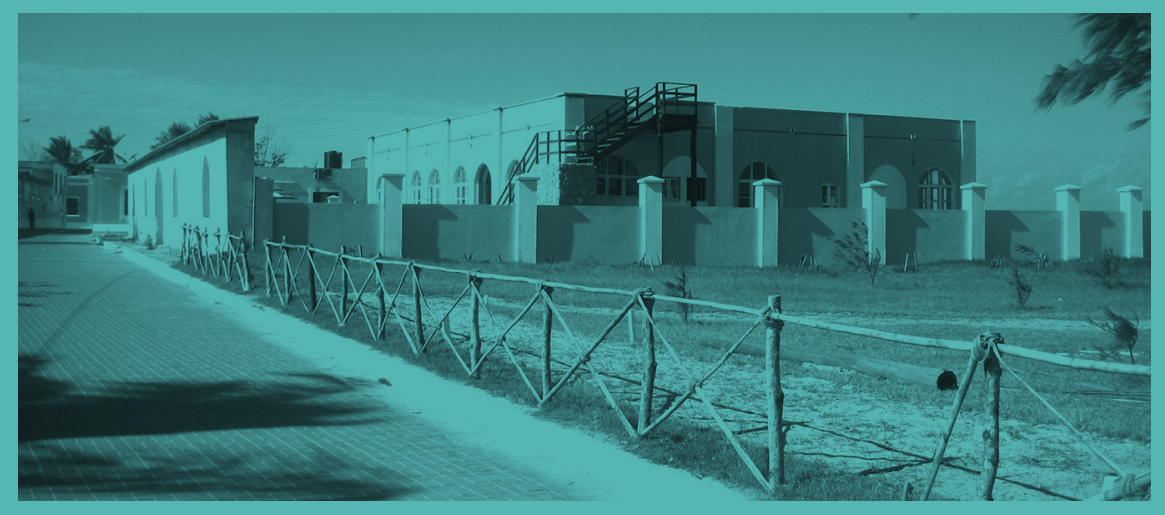

A arborização urbana também tem sofrido uma deterioração devido à falta de poda das árvores de rua e ao excessivo corte das árvores indígenas centenárias, em conjunto com a introdução de espécies alheias ao contexto natural e tradicional.

A juntar a tudo isto, esta zona insular já não constitui uma cidade em si, mas antes a antiga baixa de um município, cuja maior área de desenvolvimento se estende à parte continental.

O município atingiu uma população de quase 50.000 pessoas, das quais a maioria vive em subúrbios desorganizados na parte continental, onde também se desenrola a maior parte das atividades económicas. A preservação do património deve ser vista neste contexto.

A situação da llha continua preocupante. Não existe uma gestão urbana coerente que inclua tanto o planeamento urbano como a conservação do património histórico. Por que é que continua assim? 
1. Uma razão estará na prática de gestão urbana que, na realidade local, vê as leis e regulamentos serem ultrapassados pelos interesses, práticas e costumes locais;

2. Outra razão poderá ser o facto de as ferramentas de gestão do património edificado não estarem estabelecidas ao nível do município: o cadastro municipal continua inexistente e o registo de propriedades não atualizado, sendo o último um resultado da alienação do imobiliário em parcelas autónomas de edifícios sem o devido processo legal completado;

3. Uma terceira razão será a incapacidade técnica, ao nível local, para fiscalizar obras de restauro, de modo a que a reabilitação de edifícios fique ao critério dos investidores;

4. Finalmente, parece claro o desconhecimento e falta de apreciação do valor do conjunto de elementos urbanos e arquitetónicos que concorrem para o valor excecional universal da llha.

Os valores universais excecionais indicados na inscrição da llha na Lista da UNESCO foram formulados numa forma genérica. Na gestão do dia a dia falta identificar as características específicas e os elementos concretos que concorrem para os valores histórico, cultural, social e económico da Ilha e do seu ambiente envolvente.

É neste cenário que a participação da jovem Faculdade de Arquitetura e Planeamento Físico da Universidade Lúrio se inscreve [FAPF-UL].

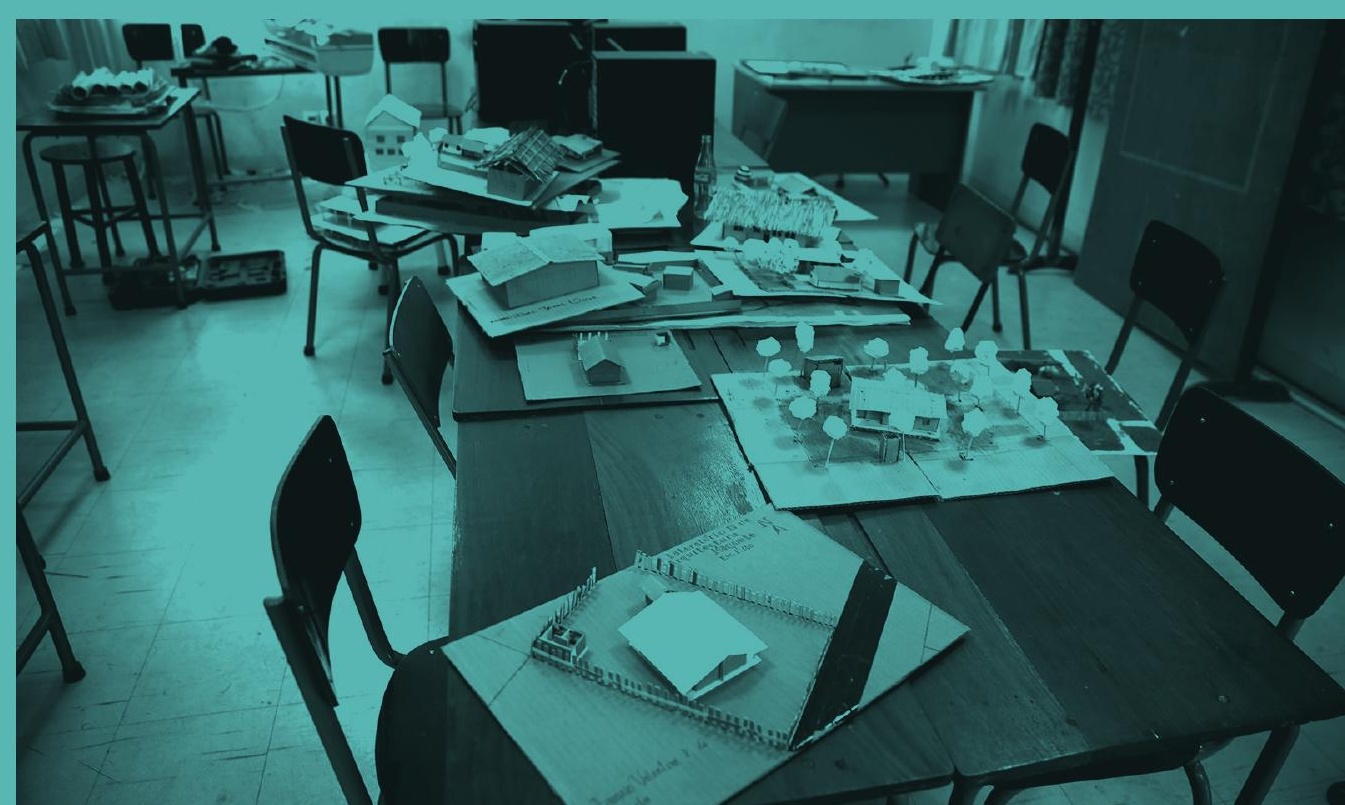




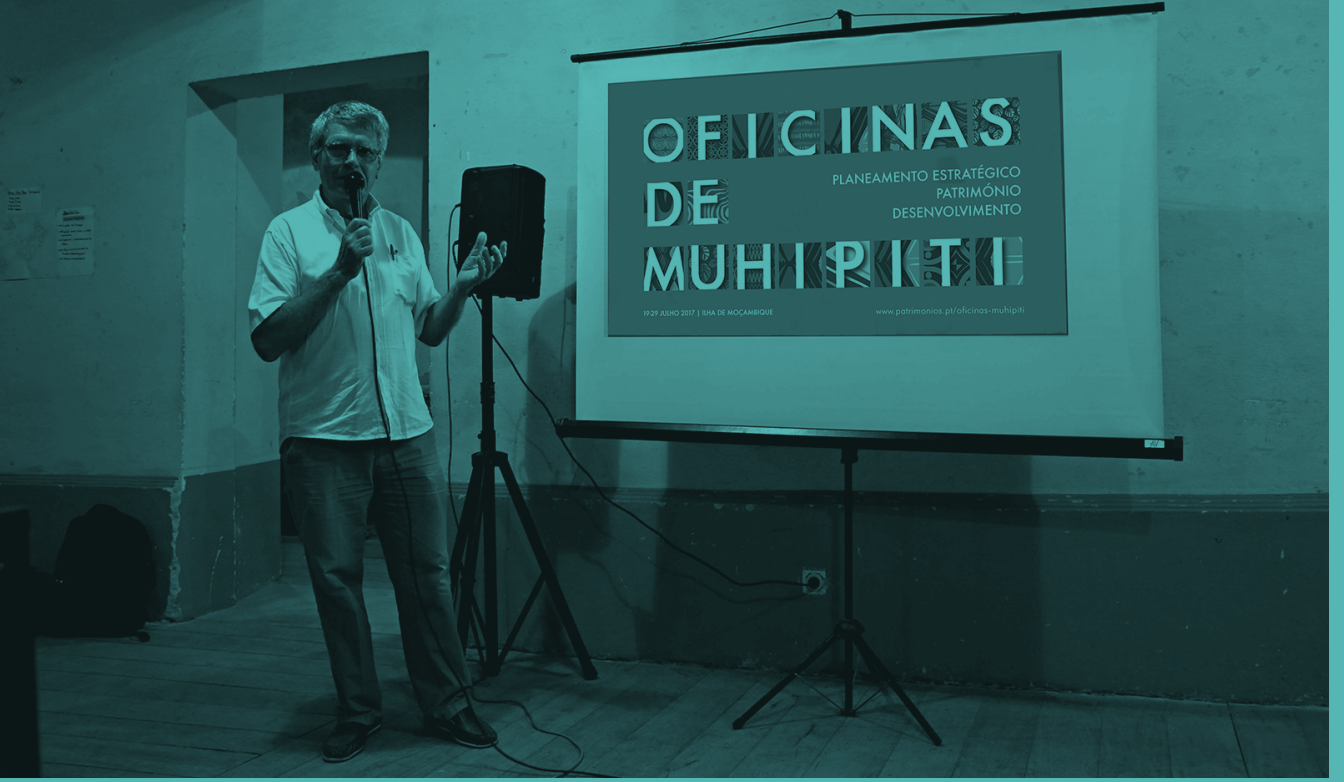

\section{O OFICINAS DE MUHIPITI}

O Oficinas constituiu um passo importante no processo de capacitação da FAPF-UL para cumprir com o seu papel de parceiro profissional na gestão urbana da Ilha. No quadro de cooperação entre as universidades Lúrio e de Coimbra, foram oferecidas a oportunidade de "refletir sobre um modelo de desenvolvimento que permita a salvaguarda integrada e sustentável dos diversos patrimónios da Ilha e também, e essencialmente, uma melhoria das condições de vida da sua população" (Rossa e Alcolete, 2017).

Mas a cooperação entre as duas universidades também deve ser vista num contexto mais amplo. Há um crescente interesse pela Ilha por parte de instituições científicas e educacionais internacionais, que se materializa em pesquisas temáticas por elas desencadeadas. Os temas de destaque nos últimos anos têm sido: o comércio de escravos; arqueologia marinha; história e cultura Suaíli; diáspora emakhuwa; meio ambiente marinho, entre outras. Alguns parceiros recentes nestas investigações são: NIREMA/PUC-Rio, Brasil; Smithsonian National Museum of African American History \& Culture, EUA; Universidade de Roskilde, Dinamarca; Universidade de Witwatersrand, Joanesburgo, África do Sul; Universidade de Washington, Seattle, EUA; Instituto Chr. Michelsen e a Universidade de Bergen, Noruega; Departamento de Assuntos Culturais do Oceano Índico e a Secção da Escola Nacional de Arquitetura de Montpellier, França. Uma colaboração entre os parceiros científicos seria desejável. 


\section{ALGUMAS RECOMENDAÇÕES}

A minha palestra no Oficinas foi uma tentativa de catalogar os elementos e características da Ilha que suportam o valor excecional universal, e de avaliar as respostas dadas em termos de políticas, regulamentos e gestão concreta.

A catalogação não pretendia dar resposta objetiva a cada situação. Foi apenas uma chamada de atenção à enorme quantidade de pormenores que, em conjunto, constituem o património da llha, mas que muitas vezes são eliminados ou adulterados por ignorância.

Esta catalogação não ficou completa, limitando-se a alguns exemplos que sirvam como inspiração para o trabalho contínuo de identificação, publicação e gestão das qualidades do ambiente urbano da Ilha.

As disciplinas consideradas no catálogo foram:

1. Formação Geológica e Topográfica

2. Flora e Fauna

3. História

4. Cultura, Vida Social e Económica

5. Política, Regulamentação e Prática da Gestão Urbana e Patrimonial

A classificação usada no catálogo foi:

a. Camadas (cronologias, hierarquias e estratos);

b. Vestígios (relíquias, sinais e indicadores);

c. Memórias (documentação, lembrança, tradição oral e conhecimentos tradicionais);

d. Interpretações (sentimentos, opiniões e interesses).

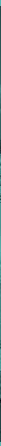




\section{Formação Geológica e Topográfica}

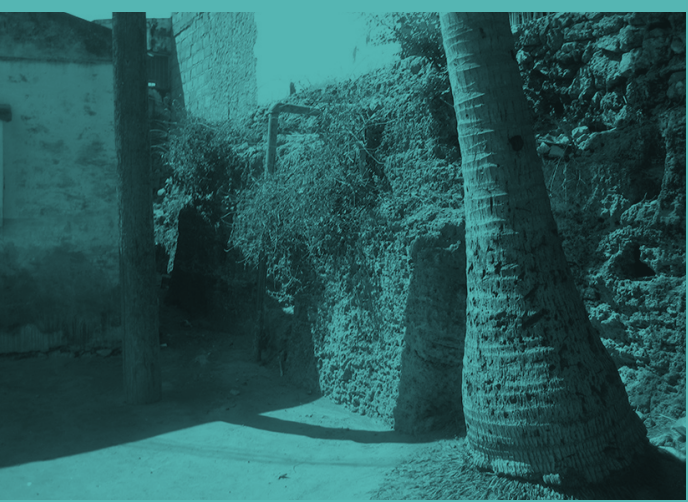

a. Camadas: a História da Terra está escrita nas rochas. É necessário identificar a cronologia das formações primárias e secundárias e a topografia resultante de atividades humanas em diferentes períodos;

b. Vestígios: formações resultantes do desenvolvimento geológico e das intervenções do Homem nas costas, nas pedreiras na ponta da Ilha e nas ruas terraplenadas;

c. Memórias: escondidas nos vestígios físicos, nas lendas, na toponímia tradicional e reveladas em estudos científicos;

d. Interpretações: são dirigidas por interesses científicos, estéticos, comerciais ou de culto.

\section{Flora e Fauna}

a. Camadas: espécies bravas e cultivadas (proveitosas, decorativas ou daninhas);

b. Vestígios: que existem ou existiram na llha;

c. Memórias: conhecimento da origem, do uso tradicional e do tratamento adequado;

d. Interpretações: interesse de proveito, simbólico, estético e comercial. 


\section{História}

a.Camadas: desenvolvimento histórico urbano por fases históricas;

b. Vestígios: estrutura urbana e características arquitetónicas; memoriais, cemitérios, fragmentos arqueológicos, documentos e narrações;

c. Memórias: guardadas de diferentes modos (memória pessoal ou transmitida pelos mais velhos, guardada em documentos ou escondida em vestígios);

d. Interpretações: muitas interpretações disputam a importância histórica da cidade (símbolo nacional; centro religioso; sítio de recreio e de oportunidades comerciais (turismo); testemunho da cultura swahili, das influências culturais portuguesa e indiana, da mestiçagem de culturas e do comércio de escravos).

\section{Cultura, Vida Social e Económica}

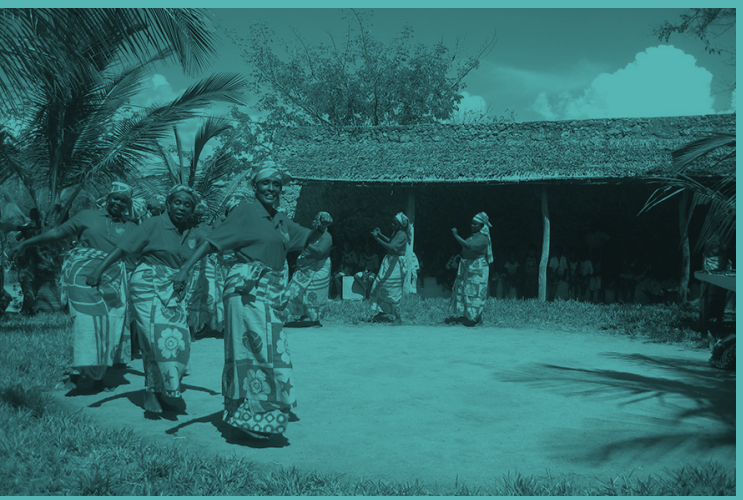

a. Camadas: a Ilha mantém uma diversidade cultural que partilha o mesmo espaço. Está estratificada em grupos e camadas culturais, sociais e económicas entrelaçadas numa complexa simbiose; 
b. Vestígios: manifestações culturais e sociais, crenças, cultos, festas, cantos e danças, ofícios tradicionais e comércio;

c. Memórias: estão guardadas em usos e costumes, tradição oral, conhecimentos de técnicas profissionais herdadas. A memória está em perigo sob as influências cultural e comercial exteriores. Ainda existe, mas está fragmentada e a perder-se;

d. Interpretações: dependem da origem e interesse da pessoa (interpretações de descendentes da população da cidade colonial, dos bairros indígenas ou de origem rural; dos investigadores científicos ou dos investidores).

\section{Política, Regulamentação e Práticada Gestão Urbana e Patrimonial}

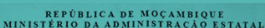

MAPA DA CIDADE DE ILAA DE MOCAMBIOCE

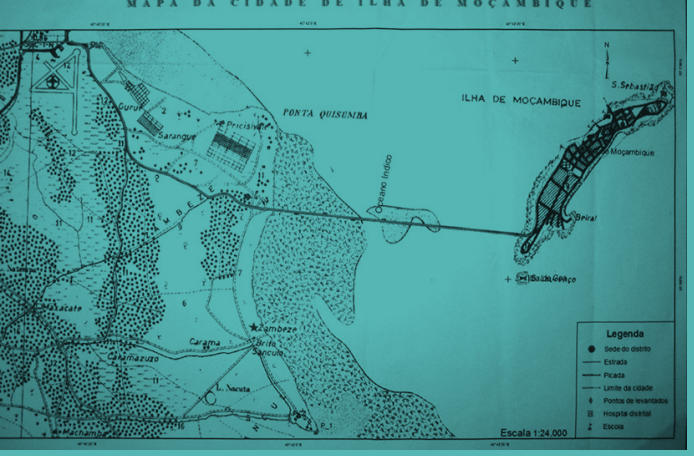

a. Camadas: políticas legislativas e regulativas formam uma construção em que as convenções internacionais assinadas pelo governo constituem o fundamento. A legislação nacional orienta e os regulamentos distritais e municipais regularizam a execução. Verifica-se que a gestão urbana está em grande parte influenciada pelas práticas e costumes locais e interesses económicos de grupos e pessoas influentes;

b. Vestígios: intervenções urbanas e projetos realizados em conformidade ou não com leis e regulamentos;

c. Memórias: conhecimentos ou não sobre o quadro legal que orientaria a gestão urbana;

d. Interpretações: valorização ou não do quadro legislativo pelos diferentes intervenientes na gestão urbana. 


\section{POST SCRIPTUM}

O Património Histórico e Cultural da Ilha de Moçambique está em declínio, não só pela subida do mar, mas sobretudo pela ação do homem. Será tarde. É minha esperança que o trabalho iniciado no Oficinas continue em prol duma formação profissional de jovens moçambicanos para que saibam interpretar, valorizar e conservar as camadas, os vestígios e as memórias da história e cultura da llha.

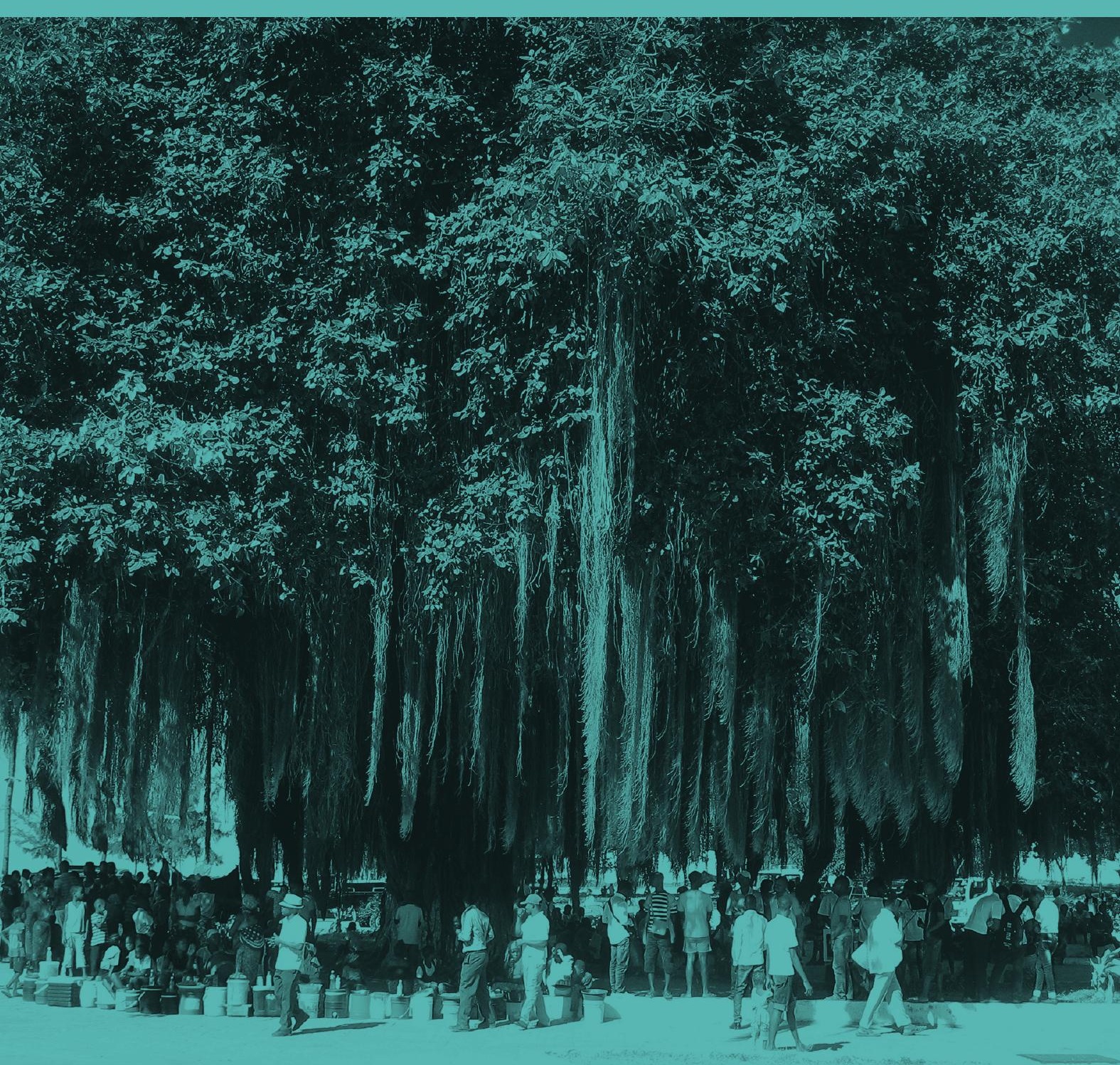




\section{REFERÊNCIAS BIBLIOGRÁFICAS}

Conselho Municipal da Cidade da Ilha de Moçambique (2010), Código de Posturas Municipais (Resolução n. ${ }^{\circ} 22 / A M C I M / 2010$ ).

Decreto n. ${ }^{\circ}$ 28/2006 de 13 de julho (cria o Gabinete de Conservação da Ilha de Moçambique e aprova o respetivo Estatuto Orgânico).

Decreto n. ${ }^{\circ}$ 54/2016, de 28 de novembro (aprova o Regulamento sobre a Classificação e Gestão do Património Edificado e Paisagístico da llha de Moçambique. Boletim da República n. ${ }^{\circ} 142$ (I)).

LEITE, Pedro Pereira (2010), Casa Muss-amb-ike: O Compromisso no Processo Museológico. Dissertação de doutoramento em museologia, apresentada à Universidade Lusófona de Humanidade e Tecnologias.

Ministério da Educação e Cultura/ Direcção Nacional de Património Cultural (2006), Plano de Ação para a Gestão do Património Mundial da Ilha de Moçambique, 2007-2011. Maputo: Ministério da Educação e Cultura e DNPC.

ROSSA, Walter; ALCOLETE Isequiel (coords.) (2017), Oficinas de Muhipiti: planeamento estratégico, património, desenvolvimento, relatório pósevento. Ilha de Moçambique: universidades Lúrio e de Coimbra.

Secretaria de Estado da Cultura de Moçambique; Arkitektskolen i Ãrhus, Danmark (1986), Ilha de Moçambique, relatório - Report 198285. Moçambique e Dinamarca: Secretaria de Estado da Cultura e Arkitektskolen i Ãrhus.

UNESCO (1988), Operational guidelines for the implementation of the World Heritage Convention. Paris: UNESCO World Heritage Centre.

UNESCO (1999), Programa de Desenvolvimento Humano Sustentável e Conservação Integral da Ilha de Moçambique. Paris: UNESCO World Heritage Centre.

Universidade Lúrio (2010), Plano Estratégico 2010-2014. Nampula: Gabinete de Planificação da Unilúrio. 


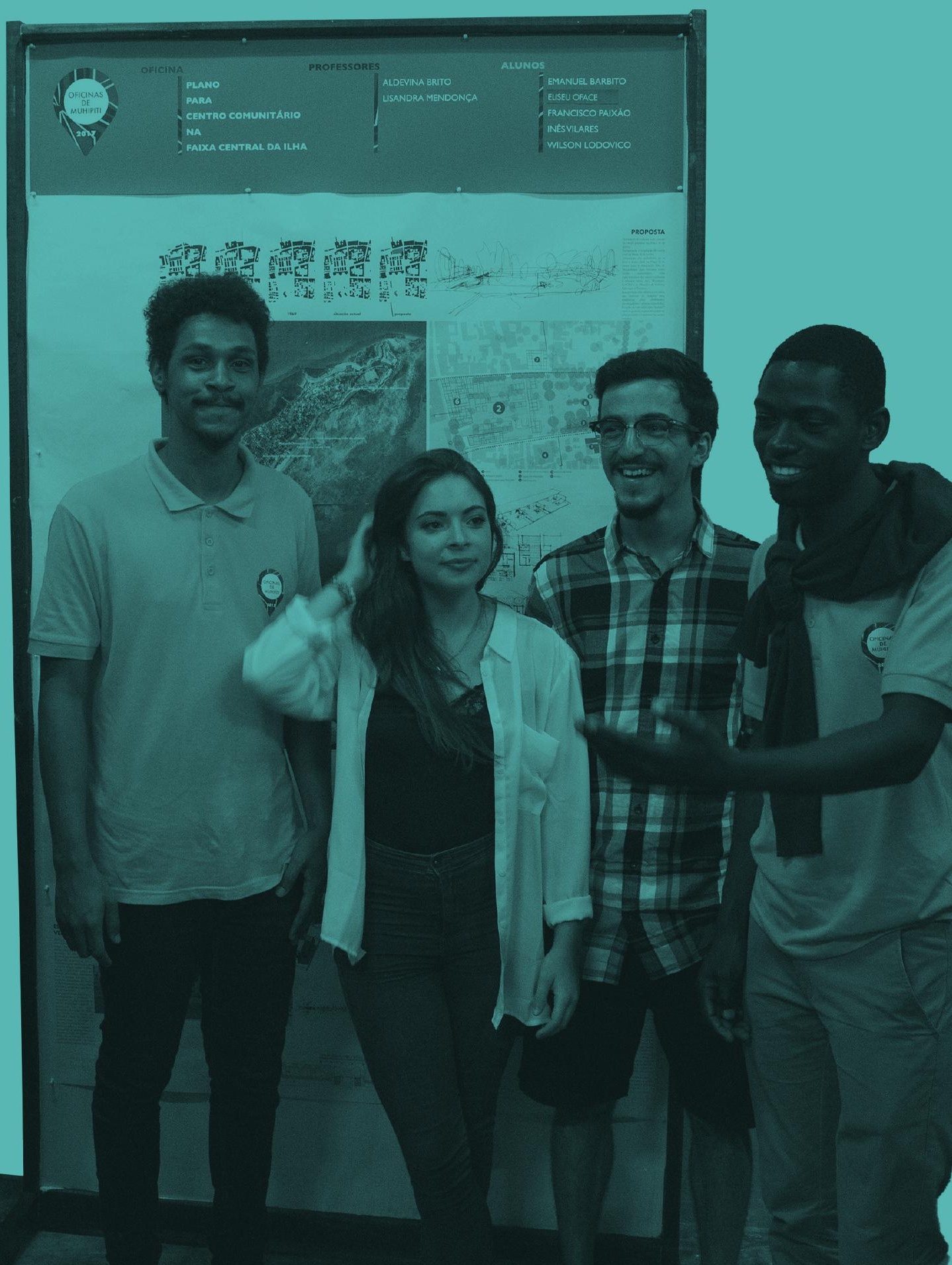




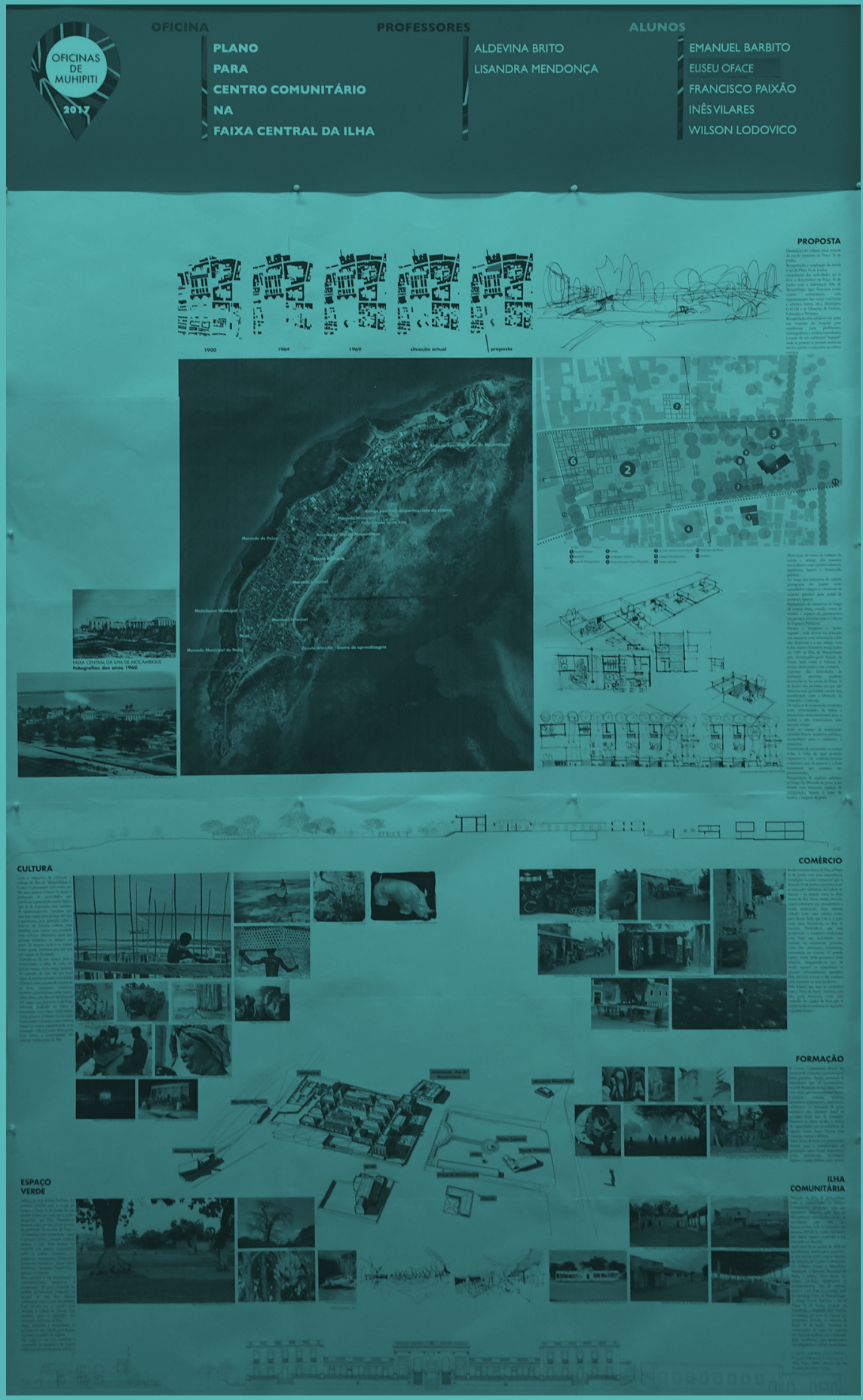




\title{
PLANO PARA CENTRO COMUNITÁRIO NA FAIXA CENTRAL DA ILHA
}

\author{
Aldevina Brito \\ Lisandra Franco de Mendonça
}

\section{Missão-encomenda previamente formulada}

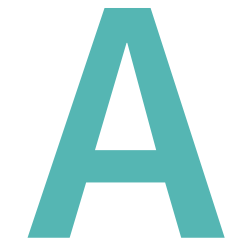

faixa situada sensivelmente no centro da llha, definida no sentido norte sul pela extensão do edifício do hospital e compreendida no sentido este-oeste entre ambas as costas, marca a articulação entre a dita cidade de pedra e cal e o bairro de macuti. É hoje um emaranhado de ruínas, espaços residuais e informalmente apropriados públicos e privados, edifícios desaproveitados de grande potencial (a começar pelo do Hospital), mas também um espaço de reunião e encontro da comunidade local, uma espécie de fórum que carece de clarificação de usos e espaços. Pretende-se que esta oficina faça um levantamento circunstanciado de toda essa complexa realidade e proponha um ou mais cenários de reurbanização do conjunto e reabilitação das suas construções e espaços por forma a que esse caráter de centro cívico surja de forma clara. 
Nos alvores da Guerra Colonial/de Libertação (1964-1974), o governo central mandou edificar, por entre a vegetação densa do antigo jardim e viveiro do Largo Afonso de Albuquerque, um pequeno edifício térreo de duas águas, com alpendre de acesso disposto a norte, afeto à escola primária para raparigas. A reprodução deste tipo de escolas, a partir de meados da década de 1950, procurava reformular a abrangência do ensino nas várias cidades da província. O seu desenho assentava na resolução dos problemas de adaptação climática dos edifícios, da expressão modular dos elementos estruturais e dos sistemas construtivos, apresentando, no geral, algumas características constantes, nomeadamente a implantação, alheia à orientação do tecido urbano e aos "limites do terreno orientando-se antes segundo os pontos cardeais" (Miranda, 2013: 236).

No centro do largo foi erigido (c. 1966) um monólito irregular de pedra, do escultor Helder Batista (1932-2015), com a efígie de Luís de Camões e uma dedicatória ao IV centenário da estadia do poeta na Ilha (14691969) na face longa virada para o oceano, e um soneto de Os Lusíadas, no lado curto virado a nordeste. O memorial, renomeado localmente Pedra Sagrada ou Monumento Afonso de Albuquerque e a escola primária, foram algumas das muitas obras inauguradas, em 1969, na Ilha e continente fronteiro, pelo governador-geral Baltazar Rebelo de Sousa, por ocasião das Comemorações dos Centenários (ARPAC, Cx. Nampula, XI, Monumentos e Locais Históricos, 4).

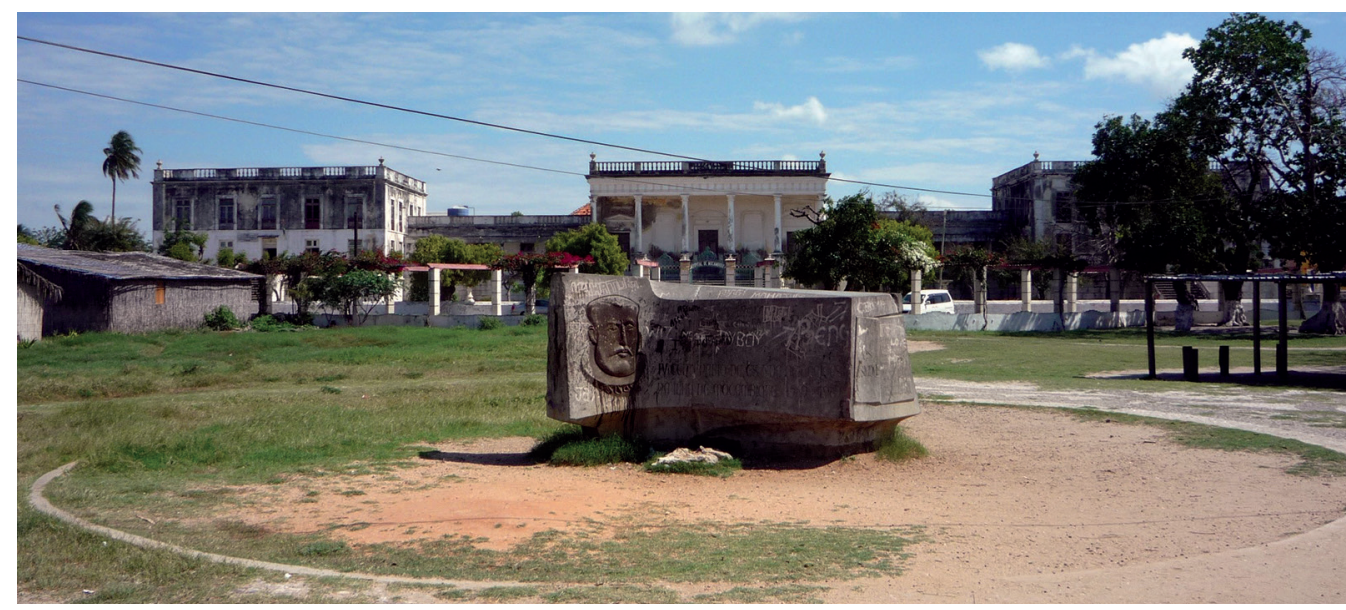




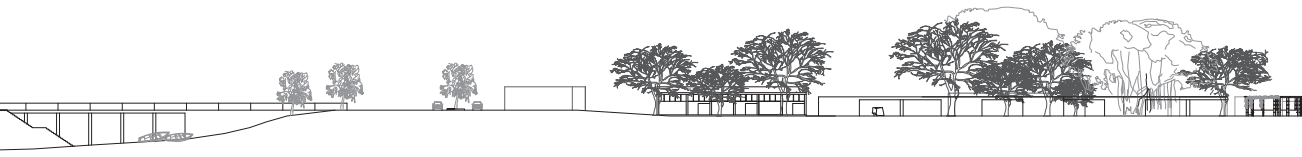

Com a Independência, a escola, renomeada 16 de Junho, recebeu um segundo volume isolado e símile ao primeiro, de construção mais modesta, e a área em torno foi amurada. Já antes, o muro de contenção e a subida de cotas na frente marítima a este, para contrapor o desgaste provocado pela violência das marés, alterara definitivamente a relação visual entre o antigo largo (abaixo do nível do mar) e a linha de água. Desapareciam também grande parte das casuarinas usadas para fixar as dunas nesse lado da costa.
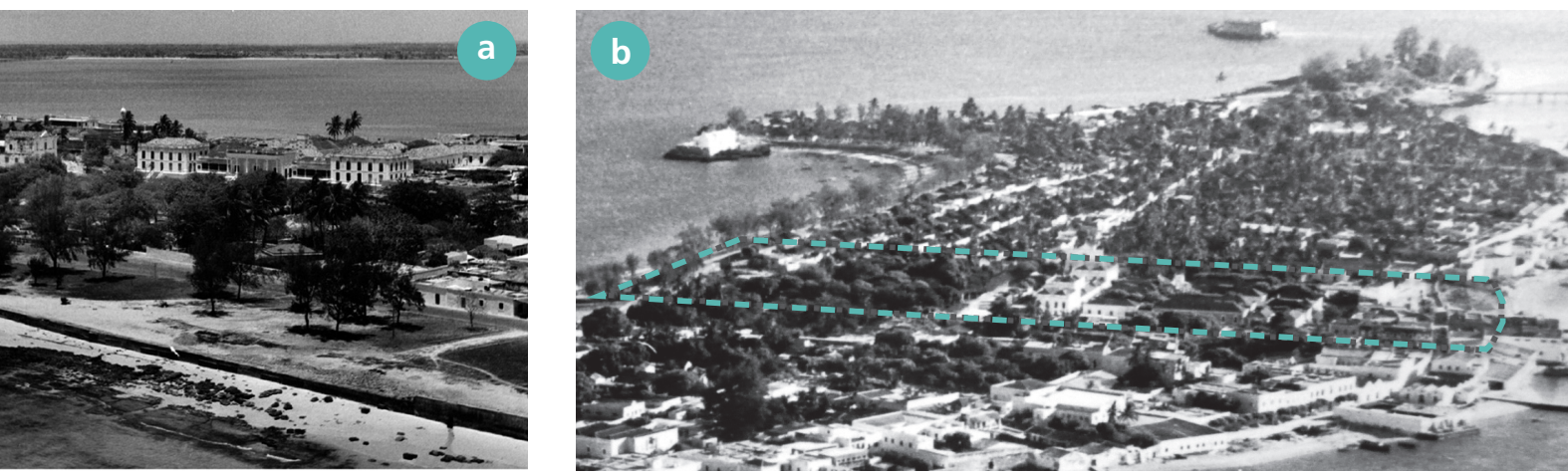

Excerto de fotografias aéreas da Ilha de Moçambique, 1974:

a) área do Hospital de Moçambique e do Largo Afonso de Albuquerque;

b) área de estudo.
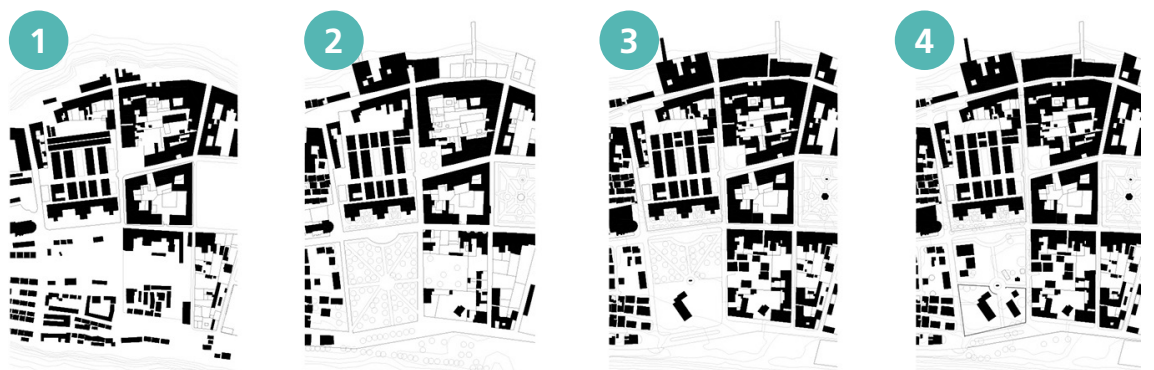

Representação esquemática da evolução da ocupação na área de estudo:

1) final do século $X I X$;

2) meados do século $X X$;

3) final da década de 1960;

4) situação atual. 


\section{O CENTRO COMUNITÁRIO}

O estudo desta oficina teve por base o trabalho de campo e a pesquisa histórico-social efetuada previamente e no local. Realizaram-se entrevistas a cabeças de família dos vários bairros da cidade de macuti e a alguns líderes espirituais da comunidade, sobre a pertinência de vários elementos dispersos existentes na área de intervenção e suas imediações (i. e., a Escola Primária 16 de Junho; o poço confinado ao logradouro de um restaurante da Praça 16 de Junho e que outrora abastecia o jardimviveiro; vários locais de culto, nomeadamente a Mesquita Grande e a das Palmeiras e a Igreja de Nossa Senhora da Saúde), possibilidades de requalificação dos espaços e aspirações urbanas dos habitantes.

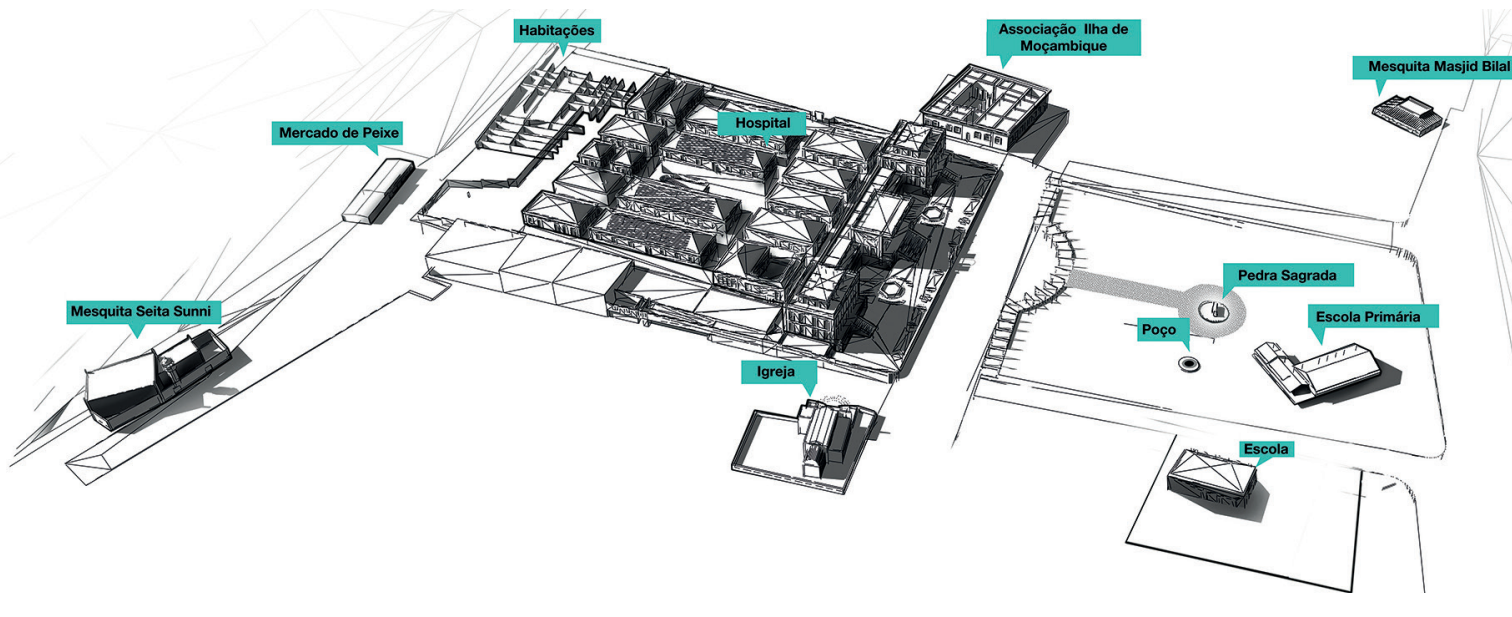

Apesar de a discussão ter privilegiado, inicialmente, o aproveitamento de alguns pavilhões desocupados do hospital para outras funções com o serviço relegado atualmente ao nível de centro de saúde —, no seguimento dos trabalhos, e de acordo com informações recebidas, esse estudo foi abandonado. Averiguou-se que o hospital, a carecer de obras urgentes, foi objeto de um projeto de reabilitação, a cargo do Ministério da Saúde, e que a execução faseada das obras, iniciada recentemente, abrangerá o inteiro complexo. Restou-nos extrapolar que a refuncionalização parcial daquele equipamento para a instalação, por exemplo, de uma instituição académica - a conformação e a situação 
de cal, sobrelevado por meio de um embasamento, tem a composição e tecnologia típicas das casas de influência indo-portuguesa comuns na Ilha: linhas simples numa planta retangular composta por várias dependências que constituíam os quartos de dormir e salas de estar e comer, e uma zona de serviço (com sanitários, cozinha e cisternas) no tardoz, numa cerca de tipo pátio. A entrada principal, sobre a Avenida dos Heróis, faz-se através de um alpendre do tipo colunata e colunas de alvenaria com arestas vivas formando uma varanda larga, onde se apoia a escada de amplos corrimãos.

Para além da pertinência do programa desta associação, as obras em curso no edifício-sede permitiram à oficina apreciar técnicas de construção tradicionais em risco de caírem em desuso. No estaleiro, foram construídos dois tanques de queima de cal para a preparação tradicional de cal apagada/hidratada a utilizar nas argamassas e rebocos da obra; a cobertura do edifício foi refeita repondo a estrutura de troncos encastoados na espessura das paredes-mestras colocados no sentido de menor vão, sobrepostos por uma espécie de esteira de varas mais delgadas, onde se assenta areão grosso e argamassa de cal, terra arenosa e, por último, betonilha de cal e areia misturada com óleo de murrapa. Para além destes trabalhos, os de marceneiro e ebanista no mobiliário do edifício, têm sido executados com primor por membros da associação.

O domínio das tecnologias construtivas ancestrais e a resiliência destas artes são um património vivo de Moçambique. O conhecimento históricocrítico desse património permite-nos enfatizar que essas práticas se traduziram na llha como provavelmente em nenhum outro local de Moçambique, na "mais completa síntese de culturas arquitecturais [...], no que traduz com exactidão e complexidade, sedimentação e síntese das suas estruturas sociais" (apud Fonseca, 1968: 48).

Além deste novo equipamento cultural situado às portas da Praça 16 de Junho, advinha-se a abertura do Centro de aprendizagem Ozuela Wixutta, idealizado e financiado por um privado, no Bairro de Santo António. Organizado em duas casas de macuti interligadas por pequenos pátios, esse espaço multiusos tem o foco nas mães do bairro e nos jovens, maioritariamente sem ocupação. O centro ministrará cursos de culinária, cerâmica, pintura, costura, etc., conciliando espetáculos de música, dança e teatro. 
Ao longo do limite sul da praça, esboçou-se um edifício térreo sob uma longa pala, esplanadas e vários atravessamentos, para instalar os restaurantes que ali se encontram e alguns serviços de apoio (sanitários públicos, quiosque, armazém e casa do jardineiro). Propôs-se a demolição do volume mais recente da Escola Primária 16 de Junho (transferindo essa função para o edifício da antiga escola primária situado nas imediações da praça, a sul, devidamente reabilitado e ampliado) e do muro de vedação. Ensaiou-se, nessa área, a reposição das árvores e o aproveitamento da subida suave de cotas em direção à costa este para a criação de uma espécie de anfiteatro natural, onde a população possa assistir, sentada na relva, a eventos de carácter efémero, como cinema ao ar livre, reuniões comunitárias, entre outros.

A proposta de repor as espécies arbóreas e a vegetação densa da praça abrange as ruas adjacentes, nomeadamente os carreiros de casuarinas ao longo do arruamento e das dunas da costa a este. A plantação de árvores deve seguir uma investigação sobre as espécies existentes em cada local e sua antiga proveniência (estas marcavam distintamente a paisagem, tendo os habitantes referido espécies e proveniências várias do Índico), a registar nos vários locais com sinalética própria.

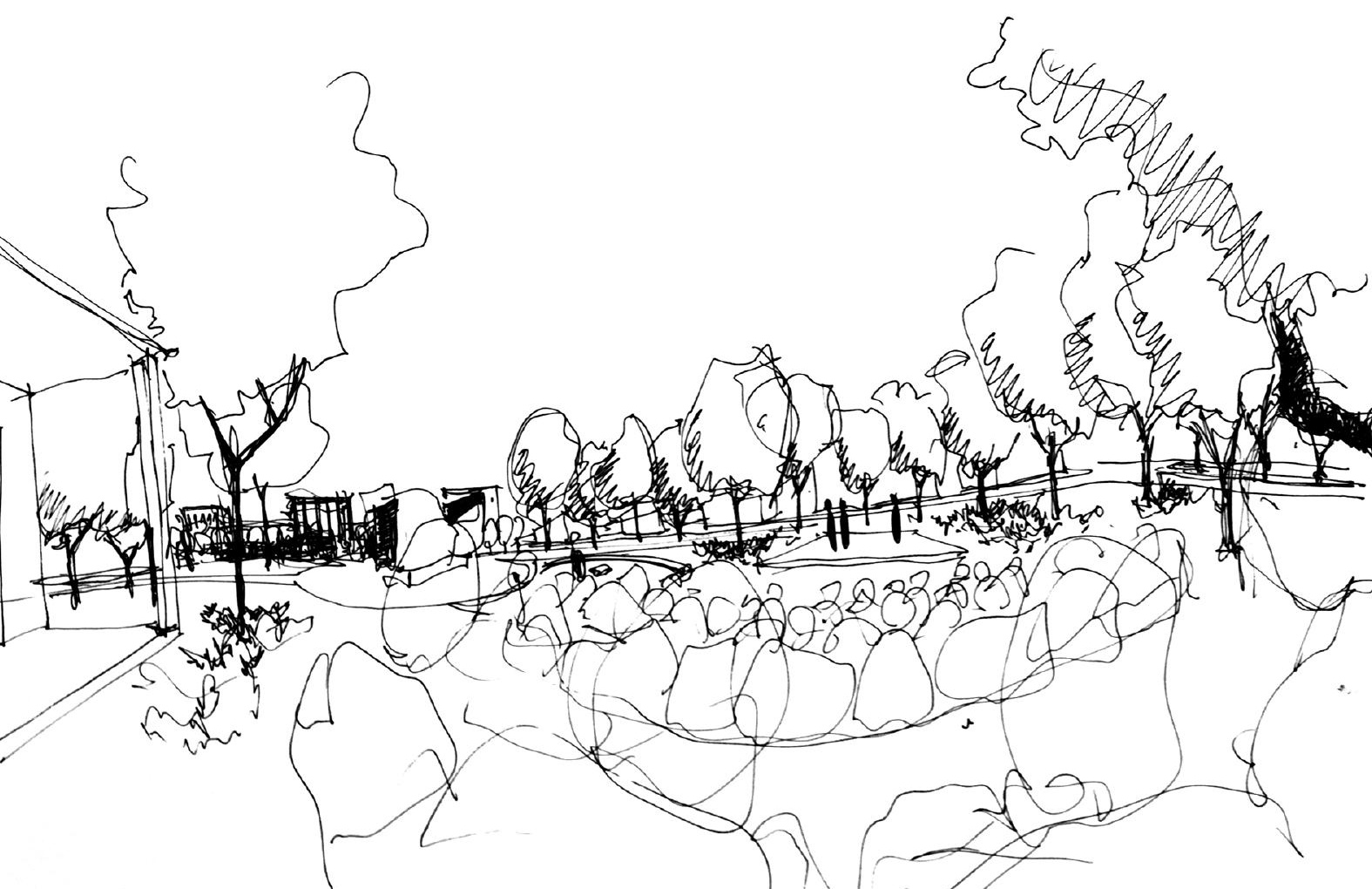


No espaço limitado para esta apresentação, optou-se por uma síntese da investigação da oficina. A relevância deste intercâmbio, no entanto, passa pelo seu impacto na averiguação de boas práticas para o património da llha, procurando "como próprios da terra, de habitá-la" (excerto de Os Lusíadas entalhado na Pedra Sagrada, na Praça 16 de Junho), reconhecê-la e conservá-la.

\section{LEGENDA}

\begin{tabular}{|c|c|c|}
\hline Escola Primária & Anfiteatro aberto & Pedra sagrada \\
\hline Hospital & Proposta para casas Docentes & Mercado de Peixe \\
\hline Área de Restauração & Atual Centro comunitário & Pontão \\
\hline Igreja & Espaço de exposição & \\
\hline
\end{tabular}
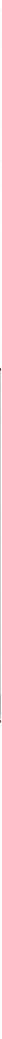


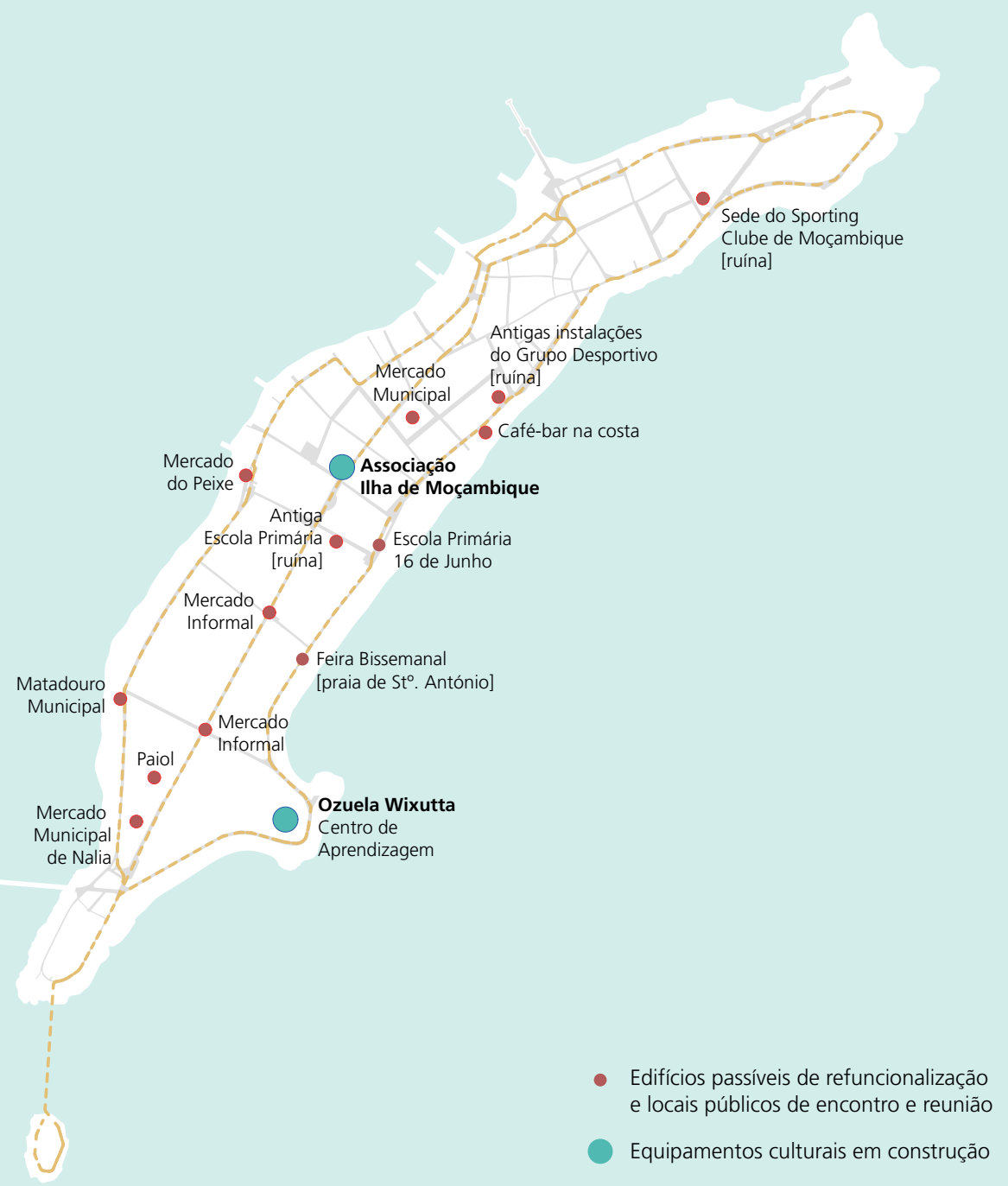




\section{REFERÊNCIAS BIBLIOGRÁFICAS}

Arquivo do Património Cultural/ Instituto de investigação Sociocultural, CX. Nampula, XI, Monumentos e Locais Históricos, 4

FONSECA, Pedro Quirino da (1968), "Breves notas sobre a evolução da habitação e construção em Moçambique", Monumenta: Publicação da Comissão dos Monumentos Nacionais de Moçambique, (4), 45-48. MACHADO, Joaquim José (1879), "Relatório dos trabalhos executados pela direcção das obras públicas da província de Moçambique durante o anno de 1877", Relatórios dos Directores de Obras Públicas e Outros Documentos 1876-81, Primeira Série. Lisboa: Imprensa Nacional, 91-131.

MIRANDA, Elisiário (2013), Liberdade \& Ortodoxia: Infraestruturas de arquitetura moderna em Moçambique (1951-1964). Dissertação de doutoramento apresentada à Escola de Arquitetura da Universidade do Minho, Guimarães.

MORAIS, João Sousa (2001), Maputo, património da estrutura e forma urbana, topologia do lugar. Lisboa: Livros Horizonte.

Portaria n. ${ }^{\circ} 15$ 366, de 3 de maio de 1955. Boletim Oficial n. ${ }^{\circ} 22$, I Série, de 28 de maio de 1955. Direcção Geral de Administração Política e Civil (classifica o conjunto urbano da "cidade de pedra e cal" da llha de Moçambique). 


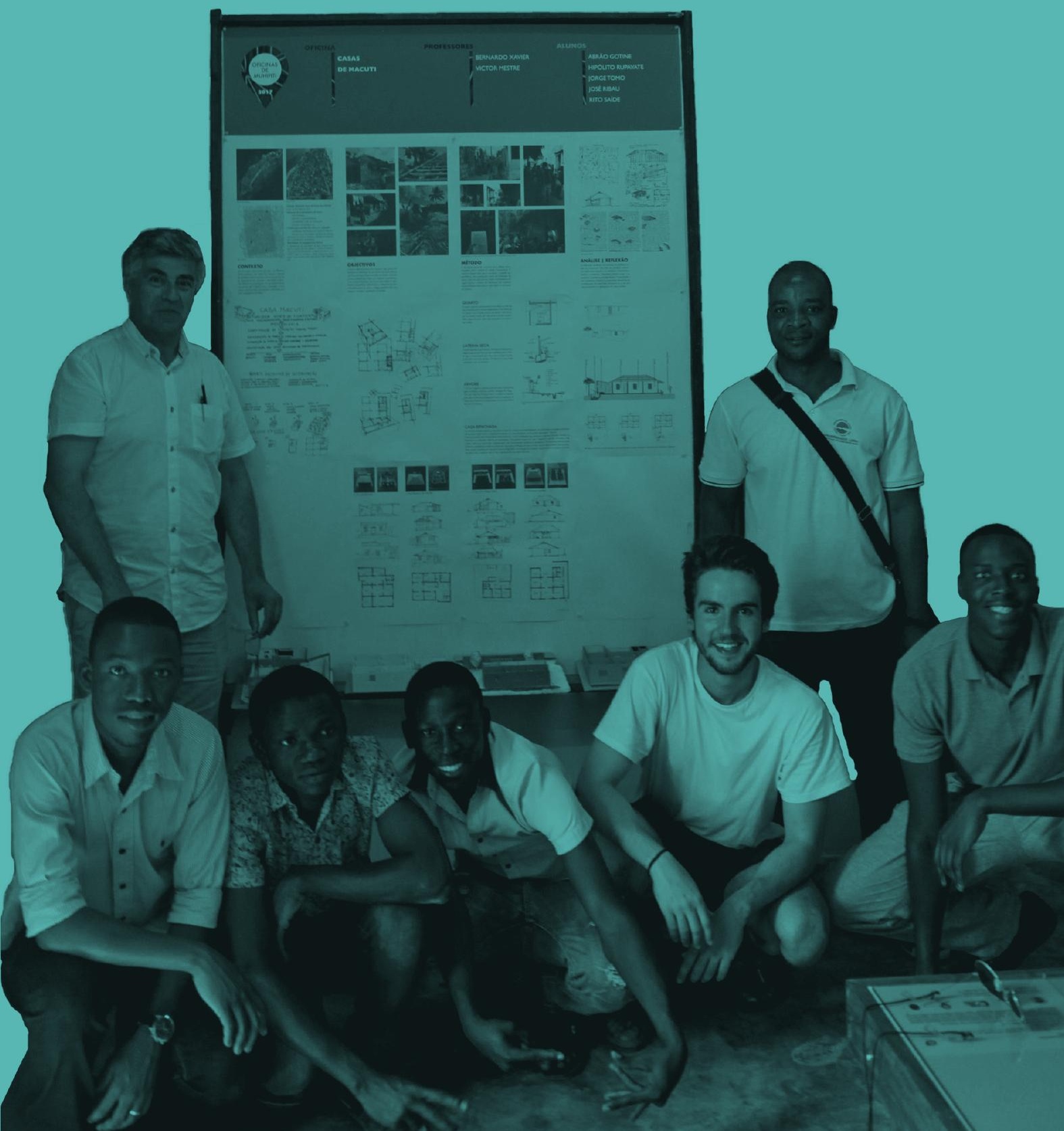



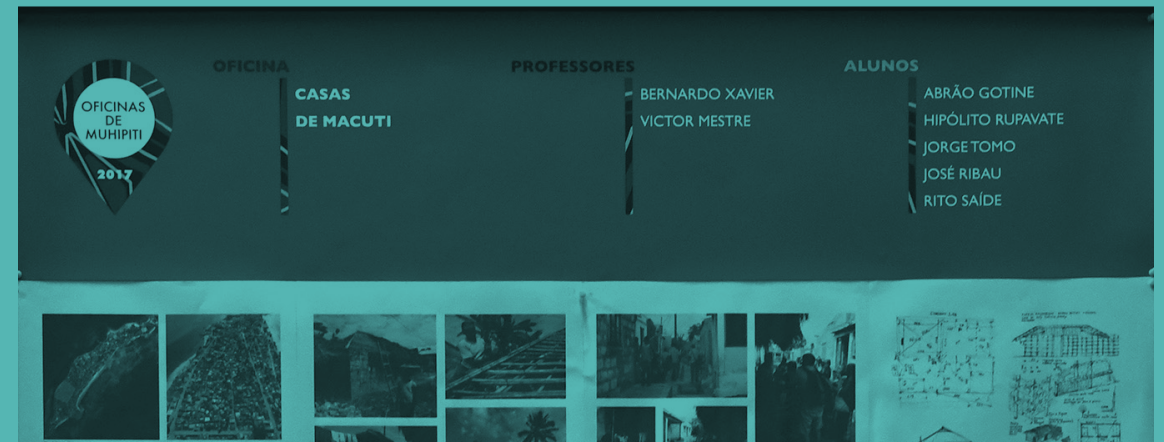

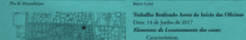

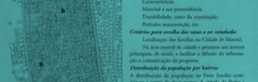

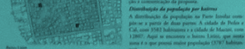

CONTExro

$=-5=$

Fing CASA MACUTI

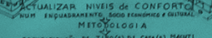
ar 1n플

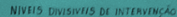

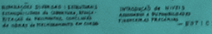

$= \pm \equiv$

\& 4 \&

"I "EII EI:

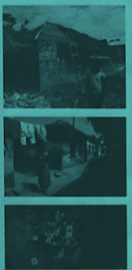

OBJECTIVOS

$=$

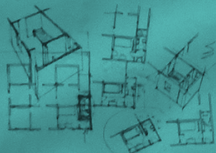

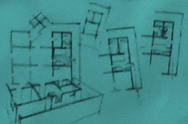

\section{目围回圆}

fint का तथा तथा $\frac{1}{2-1}$ $E I I$
$E+1 !$
$E+1$

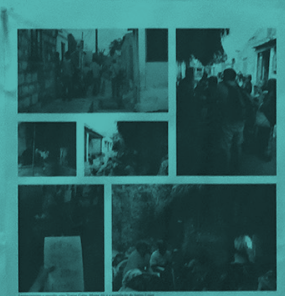

MíTODo

$\equiv-5=$

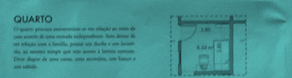

Larema sea

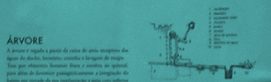

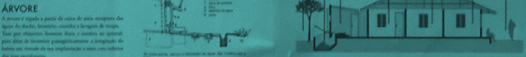

सt ment

s. $\rightarrow$.

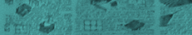

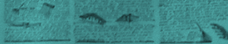

\section{ANALLSE | REFLEXÃO}

$+=$

(II) 18

2.. 110

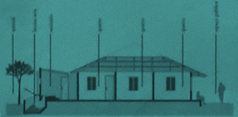

GSA RENOYAOA

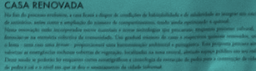

Fमㄹ

ती

$x^{x}+3=0$

Tin nim

जिक्षेत 10

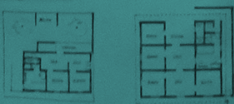

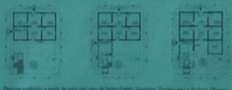

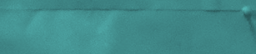




\section{CASAS DE MACUTI}

\section{Bernardo Xavier Victor Mestre}

\section{Missão-encomenda previamente formulada}

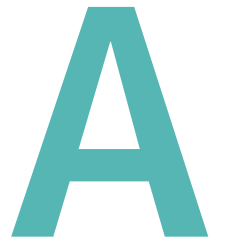

par com a oficina do Plano Diretor de Refuncionalização da Fortaleza, esta tem sido oficina-tema usada como exemplo do que e como o pretendemos fazer, ou seja, do conceito que preside ao evento. Porquê? Porque reproduz a ideia de potenciar a instalação da universidade na Ilha como forma de criar efeitos económicos e sociais que de facto instalem um novo modelo de desenvolvimento que melhore as condições de vida dos residentes, proporcionem uma melhoria das condições de acolhimento dos universitários e visitantes e, ainda, promovam uma vaga de fundo de reabilitação do edificado dentro de lógicas de valorização e desenvolvimento integrado do património cultural, material e imaterial, da Ilha. A encomenda é muito simples: desenvolver um reduzido número de projetos-tipo para intervenção de reabilitação em algumas casas (de famílias que para isso se voluntariem) do Bairro de Macuti, que com recursos mínimos melhorem significativamente a qualidade habitacional e dotem cada fogo de um lugar pago de alojamento de estudante universitário, gerando assim uma forma de rendimento adicional com impacto significativo na família. A intervenção tem de se pautar por um respeito extremo pelas características construtivas e hábitos residenciais. Impõe-se desde logo uma identificação prévia das famílias voluntárias, pela equipa da FAPFUL, por forma a que o trabalho da oficina possa começar por uma visita e levantamento das casas, bem como uma conversa com as famílias por forma a tomar conhecimento dos seus requisitos e expectativas, bem como a integrá-las no processo. 


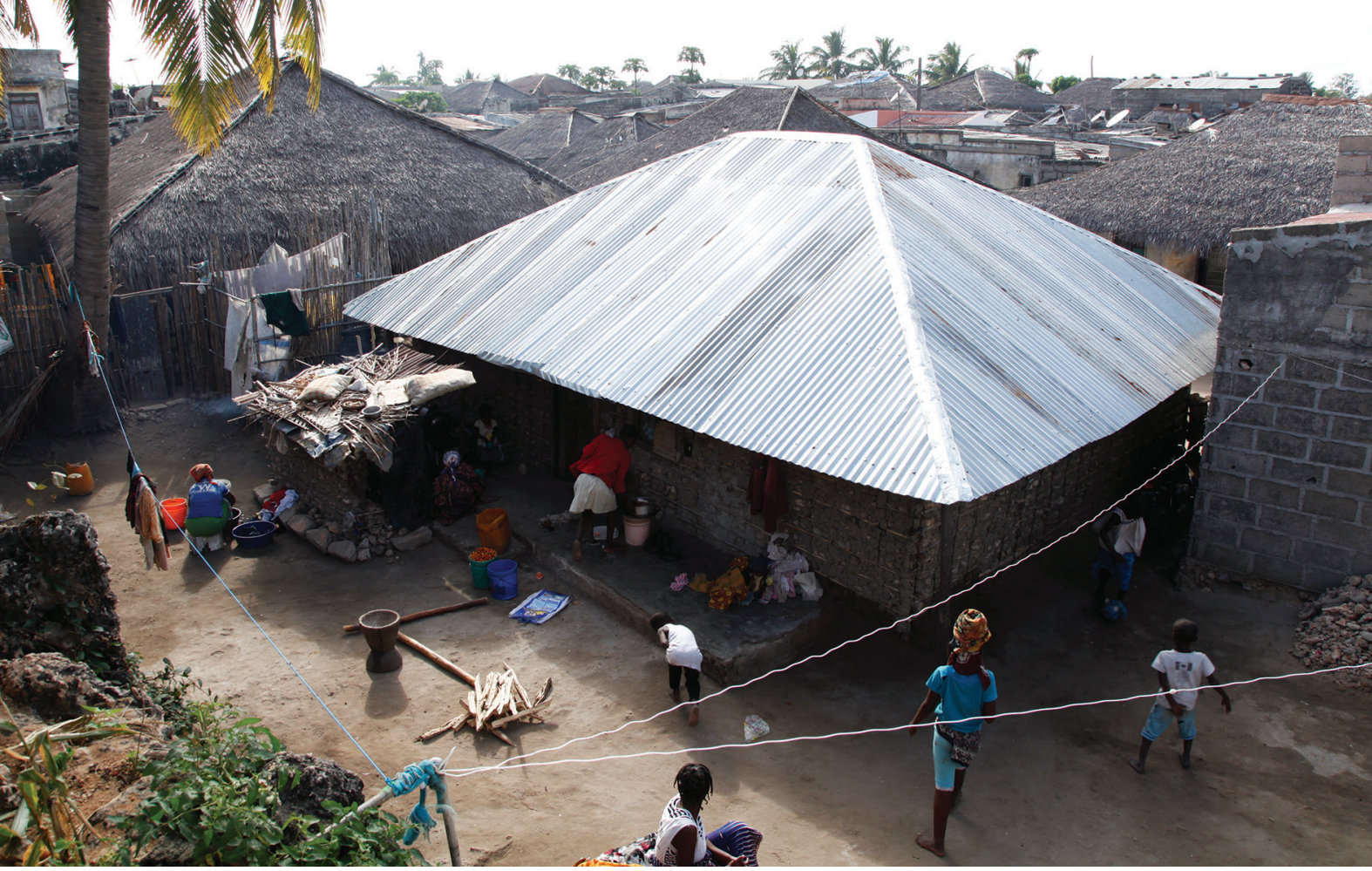

Refiro-me à habitação no sentido do espaço que acolhe as funções familiares decorrentes do ato de residir. Não estou assim, neste sentido, a falar apenas de espaço construído ou das construções. Estou, sim, a referir-me ao conjunto de espaços, abertos ou não, que o núcleo familiar usa diariamente para satisfazer as necessidades domésticas dos seus membros. O espaço aberto e polivalente do quintal, a casa propriamente dita e as dependências, o espaço semi-protegido do alpendre, a sombra da varanda ou de uma árvore suficientemente encorpada são parte integrante da noção de habitação que aqui uso (Carrilho et al., 2001: 5).

\section{A GEOGRAFIA E O CONTEXTO SOCIAL E CULTURAL}

Como sempre, os contextos territorial, social e cultural da casa de macuti, da llha, surgem fundidos pela sua interdependência de séculos de instalação de diversas comunidades. A geografia é caracterizada pela Ilha no centro da baía que a protege e lhe potencia uma microeconomia de base familiar. O frágil casario da cidade de macuti, anichado ao chão da antiga pedreira, protege-se dos ventos, mas sofre com os problemas de drenagem da pluviosidade forte. As casas de alvenaria de piso térreo e os sobrados senhoriais, exprimem uma identidade soberana numa volumetria de matriz canónica austera e densa, com escala e harmonia. 
A llha acumulou sedimentos de diversas culturas em viagem, adaptados às suas particularidades. Na cidade de pedra e cal, transparecem os quintais rodeados de muros altos. Muros de sombra aos quais internamente se encostam alpendres, caramanchões, por vezes as escadas de alvenaria que acedem às varandas altas das traseiras dos sobrados ou aos extensos terraços de onde se avista o mar. No quintal, tempera-se a força do calor com as árvores de fruto, o que contrasta com o rigor árido das ruas de areia e fachadas de tom pastel. No quintal, de novo, que até tem mais ares de pátio, veem-se poços e cisternas com elaborados sistemas de caleiras para a recolha gravítica da água dos diversos terraços construídos num sistema em que (de baixo para cima) a argamassa cobre estrados de grossos troncos de mecrusse, onde se apoiam transversalmente os barrotes que suportam a lacalaca (ver infra) e, finalmente, as lajes de pedra de coral revestidas por uma mistura de cal, gordura vegetal, carvão moído, areia fina e raízes de murrapa, que garantem a estanquidade, mas todos os anos têm de sofrer manutenção (Lobato, 1966).

Na cidade de macuti, a sombra possível é a proporcionada pelo prolongamento das coberturas, protegendo a varanda elevada do chão, em alvenaria rebocada, que forma um banco ao longo da frontaria. A rua e o quintal medeiam a vida social que decorre entre vizinhos numa extensão da vida familiar. Raquel Soeiro de Brito sintetiza:

As casas, pequenas, quadradas ou ligeiramente retangulares (a grande maioria poderá ter $8 \times 9 \mathrm{~m}$ de lado), são na sua quase totalidade de pau a pique, revestidas de terra amassada, e hoje, a maior parte caiada de claro e com rodapés e umbrais de portas e janelas de cores vivas. Grande parte delas à primeira vista parecem autênticas casas de alvenaria, e só percorrendo as vielas e observando as traseiras há a certeza do tipo de construção. A par destas, certo, existem outras não caiadas e até só ainda de olas. [...] Todas estas casas comportam uma sala de visitas e um ou dois quartos de dormir - mais raramente três. Por vezes ainda no quintal ou na varanda se constrói outro minúsculo quarto, reservado às crianças ou a aluguer. O mobiliário é sempre constituído por mesas, cadeiras, bancos, camas de madeira e cordame de cairo e várias esteiras para dormir (Brito, 1970: 10). 


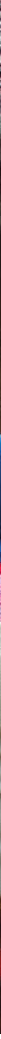

O pequeno poço tem lugar incerto, por vezes no quintal em frente de uma casa, outras numa confluência de ruas. Na informalidade foram-se acomodando sucessivas adições, as casas cresceram sobre as ruas, os anexos construídos nos pequenos quintais de vedações de caniço transformaram-se em casas e, assim, retiraram área aos logradouros e às ruas. Estes bairros são estruturas orgânicas instáveis, com um pulsar vigoroso provindo da vida das suas comunidades.

\section{PROBLEMAS}

Uma prospeção, identificação e inventariação sumária dos problemas sociais, económicos e ambientais observados no âmbito do habitat da cidade de macuti, foi a primeira tarefa deste grupo de trabalho. Teve foco no Bairro Lithine (buraco ou cova, em língua local), no qual vivem 3.787 pessoas, e foi iniciada pelo contacto direto com os representantes da comunidade, a quem se expuseram os propósitos da investigação e os objetivos desta oficina. Depois, com o seu apoio (do qual destacamos o do secretário Tomás Gaita e o do seu assessor, como tradutor, Mussa Ali), decorreu o contacto com a população sobre os problemas de 
habitabilidade das casas. Tornou-se óbvia a necessidade de visitar as casas, para o que foi selecionado um número restrito das que seriam submetidas a levantamento desenhado e, subsequentemente, a projeto de requalificação.

A generalidade dos problemas identificados pelos habitantes decorrem do sistema construtivo e dos materiais, surgindo em primeiro lugar a falta de estanquidade das coberturas e a dificuldade de aquisição do macuti pela sua crescente escassez e elevado preço. Mas também a dificuldade em reparar ou repor a lacalaca nas paredes de caniço. Poucos referiram as questões infraestruturais, como o saneamento, a drenagem ou as condições de confeção dos alimentos. Assim, a discussão acabou por se centrar nas eventuais alternativas à utilização do macuti, em particular na utilização de chapa de zinco, seguindo-se a substituição das paredes de caniço por alvenarias de blocos de cimento. A reunião decorreu diante da casa do secretário e essencialmente com mulheres. Esta casa tradicional é quase um caso único na sua rua, pois as demais são quase todas já em blocos de cimento, praticamente sem janelas, com coberturas de laje de betão ou chapas de zinco. É a evidência das profundas alterações em curso e permitiu discutir mais facilmente as vantagens e desvantagens técnicas e culturais dessa transformação. Particularizaram-se as questões da ausência de ventilação nos sistemas em crescente implementação; as vantagens do prolongamento dos telhados, que não só abrigam as paredes da chuva, como proporcionam sombra; e a importância do pequeno quintal como extensão do espaço interior e privado da casa. Por fim, abordaram-se as questões da herança cultural e da identidade. As mulheres, que tomaram a palavra, reconheceram, sem reservas, que as casas de bloco de cimento são muito mais quentes e abafadas, contudo, tornaram claro que o problema principal não é esse nem as casas em si, mas a dificuldade em suportar o custo das chapas de zinco e, ainda mais, aquisição de blocos de cimento.

Foi esta a forma de se passar a discutir a viabilidade de melhorar o rendimento das famílias, no contexto da instalação da Unilúrio na Ilha, designadamente através da adaptação de um compartimento por casa, uma unidade de alojamento para um estudante. A reação foi muito positiva, colocando-se, uma vez mais, a questão do financiamento dessa adaptação. 
sua durabilidade a 1-2 anos. Uma casa de dimensão média necessita de 250-300 molhes de folhas que custam 30 meticais cada, face a um rendimento médio diário na pesca de cerca de 100. Além da macarazi é comum o recurso à folha de coqueiro, revirada e enlaçada ao caule central, formando uma telha standardizada, denominada hambeka, mas cuja obtenção tem semelhante dificuldade.

A cusa do Sr. Amisse e do Irmáo Xarama, localizada no barrro Estru, fotografada a desanbada no momanto em que se encontruva a ser renovada, permetiu registar os procassos construtivos da fundacad a cobertura, passundo palas parnebs deangrududogda cana, preenchido com pedra cotalina. As amar "X racoes em "fila"de borracha raciclude

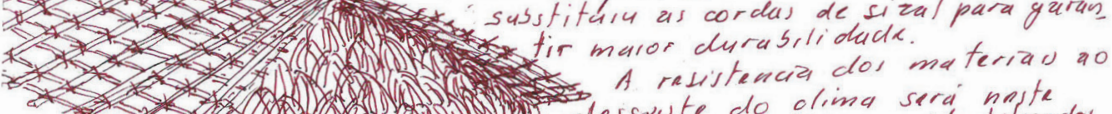

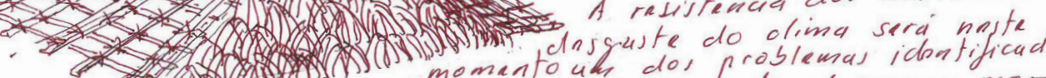

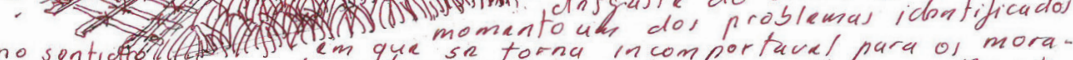
dores manteren oste sistema tradicional, designado por Macet.

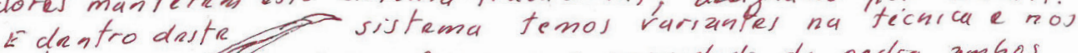
materiais. pau a Pique e o engraclado de pedra, ambos recorrendo á cana, gaj a base estrutural dáas paredes. que após o reboco final nao se percepcionam. Ao paci-a-pique esta assouado o termo laca-laca qua tendencialmantre reproduz ama parede marto esticito, cons

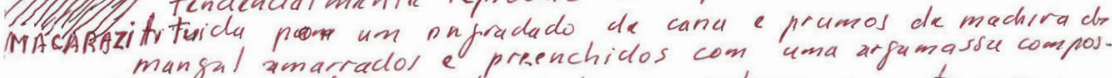
ta por aresa fina e cal. Anbos or sistemas encortram-se en extintas alada que o enfraclado ob pectra se mantenta nas recons: trucoés. O bloco de betai encontra-se em acentuada pirof-astaj.

As cobarturas da casa Macat, onwatram-Ja igualmente em transicuo para a shapa de zinco contado arncta in abjerva una na. maro' sifnifricativo da casas com cobertara degetal com "telhas" Macuti coqueiro, capim ou macarazi. o trmpo dax apanha destas mas tarrais clarxou da ser a refra para as pessoal que os comercizlizam innlo qua no upunbarnm a folba do cogueiro arrda verdn reduz a dura bilidude de trés anos pura um ano. A "telha" de coquesro é executadu a partior de una folha $2 \mathrm{~m}$ bruto no local da armacav. E executada palo artesad/constoutor ou pelo propriaturio. A esta teitha esta associada a case Macut, qua apesar da sua usbstitaricas pela follay Macarazl, continua a ser ennominado por macerts.

os mothos de macurazicustam cerca de 30 meticals a uma cara podo acolher therca de 250 a 300 molhos. A casa do Barro Esteu uslava a ser ranovada palo mertre Nahota e pelo ejudunte Dauto no dia $26 \mathrm{dnzulho} / 7$
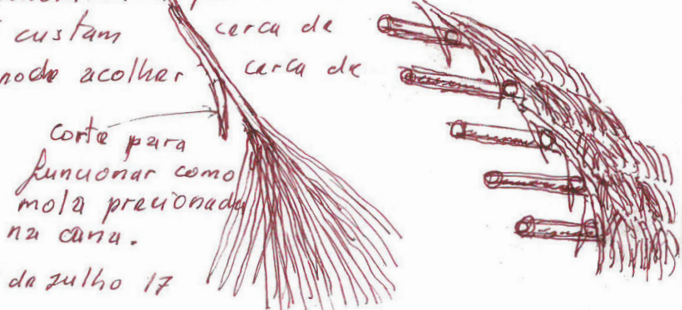

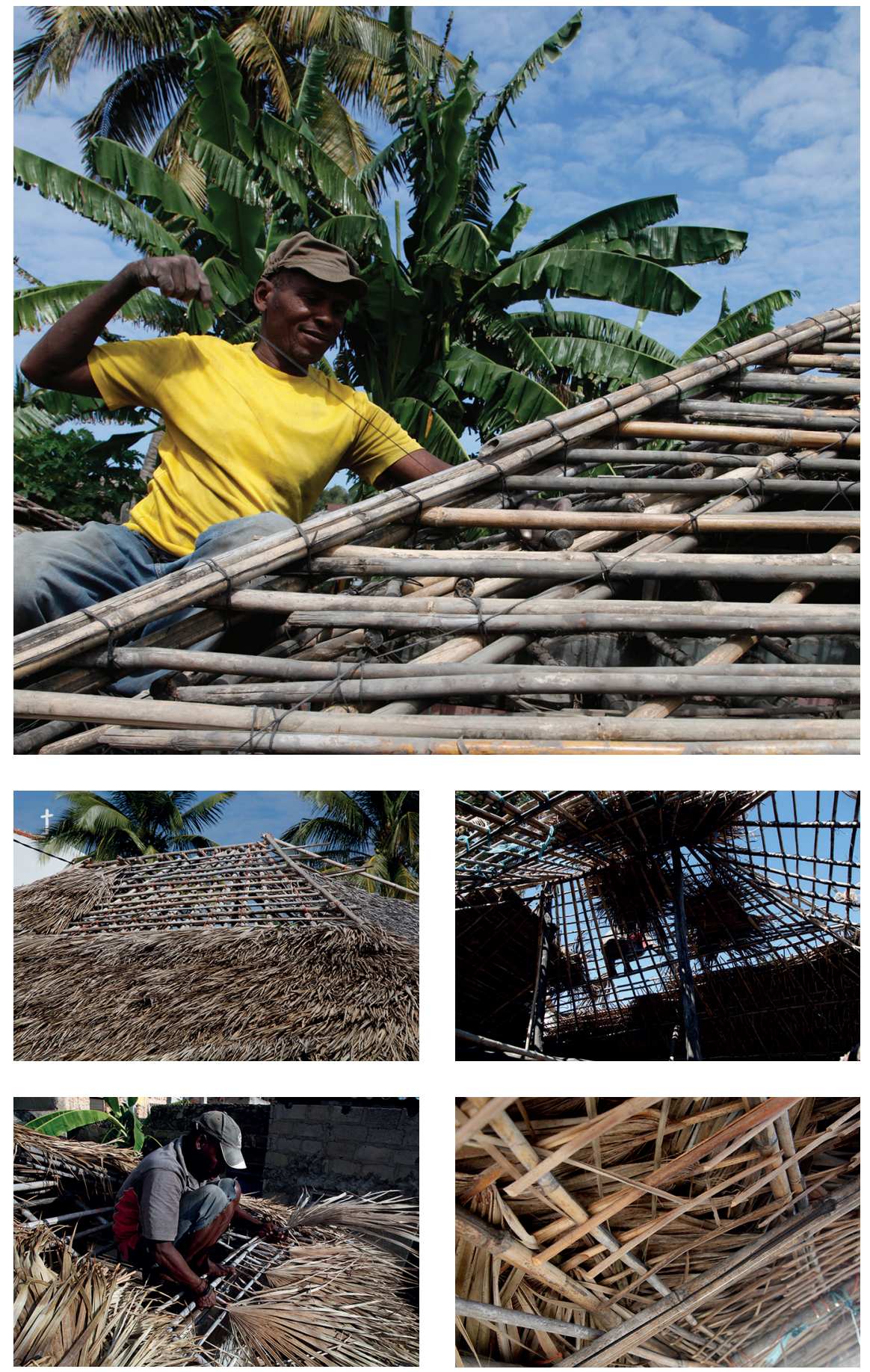
ILHA dS MOCAMBIQUE BAIRRO LITINT - MACUTI CASA de Anly Sadique $x$ andy

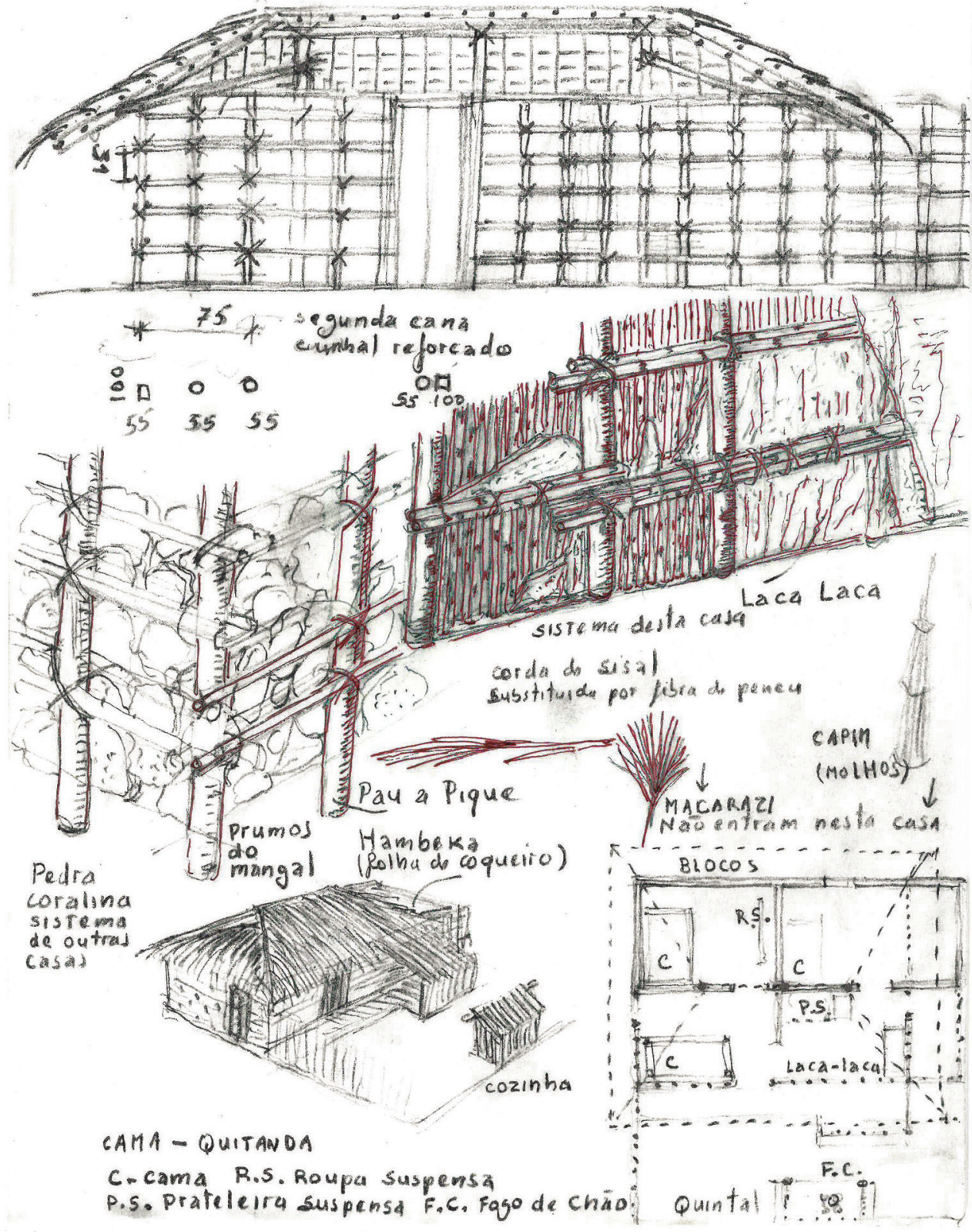


No contauto directo com a populaces do burro de Esten, foi possival estabalacer dialogo com propretaíos e construtores artesunais, de

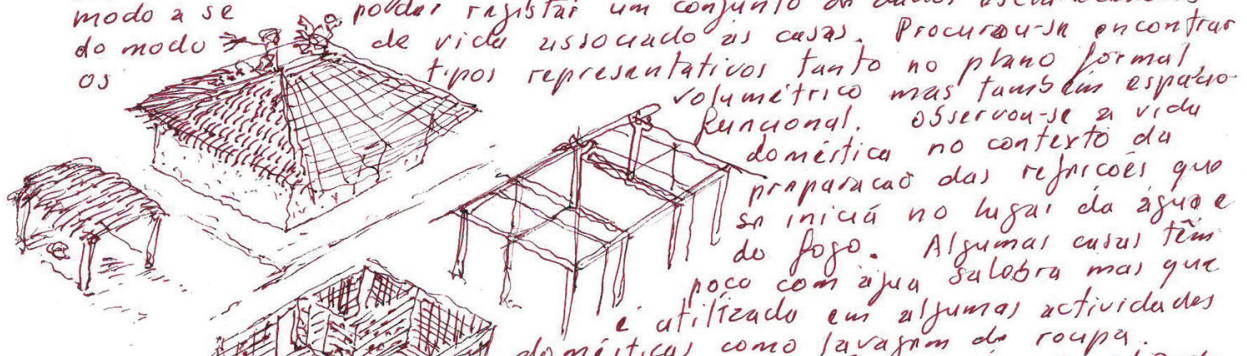
doméstical como lavajuon de roupa.

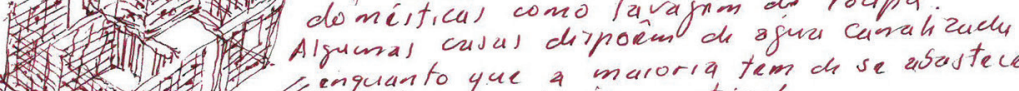
- fenquanto que a maroria tem de se abastecer conpra a lanha 1 . Na praparacao do Jogo de chas o agrajado

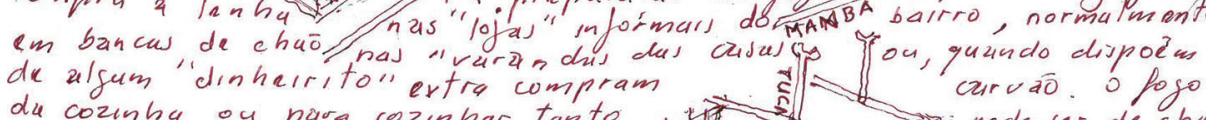
du cozinha ou para cozinhar tanto pode ser de chao

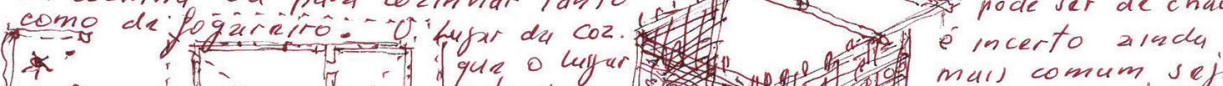
00

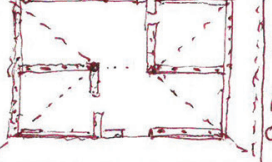
de cana. Coziniar no axterior da casa e uma constánte e as palo calor greado gna fornalha. da caba a tear fogo e tambrins

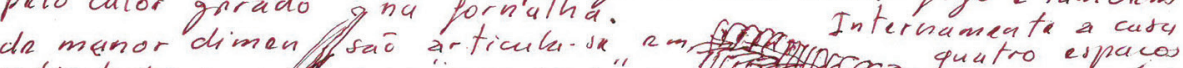
arficulados por uma "concupcuo" de "suatro espacos

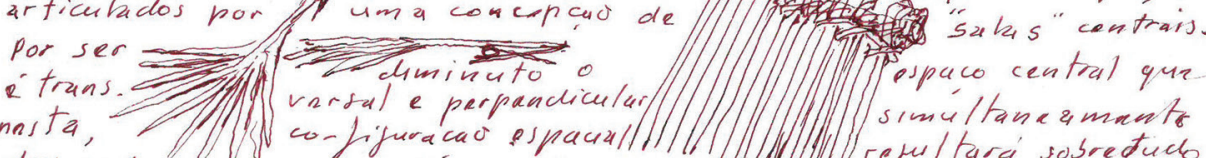

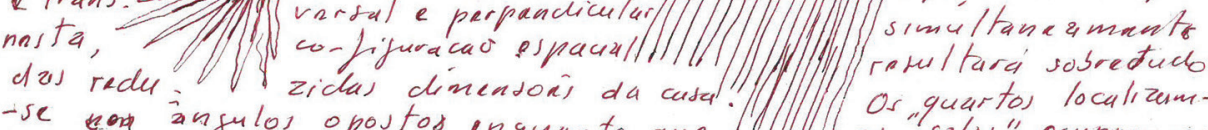
-se ena angulos opostos en quan to que ld angulos equivalentes mais a zona central, "que fica aberta.

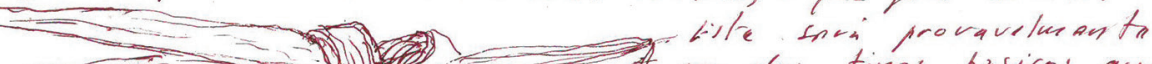
Jul un dor tipos basicos qua A tionica rado ate se fixarnm graclualuente melho celulta da construcas de umu armacas. dupla de parredss de cana con pranos cte mangal umarrados con corda des sisal ou de $\hat{c o c o}$. No interior da "gusola" intagram - se pedras de coral dispondo-se com grande dostreza do mastre para derxur poucos vazios entre elas. A cuega das padras deve uporar nas pedras infrerores e nat nas canas que apanas as contêm. 
Em termos de organização do espaço, o tipo de casa mais comum tem quatro compartimentos ou, nas de maior dimensão, seis, podendo o central ser aberto para o pequeno quintal. Estes tipos ter-se-ão mantido praticamente inalterados, uma vez que o que ali vemos hoje corresponde ao descrito por Alexandre Lobato em 1966 (Lobato, 1966: 90-91).

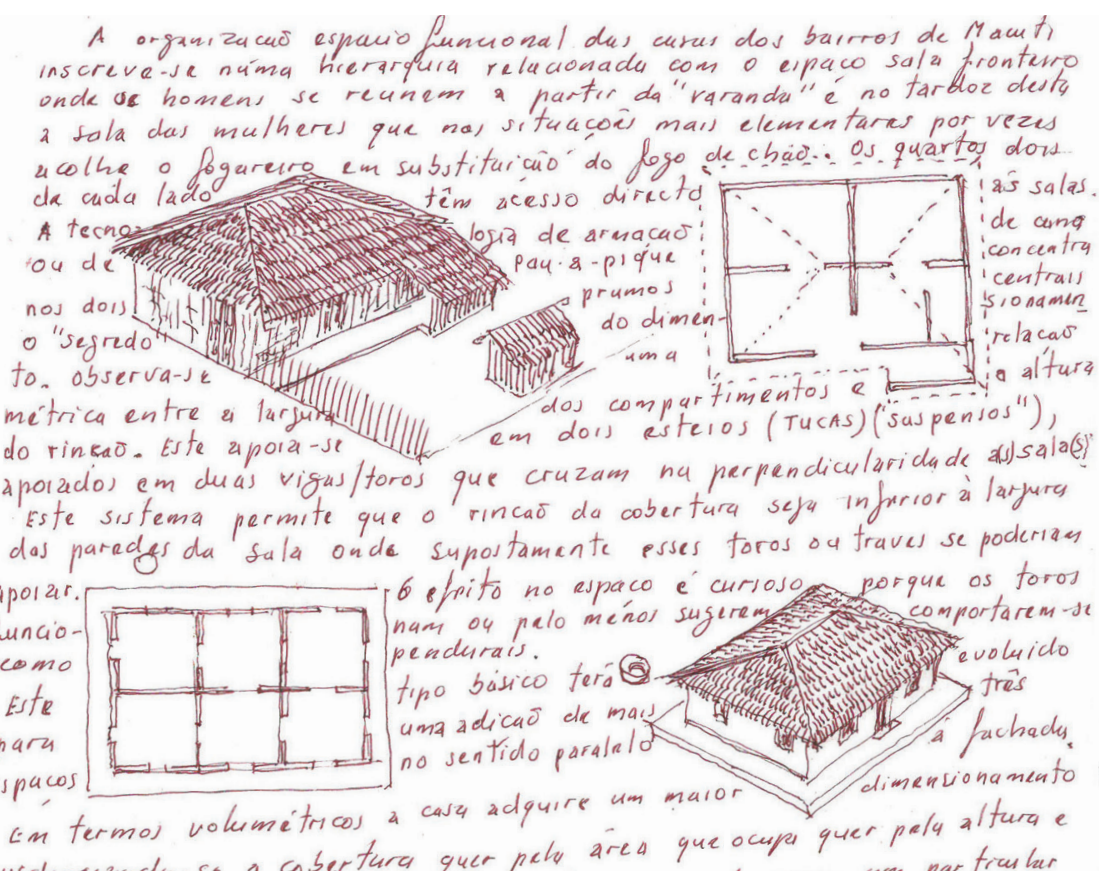

eusdanciando-se a cobertura quer pele area que ocupa quer pely alfura presher

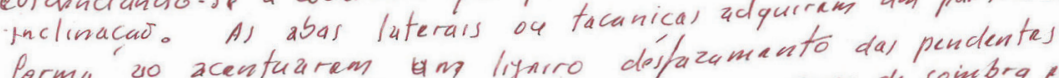

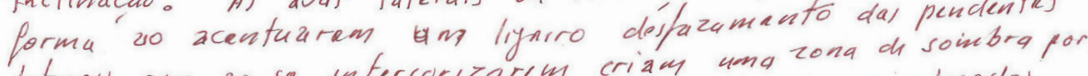
laterais gun 20 se infercoricarem criam uma zona do soins paus jaó colocados onda passu 4 ventrlacao da casa. Alguns paus Jaó colocadoda terco du como cuntras para contramar a flacha das pendenates a undo um par ulfura, apol do-se nas trawessas (toros) amarradas adqui de cuna longitudinais que tosistancia rem uma particulur un madres longitudinais lunvoriando

Todo o conjunto composto por paredes exteriores, interiores e armecus huncionam como um bloco unificudo por cantenas destas intersores da sisal ou tiras de borracha. Sosre os vaos das fixam as armacois

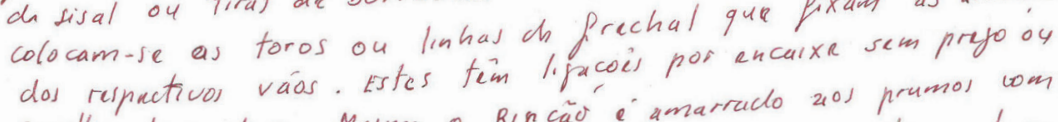

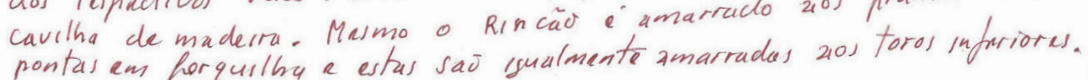




\section{PROPOSTAS}

Uma vez identificados e caracterizados os tipos das casas, as patologias construtivas, a realidade socioeconómica e as principais aspirações dos habitantes, procurou-se estabelecer um método evolutivo de intervenção, uma estrutura reguladora, tipificada e programada. A fase experimental dos projetos e a sua implementação deverão assegurar a flexibilidade entre os contributos multidisciplinares e a articulação com a sua gestão financeira. Para tal, poderá ser crucial, para o apoio às famílias, o Estique, sistema financeiro de microcrédito - provavelmente passando por uma fase inicial a fundo perdido —, com vista à realização dos primeiros níveis de intervenção. O rendimento que a família obtém com o aluguer do quarto de hóspede funcionará como um suporte económico de sustentabilidade do empréstimo e da manutenção da casa, sendo determinante uma programação hierarquizada das intervenções face à evolução do rendimento familiar e decorrente da criação de condições de sustentabilidade e resiliência.
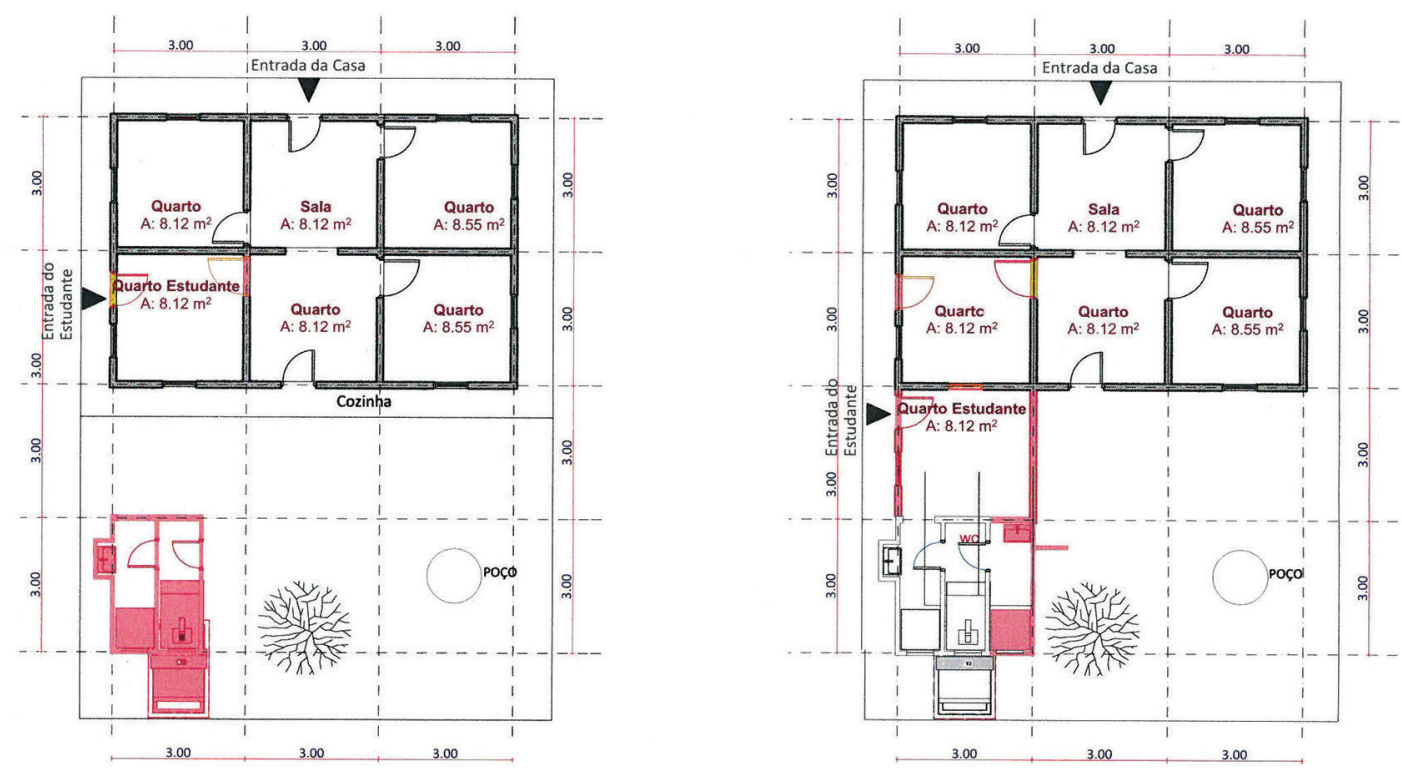
Propõe-se que essa hierarquização seja guiada da seguinte forma: prioridade à salubridade, com destaque para a estanquidade à chuva da cobertura, contenção dos níveis freáticos e ventilação interna da casa; seguem-se a introdução de retrete seca, a limpeza e salvaguarda dos poços e reservatórios, a introdução de uma árvore por quintal para potenciar sombra e frutos; higienização da zona de preparação e confeção dos alimentos e dos compartimentos internos da casa. Em quase todas estas intervenções estão associadas medidas corretivas no plano estrutural e de conservação da unidade arquitetónica.

As ações relacionadas com a adaptação de cada casa ao acolhimento de um hóspede hierarquizam-se a partir do reajustamento de um compartimento preexistente que, para além das condições básicas, deverá ser autónomo, ou seja, com acesso direto ao exterior. Desde logo, nesta primeira fase a casa deverá já dispor de uma retrete, seguindo-se uma zona de banho que terá um lavatório cujas águas, com as do banho e de lavagens da roupa, serão dispersas para uma caixa de areia que comunica com a caldeira de uma árvore entretanto plantada. A maçanica é a árvore mais comum na cidade de macuti e tem a vantagem de ser fruteira, bem como o seu desenvolvimento se enquadrar nas dimensões dos pequenos quintais. Numa outra fase poder-se-á construir um quarto de hóspedes adjacente à casa, ou mesmo autonomamente, associando-se ao conjunto sanitário.

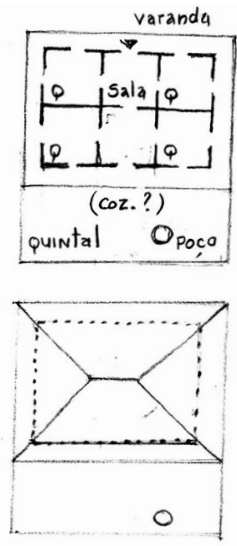

1 CASA. EXISTENTE
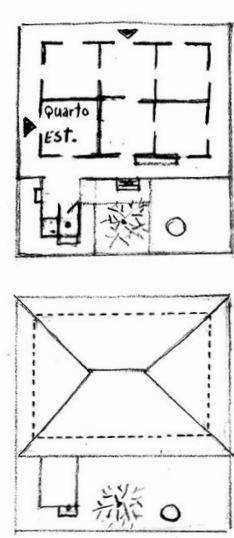

2 QUARTO de ESTUDANTE latrina seca - bantio" (sanitario base) PLANTAR ÁvORE
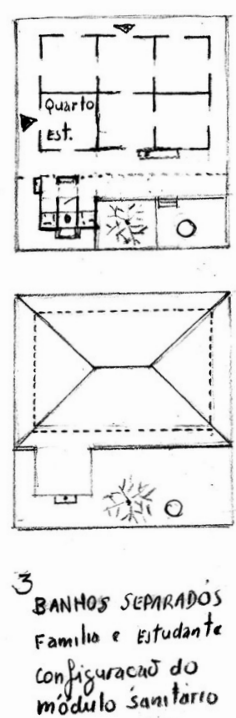
módulo sanitarto
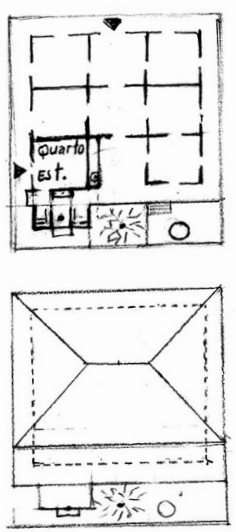

4 AMPLIACAÓ da CASA com dor's Quartos Mantém p móclulo Sanitario sem alteracoes RECONFIGURACAO DA COBERTURA 
Às medidas corretivas que visam a melhoria da habitabilidade e conforto das casas, associam-se pequenas intervenções que visam a sua otimização funcional interna e com o pequeno quintal. Parte da vida diária decorre no espaço exterior coberto, resultante do prolongamento da cobertura, ou de um alpendre recuado em relação ao plano da fachada. É ali que, de um modo geral, se confecionam e se tomam os alimentos em família. A pequena fornalha de chão, localizada no ângulo interior das paredes de caniço revestidas de argamassa para proteção do fogo, constitui um dos gastos mais significativos dos agregados familiares. Algumas casas têm o local de confeção autonomizado, de modo a salvaguardar a potencial propagação do fogo, principalmente nas casas de cana sem revestimento. Regista-se, assim, a relevância do local de confeção e da necessidade de introduzir algumas correções na potencial reintegração deste espaço no conjunto edificado.

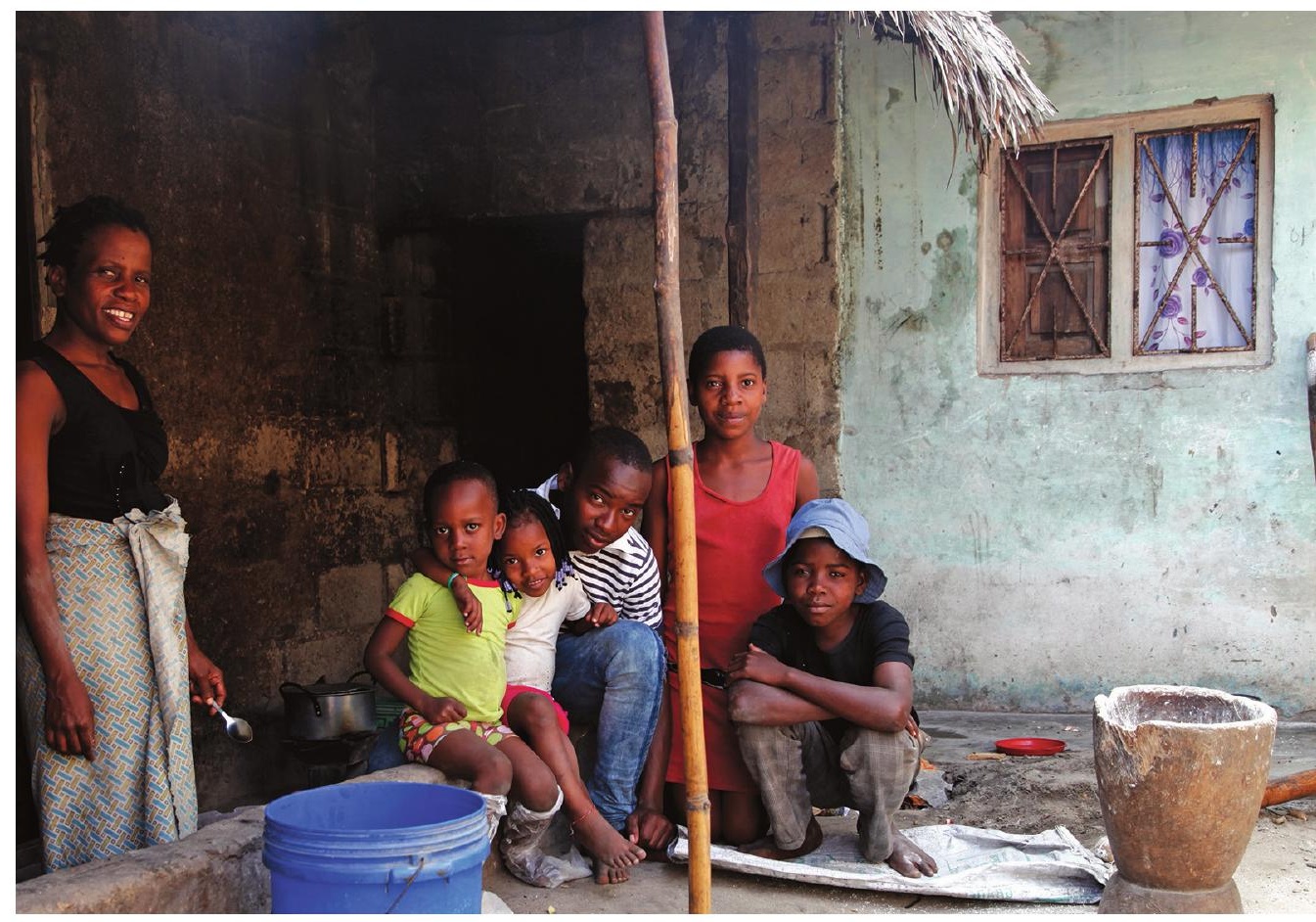


A organização espacial tradicional das casas articula quatro espaços, em que os dois laterais são destinados a quartos de dormir e, os outros dois, ligeiramente maiores, são utilizados como salas (a da frente, diretamente relacionada com a varanda e, por isso, para receber, e a detrás, onde as mulheres convivem em família e confecionam a comida em articulação com o quintal). As casas de seis compartimentos têm um perímetro retangular, centralizando as salas e ampliando em dois o número de quartos, por simetria aos outros dois. Um outro tipo, menos frequente, amplia a casa de seis para nove compartimentos, retomando de novo a configuração quadrangular e uma significativa altura da cobertura. Notabiliza-se o espaço central deste tipo devido à amplitude do desvão e à perfeição das fieiras de macarazi ou de hambeka. Ao analisar os diferentes tipos de casa torna-se claro, pela sua modularidade, como haverá casas que permanecem como foram criadas e outras que terão sofrido acrescentos, sendo essa uma das principais chaves das intervenções.
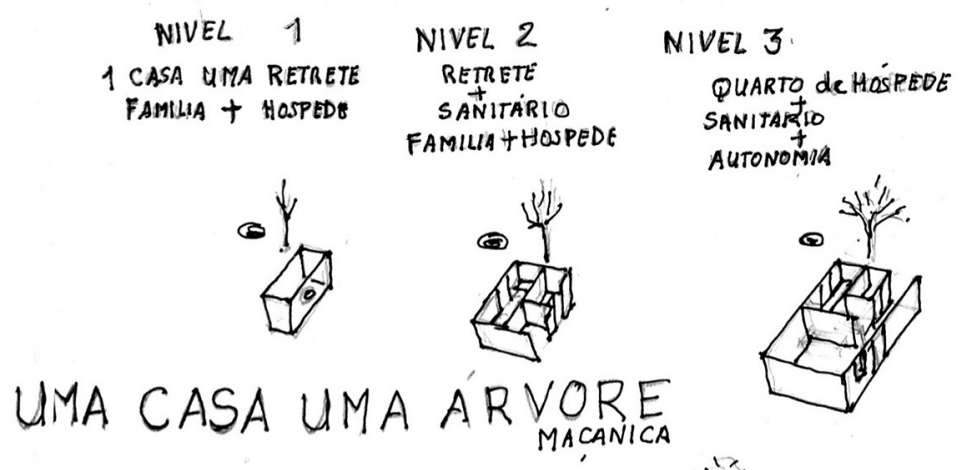

NIVEL 4

CASA UNIFICADA

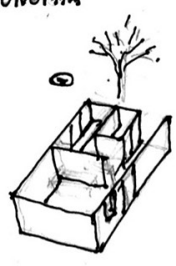

(Q)
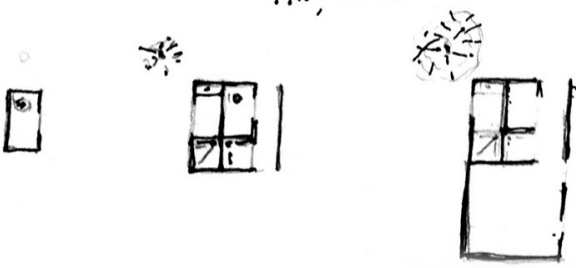

HOSPEDE + FAMILIA

de ACOLHIMENTO

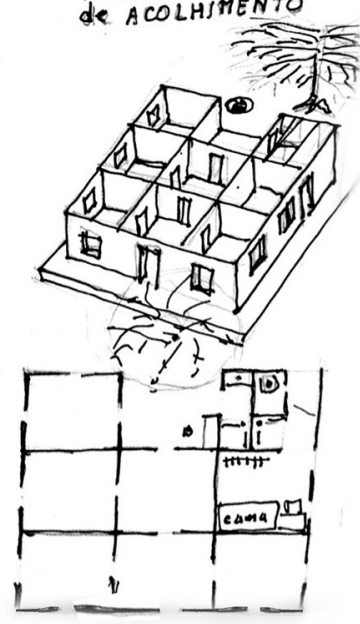




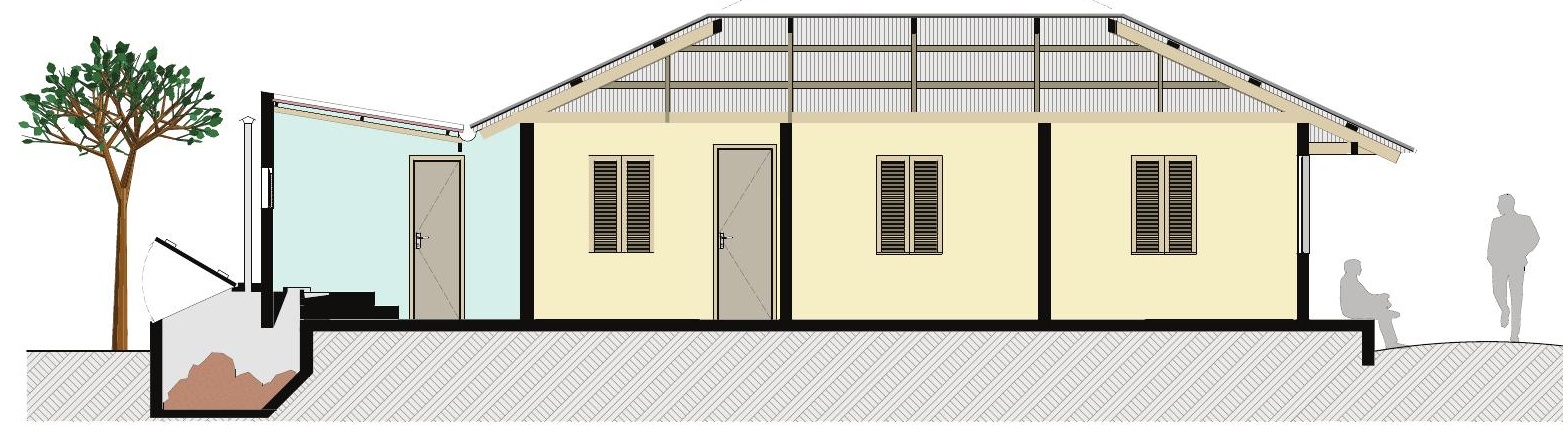

A questão central da salubridade prende-se com a retrete que, em virtude da escassez de água, deverá ser do tipo seca. A condição desta solução é a de permitir a lavagem separada, ou seja, sem introdução da água na cuba da retrete, sendo esta conduzida para a caixa de areia que antecede a caldeira da árvore. É uma condição incontornável pois, por razões religiosas e culturais, é um ato no qual deverá ser possível utilizar abundantemente a água. É também relevante a criação de uma bancada elevada do pavimento (para preparação e confeção dos alimentos) de modo a higienizar o local que deverá manter a sua posição tradicional. No âmbito dos compartimentos, propõe-se a integração de vãos de modo a assegurar a ventilação e, assim, a sua salubridade.
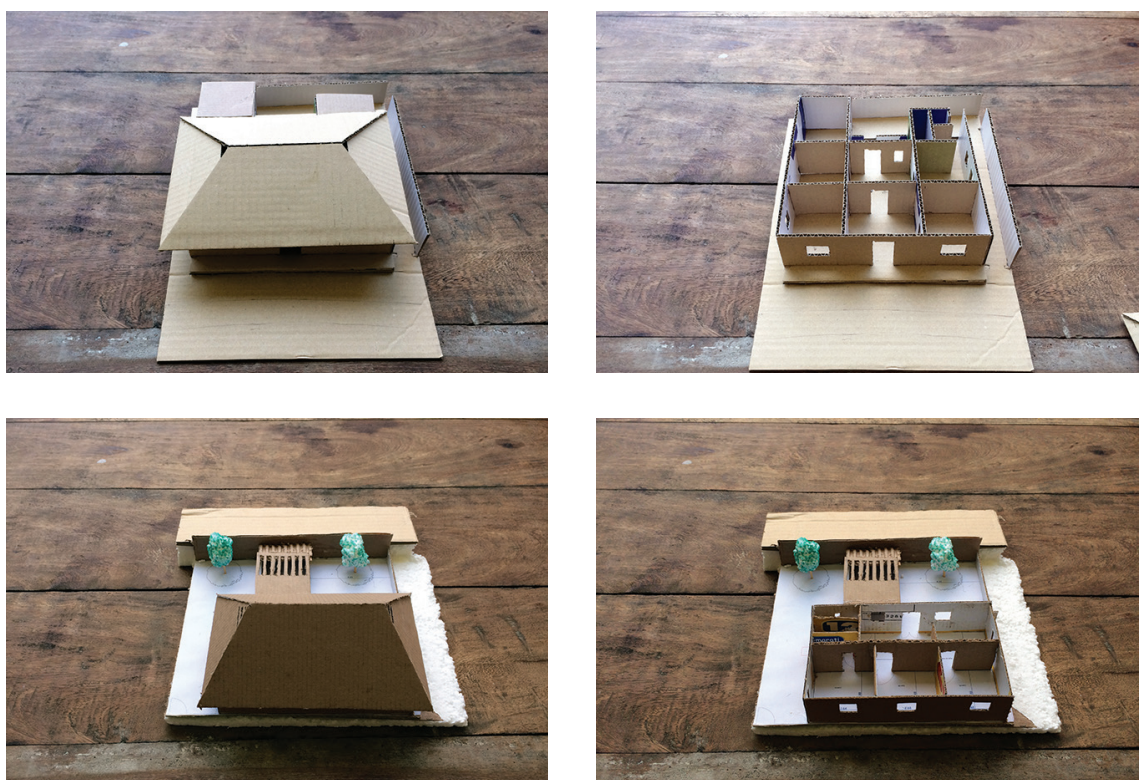
No que diz respeito à substituição dos materiais tradicionais sugeridos pelos residentes, consideramos que se poderá executar, numa fase experimental, um protótipo para melhoramento e correção conforme o seu desempenho. A reabilitação das casas existentes poderá passar por integrar a chapa de zinco e, sobre a mesma, instalar um varedo contínuo de caniço no sentido da pendente, de forma a atenuar o efeito de calor e minimizar o impacto visual. Quanto à construção nova ser feita em blocos de cimento, é proposto o recurso aos blocos de adobe comuns no continente, em redor da llha, podendo ser produzidos nesse contexto ou efetuar-se o transporte da terra e serem enformados no local. Para melhorar termicamente as paredes propõe-se o seu revestimento a lacalaca. Com estas técnicas garante-se a permanência dos artesãos e a salvaguarda da casa tradicional, uma tentativa de atender e acrescentar soluções, como sugere Sandro Bruschi:

Hoje, todavia, é preciso atender à necessidade de casas de muito baixo custo e a condição mais fácil e económica de utilização da chapa metálica verifica-se nas coberturas de águas independentes. Consequentemente, a cobertura com quatro vertentes tende atualmente a desaparecer, toda a organização interior é alterada pela facilidade de organizar quartos com cobertura e estrutura independentes uns dos outros e, finalmente, dado que as coberturas são independentes, não há razão para manter a forma compacta do exterior da casa. (2001: 161).

Propõem-se ainda tipos de casa a construir de raiz, aproximando-as da volumetria, expressão e identidade espaciais das preexistentes, mas incorporando algumas inovações que terão de ser validadas pelos utentes. Para tal, levaram-se em linha de conta a investigação e projetos de arquitetos que há décadas têm desenvolvido trabalho nesta área e de entre os quais aqui se destacam Júlio Carrilho, Luís Laje, Sandro Bruschi e Carlos Menezes. 


\section{EXPECTATIVAS}

As sessões públicas do Oficinas, onde nos foi possível apresentar estas propostas, permitiram constatar o interesse crescente da assistência, misturada com a incredibilidade face a antecedentes não concretizados e à dificuldade em percecionar o potencial funcionamento do que se propõe, em particular no que diz respeito às obrigações de gestão do processo, sobretudo do plano de financiamento Estique.

As possibilidades e expectativas de melhorar as casas terão ficado patentes nessas apresentações e nas abordagens dos representantes dos bairros e das famílias visitadas. Importa auspiciar que este pequeno contributo possa vir a alicerçar-se num ambicioso plano que contenha mecanismos de ajustamento à realidade no terreno.

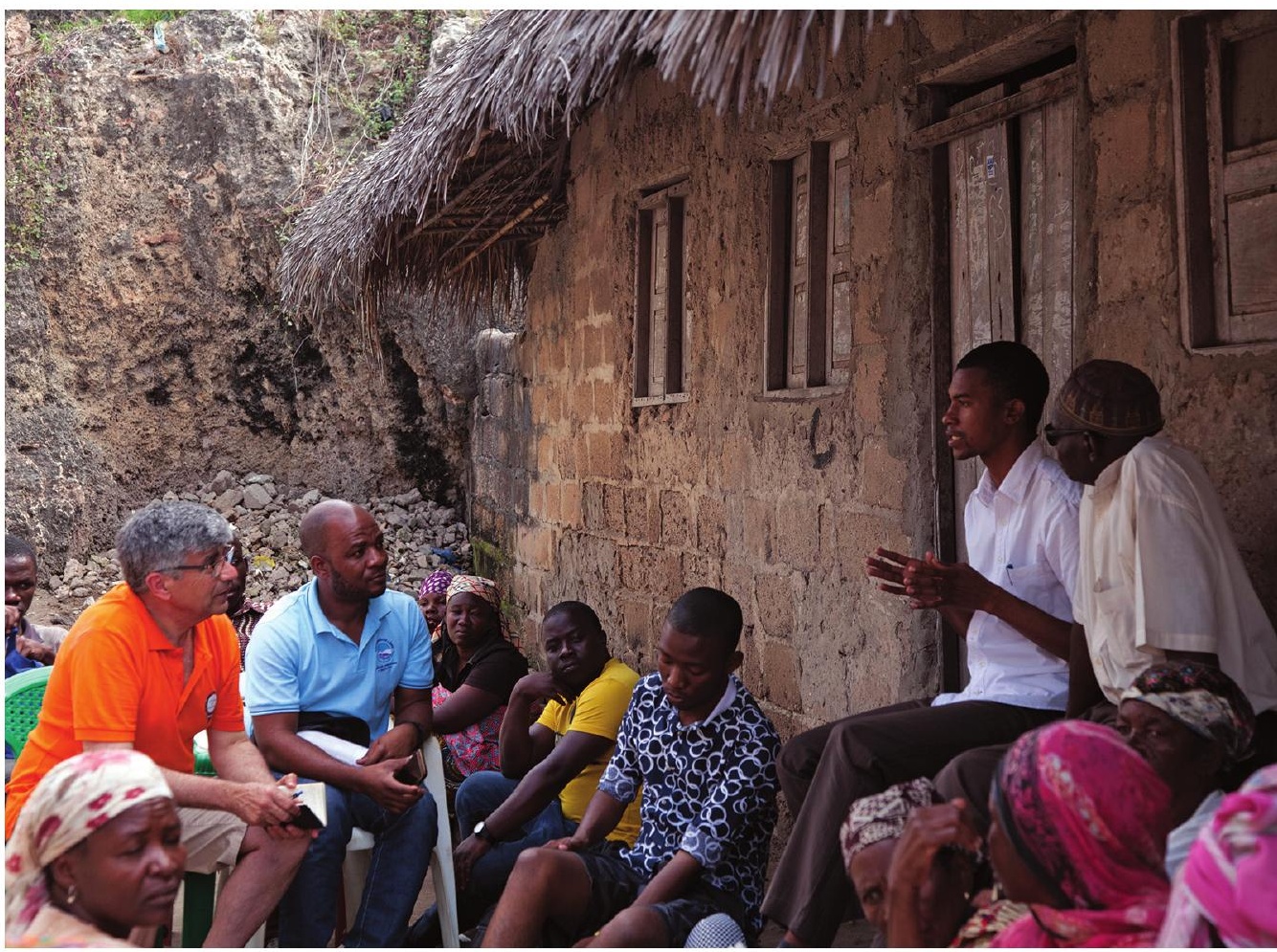




\section{REFERÊNCIAS BIBLIOGRÁFICAS}

BRITO, Raquel Soeiro de (dir.) (1970) "Ilha de Moçambique", Revista Geographica. Lisboa: Sociedade de Geografia de Lisboa, 21, 3-21.

BRUSCHI, Sandro (2001) Campo e Cidades da África Antiga. Dissertação de doutoramento apresentada à Faculdade de Arquitetura e Planeamento Físico da Universidade Eduardo Mondlane.

CARRILHO, Júlio et al. (2001) Um olhar para o habitat informal moçambicano: de Lichinga a Maputo. Maputo: Centro de Estudos e Desenvolvimento do Habitat.

LOBATO, António (1966) I/ha de Moçambique: panorama estético. Lisboa: Agência-Geral do Ultramar. 


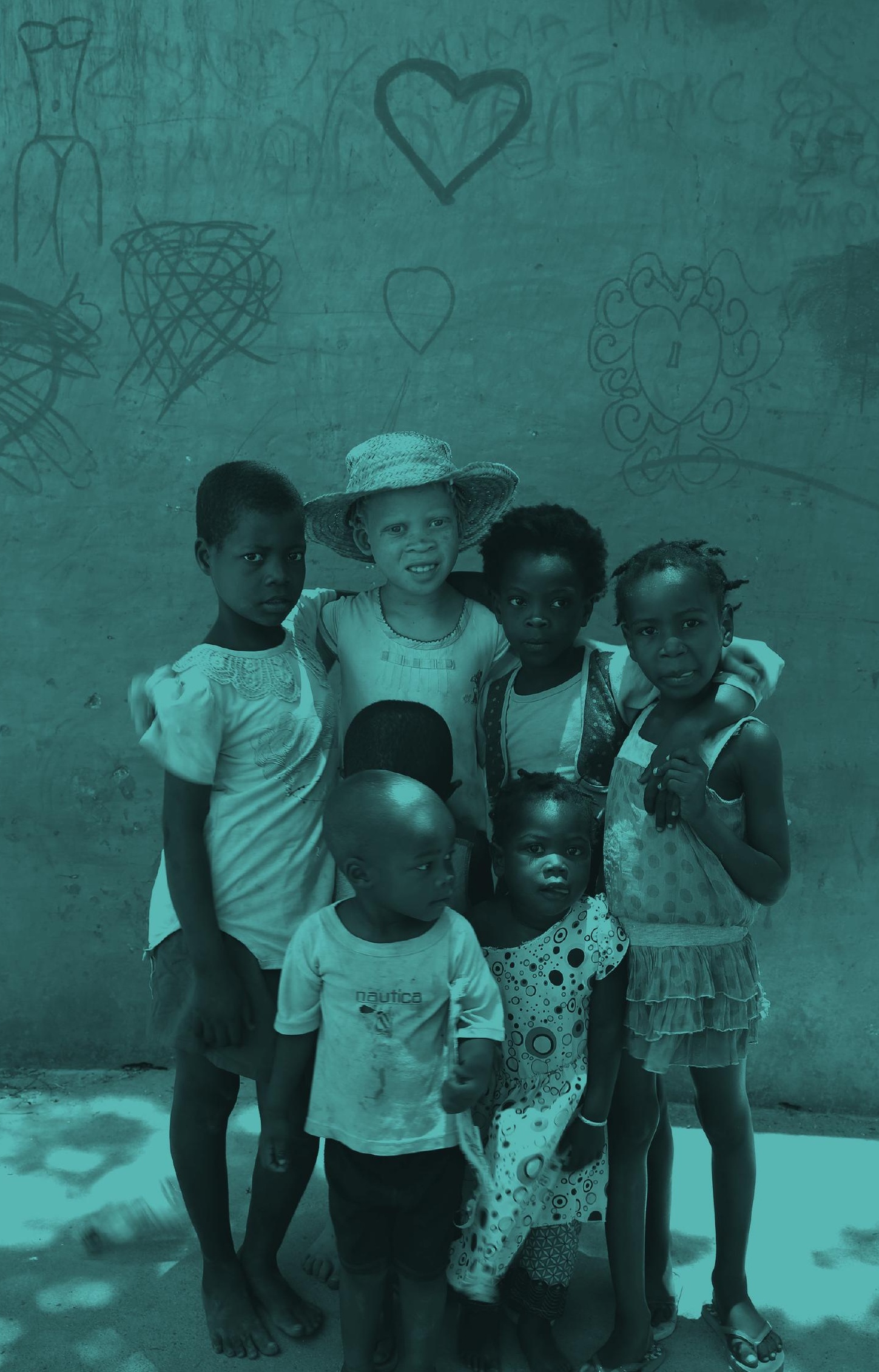




\section{ILHA DE MOÇAMBIQUE: PERFIL SOCIOLÓGICO}

Momade Ali

\section{INTRODUÇÃO}

Este artigo resulta da palestra feita no âmbito do Oficinas e visa descrever a evolução sócio-histórica da llha de Moçambique e as respetivas influências, considerando o seu valor patrimonial, consubstanciado na sua inscrição, em 1991, na Lista do Património Mundial da UNESCO, e tendo em vista os desafios da sua preservação.

\section{BREVE CONTEXTUALIZAÇÃO HISTÓRICA}

A interpenetração das duas correntes culturais (a do interior e a costeira, local e continental) é um dos aspetos principais da história da costa oriental da África durante os últimos 2.000 anos, tendo constituído uma nova amálgama, a civilização costeira swahili.

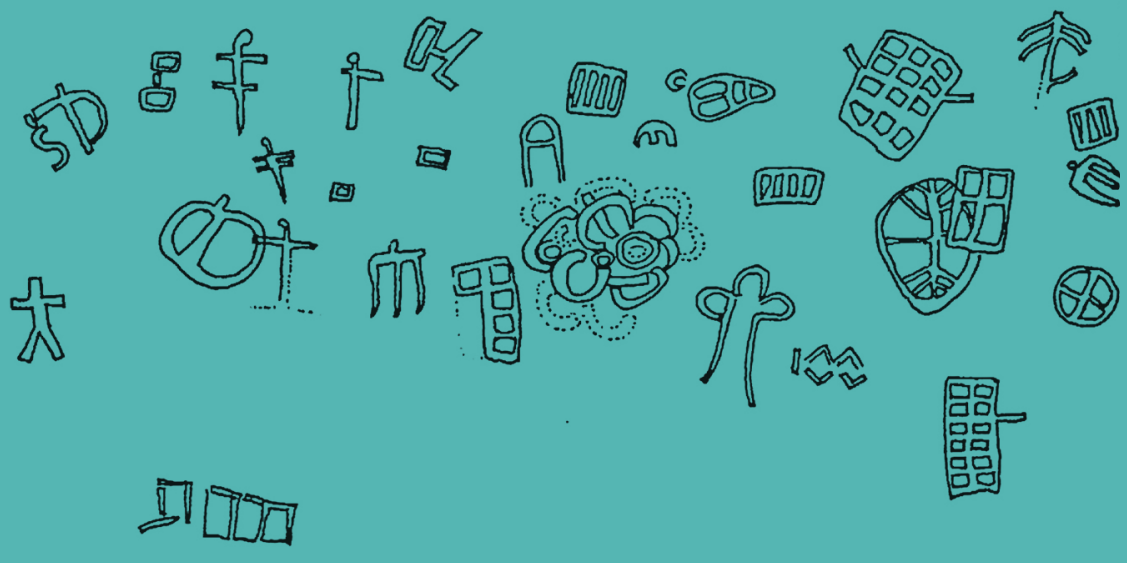


No caso concreto de Moçambique, Mutiua (2015: 234) refere que as migrações de diferentes povos tais como os bantu, originários da África Ocidental, assim como de povos asiáticos e outros do vasto Oceano Índico, de europeus e ainda dos nguni, provenientes da região da atual África do Sul (também conhecidos como mfeqane), marcaram o panorama demográfico e social da costa norte do país e influenciaram os processos políticos e económicos, culturais e religiosos da região entre os finais do século XIX e princípios do século XX.

Pode, então, afirmar-se que a matriz histórica e sociocultural da llha é fundamentalmente resultado dessas dinâmicas locais, regionais e globais que se condensam em movimentos migratórios impulsionados pela necessidade de sobrevivência, incluindo o comércio e a exploração de recursos como o ouro, o marfim, a borracha e, mais tarde, o tráfico de escravos. Os wak-wak, proto-bantu, ou khoi-san, refere Mutiua, foram os povos que interagiram com os primeiros imigrantes bantu que chegaram à região entre 3000 a.C. e 1100 d.C.

No início do século XVII, uma nova onda migratória vinda da região central de África, trouxe os maravi, os quais conquistaram a região através de violentos ataques militares, impondo-se sobre os restantes habitantes, passando a controlar o comércio a longa distância que ligava o hinterland ao Oceano Índico, até ao início do século XIX. Na primeira metade do século XIX, fatores ecológicos, políticos e económicos forçaram os ngunis a um processo migratório designado mfeqane, considerado o maior fator de reconfiguração política, demográfica, social e linguística na região (Mutiua, 2015: 235-238).
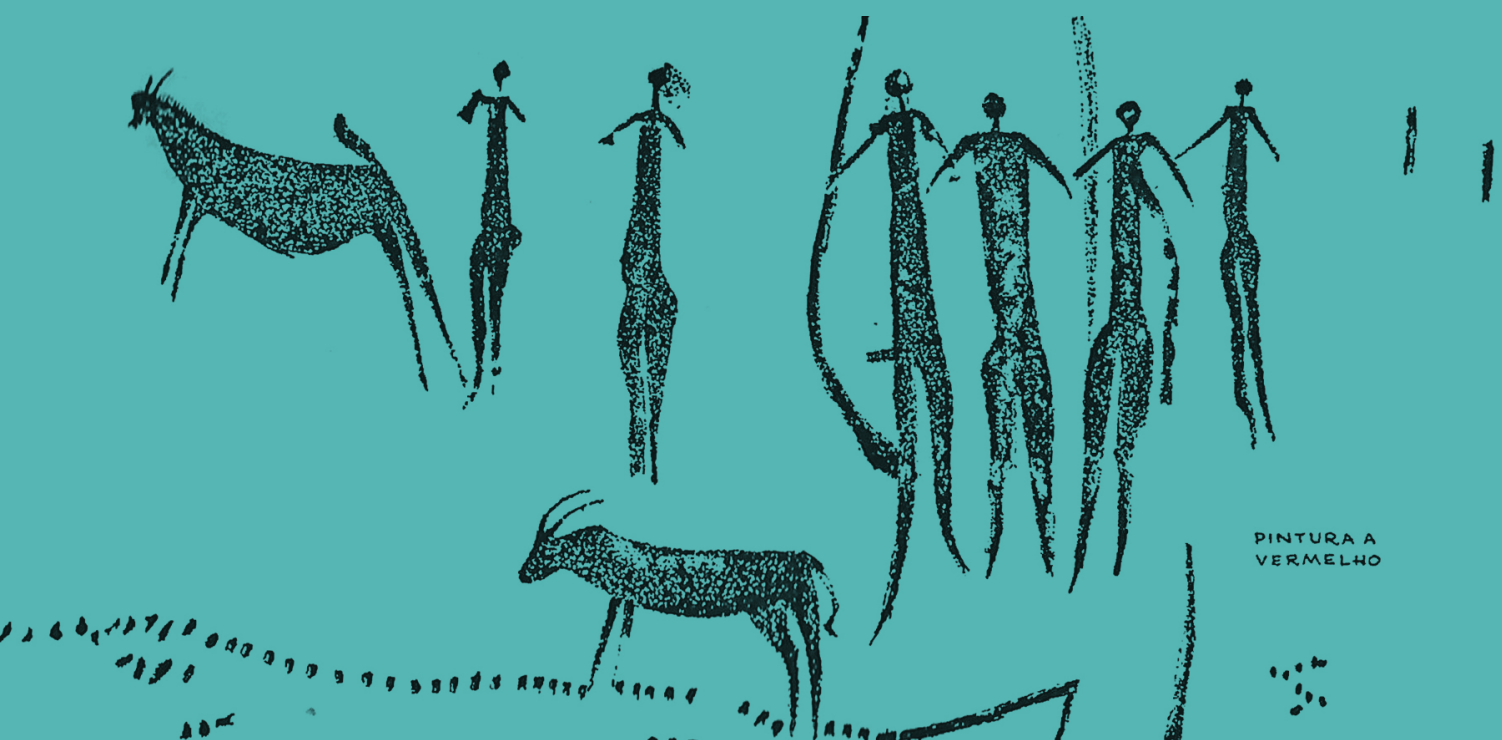


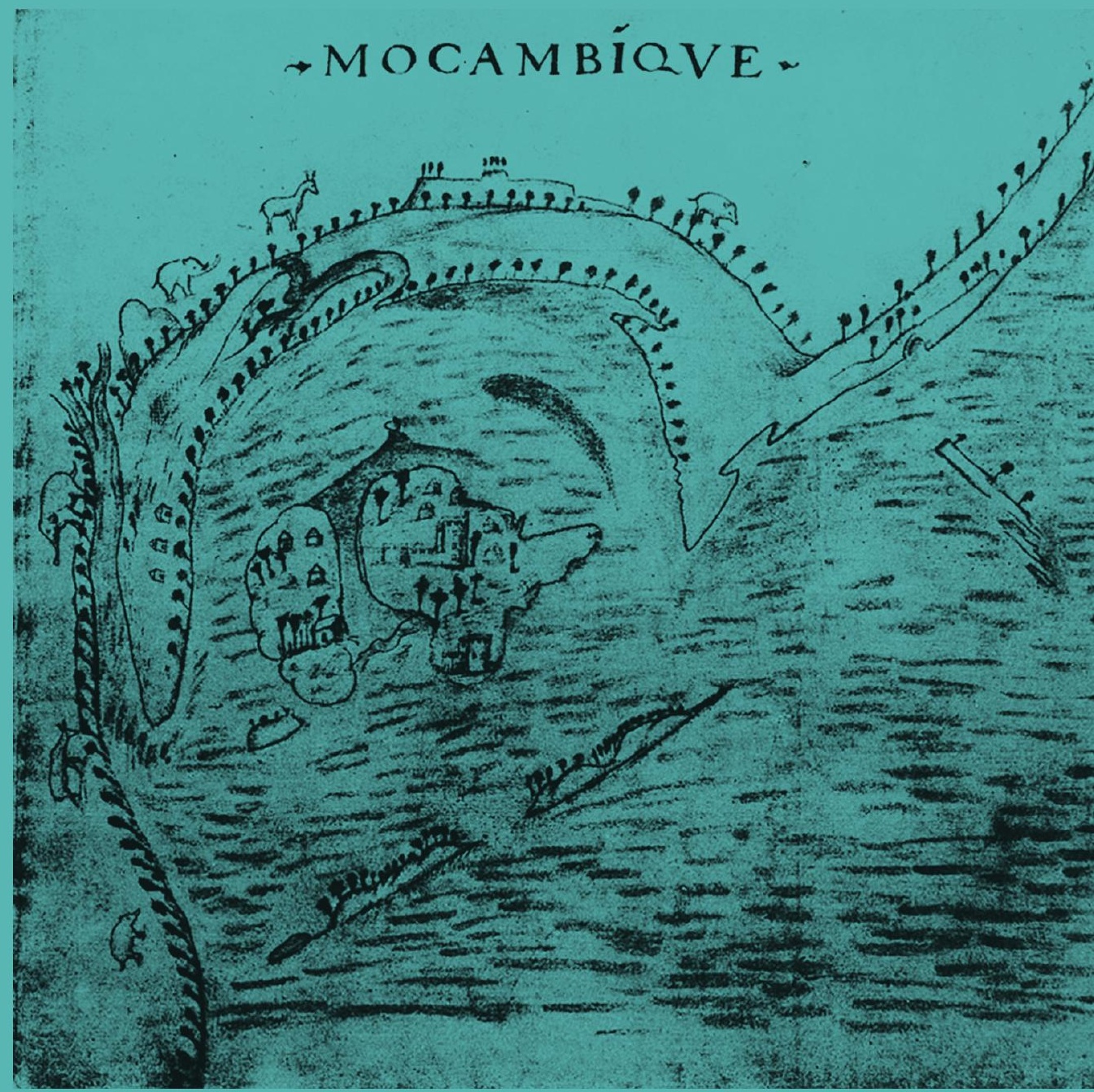

A chegada dos Portugueses, em 1498, chefiados por Vasco da Gama, teve também um impacto significativo na organização política, económica e social na região, favorecendo, por exemplo, a concentração dos principais entrepostos ou assentamentos comerciais sob o controlo dos swahili no norte de Moçambique. Angoche e a Ilha de Moçambique foram, até o século XIX, os principais centros do Islão, através dos emigrantes das cidades swahili de Quíloa e Zanzibar, movidos por razões comerciais, principalmente o comércio do ouro. 


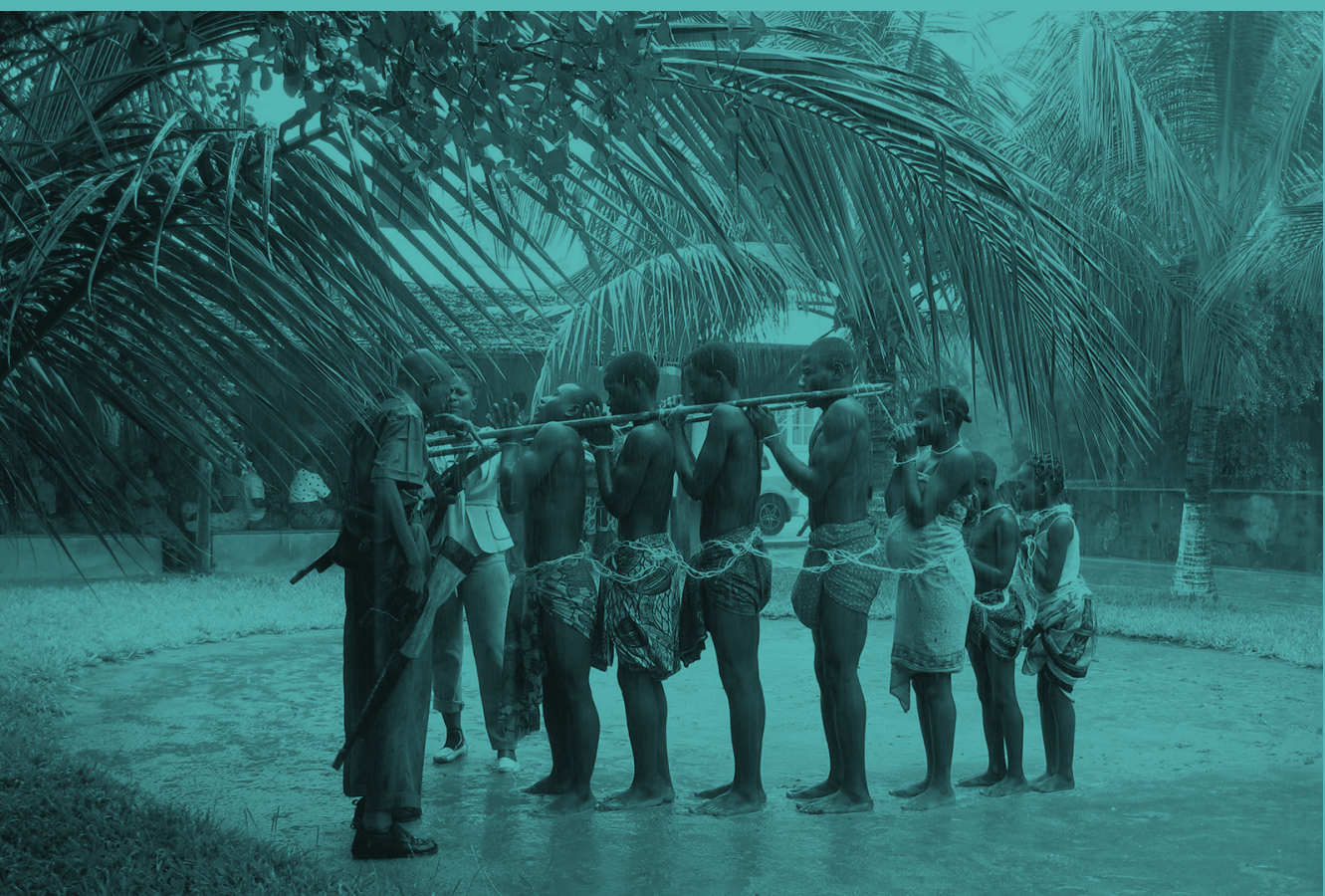

O comércio de escravos tornou-se devastador e significativo durante os séculos XVIII e XIX, sendo os principais operadores da região os Franceses, os Portugueses, os Ayao e os Swahili, tendo como principal fonte a makhuwana. Os escravos provenientes dessa região eram exportados para as Mascarenhas, Comores, Madagáscar, Zanzibar, Golfo Pérsico, Brasil e Cuba, enquanto o ouro tinha como principal destino a Índia (Mutiua, 2015).

Para Aurélio Rocha (2000: 111-112), "foram as classes dominantes desses reinos swahilizados que asseguraram, em todo o século XIX, a exportação clandestina de escravos para Zanzibar, Madagáscar e Golfo Pérsico, após a proibição do tráfico em 1836 e, mais tarde, em 1842". Seja como for, ao possibilitar permanências duradouras, as atividades comerciais acabaram por estabelecer novas estruturas sociais e políticas, fazendo emergir na região costeira do norte de Moçambique uma moldura cultural, histórica e patrimonial com influências locais, regionais e continentais. As sociedades litorâneas constituíram-se em sultanatos e xeicados, com influências de Quíloa e do Zanzibar. 


\section{NOVAS DINÂMICAS, NOVOS DESAFIOS}

Insiste-se na ideia de descrever o perfil sociológico da Ilha sempre em atenção à sua história e cultura, porquanto não se vislumbra outro modo de fazê-lo, tentando definir os desafios que as novas dinâmicas (sociais, políticas e económicas) impõem a esse território e à sua população.

Devido à sua peculiaridade e ao seu valor histórico e cultural, a Ilha de Moçambique foi inscrita, em 1991, na Lista do Património Mundial da UNESCO. Portanto, de acordo com Omar e Júnior, é necessário reconhecer diferentes tipos de bens patrimoniais na Ilha, marcados por processos de constituição e de exclusão, que hoje tornam bastante complexa a definição e preservação do património. A própria linguagem, anotam os autores, regista essa segregação através do idioma, "reservando o português para designar o material construtivo (pedra e cal) da cidade portuguesa, e o emakhuwa [...] para designar a cidade cuja ocupação começou com os escravos que vinham trabalhar na construção da Cidade de Pedra e Cal" (Omar e Júnior, 2015: 5). Estes processos "remetem às demarcações sociais que hoje definem também a institucionalização do património da Ilha, entretanto sem um aprofundamento dos significados nesse processo institucional" (idem, 2015: 57). Do ponto de vista sociológico, acrescentam, a inscrição da Ilha na Lista do Património Mundial, assim como os respetivos esforços da sua conservação e preservação, enfrenta uma herança histórica da divisão espacial pautada pela segregação, que correspondeu a uma "autêntica clivagem socioeconómica e cultural desde o período colonial, visto que a cidade de macuti, por exemplo, sempre foi [e continua] uma zona com um nível social e económico vulnerável em relação à [cidade de Pedra e Cal], facto que mesmo nas atuais políticas [...], torna difícil encontrar mecanismos de gestão global." (2015: 8). Esta será a primeira realidade a superar em qualquer tentativa de redescoberta, conservação e usufruto das riquezas (históricas, socioculturais e turísticas) da llha. É importante, igualmente, considerar as características da população, relevando a pressão demográfica que o território enfrenta desde as últimas décadas do século passado (Teixeira, 2007). 
As estatísticas de 2012 do distrito da Ilha de Moçambique — que tem uma superfície de $445 \mathrm{Km}^{2}$ e uma densidade de 287,7 hab./ $\mathrm{Km}^{2}$ apresentam-nos os seguintes dados demográficos (INE, 2012):

\begin{tabular}{|c|c|c|}
\hline TOTAL & 52.962 & \\
\hline Grupos & Número & $\%$ \\
\hline Mulheres & 27.114 & 51.2 \\
\hline Homens & 25.848 & 48.8 \\
\hline $0-4$ anos & 8.450 & 16 \\
\hline $5-14$ anos & 13.873 & 26.2 \\
\hline $15-64$ anos & 28.233 & 53.3 \\
\hline
\end{tabular}

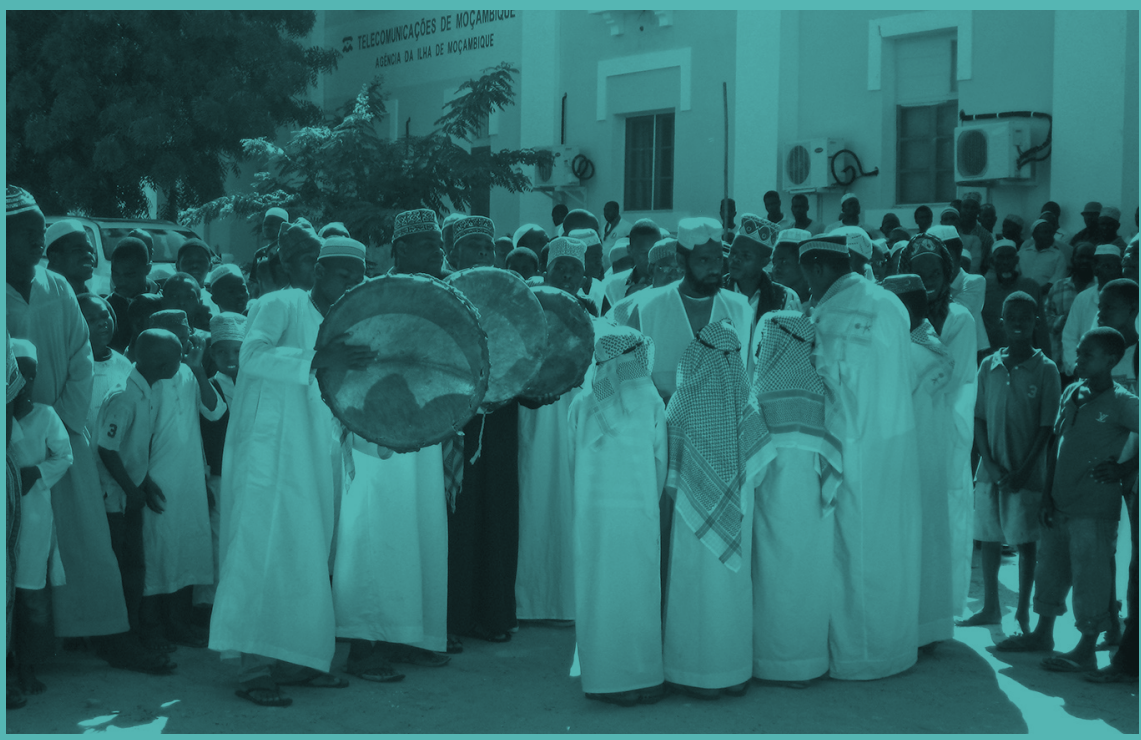

Mais de $90 \%$ da população fala emakhuwa - variante enahara, influenciada pelas línguas árabe e swahili - e professa a religião islâmica. No que diz respeito à alfabetização, compreensivelmente o grupo etário dos 15-19 anos, com 34.5\%, tem a menor taxa de analfabetismo, e o grupo dos mais de 60 anos a maior, com $70.8 \%$ (INE, 2012: 15). 


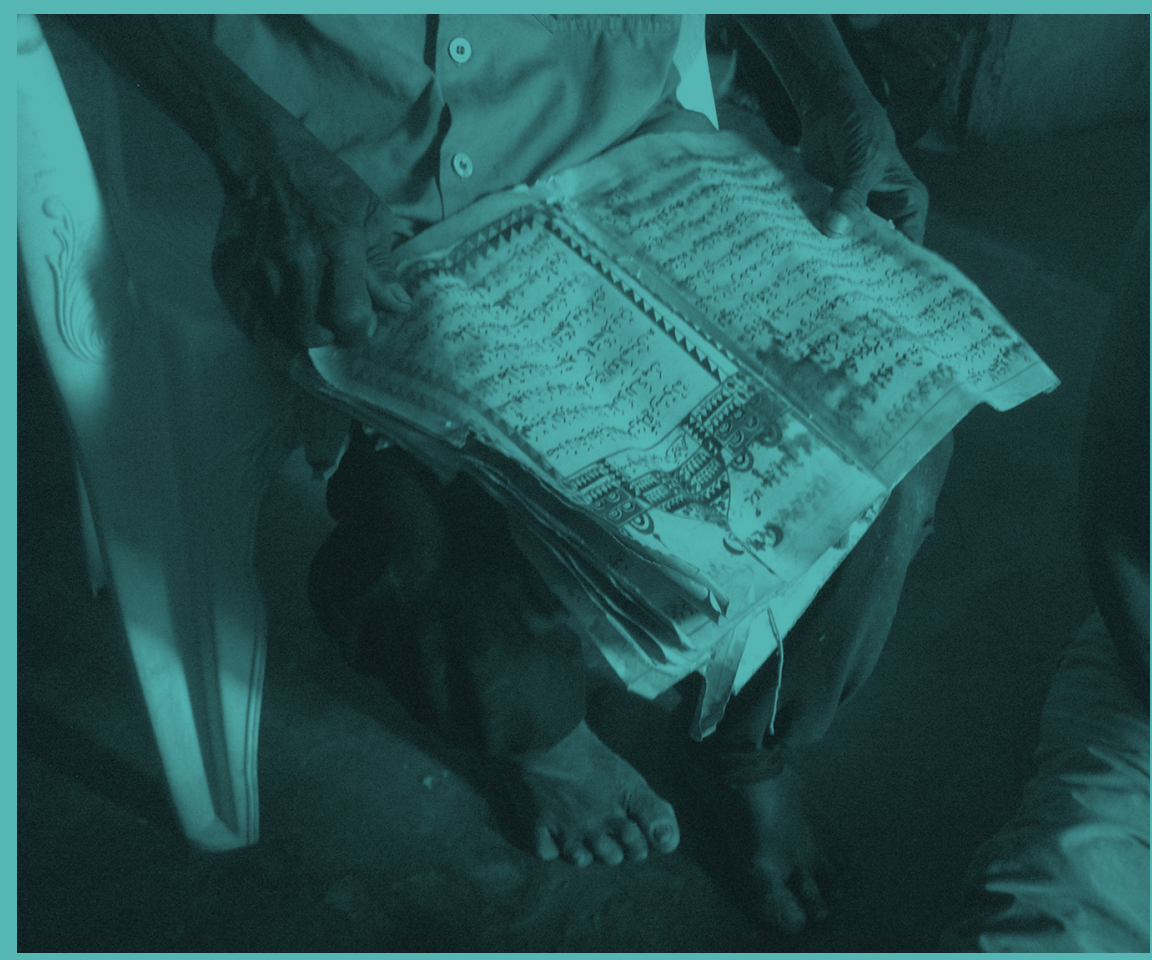

Por entre os indicadores de bem-estar, é relevante destacar que, no que diz respeito ao sistema construtivo das habitações, as casas de adobe e/ou paus maticados representam $63.6 \%$ do total, sendo que $76.8 \%$ têm cobertura de capim, colmo ou macuti; e que em relação a bens duráveis, 38\% dos agregados possuem rádio, $9.3 \%$ televisão, $19.2 \%$ bicicleta e $54.5 \%$ não possuem nenhum.

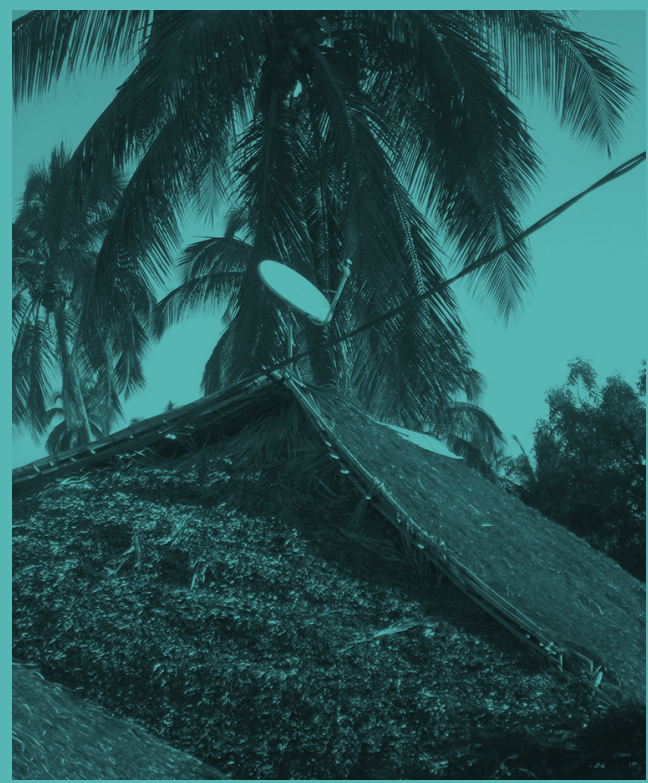


Em termos de indicadores sociodemográficos, particularmente:

Em 2011, o setor educativo público tinha no território um total de 14 escolas primárias do $1^{\circ}$ grau e 11 do $2^{\circ}$ grau. Havia também 4 escolas secundárias públicas do $1^{\circ}$ ciclo e igual número de privadas, 4 escolas secundárias públicas do $2^{\circ}$ ciclo e igual número de privadas. Com a abertura da Faculdade de Ciências Sociais e Humanas, em 2016, a UniLúrio (que, em 2011, ali criara o Centro de Estudos e Documentação da Ilha de Moçambique) tornou-se na primeira instituição de ensino superior a instalar-se na Ilha.

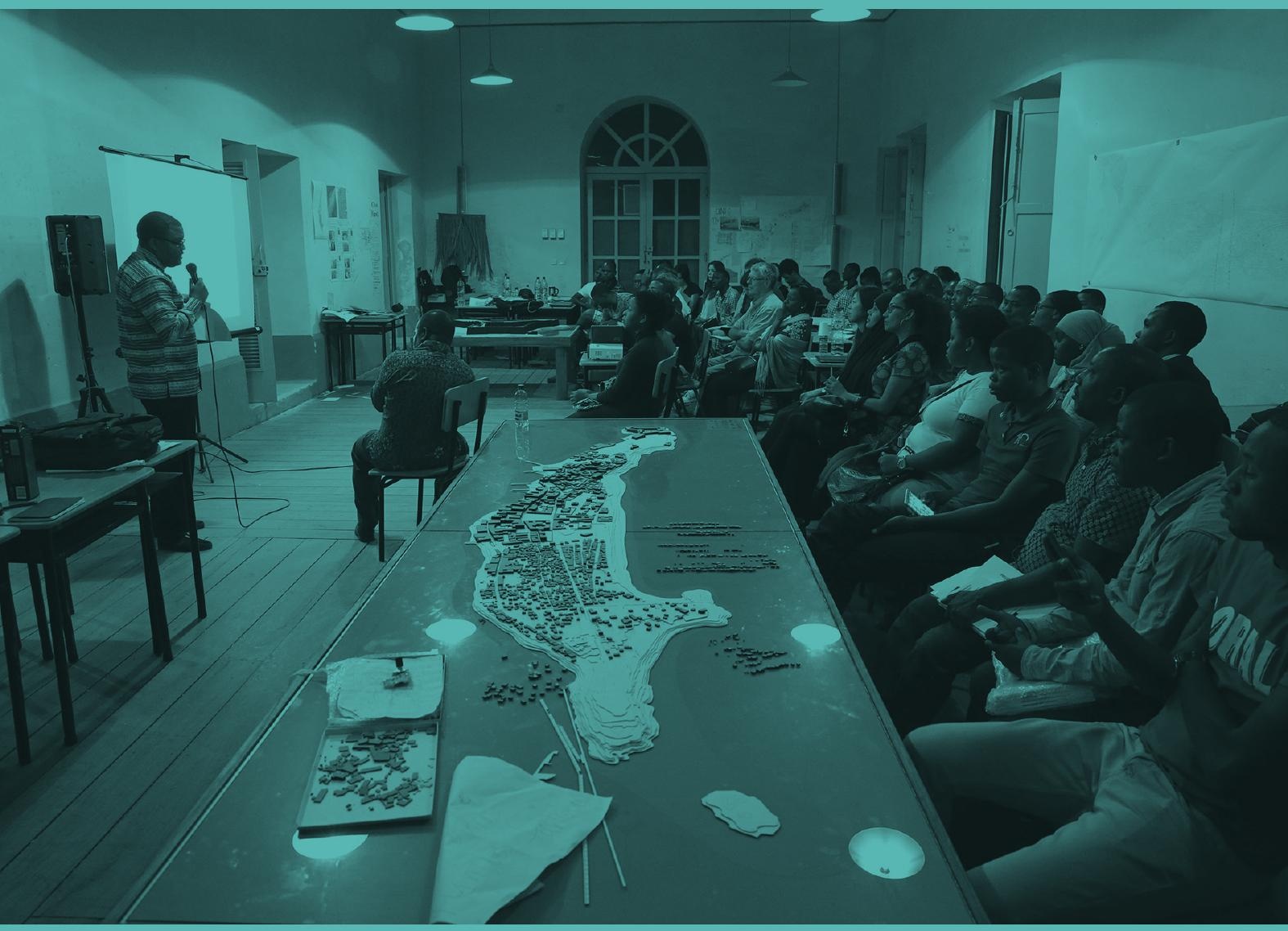




\section{CONSIDERAÇÕES FINAIS}

Concluindo este breve retrato sociológico da llha, cabe invocar a síntese de José Pimentel Teixeira (2007), que descreve o perfil sociológico do distrito da llha de Moçambique como de predominância linguística do emakhuwa nas relações de sociabilidade locais, prevalência da religião islâmica, e de acentuado crescimento demográfico e urbanístico.

Contudo, e com base nos dados de bem-estar, constata-se que, em geral e à semelhança do país, o distrito da Ilha de Moçambique vive uma situação de pobreza, destacando-se fatores que contribuem para as difíceis condições de vida que nela residem, em especial a elevada densidade populacional, as características climáticas (que facilitam a propagação de várias doenças), e "uma economia limitada em todos os seus sectores, que não permite a criação de empregos e que, consequentemente, leva à impossibilidade de os agregados familiares possuírem recursos suficientes e satisfatórios" (Patrão e VasconcelosRaposo, 2011: 152). Para além do comércio, a população vive da agricultura, da pesca, da pecuária, da indústria e do turismo.

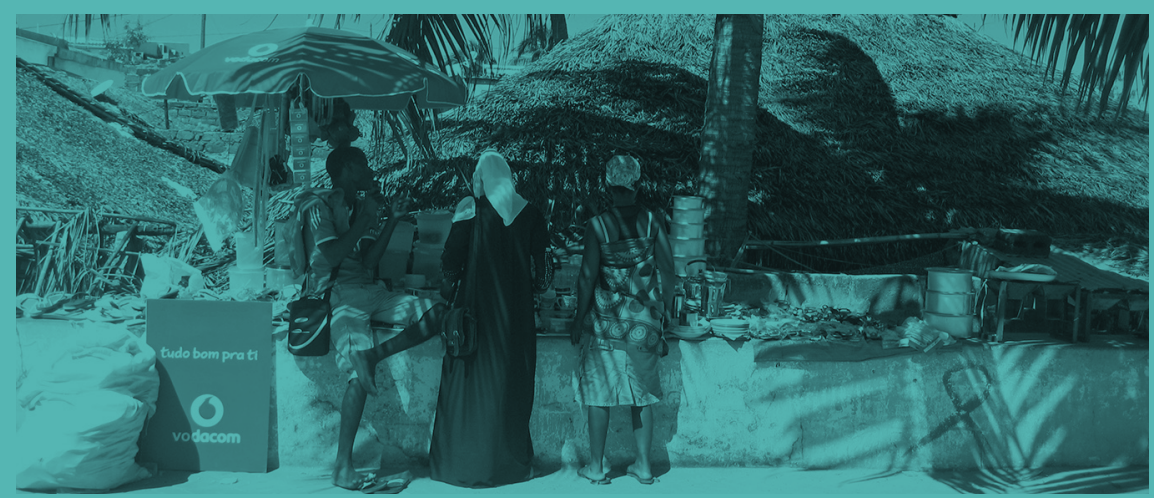

Por tudo isso, as intervenções sociopolíticas não se deverão resumir em ações paliativas, superficiais ou de contingência, mas sim integrar um substrato institucional com efeitos de médio e longo prazo na educação e cultura, através da formação de uma nova geração de profissionais qualificados, capazes de oferecer soluções de desenvolvimento local e comunitário. 


\section{REFERÊNCIAS BIBLIOGRÁFICAS}

Instituto Nacional de Estatística (2012), Estatísticas do distrito da Ilha de Moçambique. Governo de Moçambique: INE.

MUTIUA, Chapane (2015), "O Norte de Moçambique entre os séculos XIX e XX" in Teresa Cruz e Silva et al. (orgs.). Comunidades Costeiras: perspectivas e realidades. Maputo: CESAB.

OMAR, Lúcia; JÚNIOR, Euler (2015), "Património cultural e memória social na Ilha de Moçambique", Revista CPC, 18, 4-28. São Paulo.

PATRÃO, Ana Luísa; VASCONCELOS-RAPOSO, José (2011), "O Estado de Saúde da Ilha de Moçambique: Uma análise comparativa dos indicadores de saúde da população". Cadernos de Estudos Africanos, 21, 147-161.

ROCHA, Aurélio (2000), "Os reinos afro-islâmicos da costa" in Carlos Serra (dir.), História de Moçambique, vol.1. Maputo: Imprensa Universitária. 111-126. ${ }^{1} 1993$.

SHERIFF, Abdul (2011). "A costa da África Oriental e seu papel no comércio marítimo" in Gamal Mokhtar (coord.), História Geral da África. II. A África antiga. São Paulo/UNESCO: Ática/Paris. ${ }^{1} 1983$.

TEIXEIRA, José Pimentel (2007), Conteúdos comunitários na área da llha de Moçambique face a projectos de desenvolvimento. Relatório de Consultoria para o Banco Africano de Desenvolvimento. 
9

1. 13

50

Sunt 25

(1) 1 .

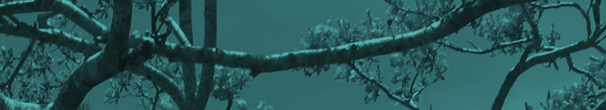

$-\infty-A$

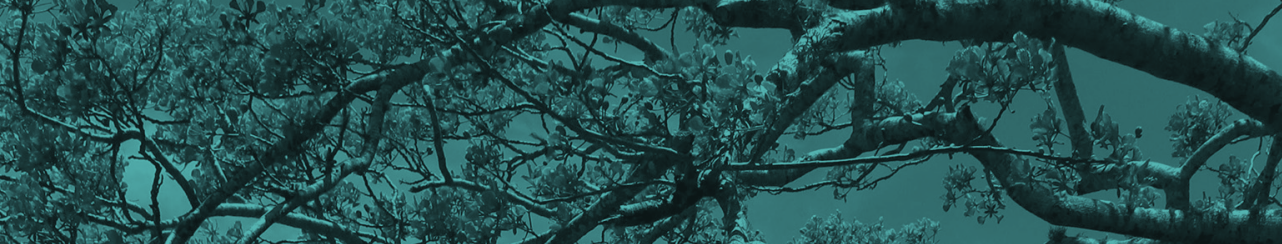

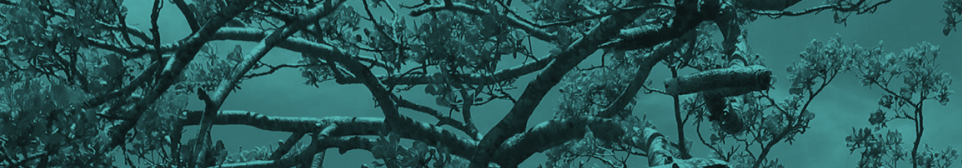

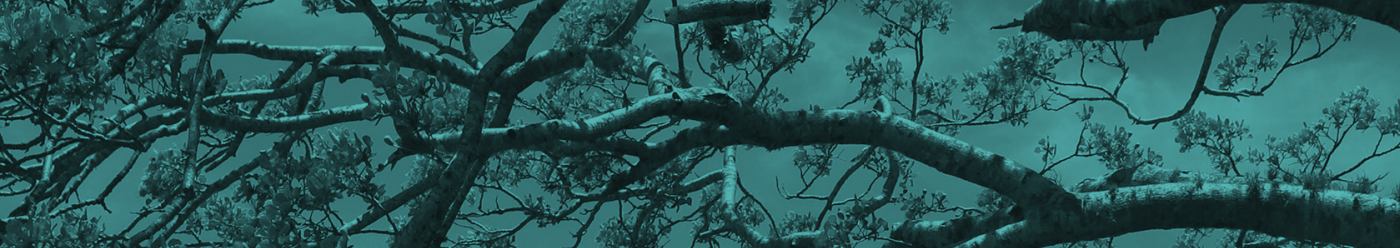

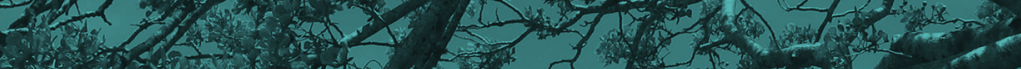
1. 1. 41 in

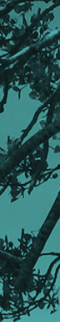
1. 15 $1,-\infty$

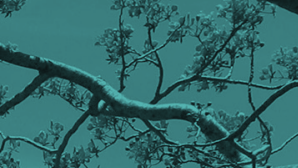
1.t.

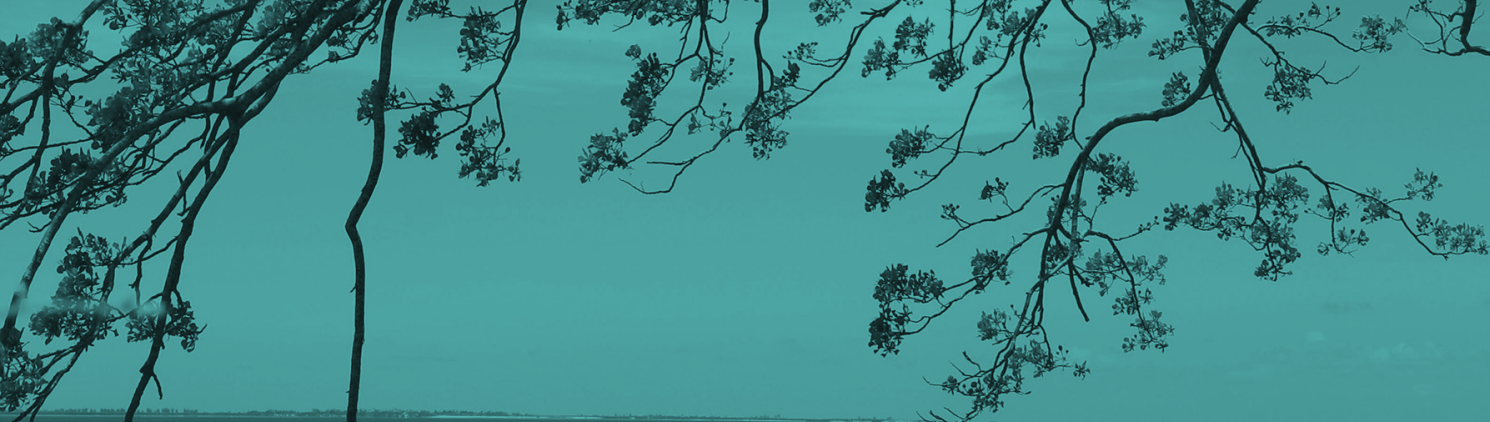

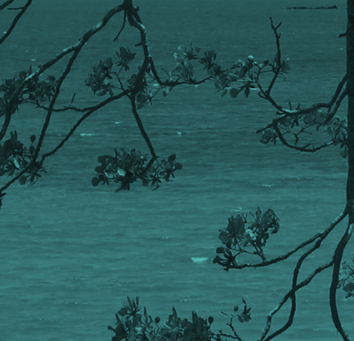

(1) $\int_{1}$ 

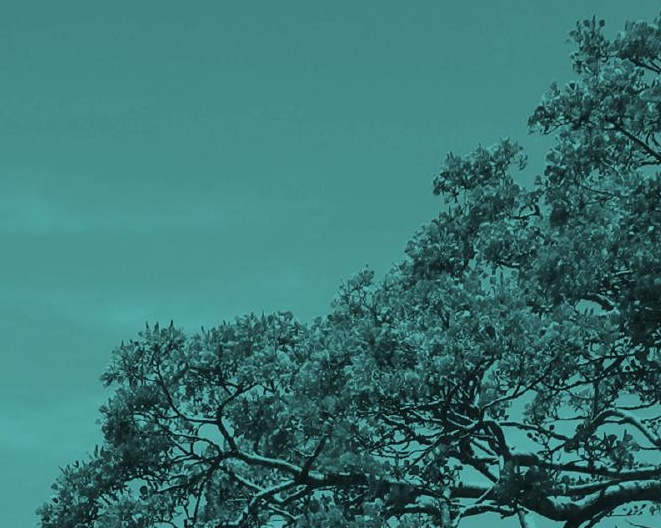
(1)

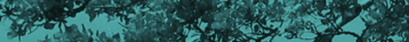

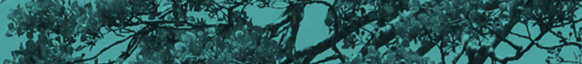

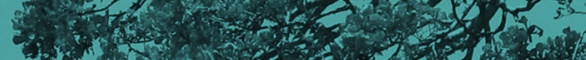

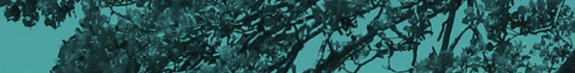

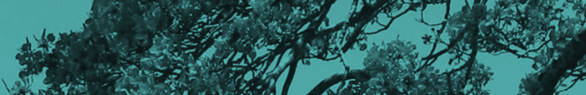
H. का

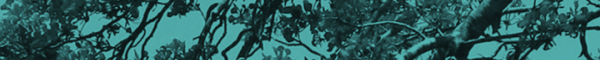
of

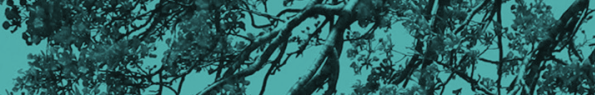
*

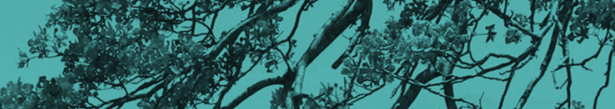

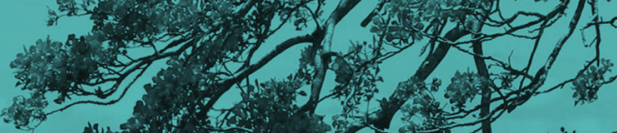
(1) - 1 (4)

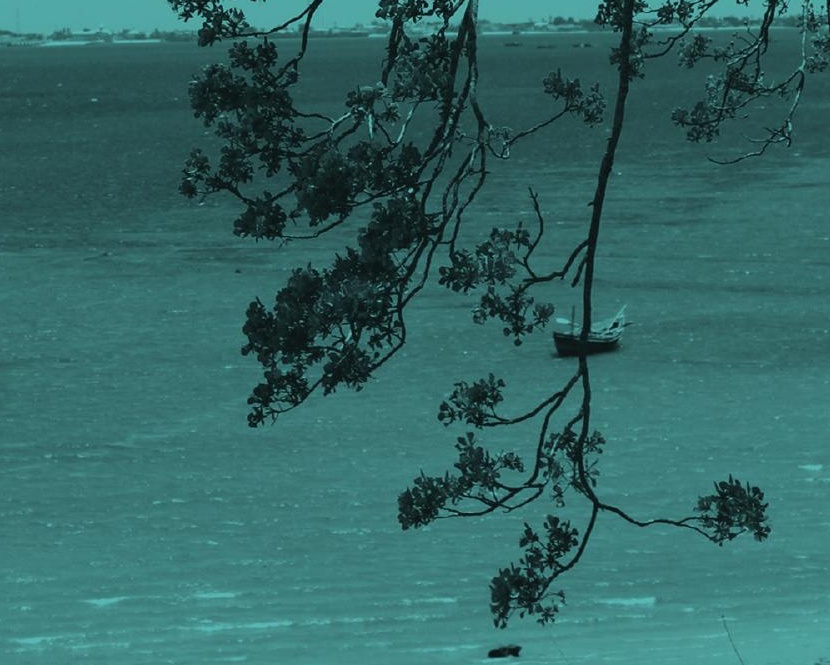




\title{
ILHA DE MOÇAMBIQUE SALUBRE E FRESCA EM TEMPO DE ALTERAÇÕES CLIMÁTICAS
}

\author{
João Vaz
}

\section{INTRODUÇÃO}

O património natural da llha de Moçambique está em risco e declínio. Por um lado, as preocupações do património concentram-se na recuperação de imóveis, por outro, evidencia-se um certo desinteresse pelos valores da conservação da flora e da fauna nativas.

Tanto em terra como no mar esses sinais de perda são evidentes, em especial naquilo que o visitante atento observa facilmente, porque está perto e é visível: há muito lixo nas praias, desde garrafas de plástico até restos de redes mosquiteiras abandonadas; as motos de água, ao fim de semana, afugentam um capital natural muito valioso, a vida marinha de proximidade, desde as baleias que se aproximam do pontão até às pessoas que desejam apenas dar um mergulho; os pequenos peixes tropicais que circundam a embarcação afundada no pontão são capturados por pescadores amadores; a erosão começa a sentir-se na contracosta, o mar bate com mais força e os muros de contenção estão a colapsar. Falta um plano para rearborizar a Ilha, substituindo árvores envelhecidas precocemente por sucessivas podas mal conduzidas, com destruição da copa; para além da situação da salubridade e da gestão de resíduos, onde existem esforços visíveis de limpeza da llha, muito do lixo continua a ser enterrado na areia e não existe valorização material. Os desafios são imensos e só serão ultrapassados se a sociedade civil se mobilizar e pressionar o poder político a agir de forma mais persistente.

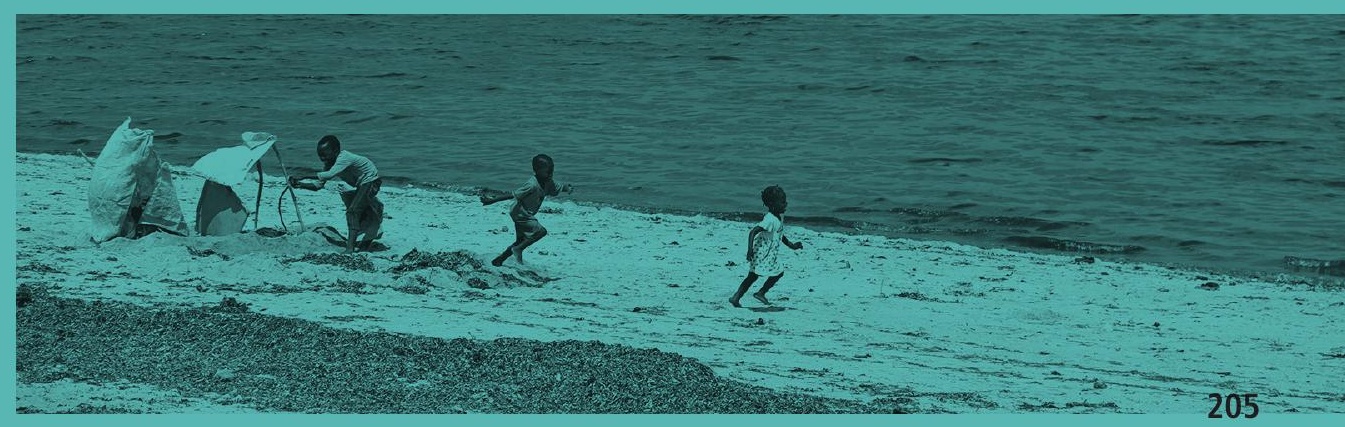




\section{2. ÁRVORES QUE VALORIZAM A ILHA}

Há poucos locais no mundo onde a beleza patrimonial seja tão reconhecidamente magnífica, coexistindo com uma riqueza natural tão diversificada. Começar a valorizar as árvores da llha é "classificar as maiores árvores de interesse público é evidenciá-las, protegê-las e estimular outros a preservar as árvores mais antigas, que carregam a história e a memória dos que com elas conviveram ou convivem." (Lage, 2008a: 35).

É necessário explicar à população o seu valor e interesse, começando pelas escolas. E aqui um parêntese para afirmar a ausência de conhecimento nesta área: as crianças e os próprios jardineiros não sabem identificar as árvores pelo nome e desconhecem qual a sua importância ecológica. As árvores são mal entendidas: sujam, ameaçam as casas, podem cair, são maltratadas. Essa evidência ganha força quando falamos com os decisores sobre as podas das árvores dos espaços urbanos que estão mal informados e continuam a podar radicalmente as árvores, destruindo a copa, secando-as a prazo.

Parece estar esquecida a absoluta importância das árvores em climas tropicais, amenizando a temperatura, emprestando sombra e contribuindo para a valorização estética dos espaços urbanos. Os técnicos precisam de apropriar-se desta ideia e de obter formação sobre a manutenção de árvores em espaços urbanos. As árvores devem ser podadas com técnica, ficando com parte dos seus ramos prontos a trabalhar, purificando o ar e oferecendo uma refrescante sombra quando o sol queima.

Falta um programa de substituição e plantação de novas árvores. A ameaça à ideia de plantação de árvores é evidente na observação dos espaços das caldeiras das árvores: são tapados com cimento, decerto por facilitismo, talvez por insensibilidade. É preciso criar ainda programas de sombra natural para a cidade de macuti, onde quase não há sombras e as casas forradas a chapa de zinco aquecem muito, com todos os problemas sanitários daí decorrentes. Contudo, antes de se plantar uma árvore deve avaliar-se o espaço que lhe queremos destinar, procurando plantar árvores locais. Citando um especialista na matéria, "As árvores sabem como interagir com equilíbrio com as demais árvores, arbustos e ervas do tecido vegetal local, estão bem integradas há milhares de anos" (Lage, 2008: 42). 


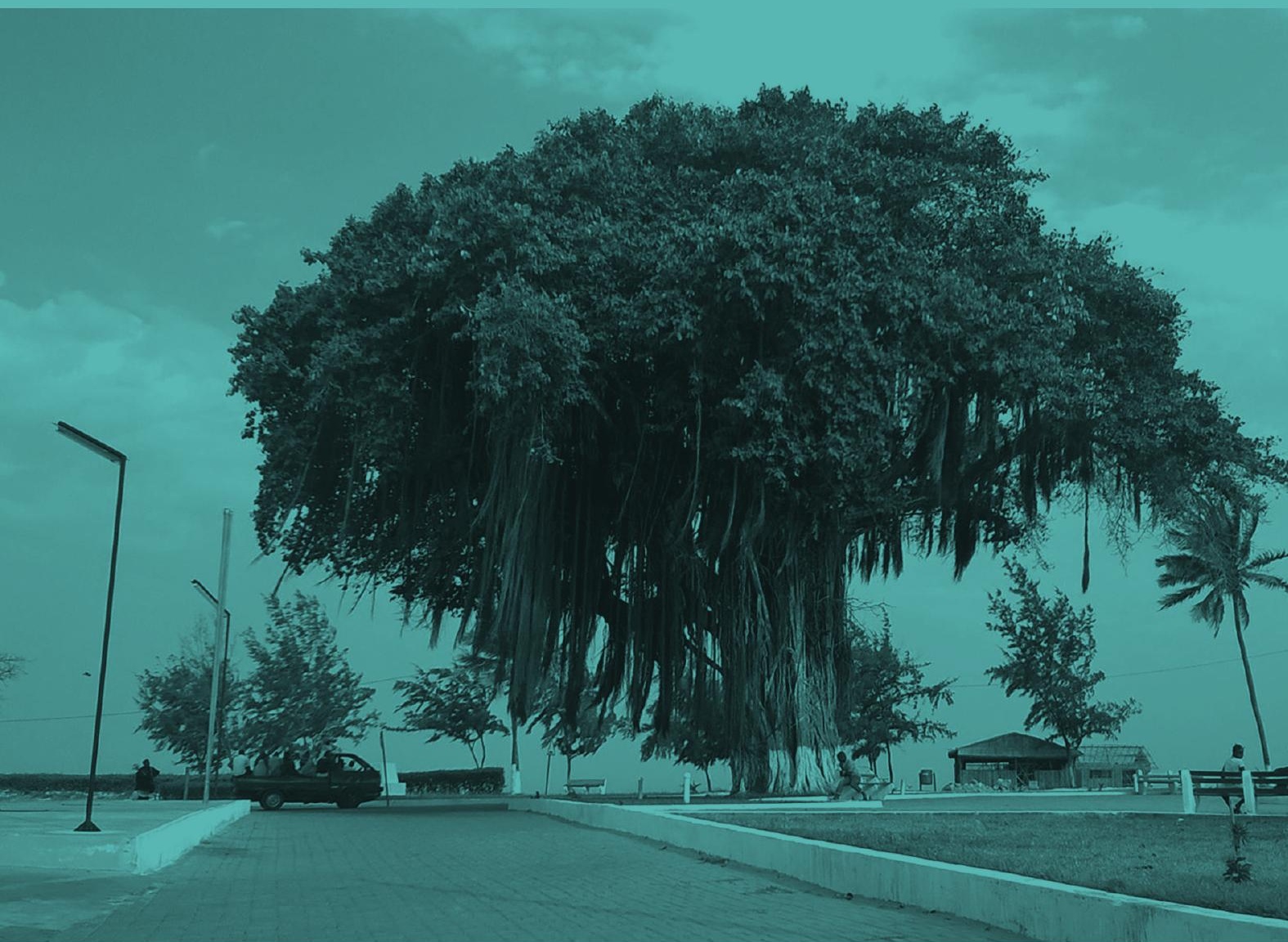

O biólogo Jorge Paiva, em A Relevância das Árvores das Artérias Urbanas, refere-nos que "uma cidade além de ser uma parcela integrada da paisagem, não deve constituir apenas um agregado de blocos de betão [pedra] separados por arruamentos asfaltados [cimentados, impermeabilizados], sem quaisquer espaços verdes, nem árvores ou arbustos nas respetivas artérias" (apud Lage, 2008: 42). Sabemos ainda que o clima está a mudar e as árvores são uma parte importante da solução, mitigando as ondas de calor, contribuindo para que a temperatura nos espaços urbanos seja mais amena. 


\section{FECALISMO, SALUBRIDADE E LIMPEZA DE PRAIAS}

O fecalismo a céu aberto nas praias da llha é considerado a maior ameaça à qualidade das praias. Apesar desta triste realidade persistir há dezenas de anos, as soluções não têm funcionado bem. Os sanitários são poucos, de má qualidade construtiva e muito insalubres. Tudo se resume a maus projetos. A abordagem que defendo para os sanitários, e a eliminação da necessidade da população usar a praia como casa de banho, passa por duas medidas simples, mas difíceis: privatizar os balneários e demolir os existentes. As pessoas estão dispostas a pagar 2 a 5 meticais por uso para ter condições de higiene, com banho e água salubre. Sabemos ainda da dificuldade e maus resultados dos municípios assumirem a gestão direta de equipamentos, pois tudo funciona melhor se houver geração de receita e gestão privada dos equipamentos e, ainda assim, é necessária fiscalização, empenho, apoio técnico e uma enorme persistência até que se possa verificar uma gradual mudança de hábitos.

A limpeza das praias enferma de uma incompreensão sobre o que é limpar e o que é lixo que precisa de ser limpo. Hoje, enterra-se o lixo na praia. As pessoas encarregadas da limpeza diária das praias (cerca de 13 pessoas, 6 dias por semana das 5 h00 às 9h00), gastam muita energia, tempo e dinheiro para esconderem temporariamente o lixo debaixo da areia. Plásticos (oleados e galões, como se diz na llha), descartáveis (fraldas), latas, roupa, redes mosquiteiras, vidros, calçado, filtros de óleo, pilhas e milhares de outros objetos antropogénicos ficam na praia e no mar. Vão e voltam, andam a pairar à volta da Ilha, de praia em praia, até se desfazerem e persistirem sob a forma de micropartículas poluidoras, envenenando o mar e enchendo o estômago de aves e peixes que, com a sensação de estarem saciados, deixam de se alimentar, causando a morte por subnutrição.

Limpar as praias na llha teria um efeito económico muito sensível. As praias urbanas de qualidade são raras e muito apetecidas. Os turistas ficariam mais dias na llha se tivessem praias limpas, sem plásticos nem excrementos. As autoridades locais não entenderam isto na sua plenitude, talvez por não frequentarem as praias urbanas e não conseguirem compreender os desejos dos turistas e visitantes. 
São necessárias ações de sensibilização na área de gestão das praias, a começar pelos decisores e técnicos, levando-os ao terreno para compreenderem os principais problemas. Importa, por fim, a interiorização de que algas marinhas, folhas e outras formas naturais de vida do Oceano Índico não são lixo. Uma praia cheia de algas na zona intermareal é normal e aceitável. Contudo, muitos decisores julgam que uma praia limpa é aquela que está vazia de algas e plantas, ignorando muitas vezes até o que realmente interessa limpar, isto é, o lixo que é lixo: os plásticos, as garrafas e tudo aquilo que não é natural. Os presidentes e vereadores, os chefes de posto e régulos, são necessariamente aqueles de que mais capacitação necessitam, porque têm o poder direto na influência de práticas e costumes, combatendo de forma mais eficaz a insalubridade do espaço público.

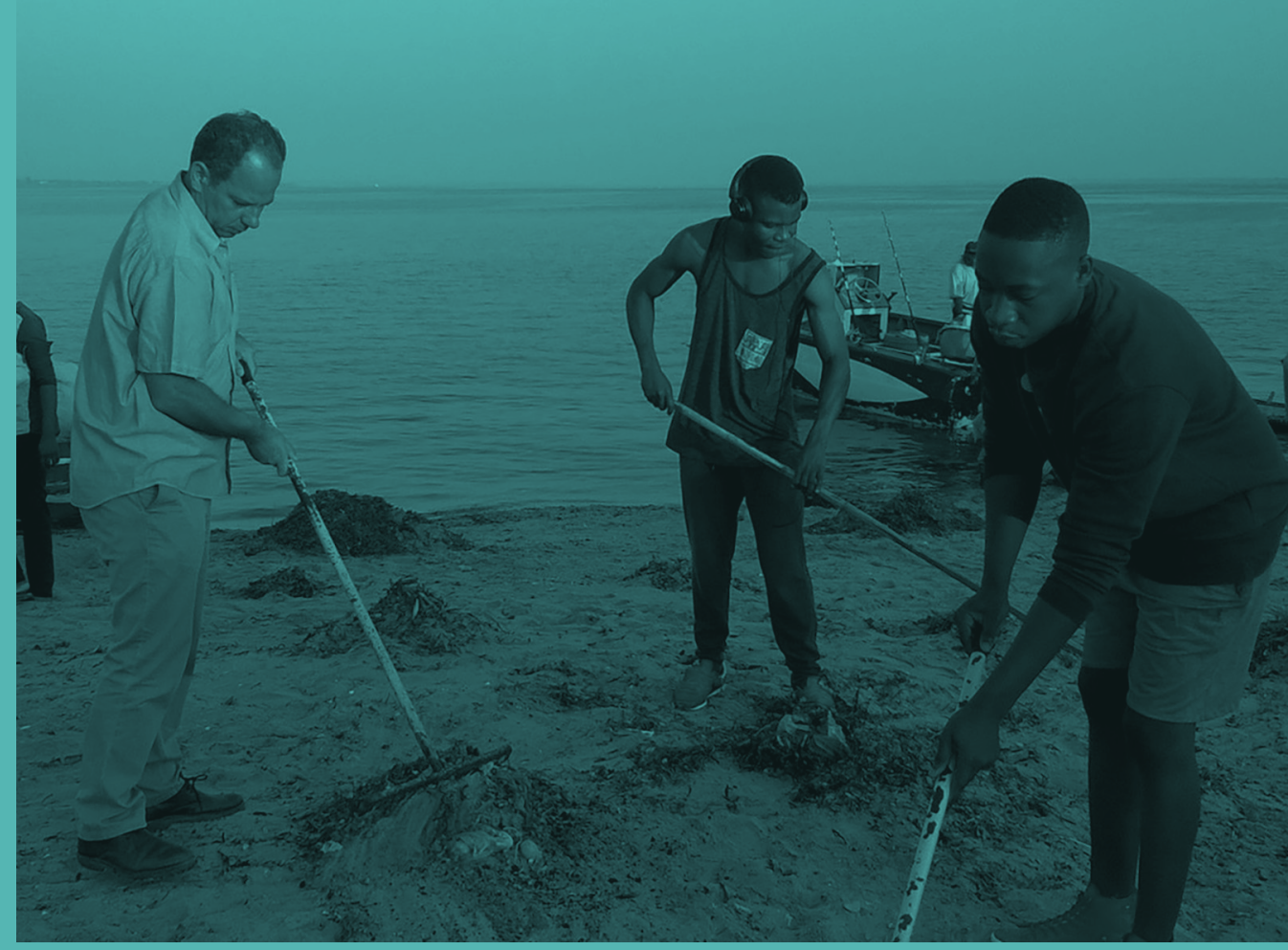


Seria possível ir mais longe na limpeza da llha e do planeta, pagando a quem recolhe lixo pela quantidade e qualidade do que é removido da praia e do mar. A llha poderia ser pioneira neste campo, mais ainda se reaproveitasse esse mesmo lixo para o artesanato, criando uma verdadeira fileira de bens, inovando e dando emprego a muitos jovens desocupados. Tudo isto precisa de ser financiado internamente e externamente. Acredito que haverá forma de o fazer com sucesso, bastará persistir e mostrar à comunidade internacional que a llha é vítima de quem fabrica "fraldas descartáveis, com materiais que não são biodegradáveis, numa lógica onde impera o lucro e não o bem comum" (Vaz, 2014). A este propósito, refira-se que os mergulhadores profissionais da llha se queixam frequentemente da existência de fraldas de plástico agarradas ao fundo do mar, impedindo os corais de respirar e, na prática, asfixiando a base da vida marinha.

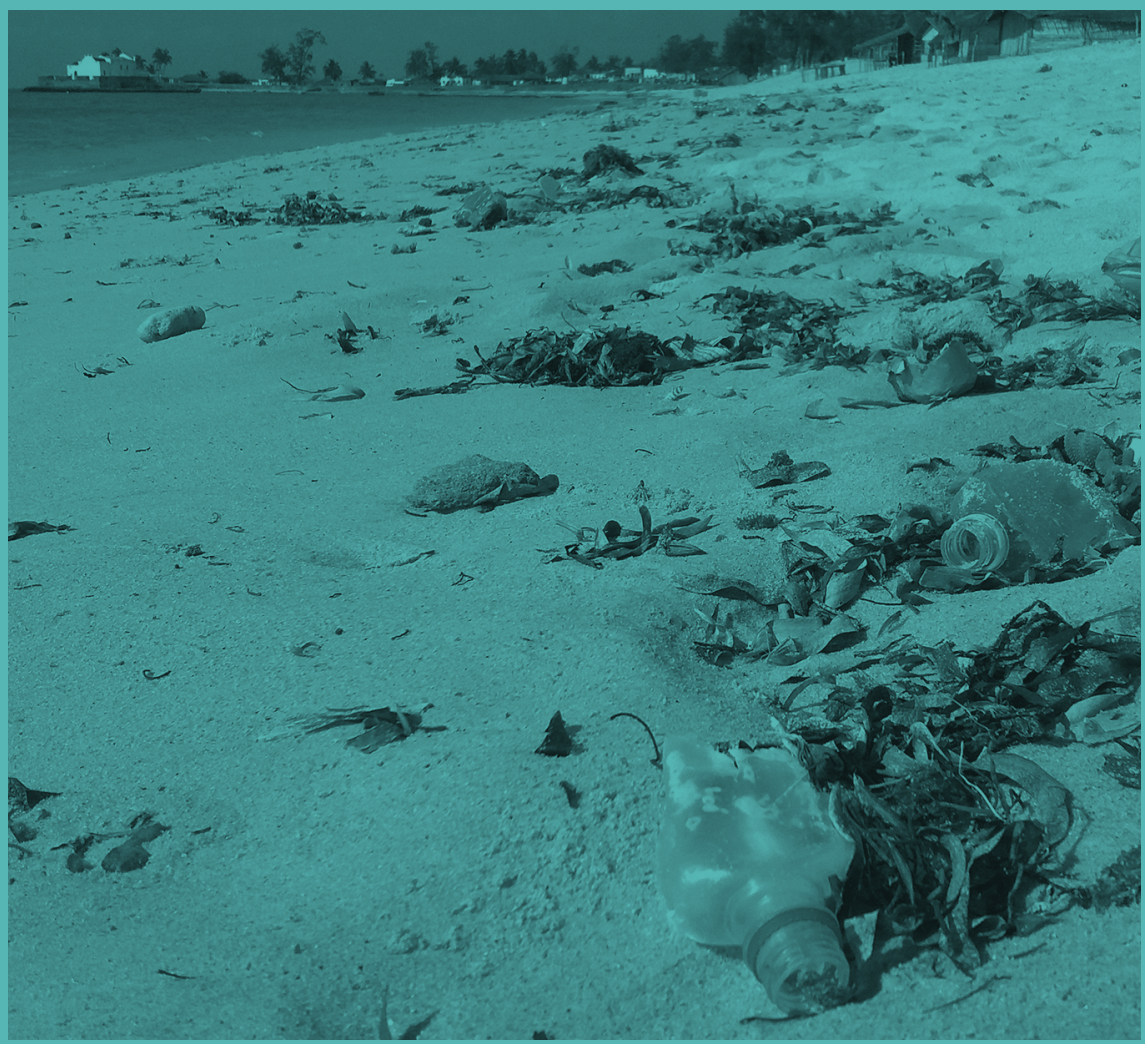




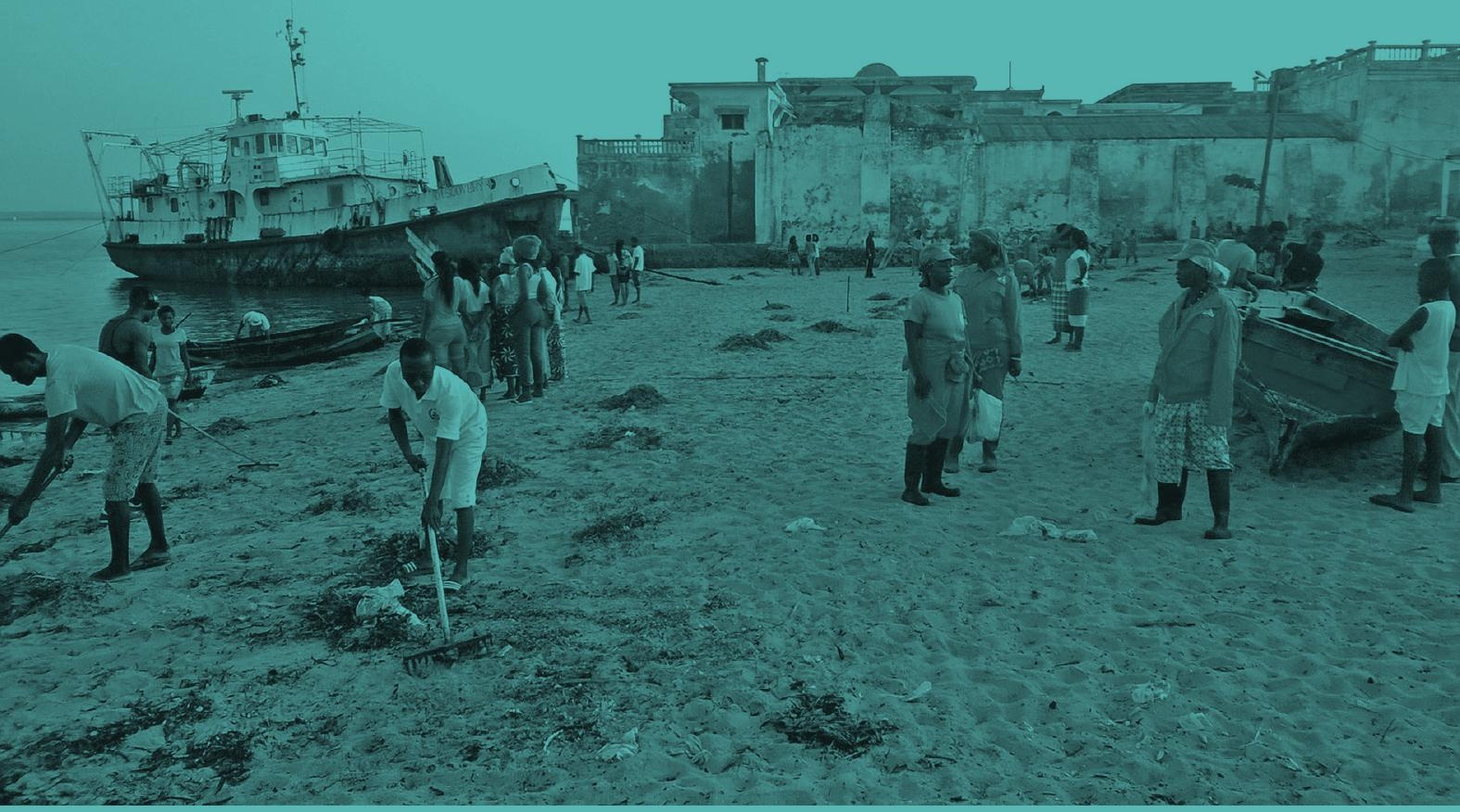

\section{A GESTÃO DE RESÍDUOS}

A salubridade do habitante médio da Ilha é reconhecida, existem preocupações visíveis com a limpeza dos espaços privados. As pessoas começam o dia, às 5h00, a varrer o quintal e a colocar o lixo fora de casa para que este seja recolhido. O espaço privado, em geral, está limpo e bem cuidado. Já o espaço público carece de outra abordagem. Aqui, o lixo é por vezes enterrado em buracos entre as casas, a pedido das pessoas. Varre-se o lixo para o buraco e espera-se que este venha a desaparecer. A parte orgânica, sim, desaparece, mas tudo o resto permanecerá muitos anos. O trator do lixo desvia-se frequentemente da sua rota para despejar resíduos domésticos e comerciais em fundações de futuras casas. Esta realidade, chocante para quem compreende os efeitos indesejáveis na casa e sua salubridade, é adotada na Ilha, sobretudo na parte continental, como prática habitual. O lixo é um fenómeno cultural e daí a sua gestão ter que se adaptar à realidade que encontramos. Contudo, as pessoas têm que ter locais para colocar o lixo, baldes, tambores, contentores, etc., o que não acontece com a frequência e conforto desejáveis. Ninguém anda mais de 200 metros com o lixo para o despejar no sítio certo. Se não encontra sítio, deixa-o em qualquer lugar. Verifica-se, portanto, a necessidade de a llha investir muito mais na recolha primária, nos baldes e contentores, podendo responsabilizar mais as pessoas. 


\section{VISÃO PARA A ILHA}

Na llha há um investimento real na recolha do lixo: o sistema de apito, em que o trator do lixo passa e leva o lixo das pessoas. Funciona bem, mas poderia ser mais ambicioso e abrangente, contando com a colaboração da população na separação do lixo em duas frações: seca e húmida. Existem já projetos de aproveitamento da parte húmida, restos de comida, cascas de feijão, cana-de-açúcar, folhas e ramos, etc., através da compostagem doméstica, transformando lixo em adubo natural. Este projeto, suportado financeiramente pela Cooperação Portuguesa, resultou bem na parte continental do município da llha de Moçambique. Contudo, precisa de um apoio mais continuado. A gestão de resíduos precisa de intervenção do Estado, uma vez que não há capacidade financeira em locais sem dimensão económica.

A visão passa também pelo apoio à machamba (terreno agrícola), a microcultura de bens alimentares capazes de gerar algum rendimento extra para as famílias carenciadas da Ilha. Este esforço passa pela existência de sementes, adubo e capacidade técnica. O adubo poderá ser suprido pela transformação doméstica e comunitária dos resíduos em fertilizante natural. A organização deste tipo de iniciativas inovadoras, criando o slogan "uma família, um compostor e uma machamba", necessita de programas de capacitação e de apoio económico direto para uma fase inicial. O sucesso de um modelo de compostagem 
depende ainda da capacidade do Conselho Municipal da llha de Moçambique [CMIM] em usar o composto (fertilizante natural) nos seus próprios verdes. Segundo o atual presidente do CMIM, a relva dos jardins municipais "está mais verde que a do Estádio do Benfica", vangloriando-se assim, e bem, do seu município ter o que outros não conseguem: espaços verdes de qualidade.

A llha necessita de uma estação de compostagem e processamento de resíduos no próprio território, evitando custos de transporte e o desgaste que é atravessar a ponte. São apenas necessários 1.000 a 2.000 metros quadrados. Sem a necessidade de tecnologias de ponta, mas com conhecimento e reproduzindo experiências bem-sucedidas de outros países nesta matéria. A llha poderia ser um centro de excelência, um modelo de como fazer gestão de resíduos que servisse de inspiração ao resto do país. Existem países disponíveis e capazes de apoiar este tipo de projetos. Há também quadros técnicos, a serem formados no país, capazes de abraçar os desafios emergentes.

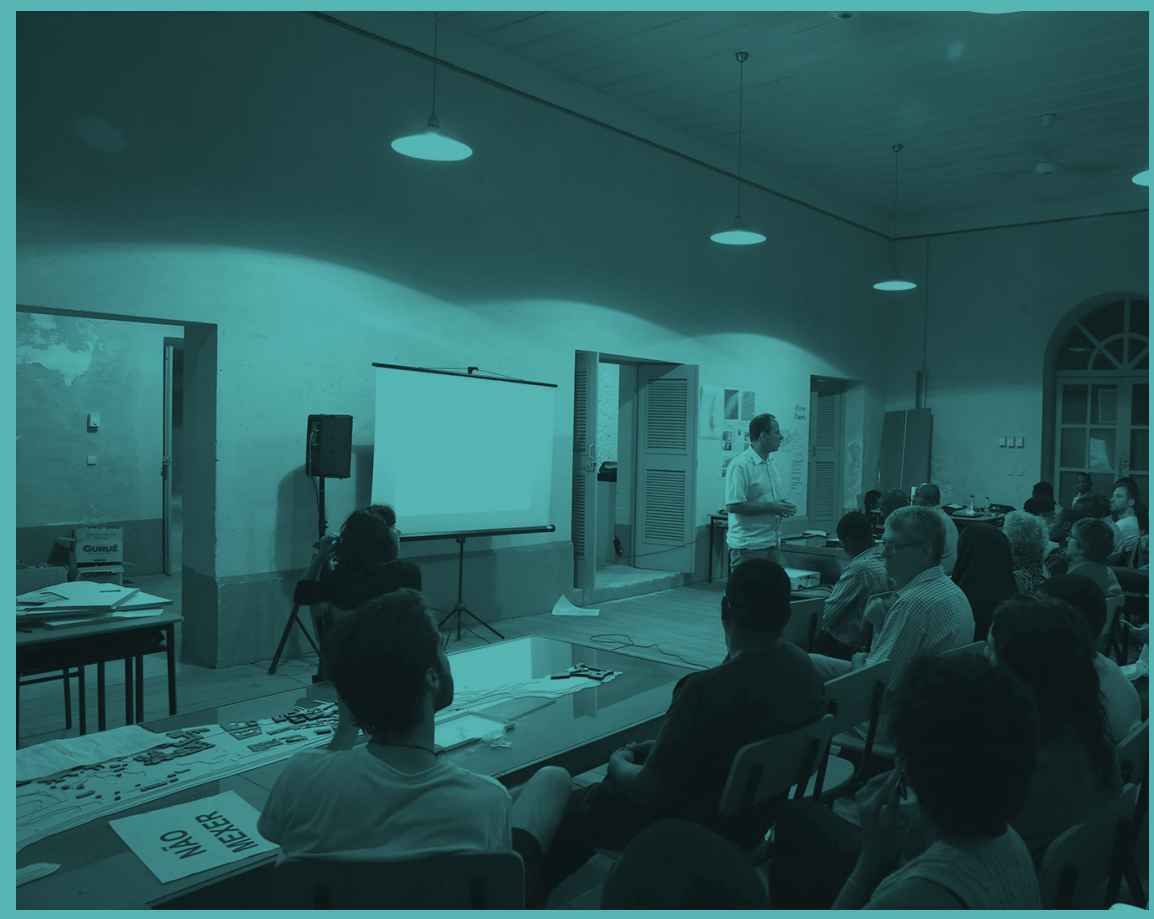




\section{CONCLUSÃO}

A llha de Moçambique é um espaço de uma riqueza única do ponto de vista ambiental, ameaçado pela insensibilidade de uns, desconhecimento de outros, e, ainda, por um novo-riquismo incapaz de perceber a harmonia e as potencialidades deste território. Somos nós (técnicos, investigadores, turistas, visitantes, professores, arquitetos, historiadores, lojistas, artistas, engenheiros, líderes religiosos, empresários, agricultores, jornalistas, cooperantes) que, em conjunto com a população, nos deveremos dedicar à necessária valorização deste Património Mundial, para que seja mais digno da nossa presença, mais sustentável, e um dos melhores locais do mundo para residir, viver e visitar. Sem lixo nas praias, com árvores bem formadas, muita sombra e resiliência às alterações climáticas.

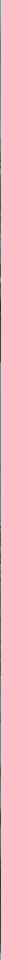




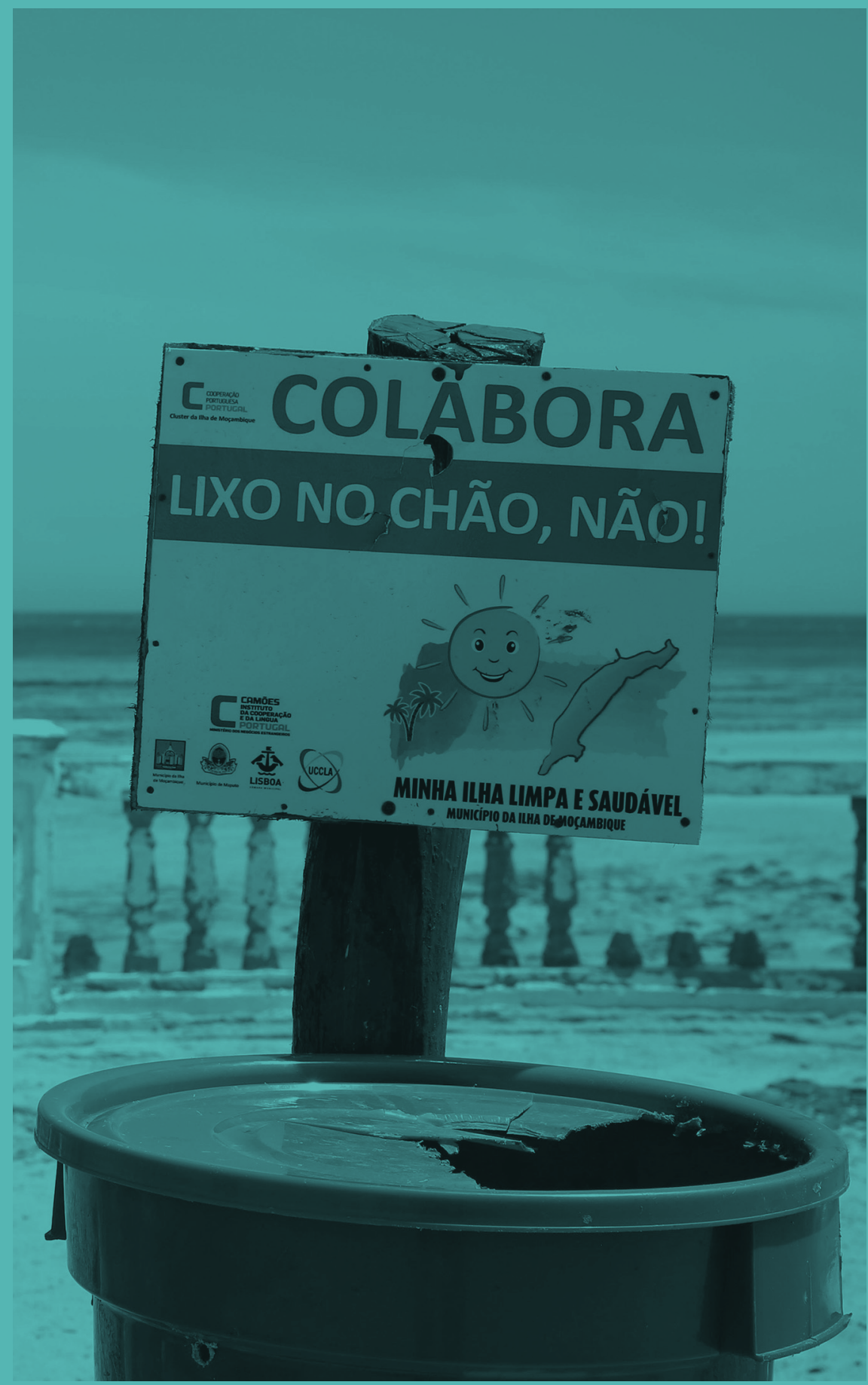




\section{REFERÊNCIAS BIBLIOGRÁFICAS}

LAGE, Jorge (2008), "A biodiversidade é riqueza", TER, revista da Escola Profissional Terra Verde, 2, 42-43.

LAGE, Jorge (2008a), "As Árvores nos Espaços Urbanos", TER, revista da Escola Profissional Terra Verde, 3, 35-36.

PAIVA, Jorge (1999), "Coimbra: as artérias urbanas e as árvores", Cadernos de Geografia - Actas do primeiro colóquio de geografia de Coimbra, 1996, número especial, 49-56. Coimbra: Instituto de Estudos Geográficos, com a colaboração do Centro de Estudos Geográficos, Faculdade de Letras da Universidade de Coimbra.

VAZ, João (2014), "O lixo nos nossos mares". Agência Europeia do Ambiente, consultado a 22.04.2016 em https://www.eea.europa.eu/pt/sinais-daaea/sinais-2014/em-analise/o-lixo-nos-nossos-mares 



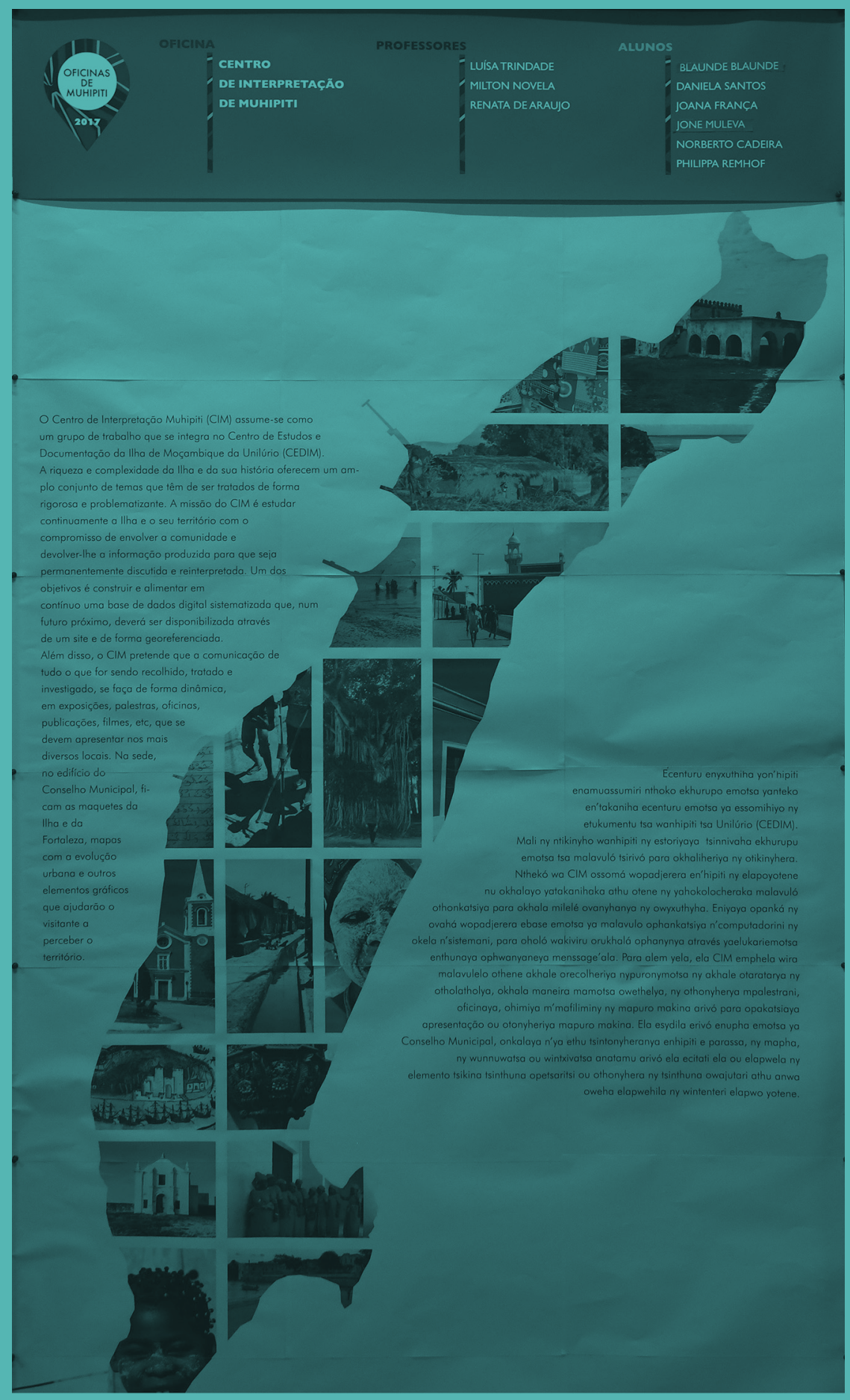




\title{
CENTRO DE INTERPRETAÇÃO DE MUHIPITI
}

\author{
Luísa Trindade \\ Milton Novela \\ Renata de Araujo
}

\section{Missão-encomenda previamente formulada}

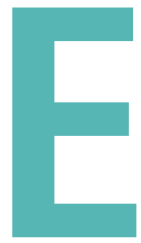

sta oficina tem duas tarefas: a) estruturar e produzir a matriz do que possa vir a ser, no curto e médio prazo os materiais disponibilizados no futuro Centro Interpretativo de Muhipitil Ilha de Moçambique; b) fazer o anteprojeto da respetiva instalação no espaço para tal designado no Conselho Municipal. O objetivo é deixar no local elementos suficientemente detalhados para que a adaptação física do pequeno espaço possa ser iniciada a breve trecho sob orientação da equipa da Universidade Lúrio, e que a equipa da Universidade de Coimbra regresse com dados suficientes para num curto espaço de tempo poder proceder à produção gráfica dos elementos a expor e os envie para montagem. Devem ainda ser produzidas indicações claras para o desenvolvimento deste centro, por exemplo: se não for viável no imediato integrar componentes multimédia, definir o que poderão ser; definir um conjunto prévio de materiais promocionais e de merchandising, bem como a produção ou republicação de álbuns (cartografia, fotografia antiga...), livros (antologias, relatos de viajantes...), etc. Importa registar que as maquetas produzidas para o evento - maqueta da Ilha à escala 1/1000 (1,20m x 3,60m) e maqueta da Fortaleza de São Sebastião à escala 1/200 (1,20m x 1,5m) - deverão ser integradas neste centro. 


\section{En'hipiti nawehaka onira yankani}

En'hipiti nawehaka onira yankani

Nakumbe yulupale

Enukhala mmazini

Wawaka othawene onira mwakó

Enupa zitekié mmalukuni

Molumo khanimaliha ninamuthikilelani

mana ahavotho akina

amiphela wuvanelanani hinhano

watempo ella ninamuvekelani

Mwatthamelale vava zikina

nuthonherani enakalaka mwinizwela

zá n'livuruni massi wohala

orua ti fogo elapo yella nânanupihani 


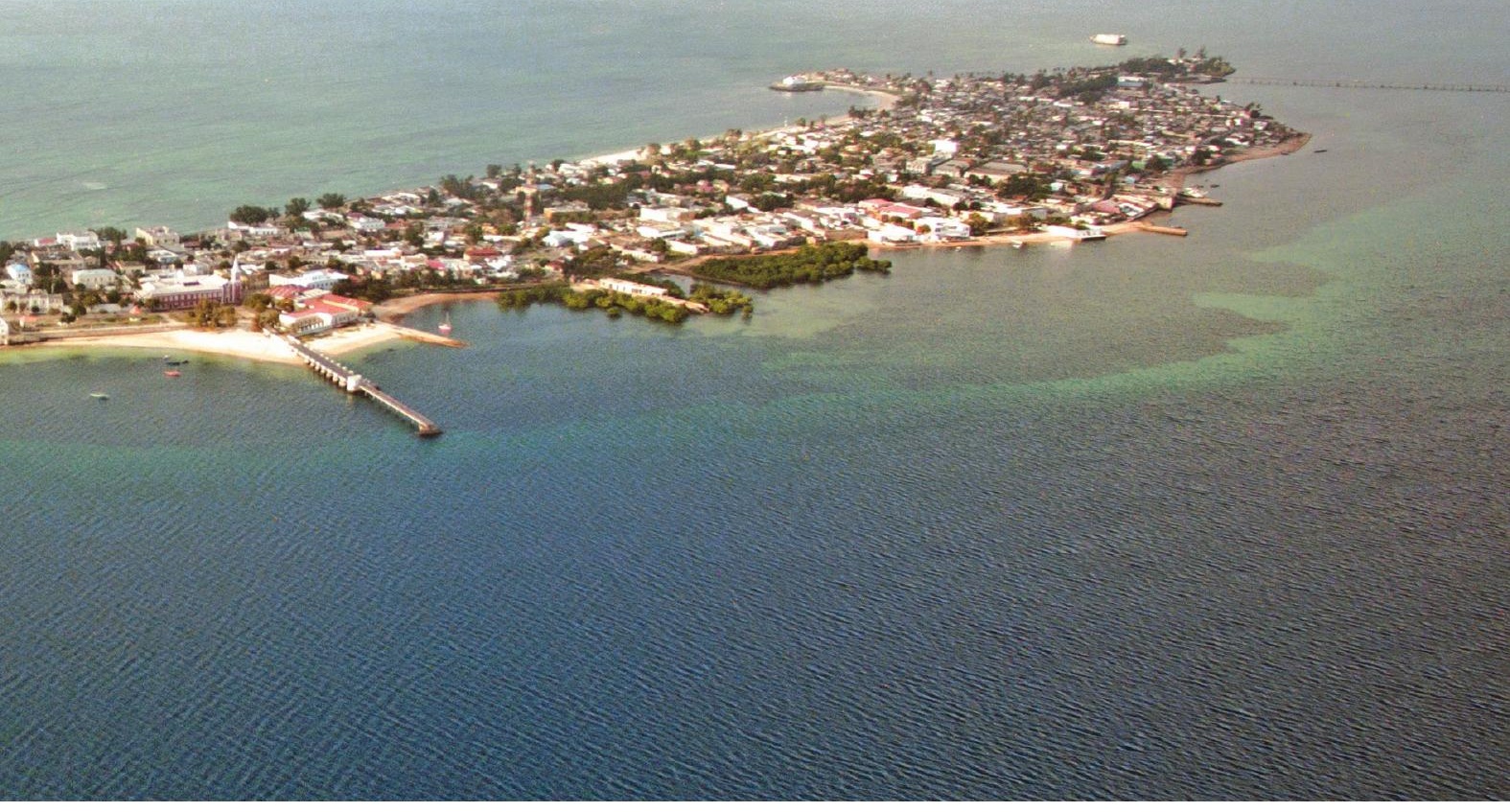

\section{Longe esta ilha parece pequena}

De longe esta ilha parece pequena Esta ilha é grande

Tem longa história desde os habitantes aos seus monumentos Não nos é possível contar-vos tudo quanto temos Pois há outros que querem também falar-vos

Se ainda quereis ouvir algos nossos

Ficais muito tempo nesta llha.

Assim mostrar-vos-iam a rua de fogo Onde vós nunca chegastes

Canção popular macua. Versão livre de Nelson Saúte e António Sopa (1996), publicada na Oceanos, n²5 (p. 127). 
Como bem diz a canção popular, a llha é grande. Não se trata, como é evidente, apenas da distância que se percorre entre a capela do baluarte, numa ponta, e os cemitérios, na outra. Tão pouco é a medida maior do diâmetro que envolve, na terra firme, os territórios adjacentes à baía, que são também partes de um todo, cujo centro é a llha. Os que cantam a canção sabem que, visto de longe, isso tudo pode parecer pequeno. Sabem também que o que é grande é a longa história, que envolve desde os habitantes aos monumentos, e não apenas só estes a falarem sozinhos. Advertem que não é possível contar de uma vez tudo quanto têm para contar, pois há outros que querem também falar. Por isso, perguntam-nos se os queremos ouvir. Esta simples e sábia canção poderia ser o tema musical da nossa experiência no Oficinas. O nosso grupo teve por encomenda a criação de um Centro de Interpretação para a Ilha de Moçambique [CIM]. Cedo percebemos que, antes de fazer qualquer proposta, deveríamos pensar e discutir o próprio conceito.

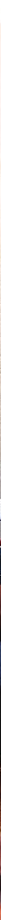


Os Centros de interpretação nasceram na década de 1950, nos Estados Unidos da América, como forma de ajudar a conhecer os grandes parques naturais, cuja escala e diversidade dificultavam a perceção do conjunto. Adaptados a vários fins, os centros de interpretação constituíram-se, no fundo, como a seleção e apresentação de um conjunto de dados que precedia o contacto direto com o objeto, de modo a facilitar a sua leitura.

Formulado pelo norte-americano Freeman Tilden (Tilden:1957; Hicira handbook: 2005), em 1957, na sua obra intitulada Interpreting our heritage, o conceito vem sendo ininterruptamente discutido desde então, existindo um imenso volume de obras produzidas sobre a temática, particularmente no mundo académico anglo-saxónico. O investimento foi definitivamente legitimado quando, em 2008, o ICOMOS ratificou a Carta de Ename, recomendando a interpretação e apresentação como componentes essenciais na conservação e divulgação do património. Profundamente vulgarizado nos últimos anos, o seu número cresce em todo o mundo, sendo usados nas mais diversas situações, de forma tão ampla quanto amplo é hoje o conceito de património. Tudo pode ser e é, de facto, - tratado a partir da figura do centro de interpretação que, assim, se constitui numa parte muito significativa da resposta a esse fenómeno contemporâneo já diagnosticado como doença patrimonial. É, todavia, essa mesma vulgarização que nos obriga a rever criticamente o conceito, aspeto tanto mais importante quanto os seus usos parecem ser genericamente incontestados e a sua filosofia assumida como consolidada.

Não sendo este o local para uma reflexão profunda sobre os problemas que este tipo de dispositivo expositivo encerra (como a tendência para a construção de um discurso unidirecional, tão empobrecido ao nível do conteúdo quanto enriquecido em termos de espetacularidade formal, hoje possibilitada pelos sofisticados meios audiovisuais disponíveis), importa destacar como algumas das suas características podem ser fundamentais na configuração dos mecanismos de descodificação que propomos para a llha.

Desde pelo menos a sua inscrição na Lista do Património Mundial da UNESCO que a llha de passou a ser incluída nos roteiros histórico-culturais do Índico. Como em vários outros casos, o que de certo modo a preservou 

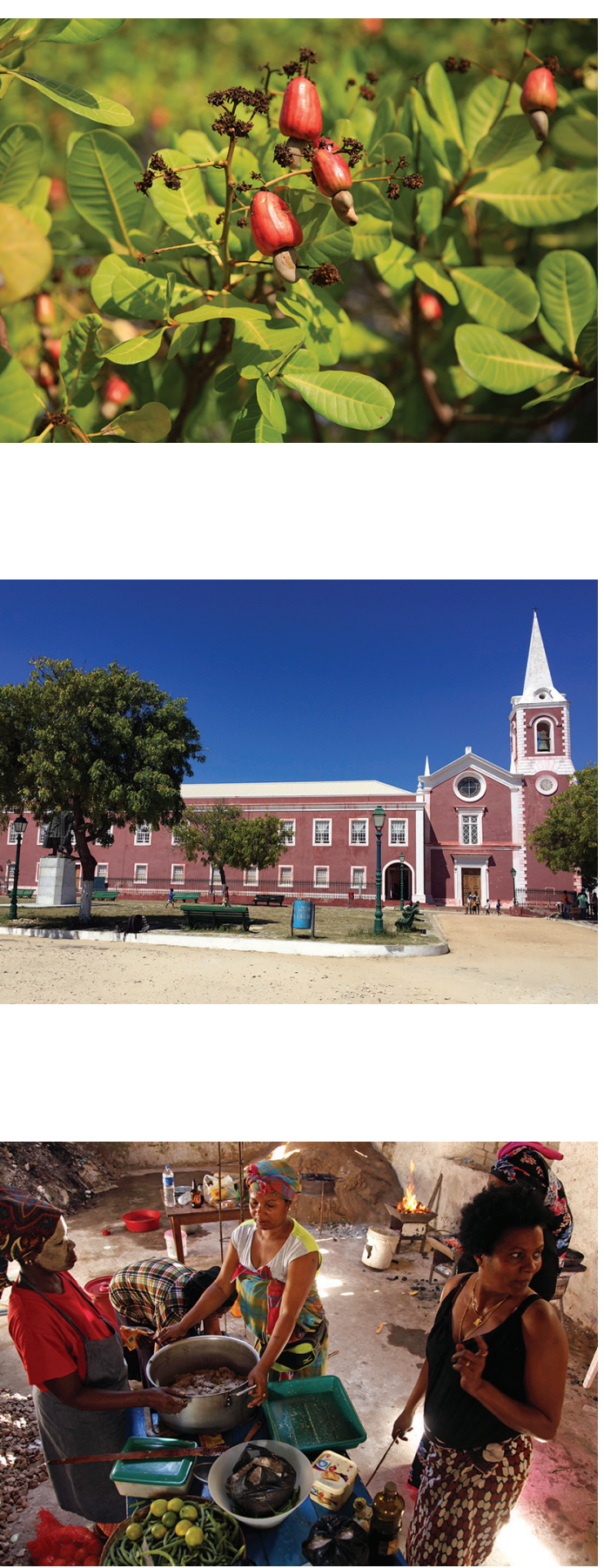

foi o relativo isolamento, vivenciado sobretudo depois da transferência da capital. A llha surge aos olhos dos que a visitam como a imagem de um lugar carregado de memórias que se materializam não apenas nos edifícios, mas também nas comunidades que nela convivem. A perceção e o respeito por todos os aspetos que vinculam a Ilha ao seu passado devem ser tão cruciais quanto os que a mantêm viva, no presente.

Interpretar pressupõe dispor dos dados, no plural e em toda a sua complexidade. Não se trata apenas de adquirir informação, mas de compreender, questionar e, idealmente, reagir. A riqueza e a complexidade da llha e da sua história descortinam um amplo conjunto de temas que vão da arquitetura à botânica, das línguas à gastronomia, das danças aos têxteis. Sem esquecer, evidentemente, as questões mais dolorosas, ligadas ao tráfico de escravos e à escravatura, ao colonialismo e às guerras. Todos os temas exigem ser tratados de forma rigorosa e problematizante. Neste sentido, o que se quer propor não é uma simples montra explicativa para os visitantes, mas um efetivo centro de interpretação da llha e para a llha, que sirva, antes de tudo, aos próprios habitantes.

Mais do que um espaço ou qualquer outro tipo de estrutura 


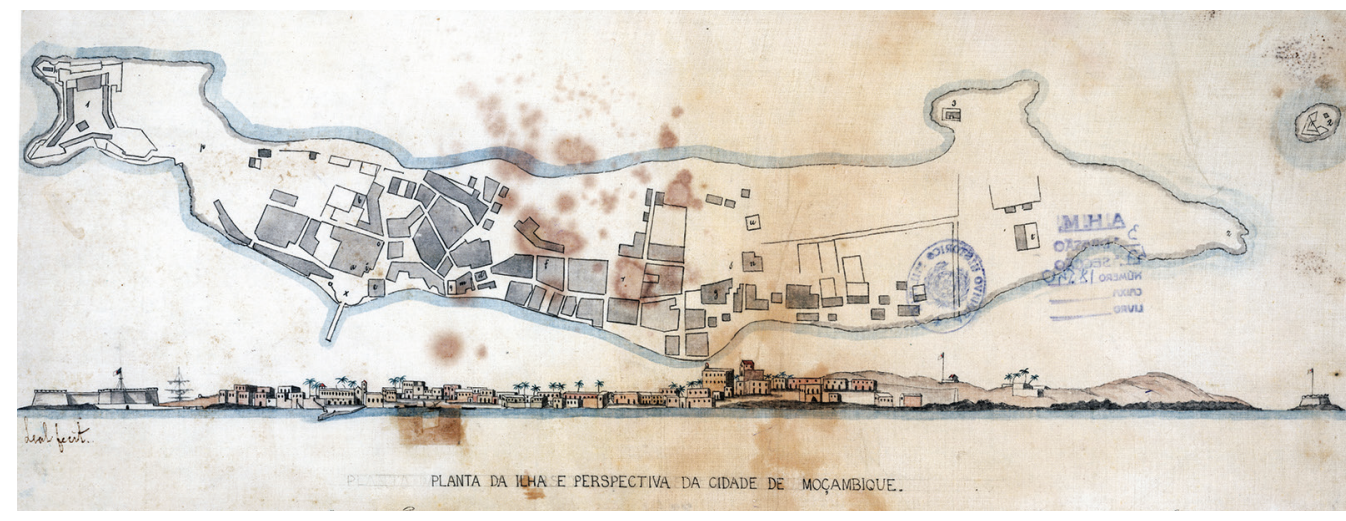

Interpretação deveria ser um grupo de trabalho, plural e dinâmico, cuja base fosse o conhecimento e que imaginamos não só com os estudantes e professores da Universidade Lúrio, mas com a população da própria Ilha e cuja âncora e base propomos que se construa a partir do CEDIM. A missão do CIM é estudar continuamente a llha e o seu território, com o compromisso de envolver a comunidade e devolver-lhe a informação produzida para que ela seja permanentemente discutida e reinterpretada. Um dos objetivos é construir e alimentar em contínuo um conjunto de bases de dados sistematizadas que, num futuro próximo, deverão ser disponibilizadas através de um site e de forma georreferenciada. Numa das bases deverão ser introduzidas informações relativas à bibliografia existente sobre a Ilha, sempre que possível com cópias digitalizadas das publicações cujo acesso seja particularmente difícil. Complementar a esta deverá ser a base de imagens onde se possam recolher cópias digitais, cartografia, iconografia e fotografias relativas à llha. Parte desta recolha de dados já foi iniciada devendo-se dar continuidade ao trabalho de organização e apresentação. Entre outros projetos, prevê-se ainda a criação de um inventário digital, onde se sistematize informações sobre os elementos patrimoniais (materiais e imateriais) da Ilha. Outro dos objetivos do CIM é proporcionar condições para que se possa produzir investigação na própria Ilha, envolvendo não só os alunos e professores da UniLúrio, como também outros investigadores. A partir destas pesquisas, deverá ser organizada uma base de referências e contactos de pessoas fundamentais para o conhecimento dos diversos 
sedimentação de conhecimentos sobre a llha.

Além disso, o CIM pretende que a comunicação de tudo o que for sendo recolhido, tratado e investigado, se faça de forma dinâmica, em exposições, palestras, oficinas, publicações, filmes, etc., que se devem apresentar em diferentes lugares e espaços — desde logo em espaços informais, desde que centrais à própria comunidade — respeitando e integrando os materiais e as possibilidades locais e usando, na sua explicação, as várias línguas que a população fala. Estes são aspetos que consideramos essenciais para que a comunidade se aproprie verdadeiramente do CIM e, assim, se atinja o primeiro dos nossos objetivos.

Na sede, para já no edifício do Conselho Municipal, deverão ficar as maquetes da Ilha e da Fortaleza, assim como mapas com a evolução urbana e outros elementos gráficos e imagens que ajudem a percecionar a materialidade do território e a perceber o papel crucial da Ilha e do contexto mais vasto, como ponto nodal na história das trocas e tensões culturais, comerciais, religiosas e militares do Índico.

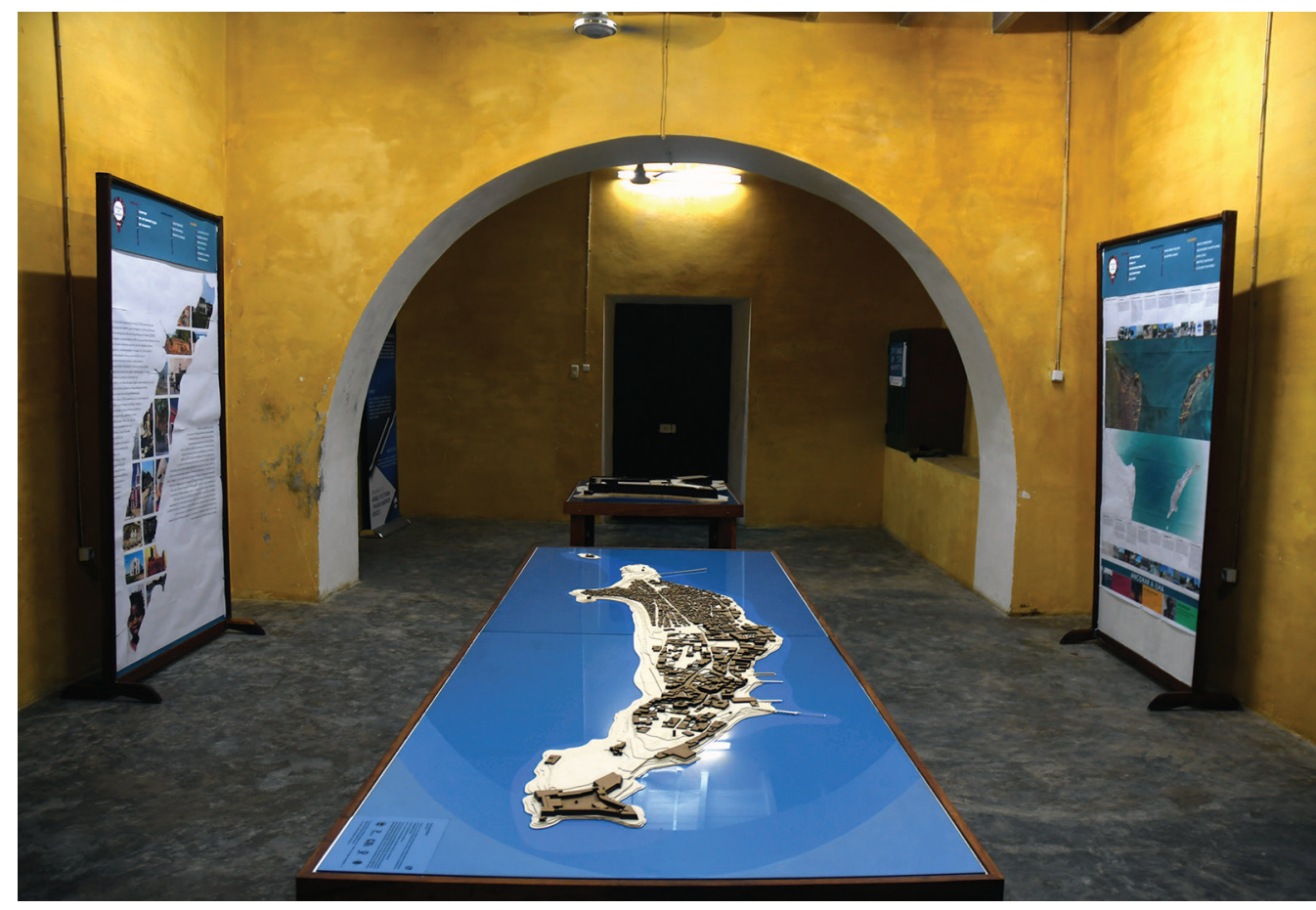


É neste capítulo que o CIM mais se aproxima da configuração tradicional do Centro de Interpretação. Com efeito, o centro interpretativo não tem, por definição, vida própria, apenas se legitimando a partir de uma determinada realidade, seja ela um parque natural, um sítio arqueológico, um centro histórico. Significa isso que se concretiza in situ, atuando em paralelo com o contacto com o(s) espaço(s) cujo conhecimento promove, podendo associar-se igualmente a pequenos troços musealizados, sobretudo nos casos em que a sua preservação é mais urgente. O seu objetivo não é, pois, o de se substituir à realidade, muito pelo contrário: complementa-a, aumentando a qualidade e o potencial da visita. Funciona como elemento polarizador, congregando a informação mais importante para o entendimento do todo, sendo especialmente vocacionado para promover uma leitura global de realidades extensas no espaço e/ou no tempo. É, por isso, especialmente adequado para a descodificação do património urbanístico cuja dimensão, escala e complexidade, tornam a perceção e o entendimento particularmente difíceis.

Ao contrário da experiência que comummente temos quando num museu admiramos um quadro ou uma escultura, a llha e o seu território não se deixam abarcar num único olhar, não permitem que os envolvamos com o nosso próprio movimento, não se deixam ler no seu todo a partir de uma pluralidade de pontos de vista quase simultâneos. Pelo contrário, é a llha e o seu território que nos abarcam. Por isso, as formas de perceção têm que ser necessariamente diferentes. De forma clara, o CIM permite estruturar a informação, recorrendo à exposição cruzada de dispositivos - abstrações, na realidade - que nos auxiliam a ultrapassar as condicionantes próprias deste tipo de património: plantas, maquetas, ortofotomapas, cotejados com outro tipo de materiais como as fotografias antigas e atuais, ou trechos de relatos escritos que permitem perceber a escala, as distâncias e proximidades, a diversidade. São vistas privilegiadas, com efeito, as que este tipo de abstrações proporciona. O seu potencial foi descrito de forma particularmente sugestiva pelos homens dos séculos XV e XVI que, através delas, pensavam ver as cidades e os territórios "como Deus os via" (Ballon e Friedman, 2007: 688). O olhar que, no seu alcance e profundidade, potencia a interpretação, em toda a aceção da palavra. 
Voltando, depois, ao concreto da Ilha, permitem ver as várias cidades nela existentes, a de pedra e cal e a de macuti, desde logo, mas também todas as outras que não têm nome oficial, espaços de transição, por isso especialmente matizados e plurais. Permitem ver o quanto esta llha é grande, como diz a canção que elegemos como tema musical, que também nos convida a ficar muito tempo nesta Ilha. É um convite irrecusável, que o CIM quer continuamente repetir.

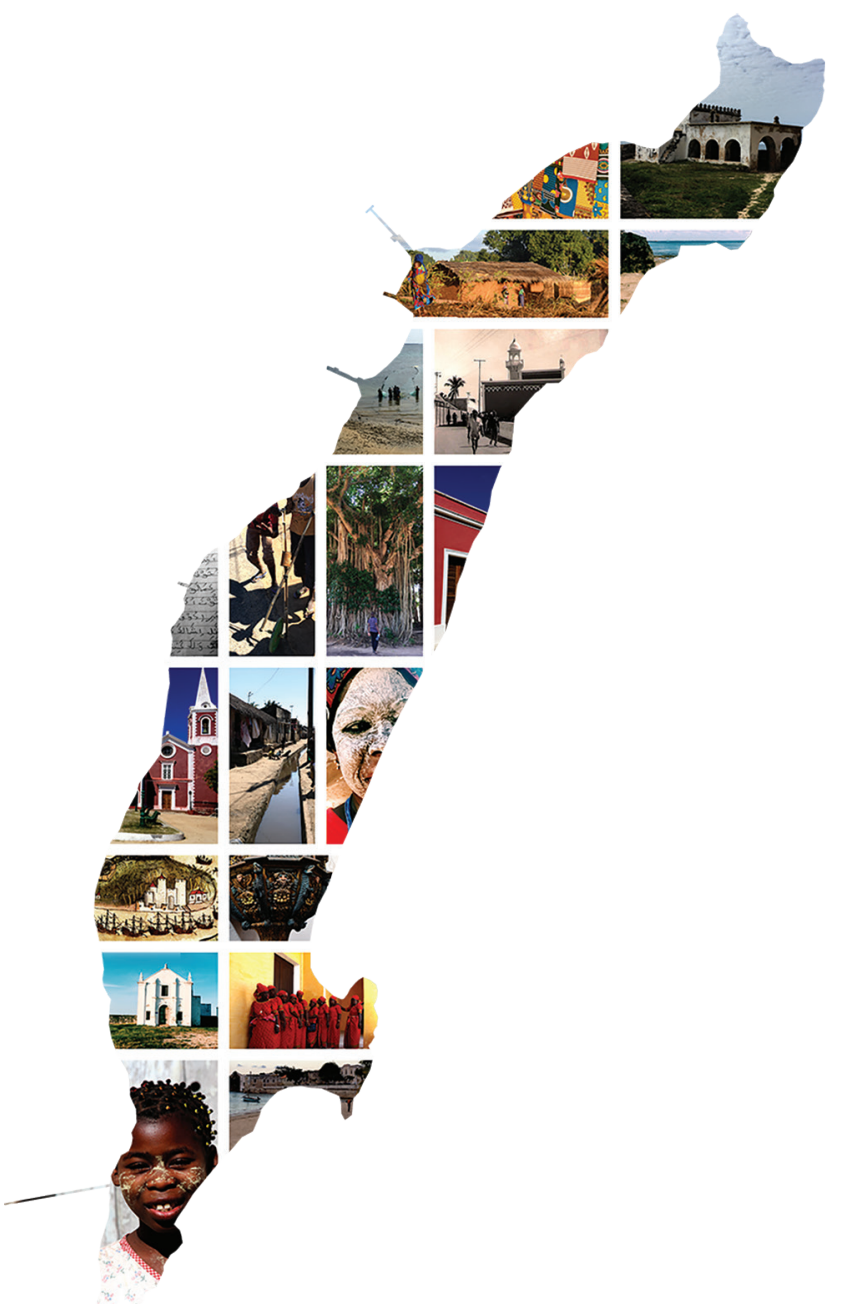




\section{REFERÊNCIAS BIBLIOGRÁFICAS}

BALLON, Hilary; FRIEDMAN, David (2007), "Portraying the City in Early Modern Europe: Measurement, Representation, and Planning", in David Woodward (ed.), Cartography in the European Renaissance. The History of Cartography, 3(1), 688. University of Chicago Press.

HICIRA Project (2005), The Hicira handbook. Heritage Interpretation Centres. Barcelona: Diputació.

ICOMOS (2008), Ename Charter for the interpretation of cultural heritage sites. Paris: ICOMOS.

SAÚTE, Nelson; SOPA, António (1996), "Antologia", Oceanos - Ilha de Moçambique, n 25, Janeiro/Março, 127.

TILDEN, Freeman (1957), Interpreting our heritage: principles and practices for visitor services in parks, museums, and historic places. University of North Carolina Press. 


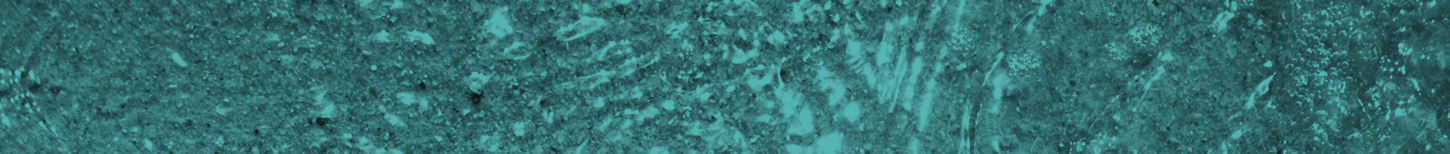

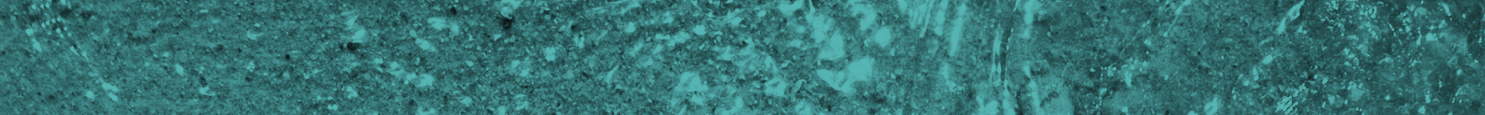

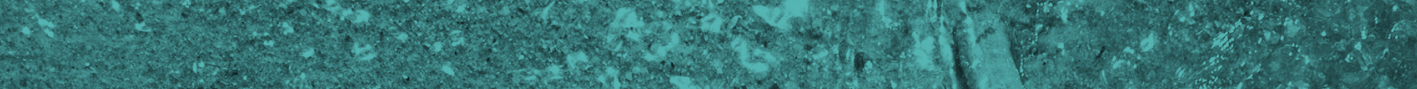

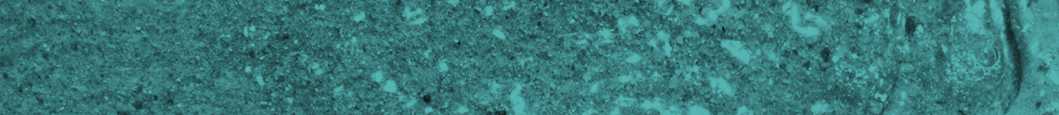

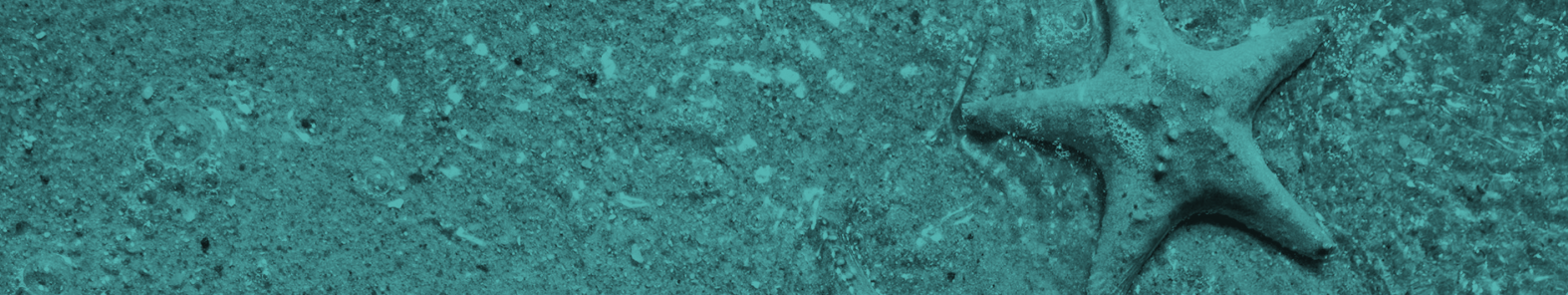

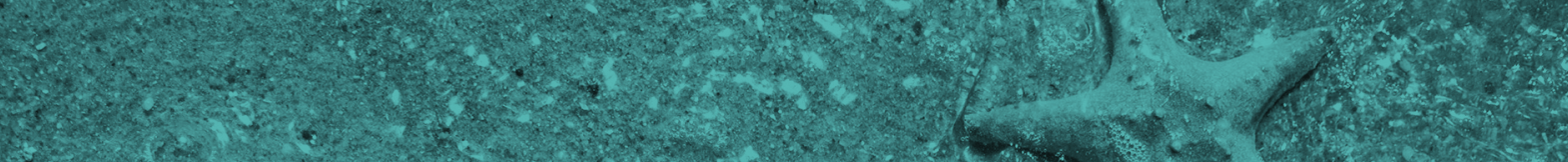

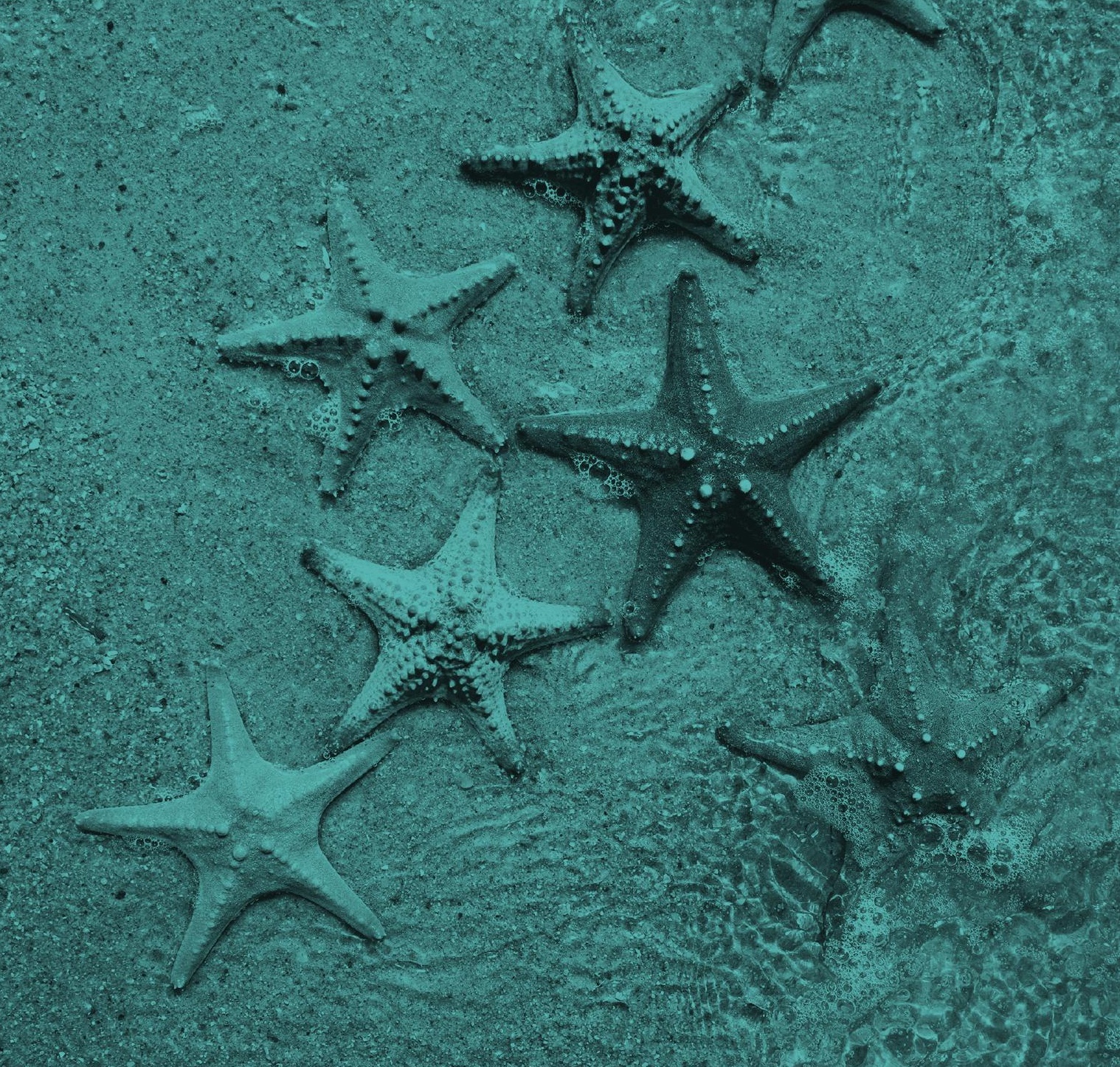

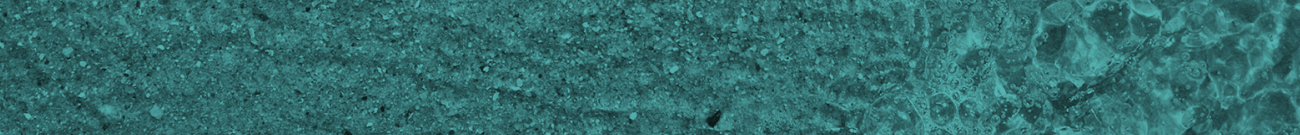

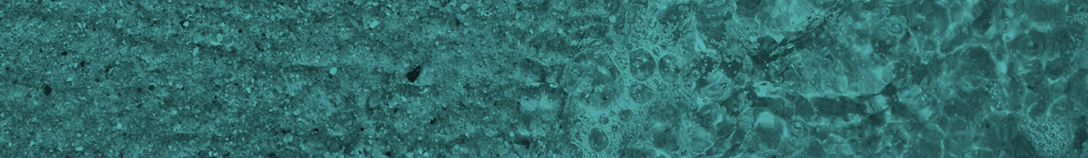

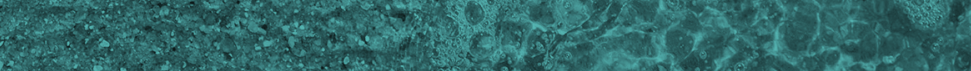

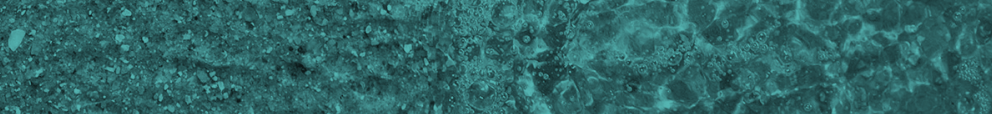

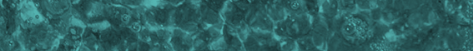




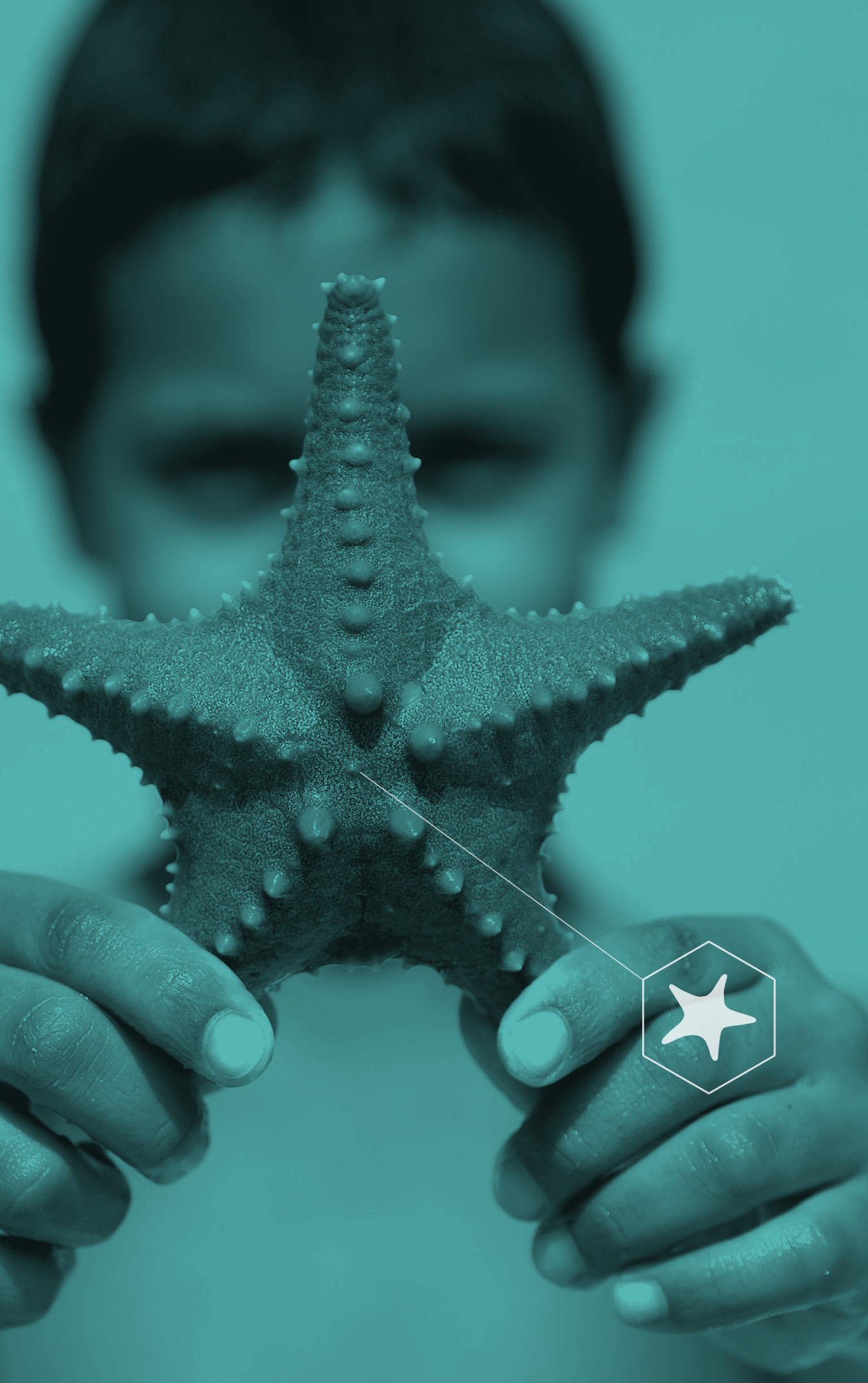




\title{
MARCA-LUGAR MUHIPITI
}

\author{
Helena Soares Rebelo \\ Nuno Simão Gonçalves
}

Oficina pós-evento

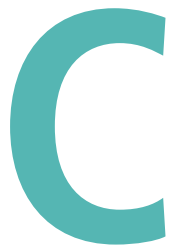

omo ficou dito na Introdução, a elaboração e publicação deste texto corresponde a uma decisão da coordenação do evento e dos organizadores do livro posterior àquele, e resulta da constatação da existência de um trabalho continuado, desde o início do projeto, de construção de uma imagem para o Oficinas, mas também para a llha. Importa esclarecer, desde logo, que a adoção da expressão Muhipiti, usada na língua local para designar a Ilha, resultou essencialmente de três fatores: a sua maior comunicabilidade expressiva, ou seja, a facilidade de uso e de memorização exclusiva (por oposição a Ilha de Moçambique); o estabelecimento de uma diferenciação clara entre uma ação não oficial (como é a nossa e que, pelo menos por enquanto, não é mais do que um exercício), e o que as entidades competentes possam estar a fazer no mesmo sentido; o reconhecimento implícito de expressões locais sob as oficiais, estabelecidas ao longo de um processo histórico que, se contêm a marca do colonialismo, também construíram a identidade e a própria designação do país. Isso não invalida que o caminho aqui proposto não possa ser trilhado com o recurso a outra designação, incluindo a mais comum e, apesar de tudo, equívoca (Ilha) ou a oficial (Ilha de Moçambique). 


\section{CONCEITO DE MARCA-LUGAR}

A ação continuada e consequente de planeamento estratégico necessária ao desenvolvimento sustentável da llha de Moçambique passa, entre muitas outras coisas como as já versadas neste livro, pela criação e promoção de uma marca-lugar (place branding) forte, que concorra para a dinamização e consolidação de uma imagem ambiental, social, económica e cultural positiva a nível global.

Numa definição/tradução de place branding, ainda pouco consolidada em língua portuguesa, o conceito de marca-lugar, como a própria designação indica, consiste num processo de construção de uma marca (branding) aplicada a um lugar (place), seja uma nação, uma cidade ou mesmo uma área urbana. O procedimento inclui o design (identidade visual, logótipo, slogan), o planeamento e a comunicação (marketing) de uma identidade local (Kavaratzis, 2009: 27) — neste caso fomos usando e testando Muhipiti - de forma a construir ou promover uma boa reputação do mesmo, não só para atrair investimento, como também para fortalecer a economia, a cultura e a autoestima das comunidades locais (Kavaratzis, 2004: 58; Anholt, 2006: 5).

Anholt (2006: 25-26) defende que uma identidade competitiva assenta em seis vértices de um hexágono que interagem entre si:

- Turismo: a forma como é promovido e qual a primeira impressão que os turistas formam do lugar;

- Políticas que apoiam e sustentam o investimento local;

- Marca: potencialidades ou vocações que distinguem e caracterizam o local;

- Investimento nacional e internacional no local;

- Trocas e atividades culturais que promovam e dinamizam a cultura endógena, não só in-loco, como aos níveis regional, nacional ou global;

- Habitantes e o seu engajamento no processo de promoção do lugar, na forma como recebem os visitantes e como incorporam a sua marca.

Este esquema hexagonal pode ser adaptado conforme as especificidades locais. No caso das cidades, as variantes dos vértices devem ajustar-se aos fatores que se pretende avaliar, realçar ou comparar. 


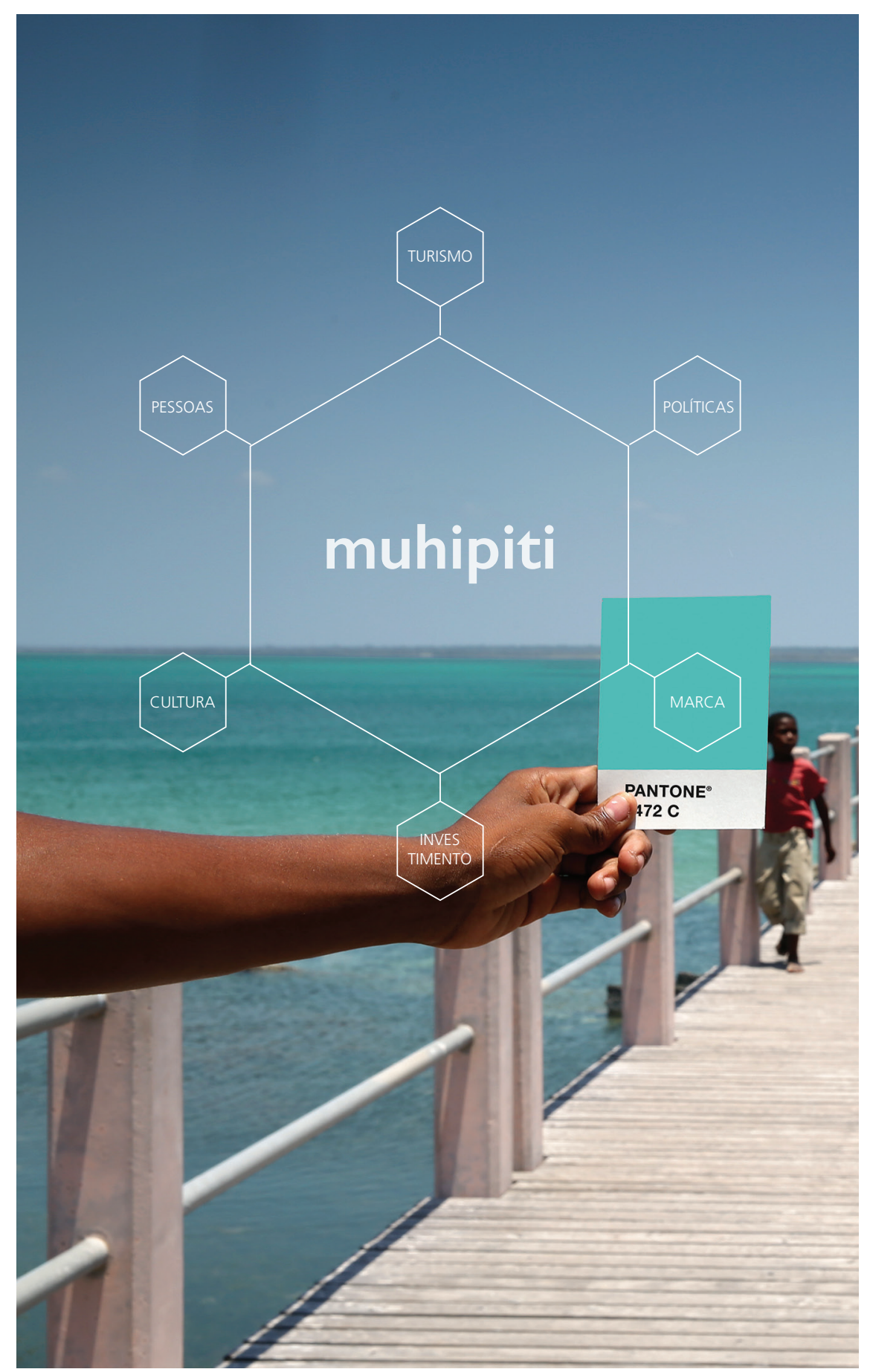




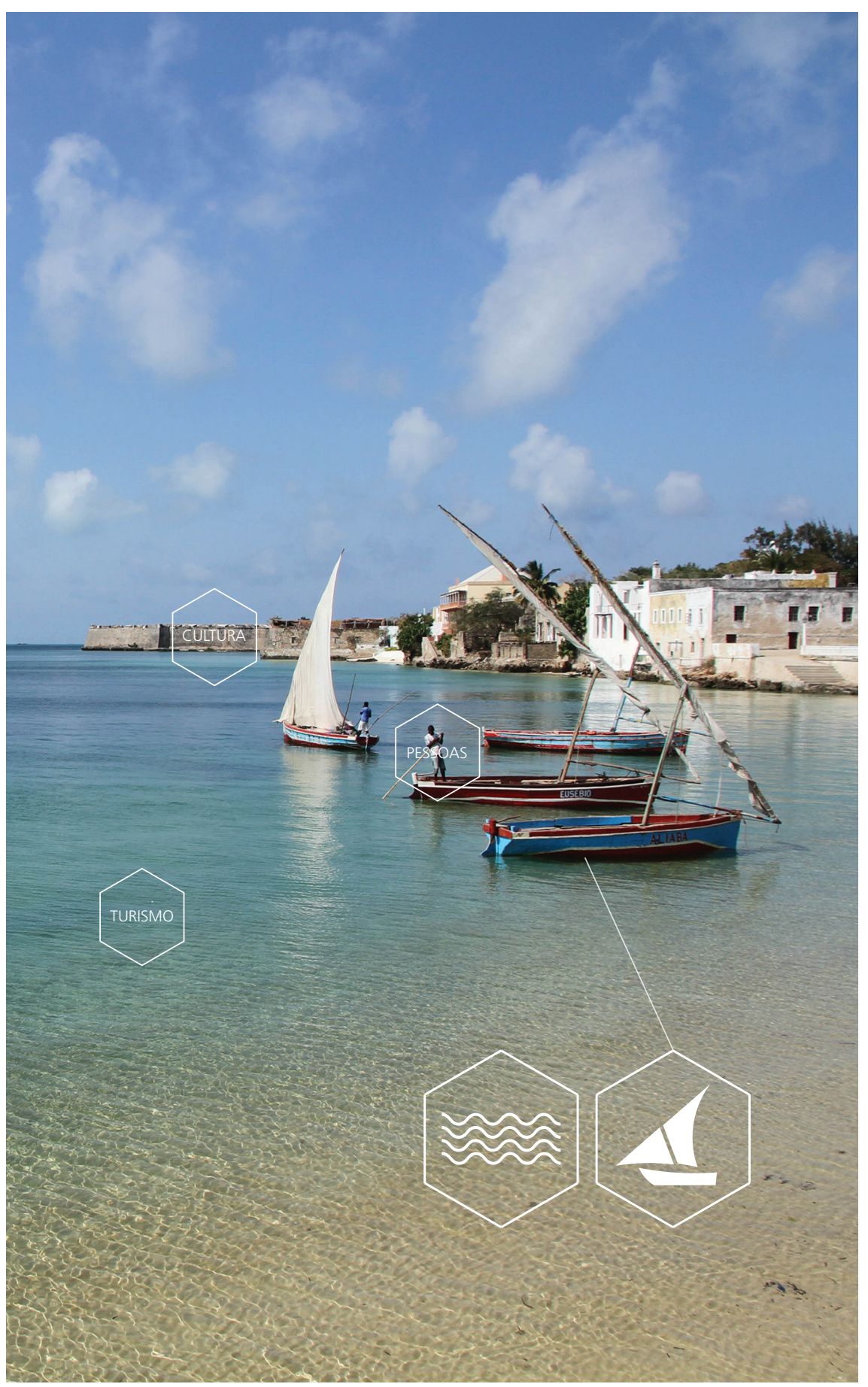




\section{BRANDING EM ÁFRICA}

No continente africano, os desafios para promoção e valorização dos lugares são prementes. A maioria dos países enfrenta problemas socioeconómicos e urbanos profundos que mobilizam e priorizam as políticas governamentais e dos financiadores externos. Muitos ainda se debatem com guerra, altos níveis de pobreza, iliteracia, corrupção, criminalidade, instabilidade económica e social, problemas que têm sido difundidos, enfatizados e gravados na opinião pública internacional desde meados do século passado (Youde, 2009: 127). Para inverter estes cenários é necessário que os países invistam na (re) construção de imagens otimistas dos seus territórios, conquistando a confiança dos investidores e visitantes internacionais e renovando a autoconfiança dos seus cidadãos (Wanjiru, 2006: 86-87).

A proximidade geográfica e cultural com a llha de Moçambique possibilita usar Zanzibar como exemplo comparativo para este estudo. Desde 2010 que a Comissão de Turismo de Zanzibar, em conjunto com os principais atores locais (designadamente agentes turísticos, tem vindo a criar uma marca única para a ilha ancorada em dois segmentos turísticos: cultura e história; sol e praia. O primeiro enfatiza não só a cidade de pedra (arquitetura e espaço urbano), inscrita desde 2000 na Lista do Património Mundial da UNESCO segundo os critérios ii, iii e vi (UNESCO, 2000), como também a rota das especiarias, a gastronomia, os festivais, as ruínas fora da cidade, as aldeias e mercados, o artesanato, a música, a população e a cultura swahili. Já a vertente sol e praia destaca as praias de areia branca, as águas transparentes e mornas de cor azul turquesa, o clima tropical, os bancos de coral ou de areia, as ilhas desertas e os barcos tradicionais, os dhows (Serengeti Advisers and Acorn Tourism Consulting, 2010: 29-32). É importante salientar que, apesar de Zanzibar ter duas universidades (uma privada e uma pública), que datam do final do século passado, não estão integradas nessa estratégia de promoção da cidade. 


\section{MARCA-LUGAR MUHIPITI PARA A ILHA DE MOÇAMBIQUE}

Para materializar uma marca-lugar para a Ilha de Moçambique é importante ter em conta os princípios defendidos por Anholt (2006: 25-26), dos quais aqui se destacam a necessidade de enaltecer as potencialidades e vocações que a distinguem e caracterizam, direcionando e/ou captando as políticas e os financiamentos para apoiar e sustentar o investimento local, nacional e internacional. É necessário fomentar atividades culturais (festivais, workshops, participação em redes) que promovam e dinamizem a marca, dando a conhecer características intangíveis que permanecem por explorar como, por exemplo, a dança de Tufo e a gastronomia da Ilha de Moçambique. Conforme já referido, será imprescindível o engajamento dos ilhéus de Moçambique, em particular representantes comunitários, comerciantes e agentes turísticos em todo o processo de promoção do seu território, de forma a, numa abordagem bottom-up, não só melhorarem a sua recetibilidade aos visitantes ou novos habitantes (Ministério da Cultura e Turismo, 2017: 54), como também assumirem o compromisso de incorporar e promover a marca-lugar. Além disto, este contributo comunitário poderá reforçar o seu sentimento de pertença e autoestima fortalecendo o caráter desta marca-lugar.

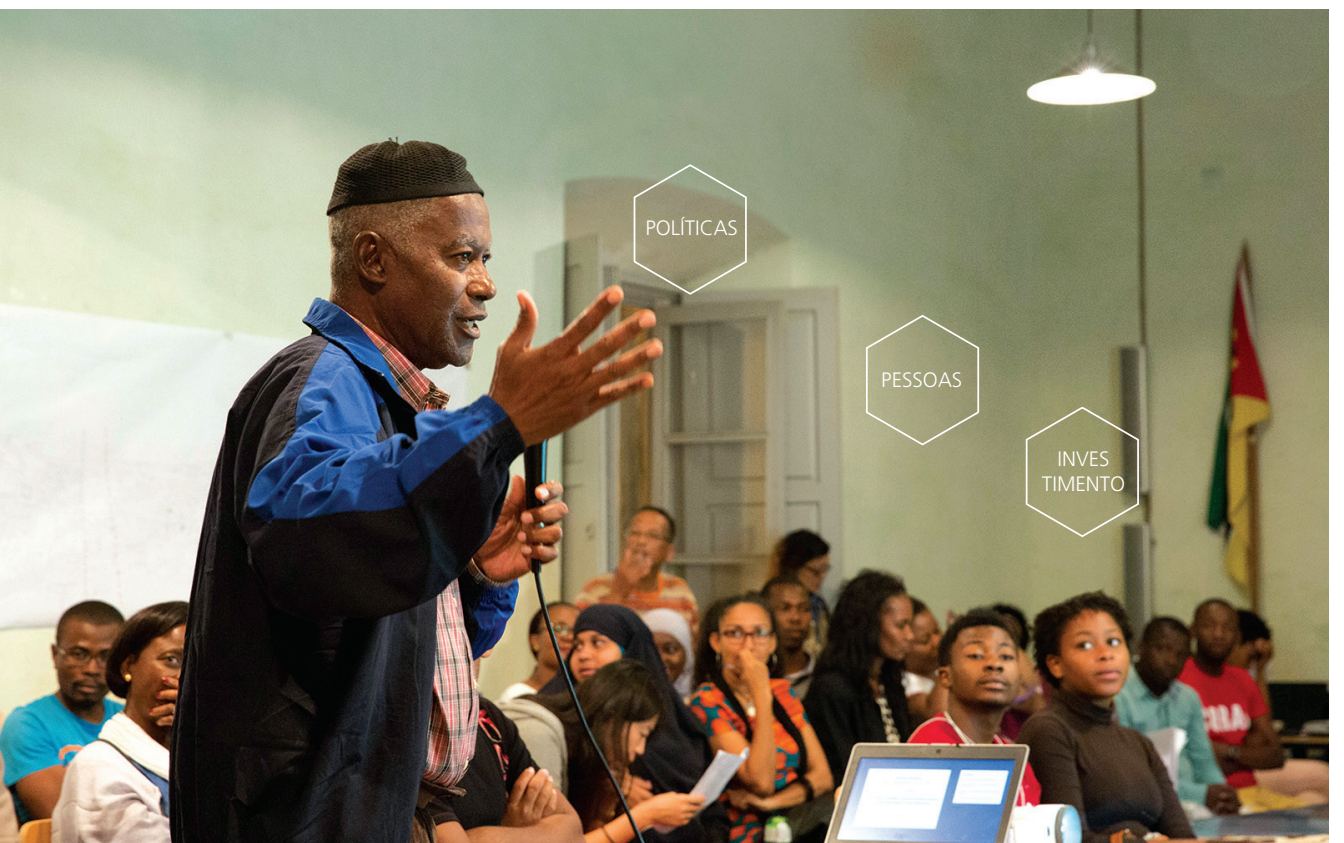




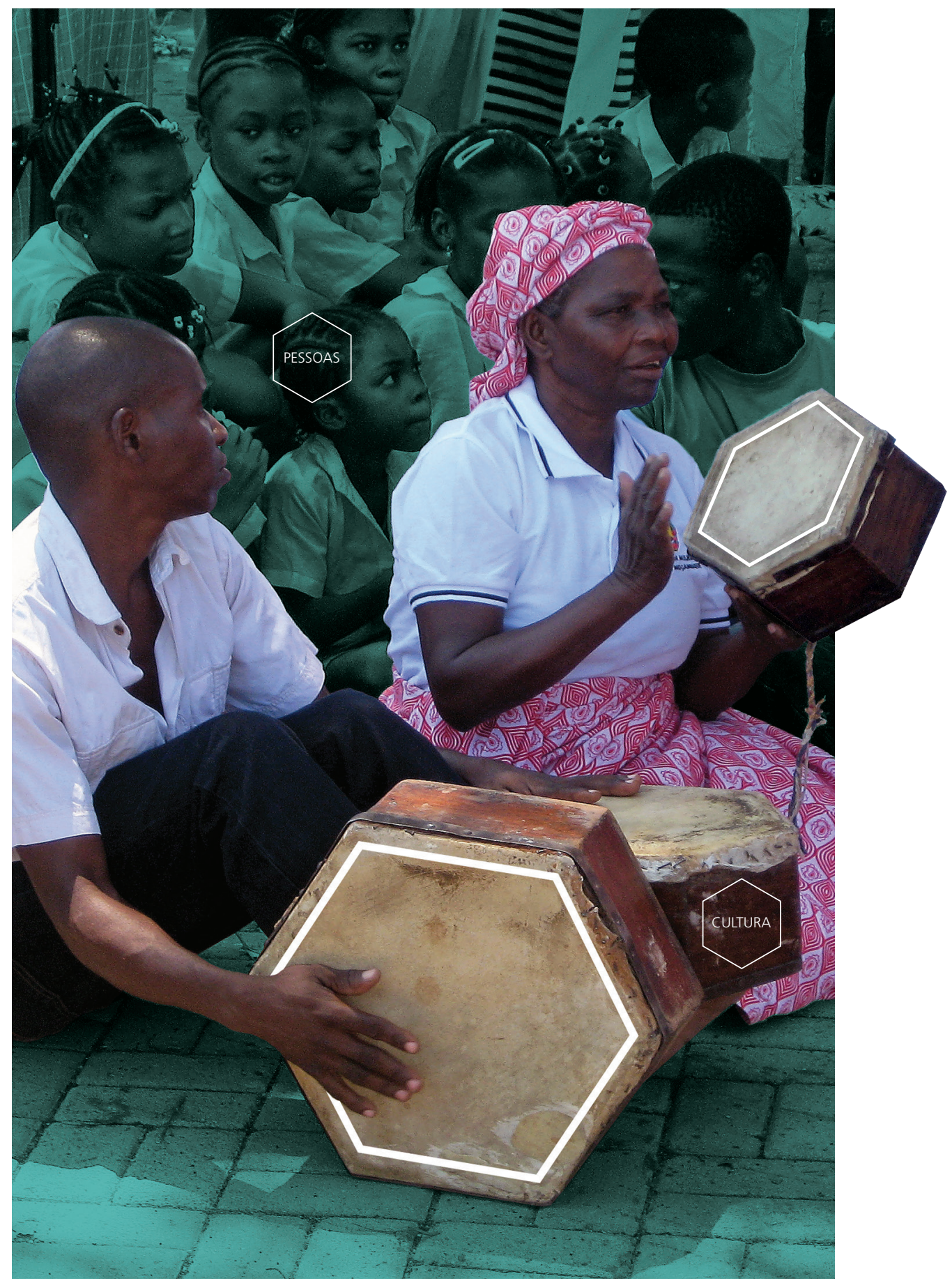




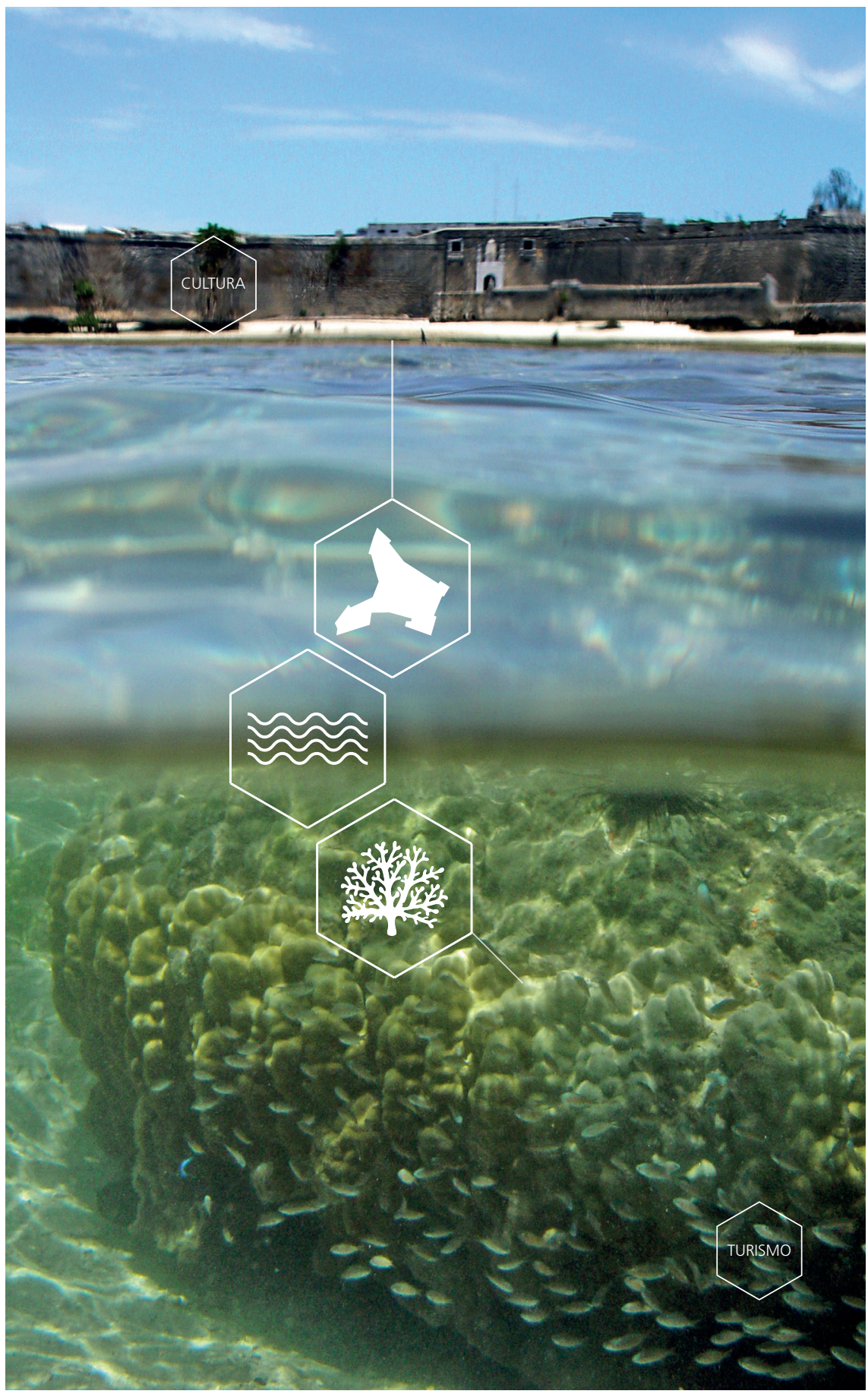




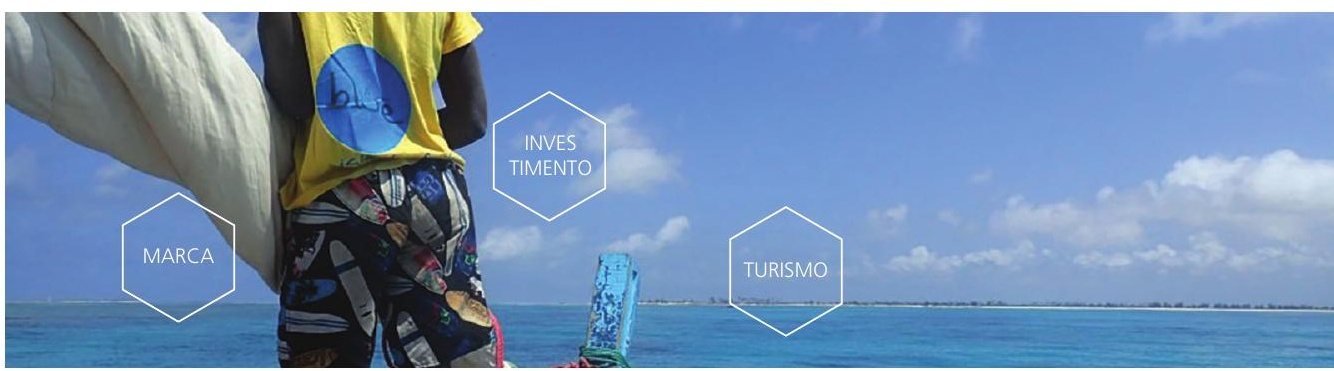

\section{POTENCIALIDADES E VOCAÇÕES DE MUHIPITI}

As potencialidades das zonas insular e continental abrangidas pela jurisdição da llha de Moçambique são várias e, conforme referido, deverão ser elencadas com a contribuição dos stakeholders, incorporando as suas sugestões e algumas ideias já em prática. Existem bons exemplos de trabalho de promoção turística já desenvolvidos, como a llha Blue, Genito Magic Tour (Genito Molava), Gito (António Giquira), entre outros.
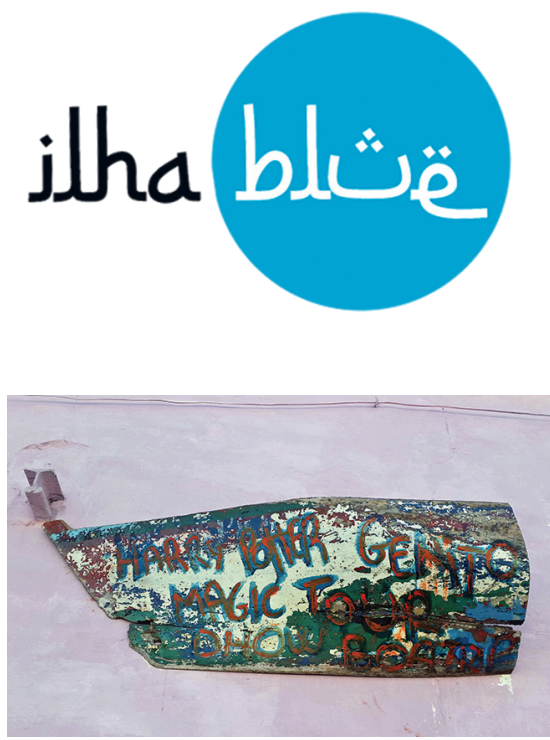

Nessa linha, dividimos algumas das potencialidades/vocações em três eixos, sabendo que num trabalho mais exaustivo outros deverão surgir:

- Eixo 1: formação avançada;

- Eixo 2: turismo e suas ramificações;

- Eixo 3: principais atividades económicas de captura e transformação de produtos endógenos (como a pesca, o sal, ou a castanha de caju).

A intenção é que estes eixos não se desenvolvam paralelamente, mas partilhem pontos sinergéticos, ajudando a atribuir consistência e coerência à marca. 


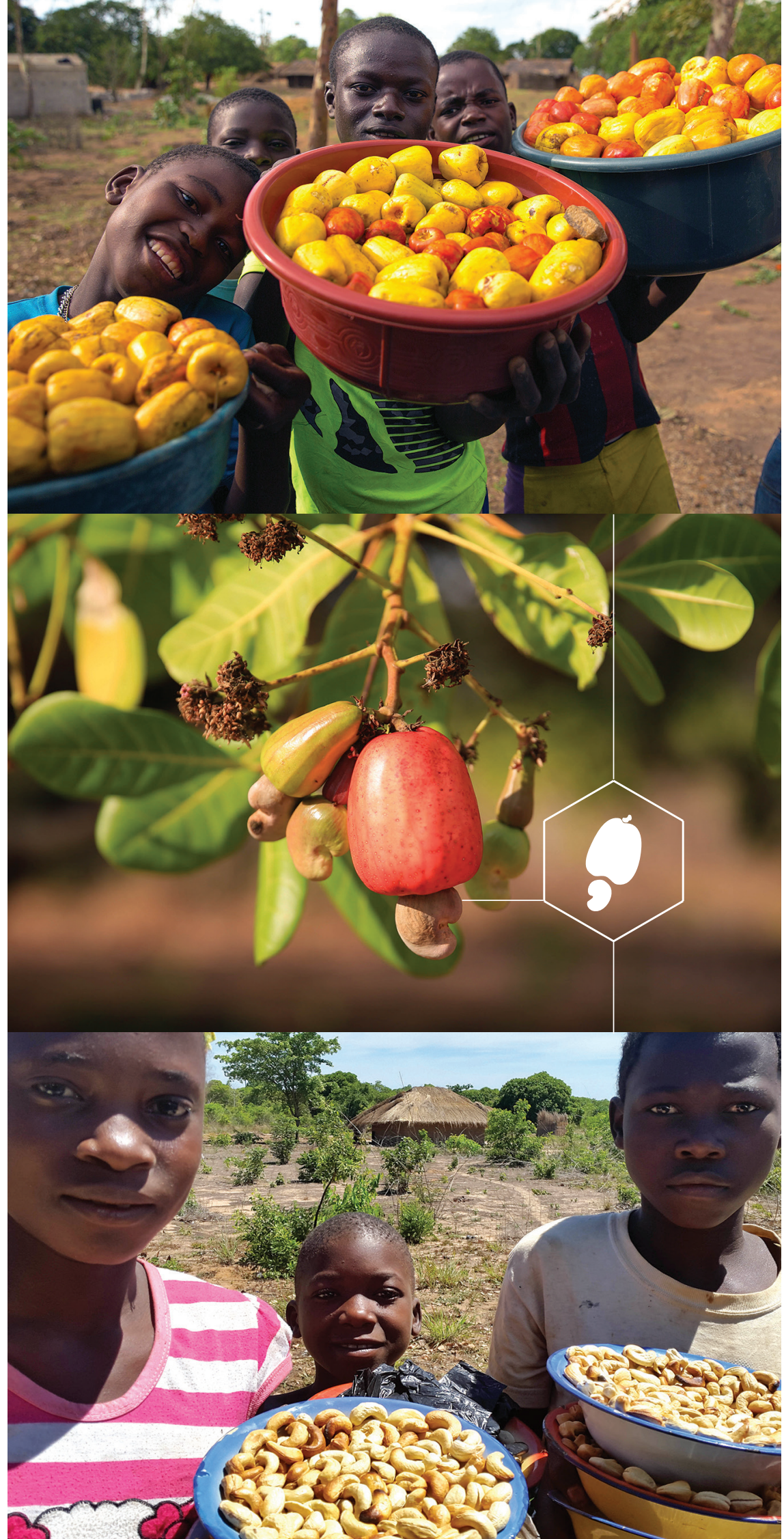




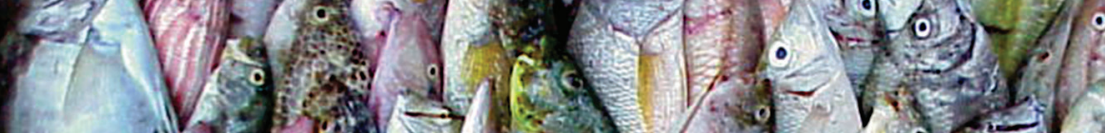

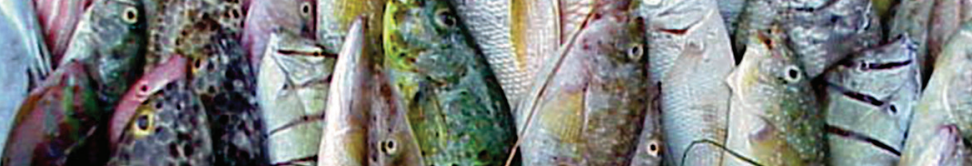

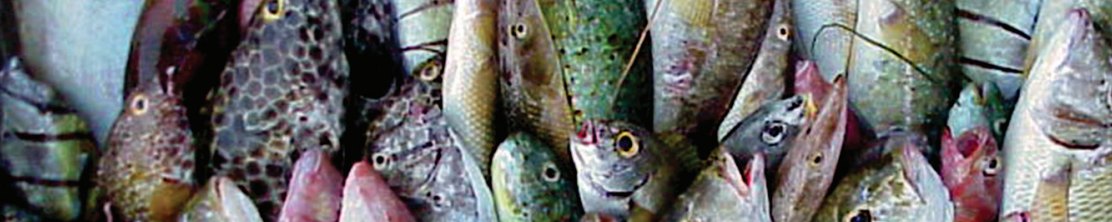

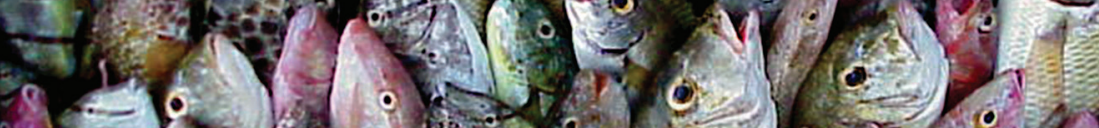

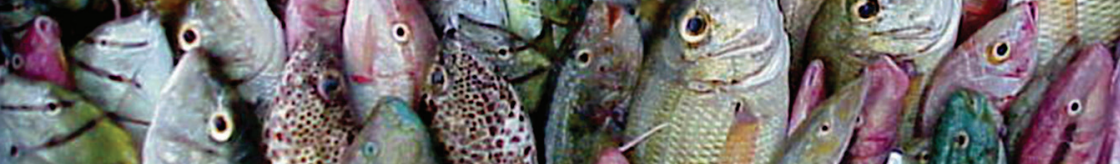

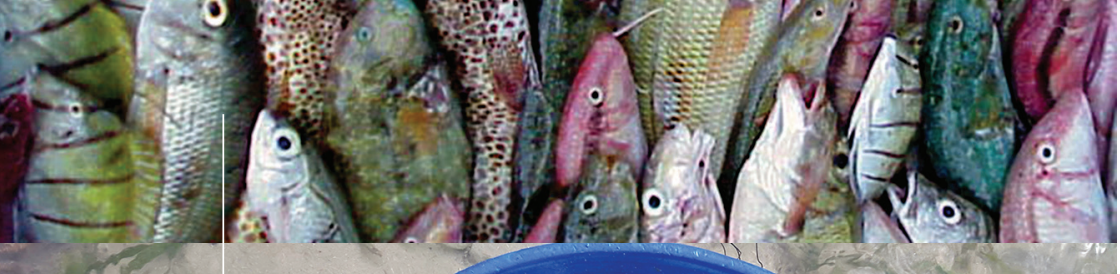
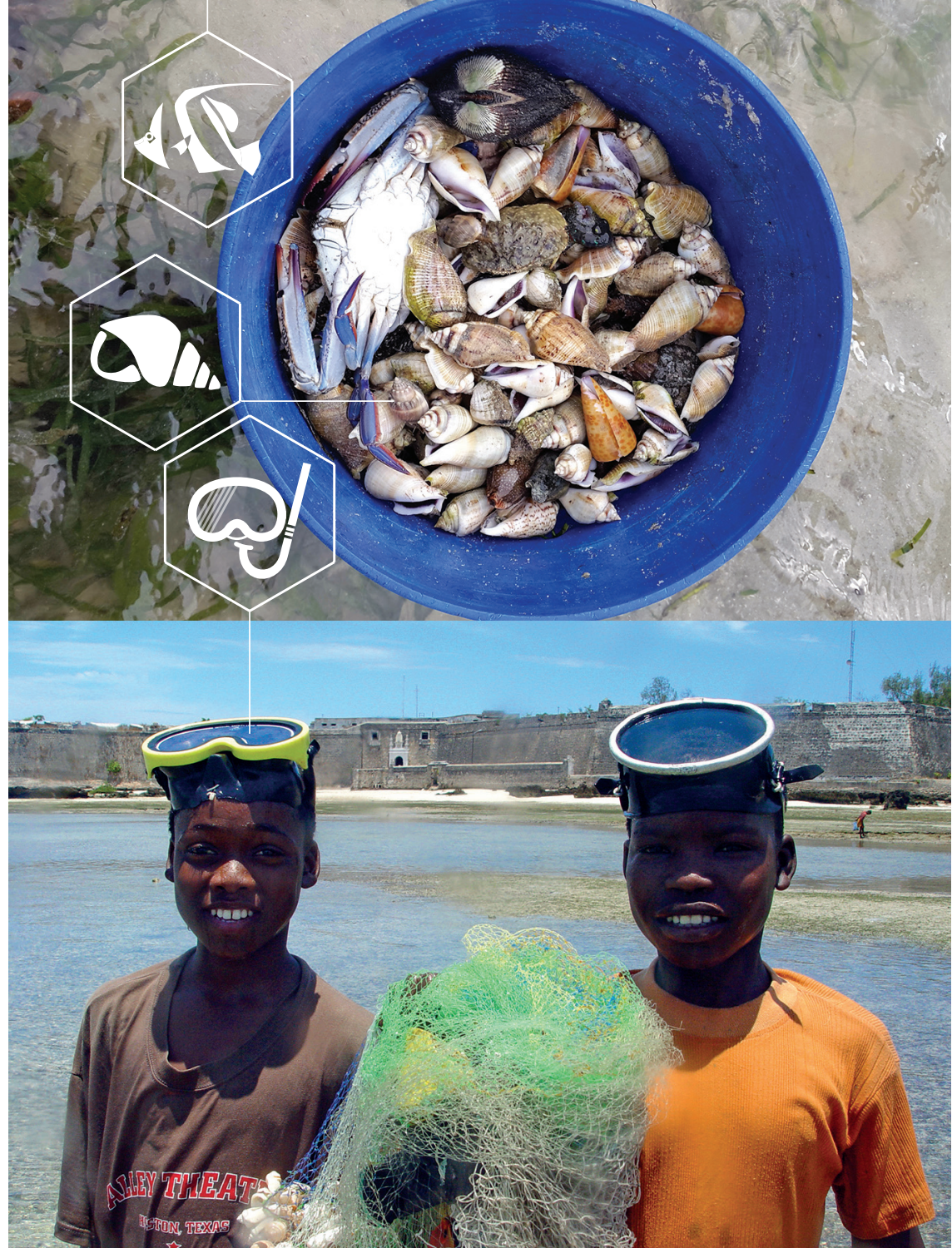
Ao analisar-se o Eixo 2, importa referir o documento Estratégia de Marketing do Turismo para Moçambique (Ministério da Cultura e Turismo, 2017: 44), no qual se estabelecem metas para o quinquénio 2017-2021. Neste, a importância estratégica da Ilha de Moçambique ficou diluída no meio das demais regiões, tendo, inclusivamente, sido relevada como parcela integrante de um dos cinco destinos estratégicos nacionais, no das Quirimbas. Apesar disso, na secção "Acções Específicas a Desenvolver", só se faz referência à Ilha de Moçambique (ibidem, 2017: 35-36). Para contrariar esta diluição nacional, é crucial a criação de uma marca local forte, diferenciadora e autónoma. Entre outras, há uma enorme vantagem que poderá ser muito útil à Ilha: nos últimos anos o país tem sofrido perturbações sociopolíticas de diversas ordens, em particular nos conflitos armados no centro e, mais recentemente, no extremo norte do país, projetando uma imagem de insegurança para o exterior, generalizada a todo o território, retraindo o investimento e o fluxo turístico, mesmo em locais onde essa insegurança é inexistente, como é o caso da llha. Assim, distanciá-la da conjuntura negativa do país através de uma imagem própria, coerente e positiva, poderá devolver-lhe os créditos de local idílico e seguro para visitar, fator essencial na escolha de turistas e investidores (Wade, Mwasaga e Eagles, 2001: 99-100). A promoção dos ativos turísticos da Ilha, tal como em Zanzibar, poderá ser subdividida em dois segmentos: um ligado à cultura e história, outro ao sol e praia. O primeiro focado na promoção das heranças culturais e na grande variedade de património material e imaterial implícito com ênfase na interação e fusão de culturas, manifestado não apenas na arquitetura e no urbanismo (cidades de pedra e cal e de macuti), como, por exemplo, na gastronomia (ciriciri), na música e na dança (tufo e maulide), no artesanato (missangas centenárias garimpadas pelas crianças nas praias) e na literatura (Luís de Camões, Rui Knopfli, entre outros poetas que cantaram a llha). A inscrição na Lista do Património Mundial da UNESCO promove-a como produto turístico de cultura e história de excelência. Será fundamental realçar este estatuto na marcalugar, dignificando-o e conferindo-lhe visibilidade. Ainda neste segmento, haverá que salientar bens fora da llha (a Igreja de Nossa Senhora dos Remédios, o Palácio do Governador e o cemitério árabe na Cabaceira), as aldeias (Jambese, Sancul, Lumbo, Cabaceiras Grande e Pequena) e um traço de singularidade, a integração na grande cultura swahili. 
Poderão integrar-se rotas swahili mais abrangentes, ligando congéneres costeiras e insulares até Zanzibar. Há ainda a possibilidade de integrar outro tipo de rotas, como o das pinturas rupestres da Província de Nampula, das quais são exemplo as diversas inscrições de figuras milenares existentes num afloramento rochoso em Nacavala.

O segundo segmento, sol e praia, englobará o clima tropical, as praias de areia branca com águas transparentes e mornas de cor azul turquesa, os bancos de coral e a biodiversidade, especialmente marinha (ecossistemas coralíferos, cetáceos, entre outros). Poderão promover-se não só locais relativos à Ilha (praias da Alfândega, do Ancoradouro, do Carramo, da Fortaleza), como também das ilhas desertas circundantes (Goa, Sena, Cobras e Sete Paus) e do continente (Lumbo, Sancul e Cabaceira Pequena). A interligação com estes locais insulares e continentais fomentará necessariamente percursos nos dhows. O potencial costeiro poderá ainda proporcionar atividades ligadas ao mergulho de superfície e de profundidade. Este último, tem no mergulho arqueológico um ativo diferenciador, jazendo ao largo da llha diversas embarcações naufragadas, interagindo com o eixo cultural.

As principais atividades económicas (Eixo 3), também podem ser incorporadas de forma a beneficiarem da chancela Muhipiti. Uma vantagem imediata será a utilização de uma imagem de marca graficamente coerente e apelativa, que promova e acredite os produtos endógenos, criando sinergias com os outros eixos. A formação avançada contribuirá, decerto, com investigação sobre estas atividades e respetivos produtos, de forma a otimizar a sua rentabilidade. Já o turismo, poderá ajudar a divulgar e valorizar os produtos através de visitas guiadas aos respetivos processos de recolha e transformação, postos de venda e criação de centros interpretativos. 


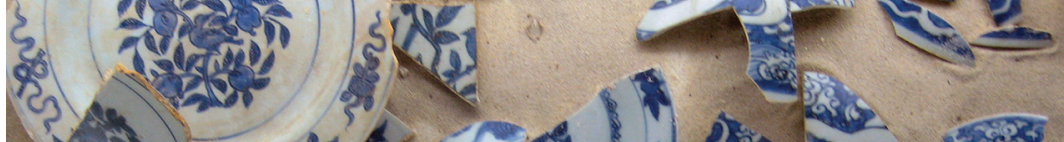
(a) (1)
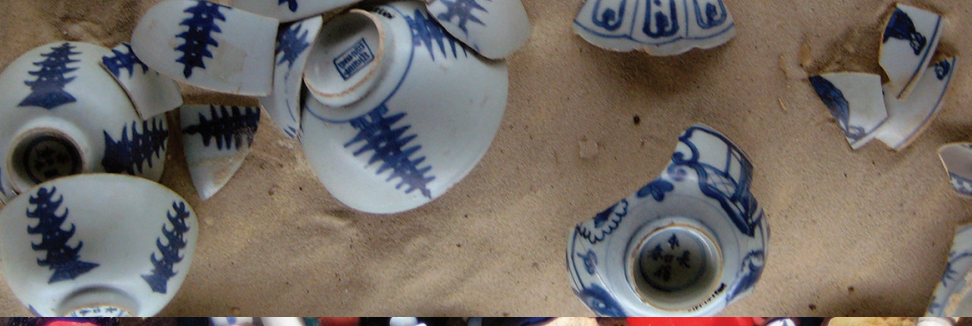

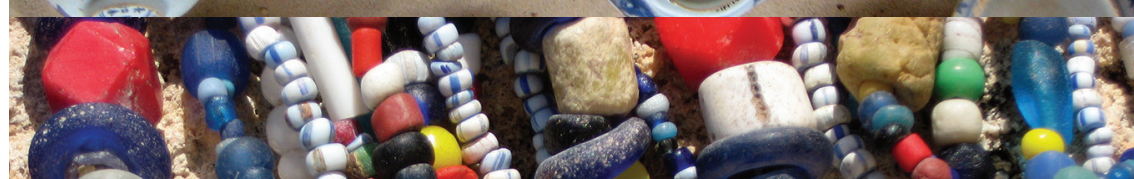
- Than

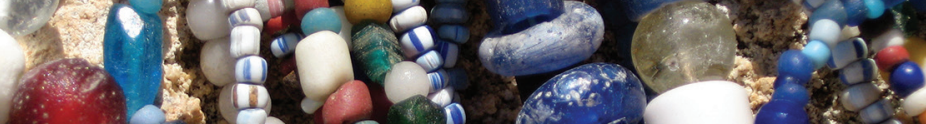
$-x+2$. 3

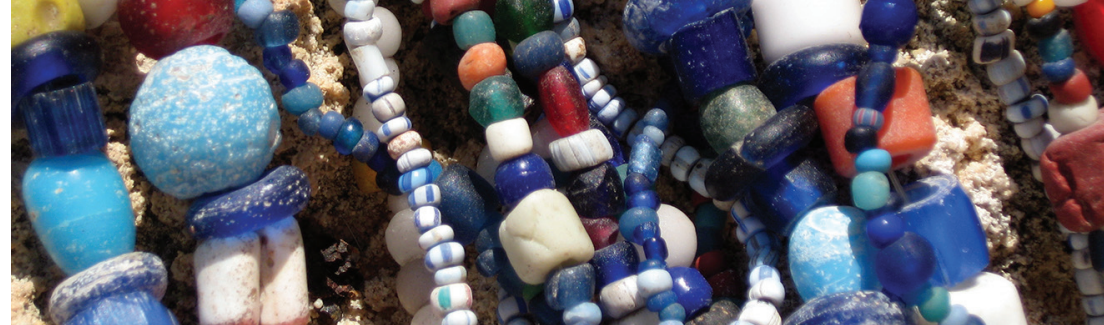
- 12.5. 4 -3 $125=$ - $x^{2}-1$ th

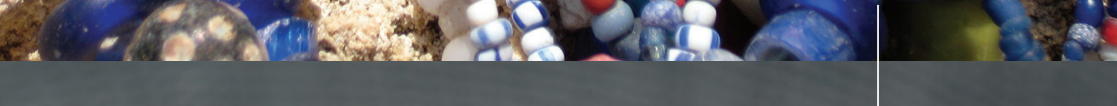




\section{UM SISTEMA DE COMUNICAÇÃO MUHIPITI PARA A ILHA DE MOÇAMBIQUE}

Elencadas algumas das potencialidades e vocações da llha enquanto Muhipiti, torna-se essencial compreender quais poderão ser as bases para o processo de criação da identidade visual desta marca-lugar.

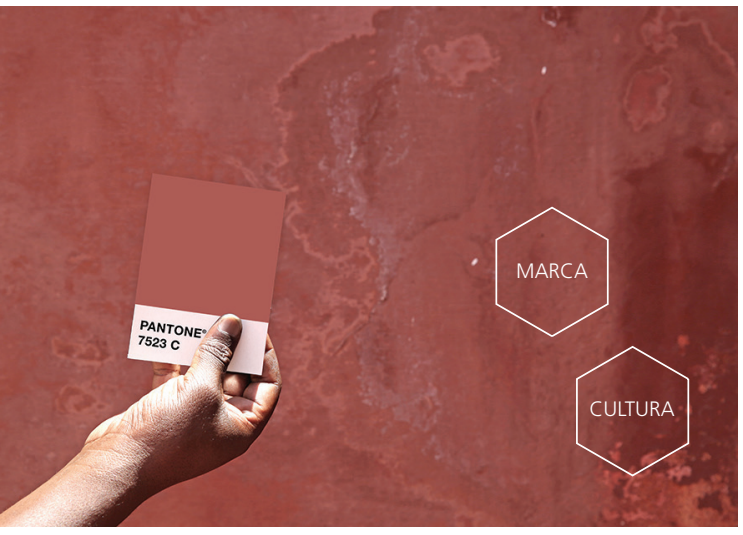

O procedimento criativo precisará de dar resposta a uma série de questões que terão de ser levantadas e analisadas de forma holística pelos diversos intervenientes, incluindo a comunidade, os atores e administradores locais.

O que tornará Muhipiti uma marca-lugar única? Quais os ingredientes essenciais que a permitirão definir, descrever, divulgar inequivocamente? Que cores, iconografia, padrões e texturas? O que poderá constituir um sistema de comunicação Muhipiti coerente nas suas várias dimensões de patrimónios tangíveis e intangíveis? Como promover e dignificar o seu estatuto de Património da Humanidade?

Tecnicamente, o desenho isolado de um logótipo será insuficiente. Ainda que essencial para a aplicação generalizada da marcalugar, este terá de fazer parte de um sistema de comunicação uno que padronize Muhipiti e tudo o que a ele se refira, criando uma linguagem visual coerente, forte e apelativa. 
Nesta análise deverão ter-se em conta fatores culturais específicos, assim como a elevada iliteracia, transmissão de tradição maioritariamente oral, desconhecimento ou difícil acesso a novas tecnologias de informação, características que poderão gerar equívocos de interpretação simbólica e concetual. Como refere Bruno Munari (2006: 10-11) "cada um vê o que conhece". Sugere-se, por isso, a criação de um sistema de comunicação objetivo, de fácil descodificação, que funcione tanto a nível local como internacional, evitando a utilização de códigos complexos para os quais os intervenientes não possuam elementos de descodificação.

Como conclusão-suspensão deste caminho, apresenta-se de seguida um receituário que visa ajudar a compreender imagética e conceptualmente Muhipiti e as suas especificidades. Poderá ser um ponto de partida para quem, de preferência num futuro próximo e refinando a receita, defina uma marca-lugar que dignifique e promova a pequena Ilha Muhipiti e o seu vasto e inefável património cultural.
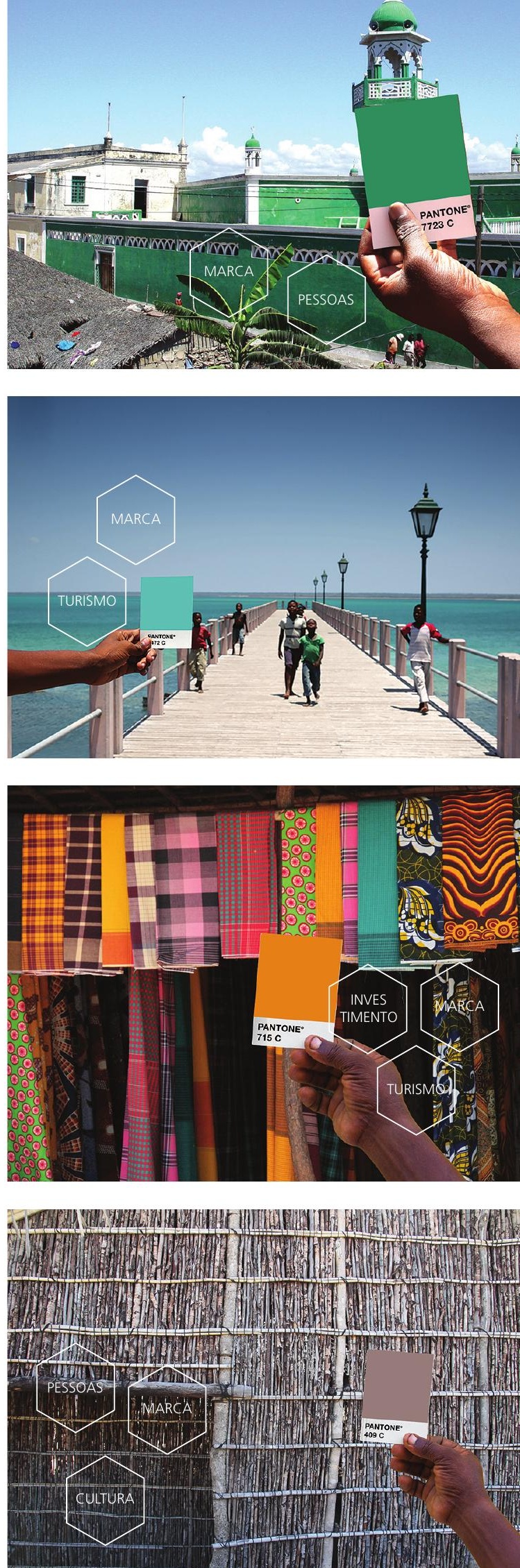

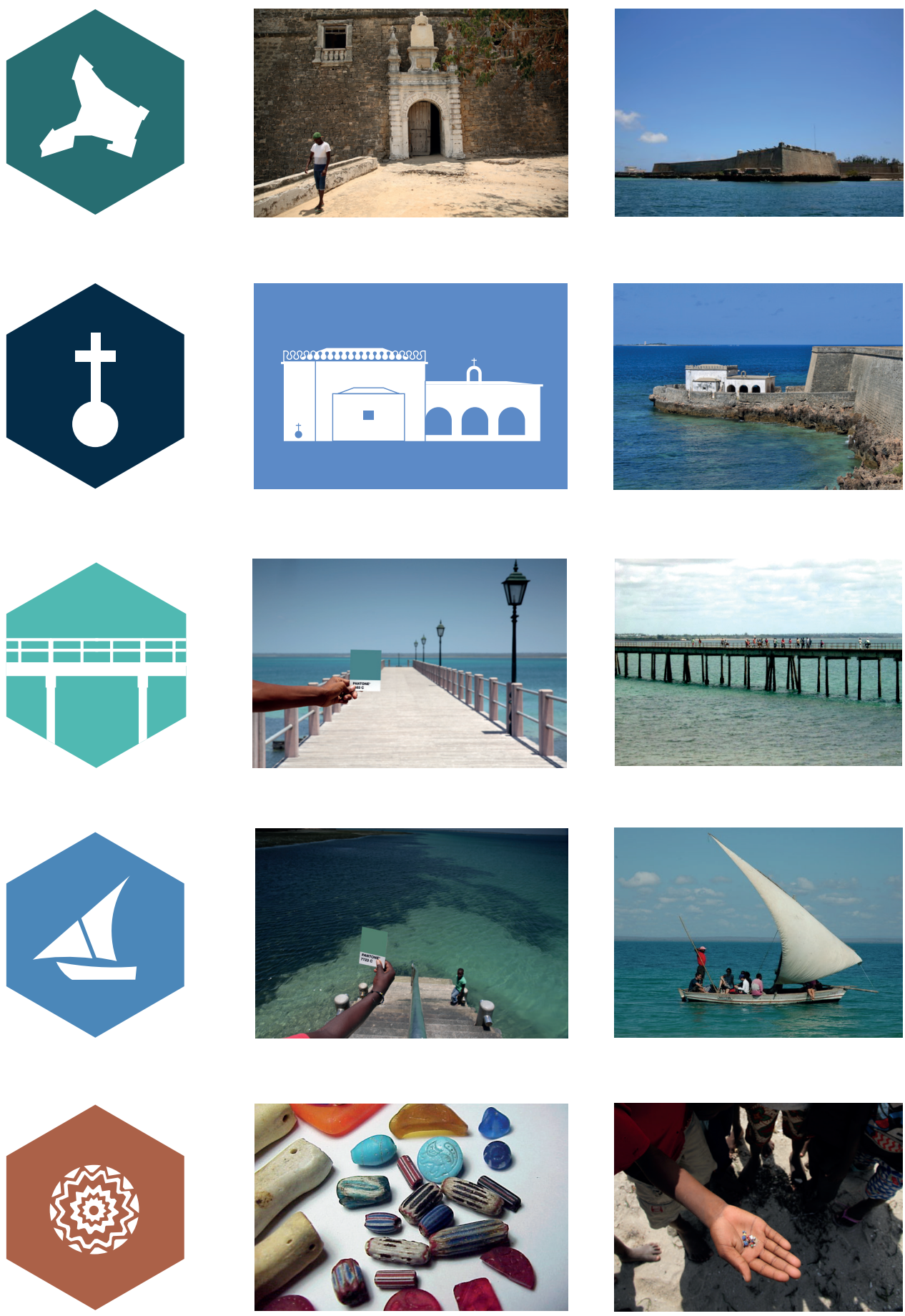

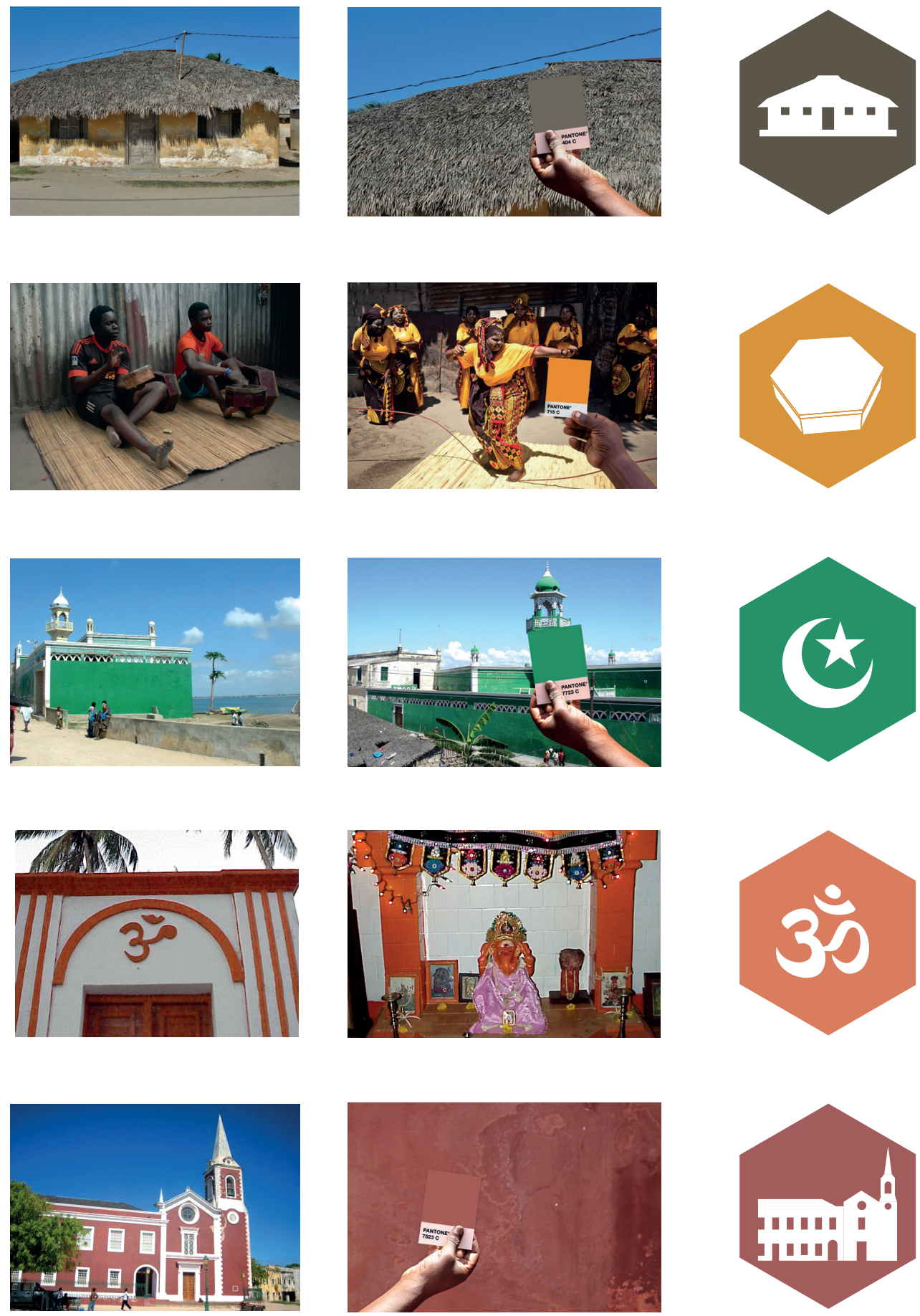


\section{INGREDIENTES PARA MUHIPITI}

Escolha-se uma ilha, não muito grande, com significativo passado histórico.

Tenha-se o cuidado de assegurar que uma fortaleza, alguns naufrágios, objetos e utensílios existam, para registar o passado.

Rodeie-se de verde-azul, em nuances que unam os céus e os mares.

Coloque-se suficientemente perto do continente, de forma a poder com ele comunicar. Erga-se uma ponte que permita o acesso de pessoas e veículos, em ambos os sentidos.

Retire-se pedra coral de metade e construam-se casas e edifícios na outra metade.

Aproveite-se do saque a cratera ferida, para aí construir os bairros tradicionais de macuti, e faça-se a ilha pulsar. Habite-se a ilha com diferentes culturas, credos, modos de estar, diferentes expressões artísticas, colocando todas em interação, mesclando até aos limites das suas identidades. Pintem-se as caras das mulheres de m'siro e vistam-se de capulanas garridas, contas e lenços que coroem o conjunto. 
Das árvores talhem-se dhows, barcos que permitam aliviar o monocromático dos dias, coreografando o ritmo das marés.

Polvilhe-se o mar de missangas e contas, que contem as histórias de viagens que por ali passaram. As marés encarregar-se-ão de as fazer falar.

Reúnam-se os fragmentos do passado e edifiquem-se os museus que permitam preservá-los no presente, continuando a narrá-los no futuro.

Mantenham-se vivas as tradições, danças de tufo, rituais e tudo o mais que torne esta ilha única.

Reclame-se o nome Muhipiti.

Leve-se Muhipiti para fora, ultrapassando os limites da ponte, coloque-se em aviões, navios, nas estórias dos que por ali passam, no artesanato que transportam consigo. Conte-se a história Muhipiti fora da ilha, inspirando novos viajantes a por ali passar, e outros inspirados por estes. Permita-se que Muhipiti tenha um futuro, que não se limite ao somatório da sua geografia, do seu património, do seu passado.

Muhipiti compreenderá quem é e tornar-se-á maior. 


\section{REFERÊNCIAS BIBLIOGRÁFICAS}

ANHOLT, Simon (2006) Competitive Identity: The New Brand Management for Nations, Cities and Regions. Basingstoke: Palgrave Macmillan.

KAVARATZIS, Mihalis (2004), "From City Marketing to City Branding: Towards a Theoretical Framework for Developing City Brands" , Place Branding 1 (1): 58-73. Consultado a 05.04.2017, em: https://doi.org/10.1057/ pb.2008.3.

KAVARATZIS, Mihalis (2009), "Cities and Their Brands: Lessons from Corporate Branding", Place Branding and Public Diplomacy 5 (1): 26-37. Consultado a 05.04.2017, em: https://doi.org/10.1057/ pb.2008.3.

Ministério da Cultura e Turismo (2017), Estratégia de Marketing do Turismo (2017-2021). Consultado a 05.04.2017, em:http://www. portaldogoverno.gov.mz/por/content/download/1436/12137/ version/1/file/Plano+Estrategico+Desenvolvimento+Turismo+lngl\%C3\%AAs.pdf.

MUNARI, Bruno (2006), Design e Comunicação Visual: contribuição para uma metodologia didática. São Paulo: Martins Fontes.

Serengeti Advisers and Acorn Tourism Consulting (2010), "Zanzibar Destination Marketing Strategy Final Report". Consultado a 05.04.2017, em: http://www. best-dialogue.org/publication/zanzibar-destinationmarket-strategy/.

UNESCO (2000), "The Stone Town of Zanzibar: WHC Nomination Documentation". Paris: UNESCO. Consultado a 05.04.2017, em: http://whc.unesco.org/uploads/nominations/173rev.pdf.

WADE, Derek J.: MWASAGA, B. C.; EAGLES, Paul F.J. (2001), "A history and market analysis of tourism in Tanzania", Tourism Management, 22 (1): 93-101. Consultado a 05.04.2017, em: https://doi.org/10.1016/ S0261-5177(00)00019-4.

WANJIRU, Evalyne (2006), "Branding African countries: A prospect for the future", Place Branding, 2 :84-95. Consultado a 05.04.2017, em: https://doi.org/10.1057/palgrave.pb.5990047.

YOUDE, Jeremy (2009), "Selling the State: State Branding as a Political Resource in South Africa", Place Branding and Public Diplomacy, 5 (2): 126-40. Consultado a 05.04.2017, em: https://doi.org/10.1057/ pb.2009.5. 


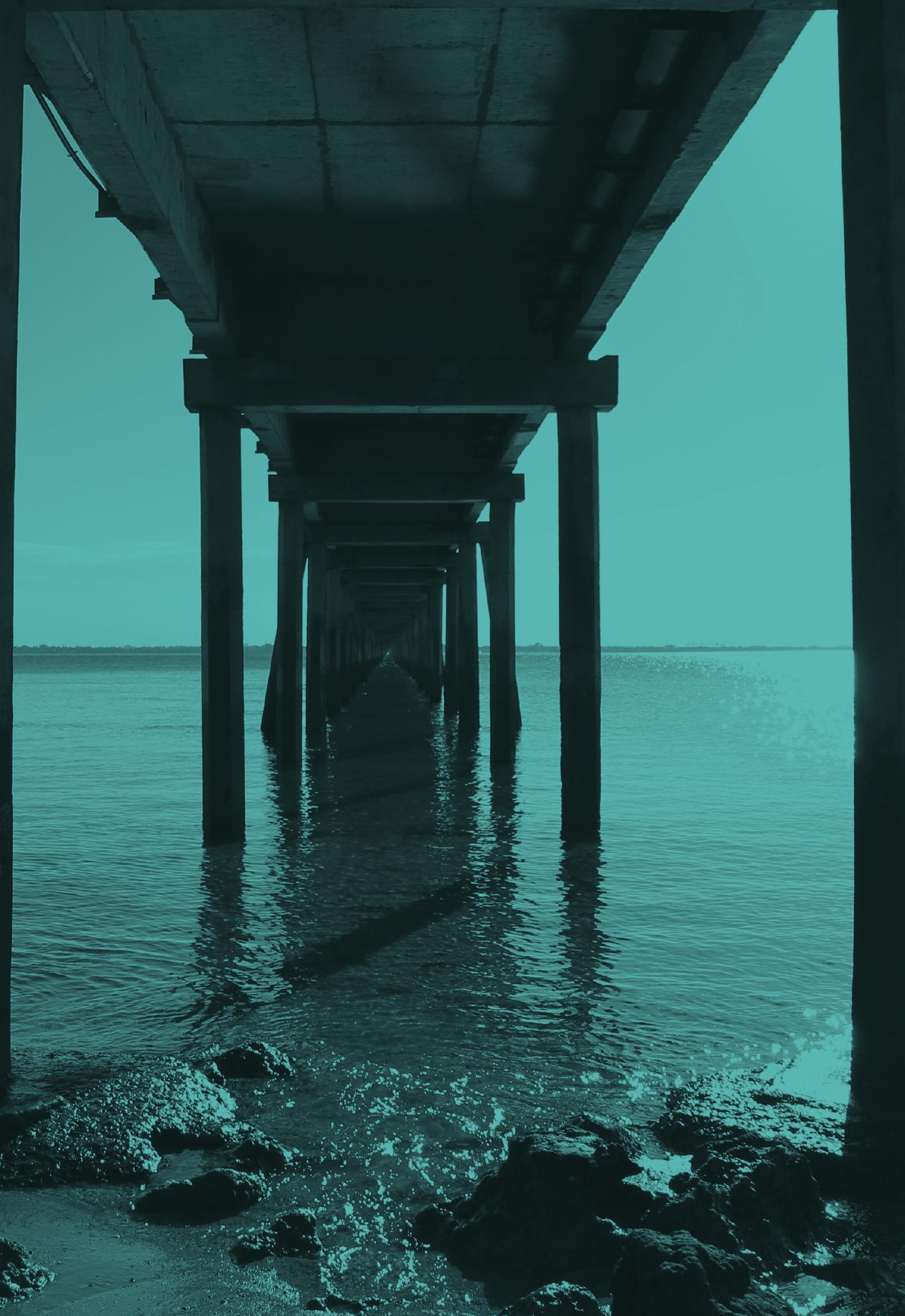




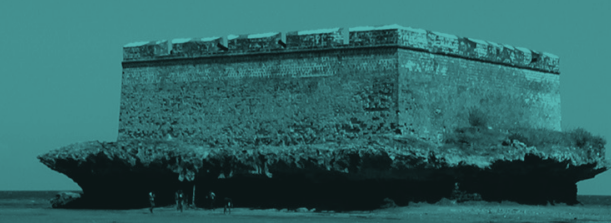

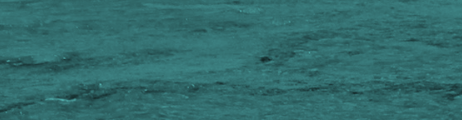

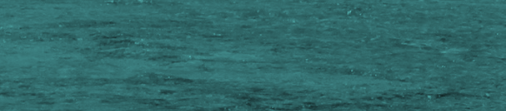

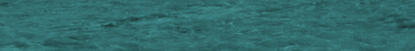

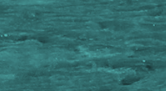

Q

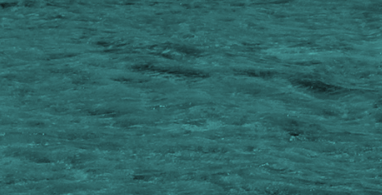

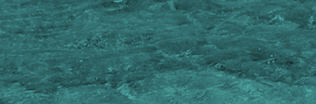

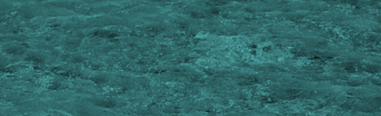

(1)

$200 x+3$

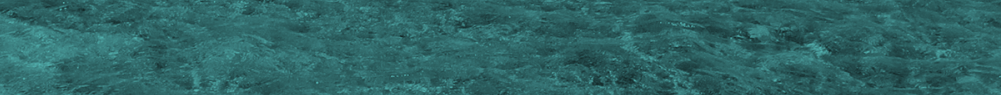

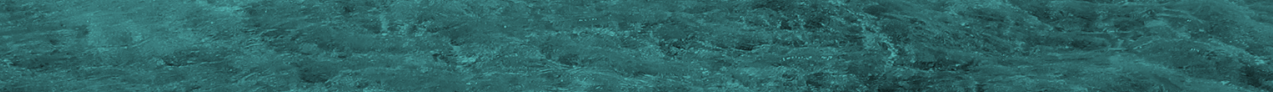
3

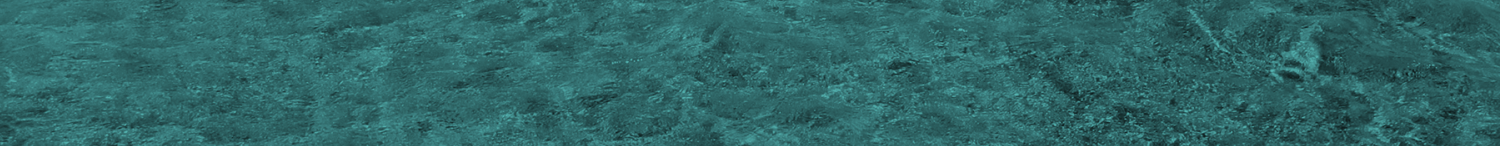
12:

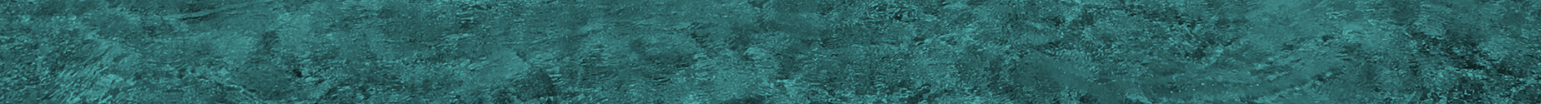

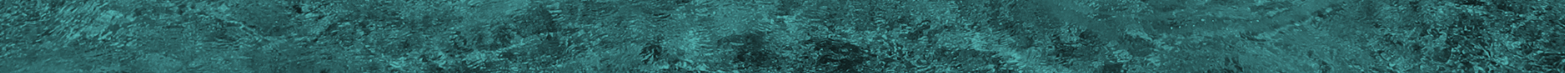

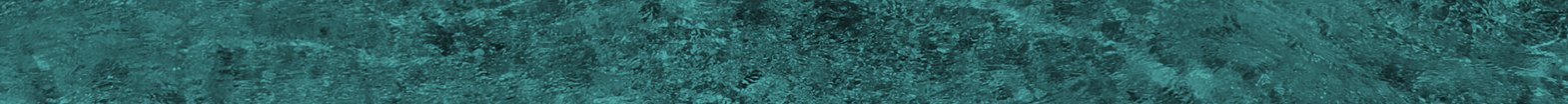

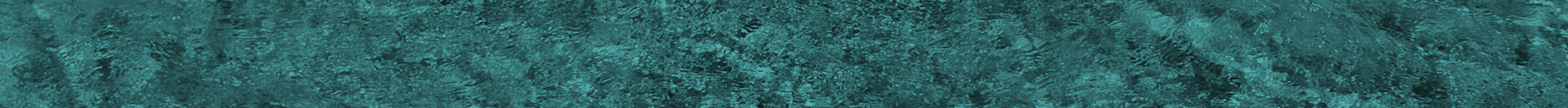

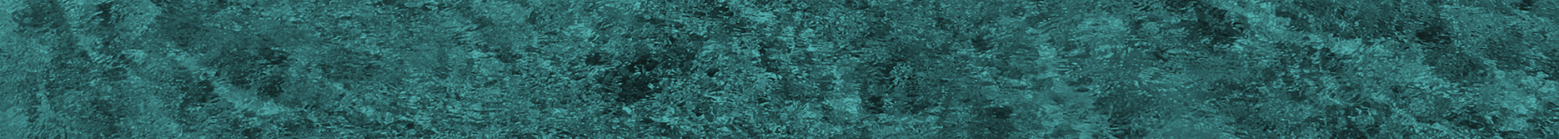

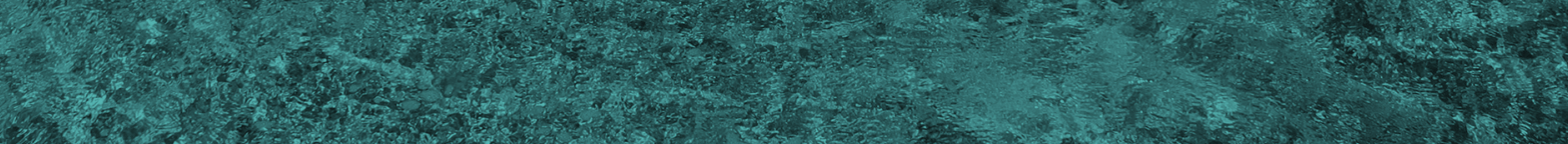

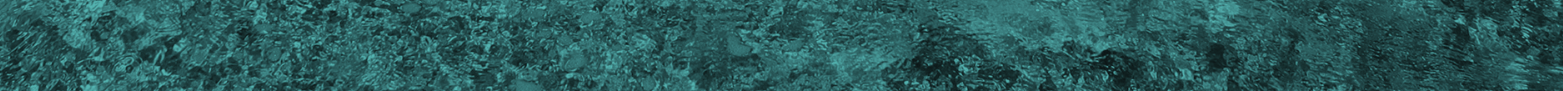
(25. (1) 1.7.

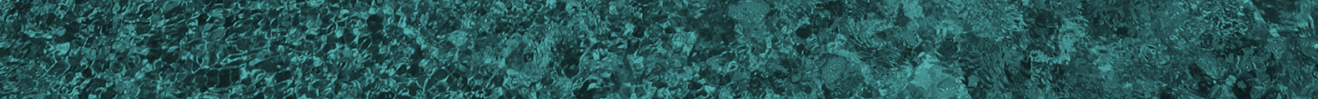

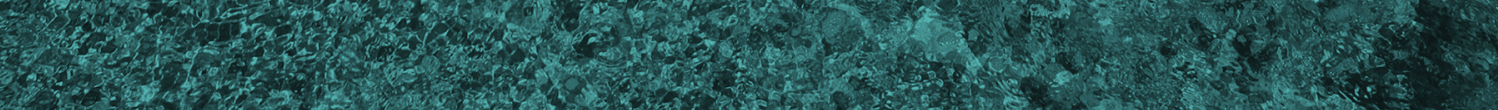




\section{ÍNDICE DE IMAGENS}

- Os nomes no final correspondem sempre à autoria ou fonte das imagens;

- As imagens sem autoria são dos organizadores da obra, exceto quando inseridas no texto relativo a uma oficina, situação em que também podem ser da respetiva autoria; - A data das imagens sem essa indicação é a dos 10 dias do evento.

p. 6

p. 9

p. 10

p. 15

p. 16

p. 18

p. 19

p. 20

p. 21

p. 23

p. 24

p. 26

p. 27

p. 29

p. 31

p. 36

p. 38

p. 39

p. 40

p. 41

p. 42

p. 44

p. 49

p. 50

Foto aérea, 2017. José Ribau Esteves.

Foto aérea, 1974. ARPAC, Maputo.

Casa Girassol, Ilha de Moçambique, 2017.

Encontro dos participantes, UniLúrio, Nampula, 2017.

Encontro dos participantes, UniLúrio, Adelino Gonçalves.

Visita à FAPF da UniLúrio, 2016.

Encontro dos participantes, UniLúrio.

Francisco Noa, no Oficinas de Muhipiti.

Isequiel Alcolete, em entrevista sobre o evento.

Habitante da Ilha.

Património do Estado, 2017.

Estátua deposta de Neutel de Abreu, Nampula, 2017.

Vila Algarve (antiga sede da PIDE), Maputo, 2016.

Estação Ferroviária da Beira. Arquivo dos autores.

Edifício na Ilha, 2016.

Estação Ferroviária de Maputo. Arquivo dos autores.

Casa da Vila do Ibo, 2001.

Panorâmica de Maputo, vista da Catembe, 2013.

Reabilitação da Casa Girassol, 2006. Jens Hougaard.

Reabilitação da Casa Girassol, 2006. Jens Hougaard.

Rua da Ilha, 2017.

Património do Estado, 2017.

Abertura oficial do Oficinas de Muhipiti, Conselho Municipal da llha de Moçambique.

Abertura oficial do Oficinas de Muhipiti, Conselho Municipal da llha de Moçambique. 
p. 51

p. 52

p. 53

p. 55

p. 55

p. 55

p. 55

p. 57

p. 59

p. 59

p. 62

p. 63

p. 65

p. 66

pp. 68 e 69

p. 71

p. 72

p. 73

p. 74

p. 75

p. 76

p. 77

p. 77

p. 78

p. 78

p. 78

p. 79

p. 79

p. 80

p. 80
Panorâmica sobre o Jardim da Memória e Casa Girassol. José Ribau Esteves.

Participantes, Casa Girassol.

Pontos de situação com a comunidade, Casa Girassol.

(superior) Refeição no pátio da Casa Girassol.

(centro, superior) Inauguração da exposição com os resultados provisórios.

(centro, inferior) Entrega de prémios da regata de dhows, com a presença da Secretária de Portugal, Maria Fernanda Rollo, e o Reitor da UniLúrio, Francisco Noa.

(inferior) Regata de dhows.

Localização das propostas apresentadas por cada oficina.

(superior) Cartaz, no CEDIM.

(inferior) Exposição com os resultados provisórios, no CEDIM.

Vista aérea sobre a cidade de macuti. José Ribau Esteves.

Alunos na cerimónia de encerramento, Salão Nobre do

Conselho Municipal da Ilha de Moçambique.

Equipa da oficina Estratégias para o desenvolvimento

sustentado.

Painel com os resultados provisórios da oficina.

Localização dos 15 Projetos Estruturantes.

Vista aérea sobre a cidade de macuti. José Ribau Esteves.

Mercado de rua.

A ponte com vista para o Djambesse, 2017.

Rua da cidade de macuti.

Pescador.

Anúncio.

(superior) Habitação da cidade de macuti.

(inferior) Grupo de tufo Estrela Vermelha.

(superior) Criança da Ilha.

(centro) Transporte terrestre Ilha-continente, 2017.

(inferior) Transporte marítimo llha-continente, 2017.

(superior) Transporte público interno, 2017.

(inferior) Habitação da cidade de macuti.

(superior) Construção de vala de drenagem de águas pluviais na cidade de macuti, 2006.

(centro) Projeto de habitação comunitária. 
p. 80

p. 81

p. 81

p. 82

p. 82

p. 83

p. 83

p. 83

p. 84

p. 84

p. 87

p. 88

p. 90

p. 91

p. 92

p. 95

p. 97

p. 99

p. 100

p. 101

p. 102

p. 105

p. 106

p. 108

p. 109

p. 110

p. 110

p. 110

p. 111

p. 111

p. 111

p. 112

p. 112

(inferior) Grupo de tufo Beira Mar.

(superior) Proposta para o mercado do peixe.

(inferior) Extração de sal no Lumbo, perto da Ilha, 2017.

(superior) Comércio de artesanato local.

(inferior) Requalificação de uma praia da Ilha.

(superior) Praia do Carramo (junto à fortaleza).

(centro) Largo junto à Praia do Carramo e fortaleza.

(inferior) Painel informativo em Sanculo, perto da Ilha, sobre zonas de risco. Projeto financiado pela UNHABITAT e OIKOS.

(superior) Edifício na llha. Oficina.

(inferior) Crianças a brincar na cidade de macuti.

Criança no pontão.

Embarcação naufragada junto ao pontão.

Painel informativo.

Mapa guia-monumentos da llha.

Reunião no GACIM, dezembro de 2016. Diretor Celestino

Gerimula, à esquerda, técnico do gabinete, à direita, e o

Coordenador-residente do Cluster da Cooperação Portuguesa

na llha, Vasco Ribeiro, ao centro.

Porta.

Cisterna da fortaleza.

Fortaleza vista do mar.

Porta de Armas da fortaleza.

Mesquita Grande.

Seteira da Capela de Nossa Senhora do Baluarte.

Equipa da Oficina Espaço Público.

Painel com os resultados provisórios da oficina.

Mesquita Grande a partir do mar. Jens Hougaard.

Esboço da proposta para o Espaço Nália.

(superior) Largo Luís de Camões.

(centro) Drenagem na cidade de macuti.

(inferior) Comércio local.

(superior) Avenida 25 de Junho, junto à cidade de macuti.

(centro) Vista aérea do Espaço Nália. José Ribau Esteves.

(inferior) Vista aérea da cidade de macuti. José Ribau Esteves.

(superior) Rua da cidade de macuti. Adelino Gonçalves.

(ao centro) Rua da cidade de macuti. Jens Hougaard. 
p. 112

p. 113

p. 113

p. 113

p. 114

pp. 115 e 116

p. 116

p. 118

p. 119

p. 121

p. 122

p. 124

p. 124

p. 125

p. 125

p. 125

p. 125

pp. 126 e 127

p. 127

p. 127

p. 127

p. 127

p. 127

p. 127

p. 128

p. 129

p. 130

p. 131

pp. 132 e 133

p. 133

p. 135

(inferior) Rua da cidade de macuti. Jens Hougaard.

(superior) Avenida Amílcar Cabral, cidade de pedra e cal.

(ao centro) Vista aérea da cidade de pedra e cal. José R. Esteves.

(inferior) Rua da cidade de pedra e cal.

Esboço da proposta para o Espaço Nália.

Corte esquemático da proposta para o Campo de S. Gabriel.

Esboço da proposta para o Campo de S. Gabriel.

Planta da proposta para o Campo de S. Gabriel.

Proposta para o Espaço Nália.

Equipa da oficina, Plano director de refuncionalização da fortaleza.

Painel com os resultados provisórios da oficina.

(superior) Fragmento de Mosanbiqve, em Plantas das cidades, portos e fortalezas, da conquista da India Oriental de João Teixeira Albernaz, 1634.

(inferior) Maqueta da fortaleza, existente no local, 2016.

(superior) Panorâmica do recinto da fortaleza.

(centro, superior) Acesso à plataforma superior da fortaleza.

(centro, inferior) Interior de um dos conjuntos edificados adjacentes à fortaleza.

(inferior) Recinto da fortaleza.

Problemas do estado de conservação do conjunto. Desenho da oficina apoiado na planta de José Forjaz (2008).

1. Erosão da base coralífera, 2016.

2. Destruição do muro pelo ciclone (2008), 2016.

3. Lixiviação das águas pluviais.

4. Instabilidade estrutural.

5. Infiltrações nos tetos e janelas.

6. Humidade das paredes adjacentes aos baluartes.

Corte com proposta para uma sala de aulas.

Interior da fortaleza.

Panorâmica da fortaleza. José Ribau Esteves.

A fortaleza na maqueta da llha.

Corte com proposta de intervenção.

Planta com proposta de intervenção.

Igreja de Nossa Senhora dos Remédios, na Cabaceira Grande, Mossuril. 
p. 136

p. 137

p. 138

p. 138

p. 138

p. 139

p. 140

p. 140

p. 143

p. 144

p. 145

p. 146

p. 147

p. 148

p. 148

p. 149

p. 149

p. 150

p. 151

p. 153

p. 154

p. 156
Detalhe da porta principal da Igreja de Nossa Senhora dos Remédios, na Cabaceira Grande, Mossuril, 2017.

Regata de dhows. Jens Hougaard.

(superior) Hospital. Jens Hougaard, 2010.

(centro) Casas da cidade de macuti. Jens Hougaard, 2010.

(inferior) A aguardar hora da oração junto à Mesquita Grande. Jens Hougaard, 2016.

Casa de Buanamade (colecionador de antiguidades). Jens Hougaard, 2016.

(superior) Ensaio da dança religiosa do Maulide. Jens Hougaard, 2016.

(inferior) Atuação do grupo de tufo Estrela Vermelha. Jens Hougaard, 2010.

Recinto da Fortaleza de São Sebastião.

Moradia na Rua dos Combatentes em conflito com a Lei de proteção. Jens Hougaard, 2016.

Sala de Projeto na FAPF da UniLúrio, Nampula, 2016.

Palestra de Jens Hougaard.

Panorâmica da cidade de macuti, a partir do minarete da Mesquita Grande da Ilha, 2013.

(superior) Parede de rocha coralífera da velha pedreira, no Bairro Macaribe. Jens Hougaard.

(inferior) Coqueiros e mangal na Cabaceira Pequena. Jens Hougaard, 2008.

(superior) Antigos documentos religiosos na família de Saide Amur e sua mãe. Jens Hougaard, 2016.

(inferior) Dança de tufo. Jens Hougaard, 2014.

Mapa da Cidade da Ilha de Moçambique, Ministério da Administração Estatal de Moçambique. Jens Hougaard, 2010.

Mercado debaixo da grande n'tompe-tompe (ficus benghalensis), na ponta da Ilha. Jens Hougaard, 2015.

Equipa da oficina Plano para centro comunitário na faixa central da Ilha.

Painel com os resultados provisórios da oficina.

Excerto da planta Província de Moçambique / Ilha de Moçambique / Escala 1:2000, Serviços Geográficos e Cadastrais, 1957. 
p. 157

pp. 158 e 159

p. 158

p. 158

p. 158

p. 159

p. 160

p. 162

p. 162

p. 162

p. 163

p. 163

p. 163

p. 163

p. 164

p. 165

p. 165

p. 166

p. 166

p. 167

p. 169

p. 170

p. 172

p. 174

p. 176

p. 177

p. 178
Praça 16 de Junho, com o Hospital ao fundo.

Corte com proposta.

(superior, esquerda) Excerto de fotografia aérea da llha de Moçambique, 1974. ARPAC, Cx. "Nampula, XI, Monumentos e Locais Históricos, 2".

(superior, direita) Excerto de fotografia aérea da llha de Moçambique, 1974. ARPAC, Cx. "Nampula, XI, Monumentos e Locais Históricos, 2".

(inferior) Representação esquemática da evolução da ocupação na área de estudo.

Representação tridimensional da área de estudo.

Futuras instalações da Associação dos Amigos e Naturais da Ilha de Moçambique.

(superior) Artesanato e relíquias da Ilha.

(centro) Mercado de rua.

(inferior) Habitantes a jogar n'txuva.

(superior) Antigo Matadouro Municipal.

(centro, superior) Antiga sede e instalações desportivas do Sporting Clube de Moçambique.

(centro, inferior) Mercado de Nália.

(inferior) Escola Primária 16 de Junho, destruída pelo ciclone.

Esquiço com proposta de arborização e reorganização das cotas do terreno a este da Praça 16 de Junho.

(superior) Esquiço com proposta de edifício para restauração, aberto sobre a Praça 16 de Junho.

(inferior) Mercado de Peixe O Sarrero.

(superior) Corte com proposta.

(inferior) Planta com proposta.

Espacialização da proposta de rede do "centro comunitário".

Equipa da oficina Casas de Macuti.

Painel com os resultados provisórios da oficina.

Vista dos Bairros Esteu e Lithine.

Sessão pública com a população e o secretário do Bairro Lithine.

Cozinha numa casa do Bairro Lithine.

"Escrita desenhada" do trabalho de campo.

Construção de uma cobertura em macuti. 
p. 179

p. 180

p. 181

p. 182

p. 183

p. 184

p. 185

p. 186

p. 187

p. 187

p. 189

p. 191

p. 192

p. 193

p. 194

p. 195

p. 196

p. 198

p. 199

p. 199

p. 200

p. 201

p. 203

p. 204

p. 205

p. 207
Levantamento de casa de macuti no Bairro de Lithine.

"Escrita desenhada" do trabalho de campo.

Casa no Bairro de Lithine.

"Escrita desenhada" do trabalho de campo.

Proposta para processo evolutivo de uma casa tipo do Bairro de Lithine: sanitários e quarto(s); Uma casa, uma árvore.

Proposta do processo evolutivo de casa de seis compartimentos para nove.

Família no exterior da sua casa, Bairro de Lithine.

Proposta do processo evolutivo, a quatro níveis.

(superior) Corte com proposta.

(inferior) Maquetas com propostas em dois tipos distintos.

Sessão pública com a população e o secretário do Bairro

Lithine.

Crianças.

Pintura na parede de uma casa de macuti, no Bairro de Lithine.

Pinturas Rupestres da Província de Nampula. Contribuição para o conhecimento da arqueologia entre os rios Lúrio e Ligonha - província de Nampula, de Leonardo Adamowicz, 1988.

Pinturas Rupestres do abrigo de Musé. Contribuição para o conhecimento da arqueologia entre os rios Lúrio e Ligonha província de Nampula, de Leonardo Adamowicz, 1988.

Roteiro de Lisboa a Goa, de D. João de Castro, 1882.

Peça de teatro sobre a escravatura, Jardim da Memória. Jens Hougaard, 2016.

Celebração do nascimento do profeta. Jens Hougaard, 2014.

(superior) Escritos do Alcorão. Jens Hougaard, 2016.

(inferior) Cobertura em macuti. Jens Hougaard, 2014.

Palestra de Momade Ali.

Comércio de rua. Jens Hougaard, 2016.

Baía do Mossuril com a llha ao fundo.

Baía do Mossuril com a llha ao fundo.

Crianças a brincar numa praia, 2017.

Ficus benghalensis ( $n$ tompe-tompe, em língua local) na ponta da llha. 
p. 209

p. 210

p. 211

p. 212

p. 212

p. 213

p. 214

p. 215

p. 217

p. 218

pp. 220 e 221

p. 222

p. 224

p. 224

p. 224

p. 225

p. 226

p. 226

p. 226

p. 227

p. 229

p. 231

p. 232

p. 235

p. 236

p. 238

p. 239

p. 240

p. 241

p. 241

p. 241

Limpeza das praias, com a participação do autor. João Vaz.

Poluição nas praias da llha. João Vaz, 2016.

Limpeza das praias da llha. João Vaz, 2016.

(superior) Ação de sensibilização da população para a separação do lixo. João Vaz, 2016.

(inferior) Ação de sensibilização da população para a separação do lixo. João Vaz, 2016.

Palestra de João Vaz.

Recolha de lixo por crianças. João Vaz, 2016.

Anúncio do Município para uma llha limpa.

Equipa da oficina Centro de Interpretação de Muhipiti. .

Painel com os resultados provisórios da oficina.

Panorâmica da llha. José Ribau Esteves.

Grupo de tufo Beira Mar, entrevistado pela oficina.

(superior) Fruto e castanha do caju.

(centro) Palácio de S. Paulo..

(inferior) Cozinheiras da llha.

Planta da ilha e perspectiva da cidade de Moçambique, de J.

Faustino, 1835.

(superior) Grupo de tufo Estrela Vermelha.

(centro) Habitante da Ilha com m'siro na cara.

(inferior) Venda de capulanas na llha.

Maquetas da llha e da fortaleza, expostas no atual espaço do CEDIM, no edifício do Conselho Municipal.

Composição gráfica.

Estrelas do mar numa praia, 2017.

Criança com estrela do mar, 2017.

Esquema hexagonal, baseado em Anholt (2006: 25-26), para a criação de uma identidade competitiva para a Ilha.

Vista da llha.

Intervenção de um habitante numa das palestras.

Atuação de um grupo de tufo na llha. Jens Hougaard.

Banco de coral, com a fortaleza ao fundo.

(superior) Vista da baía do Mossuril num dhow da llha. Ilha Blue (http://ilhablue.com).

(centro) I/ha Blue (http://ilhablue.com).

(inferior) Genito Magic Tour (www.genitomagictour.com). 
p. 242

p. 243

p. 243

p. 243

p. 244

p. 244

p. 244

p. 246

p. 247

p. 247

p. 247

p. 248

p. 248

p. 248

p. 249

p. 249

p. 249

p. 249

p. 250 e 251

pp. 252 e 253

p. 255

p. 256

p. 266

p. 272

p. 278
Alunos do Oficinas a montarem a maqueta. Adelino Gonçalves.

(superior) Vendedores do fruto do caju, no Namialo.

(centro) Fruto e castanha do caju.

(inferior) Vendedores da castanha do caju, no Namialo.

(superior) Espécies piscícolas das águas envolventes da llha.

(centro) Espécies de búzios das águas envolventes da Ilha.

(inferior) Jovens pescadores da llha.

Peça de porcelana Ming encontrada num naufrágio ao largo da Ilha, atualmente exposta no Museu da Ilha.

(superior) Peças de porcelana Ming encontradas num naufrágio ao largo da Ilha, atualmente expostas no Museu da Ilha. Jens Hougaard, 2010.

(centro) Colares de missangas antigas encontradas nas praias. Jens Hougaard, 2010.

(inferior) Missangas antigas encontradas nas praias.

(superior) Parede do Museu da llha.

(centro) Parede em pedra de coral numa casa da Ilha.

(inferior) Parede de pedra e cal numa casa da Ilha.

(superior) Mesquita Grande.

(centro, superior) Pontão.

(centro, inferior) Venda de capulanas.

(inferior) Paramento em madeira de mangal (laca-laca, em língua local), numa casa da cidade de macuti.

Relação gráfica de algumas referências da Ilha com os ícones criados. Fotos de vários autores.

Composição gráfica com perfil extraído da Planta da ilha e perspectiva da cidade de Moçambique, de J. Faustino, 1835.

Vista inferior da ponte da Ilha.

Fortim de São Lourenço.

Regata de dhows.

Fortim de São Lourenço. José Ribau Esteves.

Projeção de filme no Hospital. 2017. 

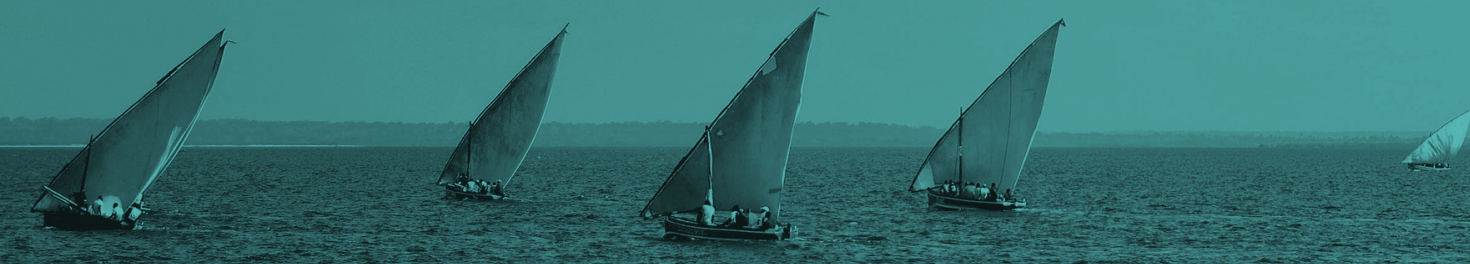

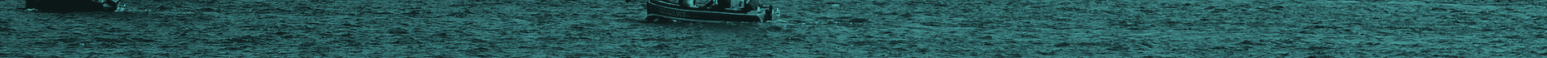

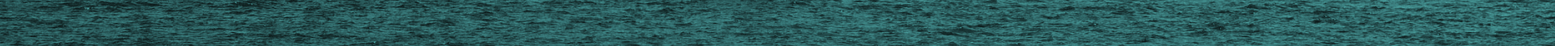

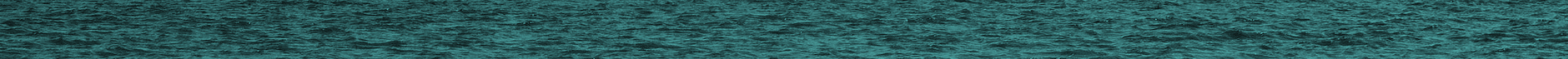

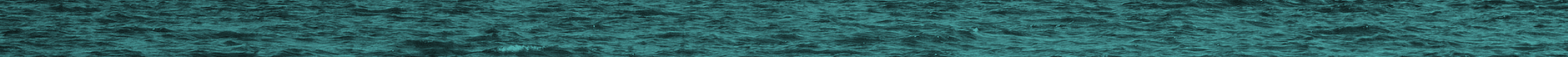

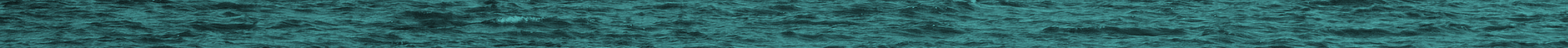

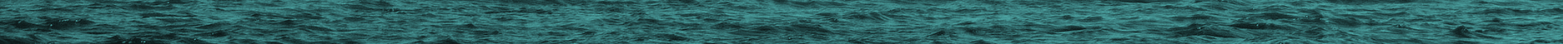

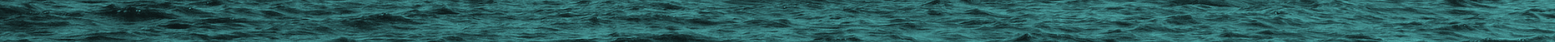

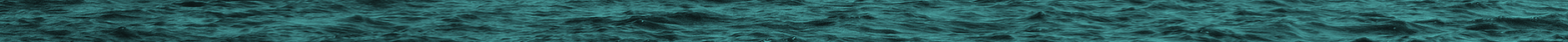

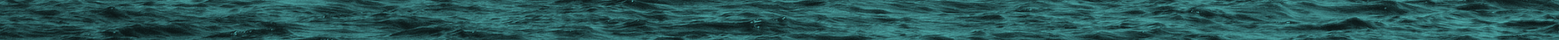

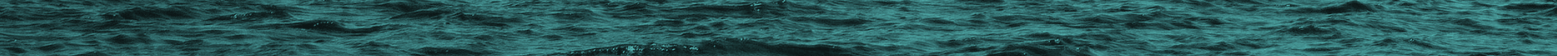

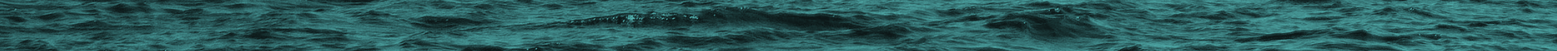
Gor.

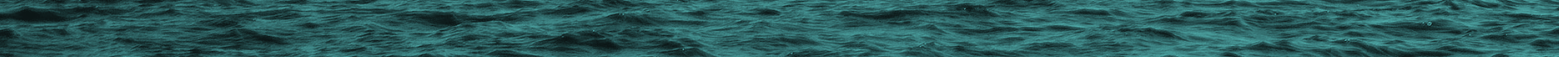

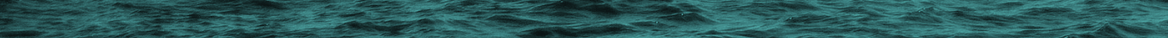
I Fis

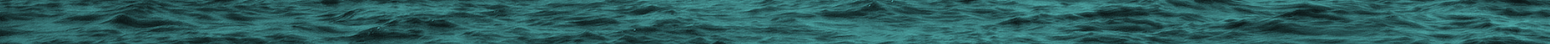

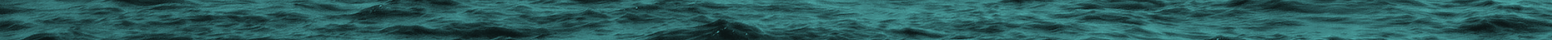

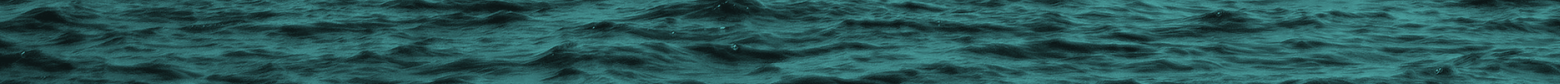

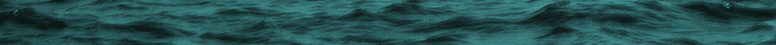




\section{NOTAS BIOGRÁFICAS}

Aldevina Brito dos Santos é arquiteta pela Faculdade de Arquitetura e Planeamento Físico da Universidade Lúrio, na qual é docente e onde frequenta o mestrado em Desenvolvimento do Território e Gestão Urbana. Fez parte da ONG Girl Move Foundation, programa comunitário focado na motivação, liderança e empreendedorismo social da mulher e adolescente.

António de Amurane é arquiteto pela Faculdade de Arquitetura e Planeamento Físico da Universidade Lúrio, na qual é docente e onde frequenta o mestrado em Planeamento e Gestão de Assentamentos Informais. Foi docente na Academia Militar Marechal Samora Machel e consultor do programa das Nações Unidas para os Assentamentos Humanos (UN-Habitat).

Bernardo João Xavier é arquiteto pela Faculdade de Arquitetura e Planeamento Físico da Universidade Eduardo Mondlane. É docente na Faculdade de Arquitetura e Planeamento Físico da Universidade Lúrio, onde frequenta o mestrado em Desenvolvimento do Território e Gestão Urbana. Foi colaborador no projeto Corredor de Nacala; no projeto de Cooperação Técnica Internacional Brasil-Moçambique; e nas oficinas de elaboração do Plano Base de Nampula, promovidas pela Cátedra da Unesco, em parceria com a Universidade Lúrio.

Fernando Pires é arquiteto pela Faculdade de Arquitetura e Urbanismo da Universidade de Sarajevo (equivalência pela Faculdade de Arquitetura da Universidade Técnica de Lisboa), mestre em desenho urbano pelo Instituto Universitário de Lisboa e doutor em Patrimónios de Influência Portuguesa, ramo de Arquitetura e Urbanismo, pela Universidade de Coimbra, com a dissertação Há vida além da costa. Urbanidades em Cabo Verde no século XIX (2017).

Francisco Noa, Reitor da Universidade Lúrio, é doutorado em Literaturas Africanas de Língua Portuguesa pela Universidade Nova de Lisboa. Ensaísta, professor de Literatura Moçambicana na Universidade Eduardo Mondlane, investigador associado do Centro de Estudos Sociais da Universidade de Coimbra, foi diretor e investigador do Centro de Estudos Sociais Aquilo de Bragança. Professor convidado, orientador e examinador de teses em universidades moçambicanas e estrangeiras, assumiu vários cargos de gestão em instituições de ensino superior. A sua investigação atual debruça-se sobre os temas de colonialidade, nacionalidade e transnacionalidade literária, a literatura como conhecimento e o diálogo intercultural no Oceano Índico, a partir da literatura. 
Helena Soares Rebelo é designer de Comunicação pela Escola Universitária das Artes de Coimbra. Em Moçambique, foi docente na Faculdade de Educação e Comunicação da Universidade Católica de Moçambique (Nampula) e designer residente do Gabinete de Comunicação e Eventos: Criativa, Sociedade de Serviços Lda. (Maputo). Tem colaborado com os projetos Patrimónios de Influência Portuguesa, do Instituto de Investigação Interdisciplinar, e a ERC Memoirs, Filhos de Império e Pós-Memórias Europeias do Centro de Estudos Sociais, ambos da Universidade de Coimbra.

Isequiel Alcolete é arquiteto e pós-graduado em Planeamento e Gestão de Assentamentos informais pela Faculdade de Arquitetura e Planeamento Físico da Universidade Eduardo Mondlane. É diretor e docente da Faculdade de Arquitetura e Planeamento Físico da Universidade Lúrio. Participou na elaboração do Plano de Estrutura Urbana do Município de Maputo através do Centro de Estudos do Desenvolvimento do Habitat da Universidade Eduardo Mondlane. Trabalhou para a Agência Espanhola de Cooperação Internacional para o Desenvolvimento na Implementação do Plano Parcial de Urbanização do Distrito do Ibo; e na Direção Provincial de Obras Públicas e Habitação, Província de Cabo Delgado, como coordenador para elaboração do Projeto de Pequeno Sistema de Abastecimento de Água para o Distrito de Palma e Ibo.

Jaime Almeida Aguacheiro é arquiteto pela Faculdade de Arquitetura e Planeamento Físico da Universidade Eduardo Mondlane, onde frequenta o mestrado em Planeamento e Gestão de Assentamentos Informais. É docente e membro do Conselho Universitário na Faculdade de Arquitetura e Planeamento Físico da Universidade Lúrio, onde foi diretor científico. Foi diretor do CESAP daquela faculdade. É investigador do Centro de Estudos e Documentação da llha de Moçambique e fez parte da equipa técnica da UN-Habitat, que assistiu aos municípios atravessados pelo corredor de Nacala, no âmbito do planeamento urbano.

Jens Hougaard é arquiteto pela Escola de Arquitetura de Aarhus (Dinamarca). Foi cooperante no Ministério de Educação e Cultura de Moçambique (1977) onde trabalhou num programa de construção de escolas primárias nas Zonas Libertadas no norte do país. Em 1980 foi destacado para a llha de Moçambique, onde dirigiu o Gabinete de Restauro até 1985. O Relatório Ilha de Moçambique 1982-85 (conhecido como Livro Azul) corresponde a um resumo das investigações realizadas. Em 1990 coordenou a elaboração do dossier da candidatura da llha de Moçambique à inscrição na Lista do Património Mundial da UNESCO. Regressou a Moçambique em 1993 onde trabalhou em projetos de serviços sociais em zonas rurais afetadas pela guerra e, em 2009, à llha de Moçambique para trabalhar como assessor técnico no recém-criado Gabinete de Conservação da Ilha de Moçambique. Durante os últimos anos foi docente na Faculdade de Arquitetura e Planeamento Físico na Universidade Lúrio e diretor do Centro de Estudos da llha de Moçambique. 
João Vaz é engenheiro mecânico pela Universidade de Coimbra. Tem centrado a sua atividade em questões ambientais, tendo elaborado a componente da estratégia ambiental do Plano Estratégico de Desenvolvimento e Agenda21 Local. Em Portugal e em São Tomé e Príncipe ministrou formação a funcionários, técnicos locais e decisores políticos. Através da liderança de vários projetos de resíduos na Europa e em África, adquiriu uma visão global dos problemas e respetivas soluções. Em Moçambique, colaborou com a UCCLA na implementação do projeto de compostagem descentralizada da llha de Moçambique (20162017), formando ecogestores e construindo compostores no âmbito da sua produção, sendo ainda responsável pela elaboração de Planos de Gestão de Resíduos em Nampula, Monapo e Dondo.

Júlio Carrilho é arquiteto doutorado e poeta. Aposentado desde 1993, foi professor na Faculdade de Arquitetura e Planeamento Físico da Universidade Eduardo Mondlane e investigador do Centro de Estudos e Desenvolvimento do Habitat. Com vasta experiência de direção, desempenhou funções de Ministro das Obras Públicas e Habitação no Governo de Transição de Moçambique e no primeiro Governo da República de Moçambique (1974-1975 e 1975-1987). Foi Presidente do Conselho de Administração do Fundo de Desenvolvimento Artístico e Cultural (1989-1994) e membro da Comissão Nacional de Moçambique da UNESCO (1990).

Lisandra Franco de Mendonça é arquiteta pela Faculdade de Arquitetura da Universidade do Porto, especialista em Restauro de Monumentos pela Scuola di Specializzazione in Restauro dei Monumenti da Universidade de Roma - La Sapienza e doutora em Patrimónios de Influência Portuguesa, ramo de Arquitetura e Urbanismo, pela Universidade de Coimbra em cotutela com a Universidade de Roma - La Sapienza, com a dissertação Conservação da arquitetura e do ambiente urbano modernos: a Baixa de Maputo (2016).

Luís Lage é arquiteto doutorado. Aposentado, foi diretor da Faculdade de Arquitetura e Planeamento Físico da Universidade Eduardo Mondlane e docente na linha temática de Representação Gráfica. Na área de projeto, trabalhou no Centro de Estudos do Desenvolvimento do Habitat daquela faculdade e com o arquiteto José Forjaz.

Luísa Trindade é historiadora e professora no Departamento de História, Estudos Europeus, Arqueologia e Artes da Faculdade de Letras e investigadora no Centro de Estudos Sociais da Universidade de Coimbra. É docente no curso de doutoramento Patrimónios de Influência Portuguesa do Instituto de Investigação Interdisciplinar da Universidade de Coimbra. 
Margarida Relvão Calmeiro é arquiteta doutorada em arquitetura pelo Departamento de Arquitetura da Faculdade de Ciências e Tecnologia da Universidade de Coimbra com a dissertação Urbanismo antes dos Planos: Coimbra 1834-1934 (2015). É Professora Convidada do mesmo departamento, onde leciona unidades curriculares de urbanismo e rege um Seminário de Investigação, sendo ainda co-coordenadura do Mestrado de Reabilitação de Edifícios do Departamento de Engenharia Civil. Desenvolve investigação na área da teoria e história do urbanismo.

Milton Novela é historiador e docente na Faculdade de Arquitetura e Planeamento Físico da Universidade Lúrio, na qual onde se encontra a frequentar o mestrado em Desenvolvimento do Território e Gestão Urbana. É diretor do Centro de Estudos e Documentação da llha de Moçambique.

Momade Amisse Ali é historiador pela Universidade Eduardo Mondlane e mestre em Ciência da Informação pela Escola de Ciência da Informação, da Universidade Federal de Minas Gerais. É docente e diretor de Serviços de Documentação na Universidade Lúrio. É doutorando em Ciências de Educação, com uma linha de pesquisa em Tecnologias de Informação e Comunicação e e-Educação.

Nuno Lopes é mestre em arquitetura pela Escola de Artes da Universidade de Évora e doutor em Patrimónios de Influência Portuguesa, ramo de Arquitetura e Urbanismo, pela Universidade de Coimbra, com a dissertação O Sistema Defensivo de Goa (1510-1660): influência na composição do território contemporâneo (2017). É, desde 2015, bolseiro de Gestão de Ciência e Tecnologia do Instituto de Investigação Interdisciplinar da Universidade de Coimbra.

Nuno Simão Gonçalves é mestre em arquitetura pela Faculdade de Ciências e Tecnologia da Universidade de Coimbra, investigador júnior no Centro de Estudos Sociais da Universidade de Coimbra, desde 2013, e doutorando em Patrimónios de Influência Portuguesa, ramo de Arquitetura e Urbanismo, pela Universidade de Coimbra, onde está a desenvolver a dissertação Do caniço ao cimento: a evolução urbana da capital de Moçambique (1892-1992), com uma bolsa de doutoramento da FCT.

Renata Malcher de Araujo é professora do Departamento de Artes e Humanidades da Faculdade de Ciências Humanas e Sociais da Universidade do Algarve e investigadora integrada do CHAM, Centro de Humanidades da Faculdade de Ciências Sociais e Humanas da Universidade Nova de Lisboa. É docente no curso de doutoramento Patrimónios de Influência Portuguesa da Universidade de Coimbra. 
Solange Macamo é arqueóloga doutorada pelo Departamento de Arqueologia e História Antiga da Universidade de Uppsala (Suécia), docente e regente no Curso de Licenciatura em Arqueologia e Gestão do Património Cultural da Universidade Eduardo Mondlane. É responsável pela coordenação de projetos sobre a Política de Monumentos, Regulamento sobre a Gestão de Bens Culturais Imóveis, entre outros. Foi diretora nacional do Património Cultural do Ministério da Cultura e depois Cultura e Turismo (2010-2017).

Valdemiro Aboo é geógrafo pela Universidade Pedagógica de Moçambique e especialista em Ciências e Tecnologia do Ambiente, área de Riscos: Avaliação e Gestão Ambiental, pela Faculdade de Ciências da Universidade do Porto. É docente na Faculdade de Arquitetura e Planeamento Físico da Universidade Lúrio. Tem participado em diversos eventos e formações científicas nacionais e internacionais sobre temáticas de planeamento urbano e gestão ambiental.

Victor Mestre é arquiteto pela Escola Superior de Belas Artes de Lisboa, mestre em Recuperação do Património Arquitetónico e Paisagístico pela Universidade de Évora, detentor do diploma de Estudos Avançados em Teoria e Prática de Reabilitação Urbana e Arquitetónica pela Universidade de Sevilha, e aguarda a realização das provas de doutoramento em Patrimónios de Influência Portuguesa pela Universidade de Coimbra, ramo de Arquitetura e Urbanismo, com a dissertação Arquitetura vernacular em Goa. Com Sofia Aleixo, fundou a vmsa arquitectos (1991), onde tem desenvolvido diversos tipos de projetos e obras nacionais e internacionais. Foi arquiteto da Direção Regional de Monumentos de Lisboa (1994-2000) e Diretor do Gabinete de Salvaguarda do Património da Direcção-Geral de Edifícios e Monumentos Nacionais (2000-2003).

Walter Rossa é arquiteto, professor catedrático do Departamento de Arquitetura e investigador no Centro de Estudos Sociais da Universidade de Coimbra. É co-coordenador do curso de doutoramento Patrimónios de Influência Portuguesa da Universidade de Coimbra. Professor convidado de diversas universidades em diferentes países, tem desenvolvido investigação e publicado em várias línguas nas áreas da História da Arquitetura e do Urbanismo, bem como da salvaguarda do Património e Planeamento e Ordenamento do Território, em duas linhas de grande reciprocidade: uma dedicada à urbanística de influência portuguesa; outra sobre o planeamento urbano em contextos com relevância patrimonial. 


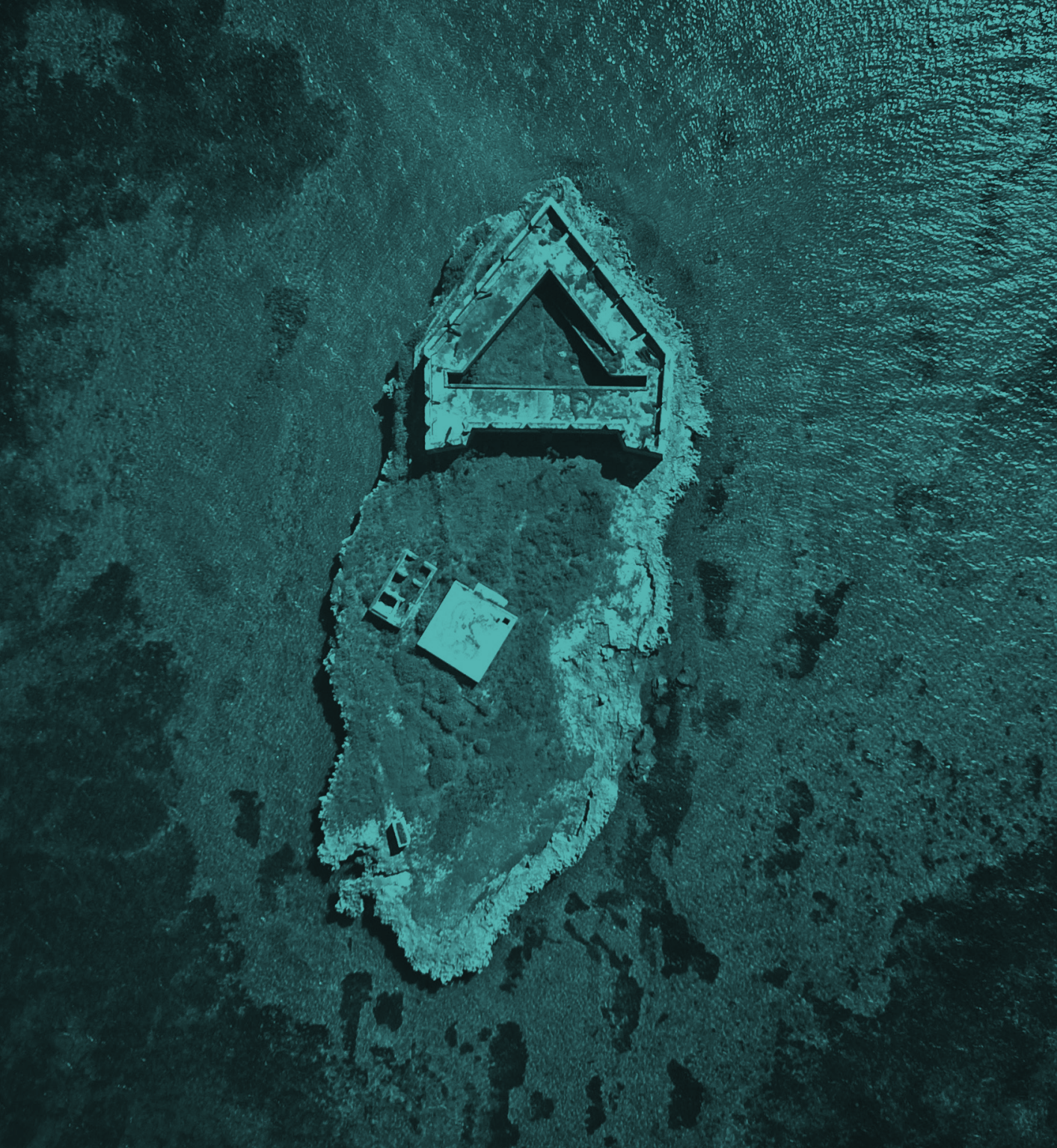




\section{EXPOSIÇÃO}

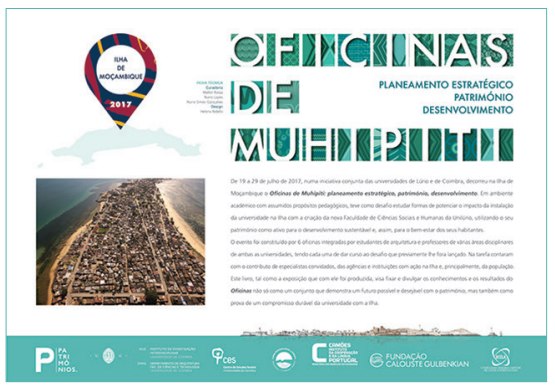

ESTRATÉGIAS

PARA O DESENVOLVIMENTO

SUSTENTADO

Professores

Margarida Relvão Calmeiro | DARQ-UC

Valdemiro Aboo | FAPF-UL

Alunos

Abilio Arrissane | UL Alexandre Nhantumbo | UL Ana Cruz | UC Beatriz Santiago | UC Cláudio Monteiro | UL
FICHA TÉCNICA

Curadoria

Walter Rossa

Nuno Lopes

Nuno Simão Gonçalves

Design

Helena Rebelo
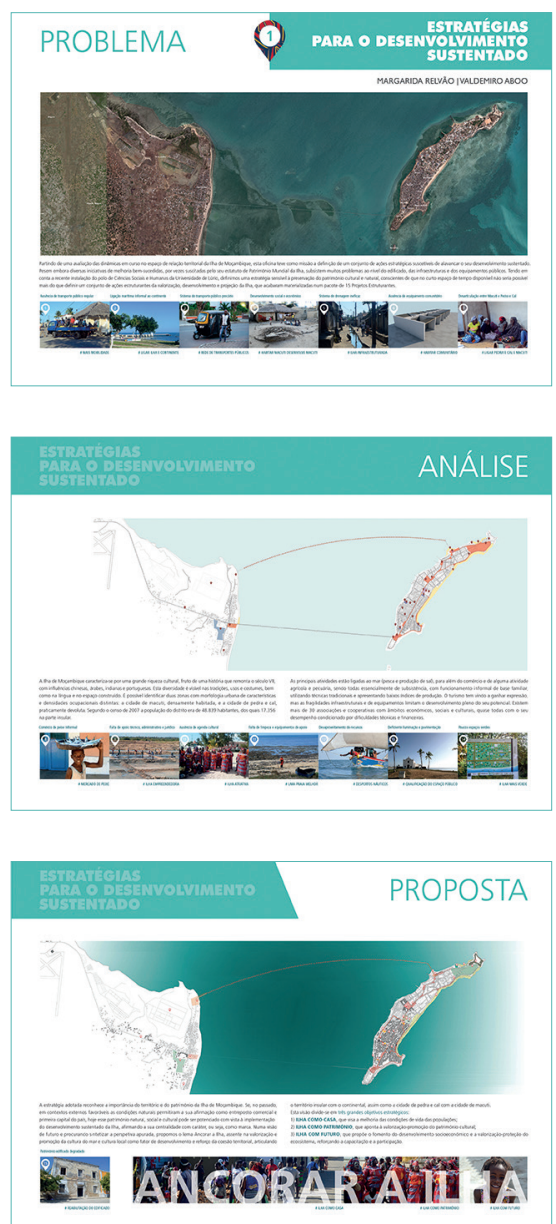

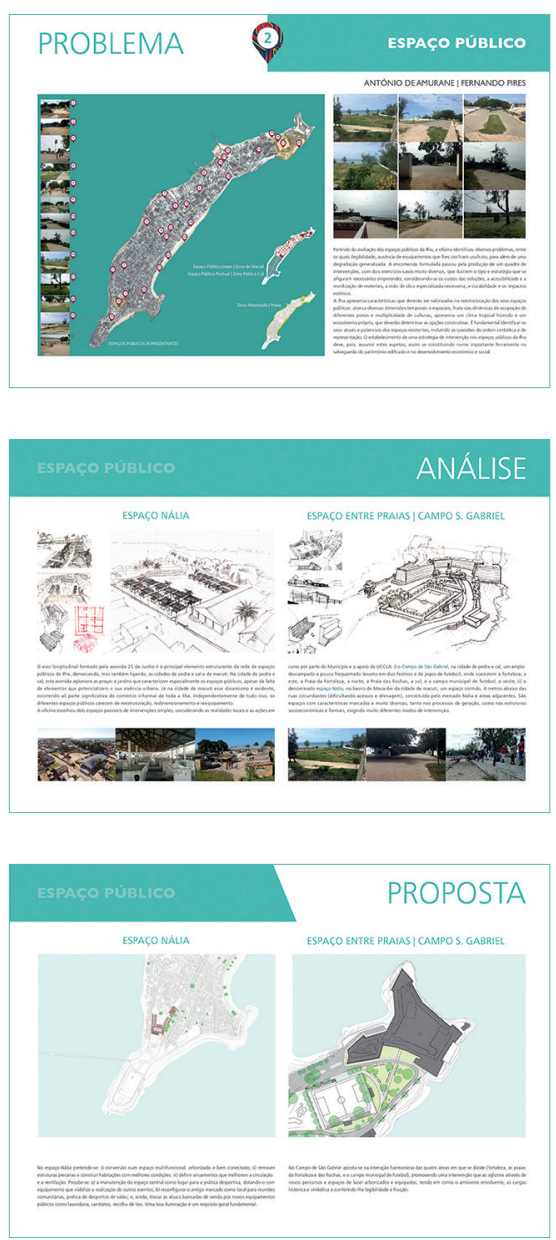

PLANO DIRETOR DA REFUNCIONALIZAÇÃO DA FORTALEZA

Professores Jaime Aguacheiro | FAPF-UL Nuno Lopes | PIP-UC Alunos Benildo Nobre | UL Inês Carreira | UC Joana Laranjeiro | UC Miguel Ferreira | UL Vagner Uissali | UL

\section{ESPAÇO PÚBLICO}

Professores

António Manuel de Amurane | FAPF-UL

Fernando Pires | PIP-UC

Alunos

Carlos Fraga | UC

Diogo Jorge | UC lara Vali | UL

Inês Lopes | UC Laize Lemos | UL Moyses da Costa | UL
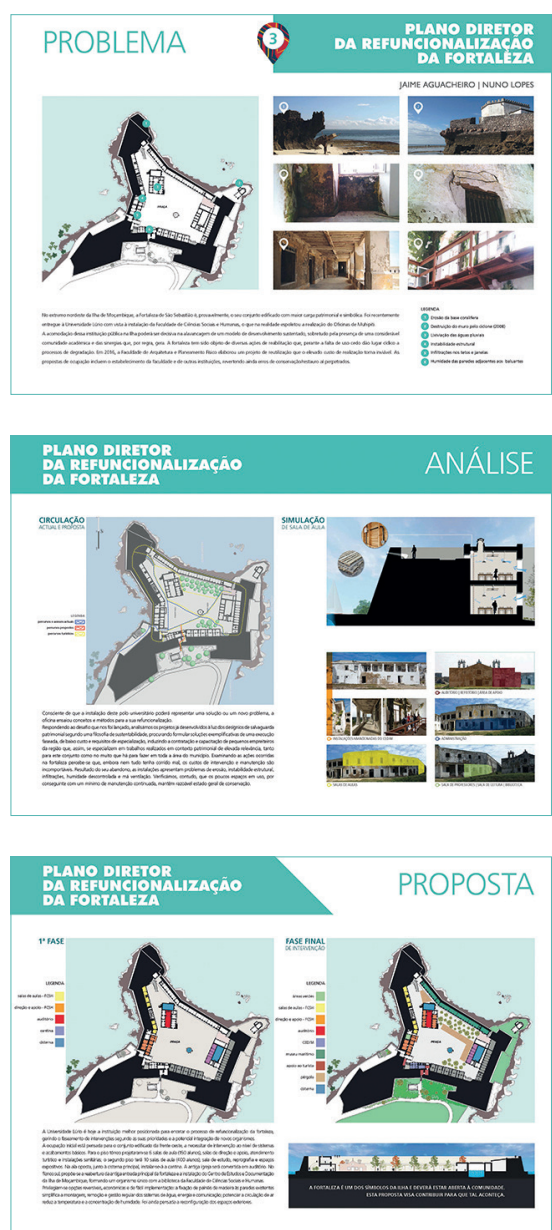

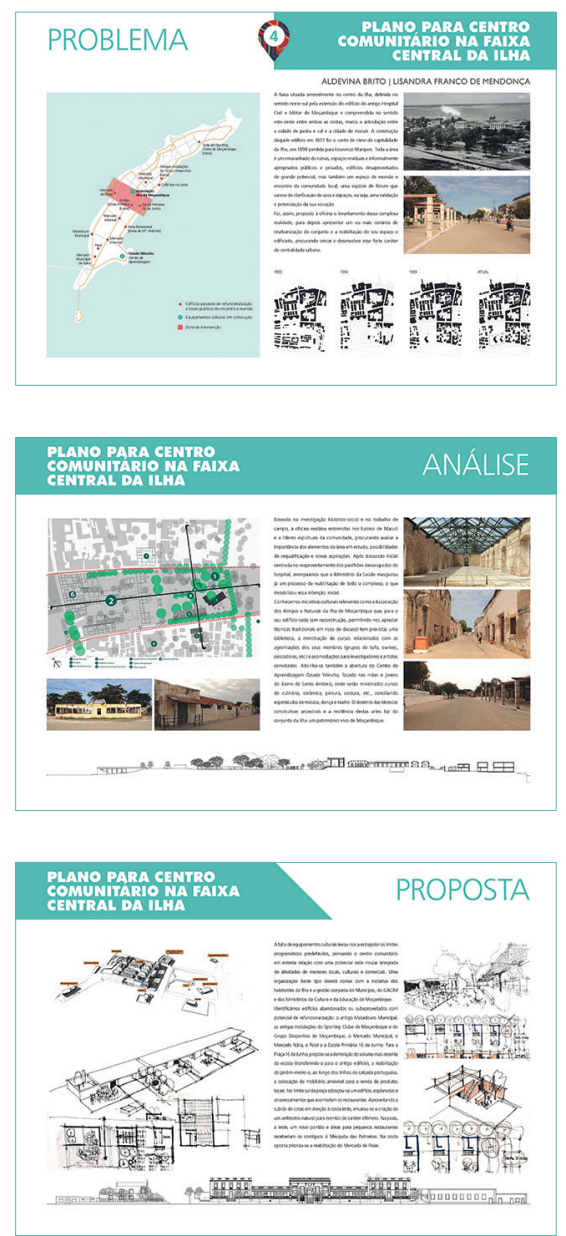

CASAS DE MACUTI

Professores Bernardo Xavier | FAPf-UL Victor Mestre | PIP-UC Alunos Abrão Gotine | UL Hipólito Rupavate | UL Jorge Tomo | UC José Ribau | UC Rito Saíde | UL
PLANO PARA CENTRO COMUNITÁRIO

NA FAIXA CENTRAL DA ILHA

Professores

Aldevina Brito | FAPF-UL

Lisandra Franco de Mendonça | PIP-UC

Alunos

Emanuel Barbito | UL

Filipe Muririua | UL

Francisco Paixão | UC

Inês Vilares | UC

Wilson Lodovivo | UL
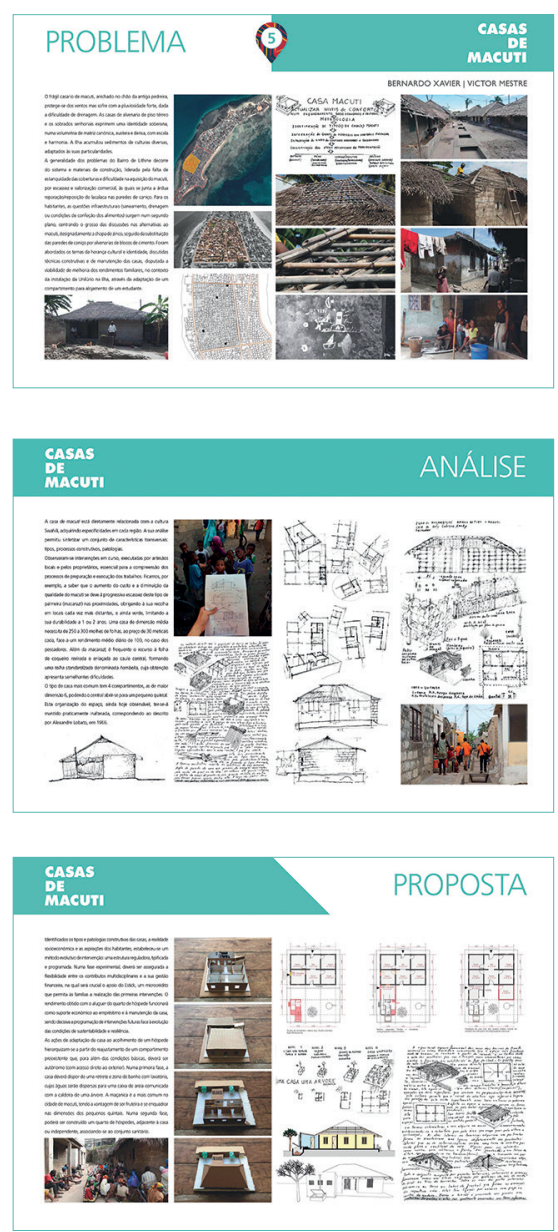

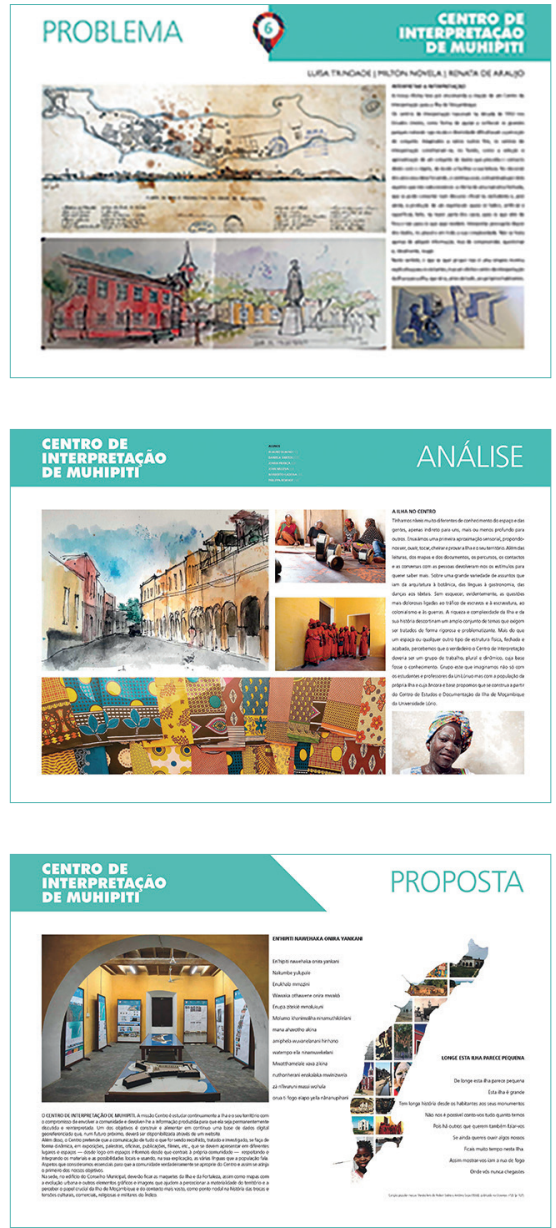

CENTRO DE INTERPRETAÇÃO

DE MUHIPITI

Professores

Luísa Trindade | PIP-UC

Milton Novela | FAPF-UL

Alunos

Blaund Blaund | UL

Daniela Santos | UC

Joana França | UC

John Muleva | UL

Norberto Cadeira | UL

Philippa Remhof | UC

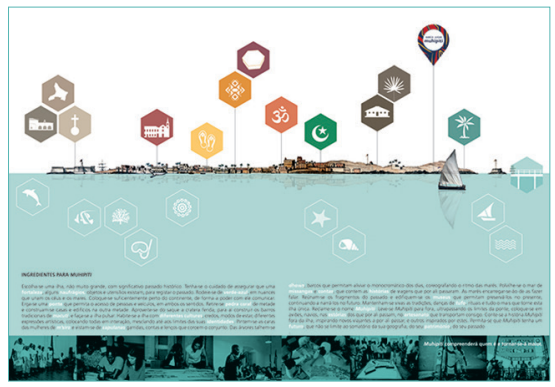




\section{MAQUETAS}

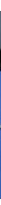

FICHA TÉCNICA | ILHA (1/1000)

Coordenação: Isequiel Alcolete e Walter Rossa | Projeto e execução: Nuno Gonçalves e Jorge Tomo Modelação laser: Nozzle, Lda. | Colaboração: Abílio Arrissane, Aldevina Brito, Alexandre Nhantumbo, Bernardo Xavier, Blaunde Blaunde, Carlos Fraga, Cláudio Monteiro, Emanuel Barbito, Francisco Paixão, Iara Vali, Inês Carreira, Jaime Aguacheiro, Joana Laranjeiro, Jone Muleva, José Esteves, Laize de Lemos, Miguel Ferreira, Milton Novela, Nuno Lopes, Philippa Remhof, Rito Amade, Vagner Uissali, Valdemiro Aboo e Wilson Ludovico.

\section{FICHA TÉCNICA | FORTALEZA (1/200)}

Coordenação: Isequiel Alcolete e Walter Rossa | Projeto e execução: Nuno Lopes e Inês Carreira Modelação laser: Nozzle, Lda. | Colaboração: Joana Laranjeiro e Jorge Tomo

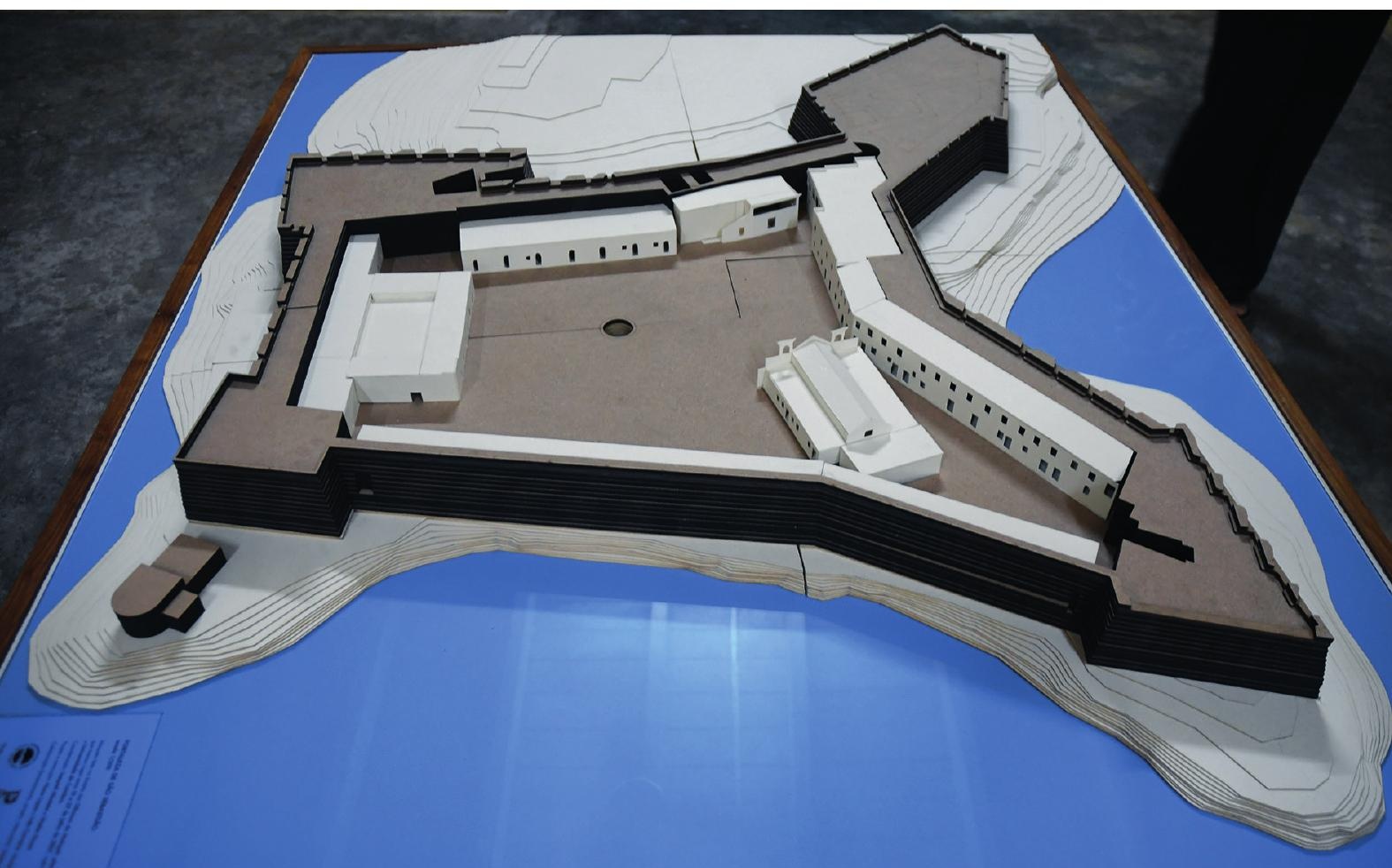




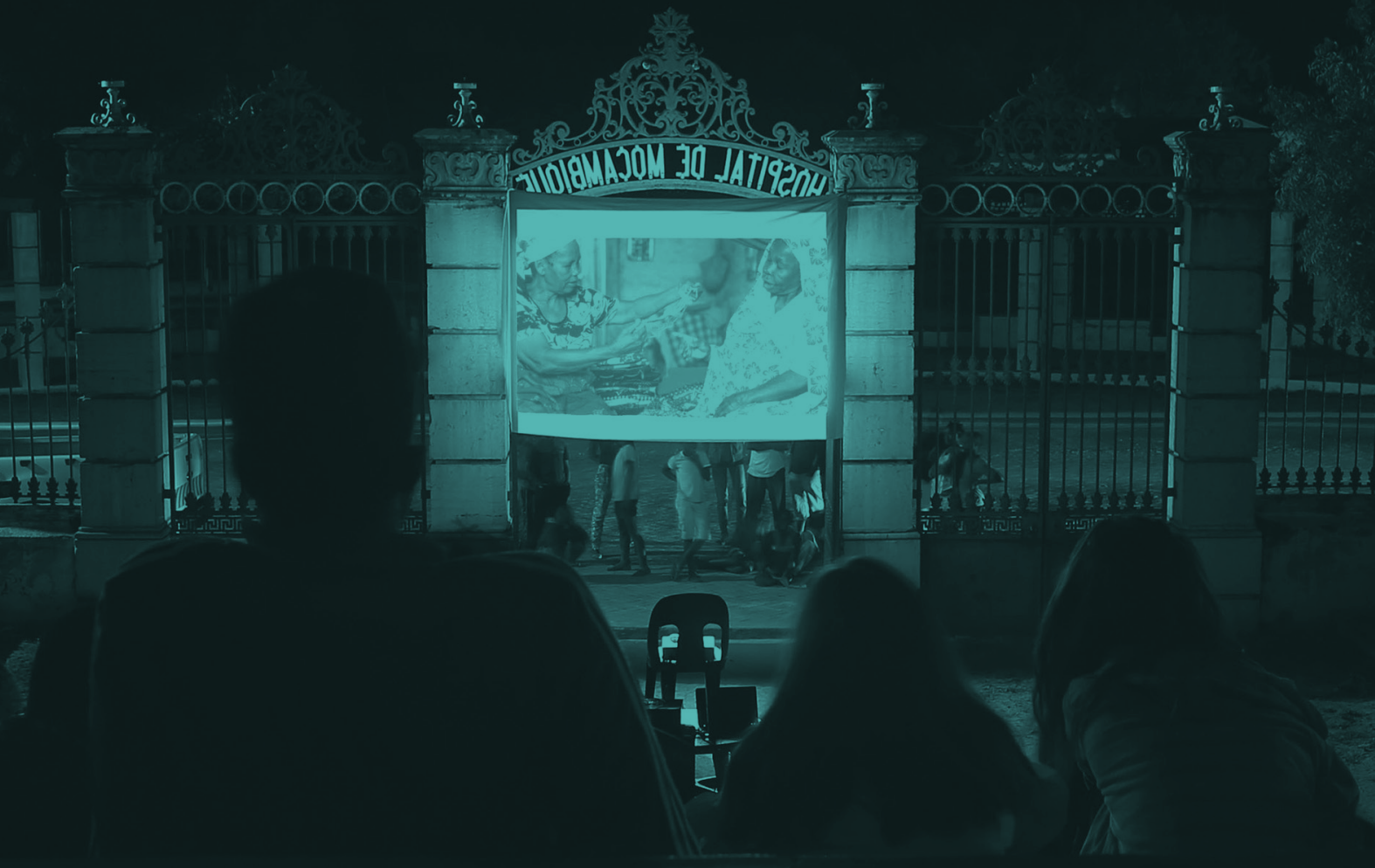




\section{DOCUMENTÁRIO}

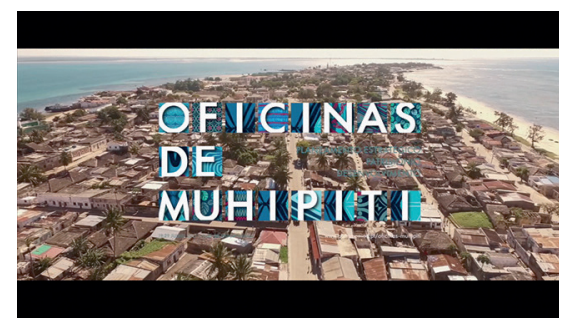

FICHA TÉCNICA

Realização, Imagem, Produção e Edição

Carlos Fraga

Francisco Paixão

Jorge Tomo Jr

José Ribau Esteves

(Departamento de Arquitetura da UC)

Pós-Produção José Ribau Esteves

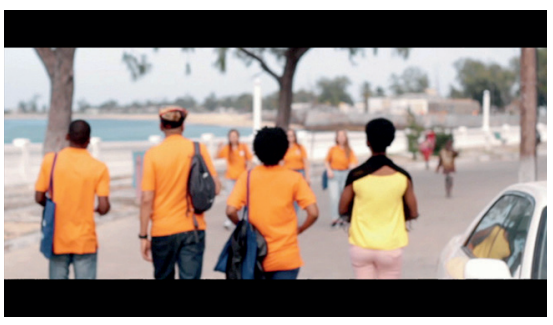

Música

Grupo Bayette, "Georgina", 1972

Tufo da llha

Duração

16 min e 9seg

Coimbra, 2018
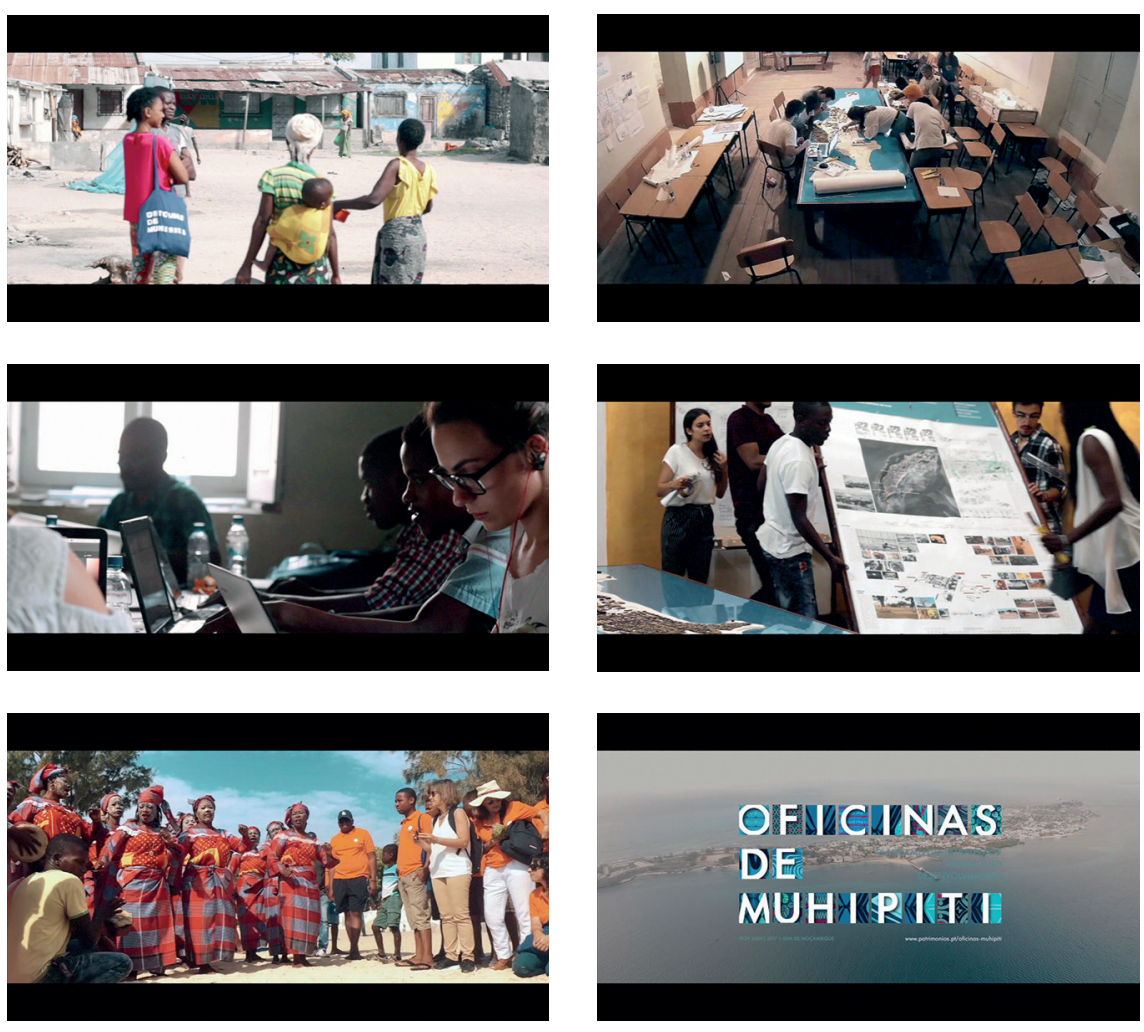

A Cátedra UNESCO em diálogo intercultural em Patrimónios de Influência Portuguesa (patrimonios.pt), agora instituída na Universidade de Coimbra, é a consumação temática e estratégica do projeto integrado de investigação e transferência de conhecimento assumida desde a criação do curso de doutoramento homónimo iniciado em 2010, através do Instituto de Investigação Interdisciplinar e do Centro de Estudos Sociais da Universidade de Coimbra.

Com uma matriz interdisciplinar, estuda e intervém sobre as heranças culturais das comunidades e dos territórios que sofreram influência das diásporas portuguesas, centrando-se no binómio de patrimónios vivos: paisagem e língua. Mobilizando contributos das áreas da arquitetura, urbanismo, estudos culturais, artes e história, estimula inquéritos multifacetados e multidisciplinares do património, interrogando-o como argumento e ação cultural e política, no passado como no presente, ou seja, encara-o como um ativo detentor de um potencial único para o desenvolvimento sustentável de sociedades prósperas e justas. 
(190) $c \cdot \frac{\mathrm{I}}{\mathrm{V}}$ 